Founder: Federal Scientific Center for Medical and Preventive Health Risk Management Technologies Federal Service for Surveillance on Consumer Rights Protection and Human Wellbeing

\section{Contact Information:}

82 Monastyrskaya St., Perm, 614045, Russia

Tel/Fax: +7 (342) 237-25-34

E-mail: journal@fcrisk.ru

Site: journal.fcrisk.ru/eng

Editor and corrector - M.N. Afanaseva

Technical Editor - M.M. Tsinker

Translators - N.V. Dubrovskaya,

N.A. Tregubova

All rights reserved. No part of this publication may be stored in the computer's memory or reproduced in any way without the prior written permission of the publisher.

The publication 30.12.2017.

Format 90×60/8.

Order No.343/2017.

Edition is 500 copies.

The price is free.

The Journal is registered by The Federal Service For Supervision Of Communications, Information Technology, And Mass Media (Roscomnadzor). Register certificate СМИ - ПИ No. ФС 77-52552

issued on January 21, 2013

Address of the publisher and printing house:

29 Komsomolsky ave., Perm, 614990,

Russia, tel.: +7 (342) 219-80-33

Printed by the Publishing House of Perm National Research Polytechnic University (29 Komsomolsky ave., Perm, 614990, Russia, tel.: +7 (342) 219-80-33)

\section{Subscription number:} catalog "Russian Post" ("Interregional subscription agency") 04153

ISSN (Print) 2308-1155

ISSN (Online) 2308-1163

ISSN (Eng-online) 2542-2308

\section{HEALTH RISK ANALYSIS}

Theoretical and practical journal. Start of publication: 2013.

EDITORIAL BOARD

4 issues per year

G.G. Onishchenko - Editor in Chief, Fellow of the Russian Academy of Sciences, DSc, Professor (Moscow, Russia)

N.V. Zaitseva - Deputy Chief Editor, Fellow of the Russian Academy of Sciences, DSc, Professor (Perm, Russia) I.V. May - Executive Secretary, DSc, Professor (Perm, Russia)

\section{EDITORS}

S.L. Avaliani - DSc, Professor (Moscow, Russia)

A.B. Bakirov - DSc, Professor (Ufa, Russia)

E.N. Belyaev - corresponding member of RAS, DSc, Professor

(Moscow, Russia)

V.M. Boev - DSc, Professor, (Orenburg, Russia)

I.V. Bragina -DSc (Moscow, Russia)

R.V. Buzinov - DSc (Arkhangelsk, Russia)

I.V. Bukhtiyarov - corresponding member of RAS, DSc,

Professor (Moscow, Russia)

V.B. Gurvich - DSc (Ekaterinburg, Russia)

I. Dardynskaia - DSc, Professor (Chicago, USA)

MA. Zemlyanova - DSc (Perm, Russia)

U.I. Kenesariev - DSc, Professor, corresponding member of the Academy of Medical Sciences of Kazakstan (Almaty, Kazakstan) T. Cronberg - DSc in Ec., DSc in Tec., Member of the European Parliament from Finland. (Ruveslahti, Finland) S.V. Kuz'min - DSc, Professor (Ekaterinburg, Russia)

V.V. Kutyrev - Fellow of the Russian Academy of Sciences, DSc, Professor (Saratov, Russia)

V.R. Kuchma - corresponding member of RAS, DSc, Professor, (Moscow, Russia)

A.V. Mel'tser - DSc, Professor (St.-Petersburg, Russia)

A.Ya. Perevalov - DSc, Professor (Perm, Russia)

Y.P. Pivovarov - Fellow of RAS, DSc, Professor

(Moscow, Russia)

A.Yu. Popova - DSc, Professor (Moscow, Russia)

V.N. Rakitskiy - Fellow of RAS, DSc, Professor, (Moscow, Russia)

S.I. Savelyev - DSc, Professor (Lipetsk, Russia)

P. Spencer - PhD, FRCPath Professor Department of neurology (Portland, USA)

V.F. Spirin - DSc, Professor (Saratov, Russia) Director

A.Tsakalof - Professor of Medical Chemistry (Larissa, Greece)

V.A. Tutelyan - Fellow ofRAS, DSc, Professor (Moscow, Russia)

H.H. Hamidulina - DSc, professor, (Moscow, Russia)

V.A. Horoshavin - DSc, professor, (Perm, Russia)

S.A. Hotimchenko - DSc, professor (Moscow, Russia)

L.M. Shevchuk - PhD (Minsk, Belarus)

N.V. Shestopalov-DSc, Professor (Moscow, Russia)

P.Z. Shur - DSc, professor (Perm, Russia)

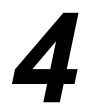

\section{October 2017 December}




\section{PREVENTIVE MEDICINE: URGENT ASPECTS OF RISK ANALYSIS}

N.V. Zaitseva, I.V. May, S.I. Sychik, E.V. Fedorenko, L.M. Shevchuk ANALYSIS OF LEGAL AND METHODOLOGICAL GROUNDS FOR RISK-ORIENTED SURVEILLANCE OVER CONSUMER PRODUCTS:

TASKS AND DEVELOPMENT PROSPECTS IN THE EURASIAN ECONOMIC UNION

SCIENTIFIC AND METHODICAL APPROACHES TO RISK ANALYSIS IN HYGIENE AND EPIDEMIOLOGY

V.F. Obesnyuk

BEWARE, PERSON-YEARS! EXPERIENCE OF SIMPSON PARADOX OBSERVATION IN EPIDEMIOLOGICAL RISK EXAMINATIONS

V.Yu. Smolensky, P.Z. Shur, D.V. Suvorov, O.I. Goleva, V.A. Safronov, E.V. Khrushcheva, I.V. Vindokurov

METHODOLOGICAL APPROACHES

TO ASSESSING ECONOMIC EFFECTS

OF ACTIVITIES AIMED AT MINIMIZING HEALTH RISKS RELATED TO EXTREMELY DANGEROUS INFECTIONS

RISK ASSESSMENT PRACTICE IN HYGIENIC AND EPIDEMIOLOGICAL STUDIES

S.F. Fomina, N.V. Stepanova NON-CARCINOGENIC RISK FOR CHILDREN POPULATION HEALTH IN KAZAN CAUSED BY FOOD PRODUCTS AND FOOD RAW MATERIALS CONTAMINATION

M.M. Vasileva, A.A. Popel, E.S. Yurkevich, I.I. Ilyukova

HYGIENIC ASSESSMENT OF RISK CAUSED BY APPLICATION OF GRAMINIS KE AND RINKOR VG HERBICIDES

E.G. Kobaidze, M.M. Padrul HIGH RISKS OF SOMATIC PATHOLOGY IN WOMEN WITH CHRONIC

N.Kh. Gafiatulina, L.V. Tarasenko, S.I. Samygin, S.Yu. Eliseeva SOCIAL HEALTH AND PERCEPTION OF RISKS BY STUDENTS LIVING IN SOUTHERN RUSSIAN REGIONS (BASED ON SOCIOLOGICAL QUESTIONING DATA OBTAINED IN ROSTOV-ON-DON)
ПРОФИЛАКТИЧЕСКАЯ МЕДИЦИНА: АКТУАЛЬНЫЕ АСПЕКТЫ АНАЛИЗА РИСКА ЗДОРОВЬЮ

4 Н.В. Зайцева, И.В. Май, С.И. Сычик, Е.В. Федоренко, Л.М. Шевчук ПРАВОВЫЕ И МЕТОДИЧЕСКИЕ АСПЕКТЫ РИСК-ОРИЕНТИРОВАННОГО НАДЗОРА ЗА ПРОДУКЦИЕЙ, ОБРАЩАЕМОЙ НА ПОТРЕБИТЕЛЬСКОМ РЫНКЕ: МЕЖДУНАРОДНЫЙ ОПЫТ И ПРАКТИКА ПРИМЕНЕНИЯ В ЕАЭС

НАУЧНО-МЕТОДИЧЕСКИЕ ПОДХОДЫ К АНАЛИЗУ РИСКА В ГИГИЕНЕ И ЭПИДЕМИОЛОГИИ

23 В.Ф. Обесенюк ОСТОРОЖНО, ЧЕЛОВЕКО-ГОДЫ! ОПЫТ НАБЛЮДЕНИЯ ПАРАДОКСА СИМПСОНА В ЭПИДЕМИОЛОГИЧЕСКИХ ИССЛЕДОВАНИЯХ РИСКА

32 В.Ю. Смоленский, П.З. Шур, Д.В. Суворов, О.И. Голева, В.А. Сафронов, Е.В. Хрущева, И.В. Виндокуров МЕТОДИЧЕСКИЕ ПОДХОДЫ К ОЦЕНКЕ ЭКОНОМИЧЕСКОГО ЭФФЕКТА МЕРОПРИЯТИЙ ПО МИНИМИЗАЦИИ РИСКА ЗДОРОВЬЮ, СВЯЗАННОГО С ОСОБО ОПАСНЫМИ ИНФЕКЦИЯМИ

ПРАКТИКА ОЦЕНКИ РИСКА В ГИГИЕНИЧЕСКИХ И ЭПИДЕМИОЛОГИЧЕСКИХ ИССЛЕДОВАНИЯХ

42 С.Ф. Фомина, Н.В. Степанова НЕКАНЦЕРОГЕННЫЙ РИСК ДЛЯ ЗДОРОВЬЯ ДЕТСКОГО НАСЕЛЕНИЯ Г. КАЗАНИ, ОБУСЛОВЛЕННЫЙ КОНТАМИНАЦИЕЙ ПИЩЕВЫХ ПРОДУКТОВ И СЫРЬЯ

49 М.М. Васильева, А.А. Попель, Е.С. Юркевич, И.И. Ильюкова ГИГИЕНИЧЕСКАЯ ОЦЕНКА РИСКА ПРИ ПРИМЕНЕНИИ ГЕРБИЦИДОВ ГРАМИНИС, КЭ И РИНКОР, ВГ

57 Е.Г. Кобаидзе, М.М. Падруль РИСКИ СОМАТИЧЕСКОЙ ПАТОЛОГИИ У ЖЕНЩИН С ХРОНИЧЕСКИМ ЭНДОМЕТРИТОМ

66 Н.Х. Гафиатулина, Л.В. Тарасенко, С.И. Самьгин, С.Ю. Елисеева СОЦИАЛЬНОЕ ЗДОРОВЬЕ И ВОСПРИЯТИЕ РИСКОВ СТУДЕНЧЕСКОЙ МОЛОДЕЖЬЮ ЮГА РОССИИ (НА МАТЕРИАЛАХ СОЦИОЛОГИЧЕСКОГО ОПРОСА В Г. РОСТОВ-НА-ДОНУ) 
MEDICAL AND BIOLOGICAL ASPECTS OF THE ASSESSMENT OF THE RISK FACTORS

V.A. Belyaeva INFLUENCE EXERTED BY RISK

FACTORS OF SPACE AND ERATH WEATHE ON FREQUENCY OF EMERGENCY CALLS FROM PATIENTS WITH ACUTE CEREBRAL CIRCULATION DISORDERS

HEALTH RISK MANAGEMENT IN OCCUPATIONAL MEDICINE

E.Ya. Titova, S.A. Golub' CONTEMPORARY PROBLEMS OF HEALTH PROTECTION FOR WORKERS EMPLOYED

AT A LARGE INDUSTRIAL ENTERPRISE AND WORKING UNDER OCCUPATIONAL HAZARDS

R.S. Rakhmanov, M.Kh. Alikberov, Z.A. Omarova FACTORS CAUSING RISKS OF CARIES EVOLVEMENT IN DENTAL SOLID TISSUES UNDER ACCLIMATIZATION

M.F. Vil'k, O.S. Yudaeva, V.A. Aksenov, V.M. Ponomarev, V.I. Apattsev, E.A. Sorokina, V.B. Prostomolotova, A.S. Kozlov, E.O. Latynin ANALYSIS OF HAZARDOUS WORK ENVIRONMENT FACTORS AT A TRAIN CONDUCTOR WORKPLACE

EXPERIMENTAL MODELS AND INSTRUMENTAL SURVEYS FOR RISK ASSESSMENT IN HYGIENE AND EPIDEMIOLOGY

R.A. Orujov, R.E. Dzhafarova CHANGES IN THE NERVOUS SYSTEM STATE AND PERIPHERAL BLOOD PARAMETERS UNDER BENZENE INTOXICATION DURING AN EXPERIMENT

P.V. Trusov, N.V. Zaitseva, V.M. Chigvintsev, D.V. Lanin MATHEMATICAL MODEL FOR DESCRIBING ANTI-VIRUS IMMUNE RESPONSE REGULATION ALLOWING FOR FUNCTIONAL DISORDERS IN A BODY SCIENTIFIC REVIEWS

V.A. Kaptsov, V.N. Deinego RISKS OF AGE RELATED MACULAR DEGENERATION AND LED LIGHTING

N.A. Lebedeva-Nesevrya, I.G. Zhdanova-Zaplesvichko, V.I. Rerke, A.O. Barg ALCOHOL CONSUMPTION AS A FACTOR CAUSING RISKS FOR POPULATION HEALTH (RUSSIAN RESEARCH REVIEW)
МЕДИКО-БИОЛОГИЧЕСКИЕ АСПЕКТЫ ОЦЕНКИ ВОЗДЕЙСТВИЯ ФАКТОРОВ РИСКА

76 В.А. Беляева ВЛИЯНИЕ ФАКТОРОВ РИСКА КОСМИЧЕСКОЙ И ЗЕМНОЙ ПОГОДЫ НА ЧАСТОТУ ВЫЗОВОВ СКОРОЙ МЕДИЦИНСКОЙ ПОМОЩИ К ПАЦИЕНТАМ С ОСТРЫМ НАРУШЕНИЕМ МОЗГОВОГО КРОВООБРАЩЕНИЯ

\section{ОЦЕНКА И УПРАВЛЕНИЕ РИСКАМИ} В МЕДИЦИНЕ ТРУДА

83 Е.Я. Титова, С.А. Голубь СОВРЕМЕННЫЕ ПРОБЛЕМЫ ОХРАНЫ ЗДОРОВЬЯ РАБОТНИКОВ КРУПНОГО ПРОМЫШЛЕННОГО ПРЕДПРИЯТИЯ, РАБОТАЮЩИХ В УСЛОВИЯХ ПРОФЕССИОНАЛЬНЫХ ВРЕДНОСТЕЙ

91 Р.С. Рахманов, М.Х. Аликберов, З.А. Омарова К ВОПРОСУ О ФАКТОРАХ РИСКА РАЗВИТИЯ КАРИЕСА ТВЕРДЫХ ТКАНЕЙ ЗУБОВ ПРИ АККЛИМАТИЗАЦИИ

97 М.Ф. Вильк, О.С. Юдаева, В.А. Аксёнов, В.М. Пономарев, В.И. Апатиев, Е.А. Сорокина, В.Б. Простомолотова, А.С. Козлов, Е.О. Латынин АНАЛИЗ ВРЕДНЫХ ПРОИЗВОДСТВЕННЫХ ФАКТОРОВ НА РАБОЧЕМ МЕСТЕ ПРОВОДНИКА ПАССАЖИРСКОГО ВАГОНА

ЭКСПЕРИМЕНТАЛЬНЫЕ МОДЕЛИ И ИНСТРУМЕНТАЛЬНЫЕ ИССЛЕДОВАНИЯ ДЛЯ ОЦЕНКИ РИСКА В ГИГИЕНЕ И ЭПИДЕМИОЛОГИИ

108 Р.А. Оруджов, Р.Э. Джафарова ИЗМЕНЕНИЕ СОСТОЯНИЯ НЕРВНОЙ СИСТЕМЫ И ПОКАЗАТЕЛЕЙ ПЕРИФЕРИЧЕСКОЙ КРОВИ НА ФОНЕ ИНТОКСИКАЦИИ БЕНЗОЛОМ В ЭКСПЕРИМЕНТЕ

117 П.В. Трусов, Н.В. Зайцева, В.М. Чигвинщев, Д.В. Ланин МАТЕМАТИЧЕСКАЯ МОДЕЛЬ ДЛЯ ОПИСАНИЯ РЕГУЛЯЦИИ ПРОТИВОВИРУСНОГО ИММУННОГО ОТВЕТА С УЧЕТОМ ФУНКЦИОНАЛЬНЫХ НАРУШЕНИЙ В ОРГАНИЗМЕ ЧЕЛОВЕКА

\section{АНАЛИТИЧЕСКИЕ ОБЗОРЫ}

129 В.А. Капиов, В.Н. Дейнего РИСКИ РАЗВИТИЯ ВОЗРАСТНОЙ МАКУЛЯРНОЙ ДЕГЕНЕРАЦИИ И СВЕТОДИОДНОЕ ОСВЕЩЕНИЕ

147 Н.А. Лебедева-Несевря, И.Г. Жданова-Заплесвичко, В.И. Рерке, А.О. Барг ПОТРЕБЛЕНИЕ АЛКОГОЛЯ КАК ФАКТОР РИСКА ЗДОРОВЬЮ НАСЕЛЕНИЯ (ОБЗОР РОССИЙСКИХ ИССЛЕДОВАНИЙ) 
UDC 614.447.6-027.45-004.413.4 (4) (476)

DOI: $10.21668 /$ health.risk/2017.4.01.eng

\title{
ANALYSIS OF LEGAL AND METHODOLOGICAL GROUNDS FOR RISK-ORIENTED SURVEILLANCE OVER CONSUMER PRODUCTS: TASKS AND DEVELOPMENT PROSPECTS IN THE EURASIAN ECONOMIC UNION*
}

\author{
N.V. Zaitseva ${ }^{1}$, I.V. May ${ }^{1}$, S.I. Sychik ${ }^{2}$, E.V. Fedorenko ${ }^{2}$, L.M. Shevchuk ${ }^{2}$ \\ ${ }^{1}$ Federal Scientific Center for Medical and Preventive Health Risk Management Technologies, 82 Monastyrskaya \\ Str., Perm, 614045, Russian Federation \\ ${ }^{2}$ Scientific-practical Hygiene Center, 8 Akademicheskaya Str., Minsk, 220012, Republic of Belarus
}

The paper dwells on basic legal and sub-legislative documents issued in the EU, the USA, Canada, by the WTO and Codex Alimentarius Commission which provide control of consumer products safety on the basis of assessing risks for consumers' life and health. Risk-oriented surveillance is shown as a system which makes for lower loads on business but still provides systemic control over most hazardous products. The EU legislation fixes the right to perform supranational control over state control systems existing in the EU member states in terms of their relevance and legitimacy. This supranational control is supported by organizational structures and regulatory and methodological documents. National control systems are systematically reviewed and analyzed in order to secure their conformity to supranational regulatory acts, to detect any cases of noncompliance, and to spread the best practices. Risk analysis reviews and results are open and discussable. As a result of products hazards assessment their turnover can be limited, or they can be withdrawn from the market, or additional information on hazards or risks they may cause is to be provided for consumers. Public and constantly operating systems of informing about hazardous goods are well-developed. International experience and practices in the sphere of risk-oriented surveillance over consumer products can be and should be applied in the Eurasian Economic Union (EEU) countries.

The Eurasian Economic Union countries fix orientation at observing consumer goods safety principles in their legislation. There are also legal grounds for and practices in the sphere of risk-oriented approach to products manufactures. But it is necessary to further develop a products classification system as per consumer health risk parameters. And this task requires working out unified approaches to classification of both eatable and non-eatable products. It seems relevant to develop a public analytical database of risk-oriented control created with the use of the control and surveillance activities results obtained in the EEU countries. All the involved parties should more actively interact and exchange information on issues of products risks assessment as it is a vital component required for further development of the system.

Key words: consumer products, products risks assessment, risk-oriented surveillance, legislative basis, methodological approaches.

(C) Zaitseva N.V., May I.V., Sychik S.I., Fedorenko E.V., Shevchuk L.M., 2017

Nina V. Zaitseva - Academician of the Russian Academy of Sciences, Doctor of Medicine, Professor, Director (e-mail: znv@,fcrisk.ru; tel.: +7 (342) 237-25-34).

Irina V. May - Doctor of Biological Sciences, Professor, Deputy Director for Research (e-mail: may@fcrisk.ru; tel.: +7 (342) 237-25-47).

Sergei I. Sychik - Candidate of Medicine, Associate Professor, Director (e-mail: rspch@rspch.by; tel. +375 (17) 28-413-70).

Ekaterina V. Fedorenko - Candidate of Medicine, Associate Professor, Deputy Director for practical and sanitary-epidemiological supervision and work with EEC (e-mail: afedorenko71@mail.ru; tel. +375 (17) 28-41365).

Larisa M. Shevchuk - Candidate of Medical Sciences, Associate Professor, Deputy Director for Research (email: SheuchukLM@mail.ru; tel. +375 (17) 29-250-15).

* The research was performed duevti funancial support by EEC within the research work No H-17/197 
Creation of the Eurasian Economic Union (EAEU) and formation of the Single Economic Space presuppose the elimination of unnecessary state barriers that hamper free trade in the territories of the Union member countries. Economic integration is the leading motive of the Eurasian project, its main driving force [11]. To date, the sales turnover between the EAEU member states amounts to more than 43 billion US dollars $(14.2 \%$ of the total trade volume of the EAEU countries) ${ }^{1}$. The share of consumer goods in 2016 amounted to about $25.7 \%$ in value terms (food products: 13.0\%, non-food: $12.7 \%)$. Based on mutual trade, products of animal and vegetable origin (meat, fish, meat products, meat by-products, vegetables, fruits, cereals, products of flour-andcereals industry) come to the common market; fats and oils of vegetable and animal origin; sugar and confectionery; alcoholic and non-alcoholic beverages; soaps, detergents; perfumery and cosmetics; fabrics, carpets, clothes, shoes, toys, furniture, etc.

At the same time, we gained facts that testify to the cases of harm to consumers' health due to unsafe products traded on the market of the single economic space $[5-7,10,12]$. Since public health protection is the priority of any EAEU member state, development of the fundamentally new approaches to control safety of the consumer products, when circulating in the market, and to assessing their compliance with the legally established sanitary and epidemiological requirements, seems relevant.

For the Eurasian Economic Union, where state surveillance systems in the context of sanitary and epidemiological wellbeing are independent ${ }^{2}$, the elaboration of common methodological approaches to developing, approving, modifying and applying the common sanitaryepidemiological and hygienic requirements for products, as well as to products control procedure and the selection of adequate measures of state regulation (coercion), is an extremely urgent task $[1,9]$. The solutions for such a problem would allow, with an improvement in overall product safety, to minimize contradictions and misunderstandings in assessing the results of control and surveillance activities by national regulators regarding products traded on the market of EAEU.

The EAEU basic documents consider products safety as "the absence of unacceptable risk associated with the potential of causing harm and (or) damage" ${ }^{3}$. The documents provisions require the subordinate regulatory-methodological and informational grounds for assessing and managing the risks of potential harm to the protected values in relation to consumer products for assessing and managing risks for consumers' life and health and their property interests.

\footnotetext{
${ }^{1}$ On the results of foreign trade in goods of the Eurasian Economic Union. January - December 2016: analytical review of the Eurasian Economic Commission. Available at: http://www.eurasiancommission.org/ ru/act/integr_i_makroec/dep_stat/tradestat/analytics/Documents/Analytics_E_201612_180.pdf (28.08.2017).

${ }^{2}$ Treaty on the Eurasian Economic Union in the wording of 08.05 .2015 with amend. and alterations.ddt. 12.08.2017. Section X, Art. 51 "General principles of technical regulation". Available at: http://www.consultant.ru/document/cons

doc_LAW_163855/ef821de674bd00be353bb7b3efffdb453736d1f0/ (14.08.2017).

${ }^{3}$ Treaty on the Eurasian Economic Union in the wording of 08.05 .2015 with amend. and alterations.ddt. 12.08.2017. Appendix No. 9 "Protocol on technical regulation within the framework of the Eurasian Economic Union". Available at: http://www.consultant.ru/document/cons doc LAW 163855/d4a8ed9c96e6b5519b558f85f72112 ed06b1e527/ (12.08.2017).
} 
To date, all the EAEU member states legislatively ensured the transition to a risk-oriented state surveillance, and in particular, in the sphere of ensuring sanitary and epidemiological wellbeing and protection of consumers' rights. However, the implementation of models in most countries is in the stage of formation and accumulating data for assessing the efficiency and viability [3, 9]. In addition, the risk-oriented approaches in the organization of surveillance are meant to justify the frequency and scope of auditing legal entities and/or individual entrepreneurs' activities, rather than products as such already released onto the market.

Within this framework, an experience in the field of risk-oriented surveillance of products safety in the member states of the European Union, the United States, Canada, some individual Eurasian Economic Union member states and such international organizations as the World Trade Organization and Codex Alimentarius Commission, etc. seemed to be of exceptional interest.

The purpose of the study is to analyze the legal and methodological grounds for functioning the risk-oriented model of control and surveillance activities in the European Union, the United States, Canada and the EAEU countries in terms of ensuring products safety as the basis for improving the system for assessing health risks to the population from consumer products traded on the common market of the Eurasian Economic Union.

Materials and methods. In the course of the study, we reviewed over 150 regulatory and non-mandatory legal acts of the European Union, the USA and Canada, about 40 methodical documents of the Eu- ropean Union, the USA and Canada; about 30 normative and methodical acts of the EAEU member states (the Republic of Belarus, the Republic of Kazakhstan, the Republic of Kyrgyzstan, the Republic of Armenia, Russian Federation). Approximately 30 documents of international organizations, including the World Trade Organization (WTO), Codex Alimentarius Commission, the Organization for Economic Cooperation and Development (OECD), the International Organization for Standardization (ISO), the European Committee for Standardization, and other international regulators in the field of consumer products.

Results and discussion. The European Union (EuroUnion, EU) as a unique and complex organization, which unites 28 states, due to the longer history than the EAEU history, can be considered as an object for studying the experience in many areas of economy, including product safety.

The EU common goods market consolidates about 500 million consumers and 21 million manufacturers of different forms and sizes ${ }^{4}$. One of the union intentions is to ensure free goods flow on the market and establishing high standards for safety, including for in relation to consumers. The EU represents all its Member States in the World Trade Organization (WTO) and, having legal personality, can be a party to international agreements.

The Europe equivalent for the Russian "control and surveillance activities in the products market is "market surveillance" and official controls/surveillance for food, feedstuff, plants $[2,15]$. The peculiarity of the surveillance organizational structure over products on the Euro-Union market is the controls and surveillance at the EU

\footnotetext{
${ }^{4}$ About the EU . European Union. Available at: https://europa.eu/european-union/about-eu/countries en (06.08.2017).
} 
level, and simultaneously at the national level of the member states by the authorized member states authorities. Another tool for risk management is obliging the products manufacturers and other market participants to ensure and prove safety of products and to inform about possible threats.

Ensuring product safety in the EU is built on three key elements: legislation, quick response system, and standards.

The basic legislative documents that regulate ensuring safety of life and health for people using any type and category of products in the European Union are the Directive 2001/95/EC (of the European Parliament and the General Product Safety Council - General Product Safety Directive $^{5}$ ), which is elaborated in the context of developing the Directive 92/59 EEC under the same name, Regulation (EC) $765 / 2008^{6}$ ) (as applied to non-food products), Regulation (EC) 882/2004 $4^{7}$ ) and Regulation (EU) $2017 / 625^{8}$ ((in respect to foodstuffs, feed and plants). The same documents define the powers of the surveillance bodies with regard to products, their rights and duties.

The Directive on general safety of products 2001/95/EC establishes that "safe product shall mean any product which, under normal and reasonably foreseeable conditions..., does not present any risk or only the minimum risks ... considered to be acceptable" (Art. 2, para. b). Since risk is considered as a criterion of safety, Article 1 of the Directive establishes a general principle stating that "... legislation should be based on a risk analysis". It is determined that risk assessment is based on the scientific evidence available, and should be carried out based on independence, objectivity, transparency and follow the principle of preventive measures, providing for preventive risk management until "more comprehensive risk assessment".

The main responsibility for product safety lies with the operators of economic activities. However, "The Member States must ensure compliance with food laws, monitor and verify that the relevant requirements of food law are met by operators of economic activities in the production of food and feedstuff at all stages of production, processing and marketing" (Article 17 (2)).

The Directive authorizes national bodies to independently monitor the market and take actions against hazardous products through the designated national authorities.

The national authorities of the European Union countries that exercise monitoring and surveillance over the products market have the powers to control all products before and after their release; on

\footnotetext{
${ }^{5}$ General Product Safety. Directive (GPSD) 2001/95/EC. European Commission. Available at: https://ec.europa.eu/growth/single-market/european-standards/harmonised-standards/general-product-safety en (06.08.2017).

${ }^{6}$ Regulation (EC) No 765/2008 of the European Parliament and of the Council of 9 July 2008 setting out the requirements for accreditation and market surveillance relating to the marketing of products and repealing Regulation (EEC) No 339/93 (Text with EEA relevance). EUR-Lex: Access to European Union law. Available at: http://eurlex.europa.eu/legal-content/EN/TXT/?uri=CELEX:32008R0765 (06.08.2017).

${ }^{7}$ Regulation (EC) No 882/2004 of the European Parliament and of the Council of 29 April 2004 on official controls performed to ensure the verification of compliance with feed and food law, animal health and animal welfare rules. EUR-Lex: Access to European Union law. Available at: http://eur-lex.europa.eu/legalcontent/EN/ALL/?uri=CELEX\%3A32004R0882 (06.08.2017).

${ }^{8}$ REGULATIONS: Regulation (EU) 2017/625 of the European Parliament and of the Council of 15 March 2017. Official Journal of the European Union, 2017. Available at: http://eur-lex.europa.eu/legal-content/EN/TXT/PDF/?uri= CELEX:32017R0625\&from=EN (08.08.2017).
} 
the procedure for determining safety of any product, which may represent even minimal risks [13, 14, 16-18]. They check whether the goods available on the market are safe, ensure that the product safety laws and regulations are respected by manufacturers and other market participants, and apply sanctions when necessary.

It is extremely important that the Directive 2001/95/EC states that "conformity of a product with the criteria designed to ensure the general safety requirement shall not bar... from taking appropriate measures to impose restrictions on its being placed on the market, or to require its withdrawal from the market or recall where there is evidence that, despite such conformity, it is dangerous"(Art. 3, para. 5). Consequently, it is recognized that a situation where, in observance of all the requirements and standards, products under real conditions of use can be dangerous for life and health of a consumer.

Surveillance authorities warn potential consumers about dangerous products and encourage voluntary withdrawal of products from the market by their manufacturers, when they discover hidden risks.

The document accents to the importance of cooperation between the control bodies of the member states, including risk assessment, joint product auditing, exchange of competencies and scientific knowledge, implementation of joint projects for surveillance, tracing, withdrawal or recall of hazardous products. The European Commission (EC) as an executive body of the European Union is instructed to "promote and take part in the operation in a European network of the Member States authorities competent for product safety, in particular in the form of administrative cooperation" (Art. 10, para. 1).

It should be noted that the Directive 2001/95/EC, without establishing unambiguously the criteria for acceptable risk, operates with the notion of "serious risk", which refers to a risk requiring rapid intervention by public authorities, including those the effects of which are not immediate, requiring rapid intervention by the public authorities (para. d, Art. 2).

Adopted in April 2004, the EU Regulation No. $882 / 2004^{9}$ on the official control of compliance with the legislation in the field of food and feedstuffs established for the first time a risk-oriented approach to control, and Regulation 2017/625) ${ }^{10}$ broadened the application thereof [18]. The documents establish:

- the risk-oriented approach assumes that the load on business representatives is minimized, the control focuses on high-risk objects. When planning monitoring activities, reports on past audits of the objects under surveillance should be taken into account. In doing so, the competent authorities, in carrying out control activities and revising their periodicity, should consider the likelihood that consumers may be misled about the properties, quality, composition or country of origin of the products they purchase;

- transparency of official control is focused on increasing the responsibility of the surveillance authorities. The document provides for the possibility to publish the control results and establish ratings;

\footnotetext{
${ }^{9}$ Legislation on official controls. European Commission: Food. Available at: https://ec.europa.eu/food/safety/official_controls/legislation_en (05.09.2017).

${ }^{10}$ REGULATIONS: Regulation (EU) 2017/625 of the European Parliament and of the Council of 15 March 2017. Official Journal of the European Union, 2017. Available at: http://eur-lex.europa.eu/legal-content/EN/TXT/PDF/ ?uri=CELEX:32017R0625\&from=EN (08.08.2017).
} 
- foundation of reference laboratories and centers in those sectors where there is a need to create uniform, comparable methods for analysis, testing and diagnostics;

- explanation of selection, analysis, testing, interpretation of results implies close interaction between supervising and supervised organizations in order to explain to the auditees the methods of sampling, analysis, testing, diagnosis and interpretation of the results obtained.

The European Commission ensures the development and control over the observance of clear and uniform rules applicable to food and non-food products. Its tasks are to facilitate infrastructure, organization, legal authority, etc. to be proper enough to ensure market surveillance in compliance with the law, in order to improve, including simplification, market surveillance procedures and product control in the EU and at its borders; to develop tools for coordinating the activities of national surveillance bodies (for example, discussion forums, databases and general market surveillance campaigns).

Another objective of the European Commission is to promote the implementation of the market surveillance structure and to ensure its effectiveness at national levels.

A special condition for the successful operation of product safety control and rapid response to risks, the EU documents determine the availability of rapid warning systems. There are several such systems in the European Union: Rapid Exchange of Information System (RAPEX), Rapid Alert System for Food and Feed (RASFF), Trade Control and Expert System (TRACES) and several others.

For example, RAPEX computer system is designed for rapid exchange of information between the member states and the European Commission on serious nonfood products risks for consumers (except for drugs, chemicals and medical equipment). The system accumulates data on hazardous products, on risk assessment, on control tests methods and their results, on other aspects that should be taken into account in monitoring activities, sharing knowledge and best practices. In addition to the above, the information that enables identifying products, the nature and duration of measures or actions taken is subject to disclosure.

This is an intensively developing system. For instance, since China is the largest source of imports of goods to the EU today, the European Union in collaboration with General Administration of Quality Supervision, Inspection and Quarantine of the People's Republic of China-AQSIQ) establishes RAPEX-China system for the exchange of information between the European Commission and AQSIQ on dangerous consumer goods of Chinese origin found in the EU. Bilateral cooperation with AQSIQ is complemented by tripartite cooperation with the U.S. Consumer Product Safety Commission involved.

Rapid Alert System for Food and Feed (RASFF) ensures rapid interaction between the national authorities of the EU member states responsible for food safety, which enables the authorities to promptly arrange withdrawal of unsafe food ${ }^{11}$. It is legally enshrined that the system should work twenty four - seven days a week ${ }^{12}$.

All EU member states submit reports to the European Commission with an assessment of market surveillance activities (by market sector), which allows for annual generalized analysis of effectiveness for system functioning and to justify measures to improve it [19].

In the United States, a country where the risk assessment methodology was implemented in legislation earlier than in other countries, a safety as "the absence of un- 
acceptable risk to life and health ..." is defined in the US Consumer Product Safety Improvement Act No. 4040, of $2008^{13}$ ).

The product safety issues based on risk assessment are governed by the National Technology Transfer and Advancement Act, 15 U.S.A. $\$ 3701$ et seq., 1996) ${ }^{14}$ and the Risk Assessment and Cost Benefit Act (RACBA), ddt. 23.02.1995 H.R. 1022 104$e p)^{15}$.

The Code of Federal Regulations of the USA contains legislative acts providing for the assessment of risks of food, cosmetic, chemical and other products, including the most sensitive groups, to the population health $^{16,17,18}$. Thus, the law on safety of food, drugs and cosmetics ${ }^{19}$ foresees health risk assessment, including the diseases associated with the mentioned goods in the process of their production and circulation on the market, as well as the establishment of quality standards based on risk assessment.

Compliance with standards is ensured by strict liabilities of producers, standardization and certification bodies. In addition to administrative penalties and damages caused by poor-quality goods, manufacturers can be enforced with punitive damages, aimed at preventing future violations, by court of law in favor of state's revenue. And the amount of such losses reaches hundreds of million dollars (for example, Snyder vs. American Association of Blood Banks precedent, in which the patient recovered \$11 million from the Association for contracting AIDS as a result of blood transfusions, which was tested in the laboratory of the Association [21]). The standardization and certification bodies that allowed low-quality products release into circulation may also be held liable for negligence and inadvertence.

In general, the US laws minimize legislative pressure on producers, makes a significant emphasis on informing the public at large, business communities and consumers about the risks of products, thereby guiding manufacturers to voluntarily assess and minimize product risks for the population life and health. At the same time, legislation fixes as a priority the system for controlling products safety at all stages of production as a guarantee for safety of

\footnotetext{
${ }^{11}$ Regulation (EC) No 178/2002 of the European Parliament and of the Council of 28 January 2002 laying down the general principles and requirements of food law, establishing the European Food Safety. Authority and laying down procedures in matters of food safety. EUR-Lex: Access to European Union law. Available at: http://eur-lex.europa.eu/legalcontent/EN/TXT/?uri=celex:32002R0178 (06.08.2017).

${ }^{12}$ Commission Regulation (EU) No 16/2011 of 10 January 2011: Laying down implementing measures for the Rapid alert system for food and feed. Official Journal ofthe European Communities, 2011. Available at: http://eurlex.europa.eu/legal-content/EN/TXT/PDF/?uri=OJ:L:2011:006:FULL\&from=EN (06.08.2017).

${ }^{13}$ Consumer Product Safety Improvement Act of 2008: Public Law 110-314, 110th Congress, 2008. Available at: https://www.cpsc.gov/s3fs-public/cpsia.pdf (06.08.2017).

${ }^{14}$ National Technology Transfer and Advancement Act of 1995: Public Law 104-113, 104th Congress, 1996 Available at: https://www.nist.gov/standardsgov/national-technology-transfer-and-advancement-act-1995 (06.08.2017).

${ }^{15}$ H.R.1022 - Risk Assessment and Cost-Benefit Act of 1995:/ 104th Congress (1995-1996). Congress.Gov. Available at: https://www.congress.gov/bill/104th-congress/house-bill/1022 (06.08.2017).

${ }^{16}$ Federal Food, Drug, and Cosmetic Act (FD\&C Act). U.S.Food and drug. Available at: https://www.fda.gov/RegulatoryInformation/LawsEnforcedbyFDA/FederalFoodDrugandCosmeticActFDCAct/ default.htm (06.08.2017).

${ }^{17}$ Toxic Substance Control Act (TSCA): Public Law 94-469, 94th U.S. Congress, 1976. Available at: https://www.govtrack.us/congress/bills/94/s3149/text/enr (дата обращения: 06.08.2017).

${ }^{18}$ Federal Hazardous Substances Act (Codified at 15 U.S.C. §§1261-1278), 2011. Available at: https://www.cpsc.gov/s3fs-public/fhsa.pdf (06.08.2017).

${ }^{19}$ CFR - Code of Federal Regulations. Title 21. Food and drugs chapter I - food and drug administration department of health and human services subchapter A. U.S. Food and Drug. Available at: https://www.accessdata.fda.gov/scripts/cdrh/cfdocs/cfCFR/CFRSearch.cfm?CFRPart=7\&showFR=1 (07.09.2017).
} 
goods at the "exit". And for children's toys, food and chemicals, there are mandatory requirements for compulsory risk assessment for life and health of consumers and risks reduction to acceptable levels.

The notion of a "significant risk" is used in the US regulatory framework. Three classes of risk "significance" (classes A, B, C) are based on two components: the severity of damage/illness and the likelihood of this damage occurrence. For example, the risk refers to " $\mathrm{A}$ " class if causing death or serious harm (illness) is probable or very likely; to "B"class, if the probability of death or serious harm is low, etc. The hazard assessment takes into account the following factors (but is not limited to):

- actually recorded cases of diseases or injuries associated with the use of a product;

- a product hazard assessment results for different population segments that will be exposed to the product in question, including the most sensitive groups;

- an assessment of the severity of potential harm to the health of populations at risk;

- an assessment of hazard occurrence probability;

- an assessment of immediate or delayed consequences of risk occurrence.

Based on the above factors analysis, surveillance authorities classify products into three classes ${ }^{19}$ with the aim of justifying the decisions on managing risks to consumers' health (Table 1).

For example, based upon results of assessing risks to children life and health, the US Consumer Product Safety Commission banned the sales of Neocub toys (mainly known in the US as Buckyballs or Nanodots).

In the United States, the cumulation of data on products non-compliance with the requirements of laws on safety is
Table 1

Classification of products to be withdrawn from the market taking into account level of hazard (risk) for the health of consumers

\begin{tabular}{|l|l|}
\hline Class & \multicolumn{1}{|c|}{ Explanation } \\
\hline Class A & $\begin{array}{l}\text { Products that are in violation of safety re- } \\
\text { quirements, when used, or when in contact } \\
\text { with, there is a likelihood of serious ad- } \\
\text { verse consequences for health or death of a } \\
\text { consumer. } \\
\text { Probable actions: withdrawal from the } \\
\text { market, products recall from purchasers }\end{array}$ \\
\hline Class B & $\begin{array}{l}\text { Products in violation of safety require- } \\
\text { ments, when used or when in contact with, } \\
\text { there is a likelihood of developing tempo- } \\
\text { rary or reversible long-term consequences } \\
\text { for consumers health, or a likelihood of } \\
\text { serious adverse health effects is remote. } \\
\text { Actions: withdrawal from the market }\end{array}$ \\
\hline Class C & $\begin{array}{l}\text { Products with safety breaches, when used } \\
\text { or when in contact with, there is a likeli- } \\
\text { hood of adverse effects on consumers' } \\
\text { health is minimal. } \\
\text { Actions: restriction of market release }\end{array}$ \\
\hline
\end{tabular}

mandatory. Since 2013, the updates on the project on implementing the methodology for assessing risks of imported consumer products are being accumulated. The program allows CPSC employees to analyze data provided by the US Customs Service and the Border Guard, and determine highrisk shipments of consumer goods entering the US ports and then to make reasonable and effective decisions on the selection of goods needed for verification. [20] In addition, such a program also allows you to recognize products of low risk level, but shipped together with consignments of high-risk products and prevent blocking low-risk products arrivals to the US market.

The specific experience in the riskoriented surveillance of consumer products safety was gained in Canada.

The system of state control over consumer goods safety in Canada is built upon 
principles of the priority to post-market approach. For manufacturers and sellers, there is no prior approval of the products safety authorities required to release products into market circulation. Under the Consumer Product Safety Act of Canada ${ }^{20}$, manufacturers are fully responsible for the fact that the consumer products they manufacture, import, sell or advertise in Canada do not pose a threat to human health or safety. In this case, according to the Art. 21-22 of the Act, a person authorized for surveillance activities over products safety at any appropriate time may exercise control in places, including transport, where a consumer product is manufactured, imported, packaged, stored, advertised, sold, labeled, inspected or transported.

State, through the creation of a specific Consumer Product Safety Program, concentrates its resources on controlling those types of products where the risks to consumers' health are high. The sources of information for risk assessment of products in operation of this program are the reports on incidents related to products from manufacturers or consumers; reports (e.g. on products recalls) of other countries, research results, information from health and safety professionals, mass media and other sources.

There are considered such factors, as

- how serious is the actual or potential harm to consumer health is?;

- is it prudent to attribute the damage, if any, to the use of a product?

- whether there were other incidents related to a product?;

- what is the age of a consumer whose health is damaged?
- whether a consumer was aware of the potential hazard?;

- whether a product that caused harm to health was new or already in use?;

- whether a product represented potential hazard to consumer health or likelihood of fatal outcome when it is used normally?;

- is a realization of harm to consumers health when using a product for other purposes ... etc. possible?

A risk in full compliance with the classical methodical approaches is measured by combining the severity of harm that a consumer product can cause with the likelihood of this harm occurrence. The severity of damage is determined using the scale of five levels: 1) insignificant, 2) moderate, 3) severe, 4) life threatening and 5) fatal. The probability of harm to the product user is determined using the scale of six levels: 1) extremely rare, 2) rare, 3) unusual, 4) random, 5) ordinary and 6) frequent.

The level of product risk is determined using a matrix that combines the severity of injury and its probability. Risk levels are defined as "very high", "high", "medium" and "low".

The risk profile allows you to determine the overall level of risk (very high, high, medium, low) for a consumer product or cosmetics.

The TBT Agreement and the Agreement on the Application of Sanitary and Phytosanitary Measures (SPS measures) have been adopted to ensure fair trade and safety of products traded on the market of the World Trade Organization member countries. The SPS Agreement regulates food trade issues, while the TBT Agree-

${ }^{20}$ Canada Consumer Product Safety Act (CCPSA). Government of Canada. Available at: https://www.canada.ca/en/health-canada/services/consumer-product-safety/legislation-guidelines/acts-regulations/canadaconsumer-product-safety-act.html (07.09.2017). 
ment covers all non-food items.

In the international context, sanitary measures include legislation covering all stages of food products life cycle (sampling, requirements for final product, packaging and labeling, directly aimed at ensuring food safety, etc.), requirements for inspection procedures and approval (i.e. for surveillance), as well as risk assessment methods ${ }^{21}$.

The main principles of SPS Agreement are the harmonization and scientific validity of the applied sanitary measures. Harmonization assumes the widest possible use of Codex Alimentarius Commission standards, as defined in Art. 3.1 of the Agreement. In the absence of such, and also if the sanitary measure is more rigid in comparison with the documents requirements of the said international organization, it should be based on the appropriate scientific justification (Article 3.3). The requirements for food products, consistent with the standards and recommendations of Codex Alimentarius Commission, without additional justification, are adopted as being in accordance with the provisions of the WTO Agreement on SPS measures (Article 3.2).

When implementing the WTO Agreement on SPS measures, the states ensure that sanitary measures (and, as it follows from the definition, surveillance over product when it is marketed, also refers to such) are based on human life or health risks assessment relevant to circumstances. At the same time, the risk assessment methods developed by the relevant international organizations, i.e. Codex Alimen- tarius Commission, should be used (Art. 5.1).

In cases where relevant scientific evidence is insufficient, a Member may provisionally adopt sanitary or phytosanitary measures on the basis of available pertinent information, including that from the relevant international organizations as well as from sanitary or phytosanitary measures applied by other Members (Article 5.7).

The basic element of protecting consumer health is an appropriate level of sanitary protection (Appropriate level of protection - ALOP). In fact, the appropriate level of protection is equivalent to the notion of "acceptable risk" (Annex A.5). According to international approaches, the appropriate level of sanitary protection associated with food safety is customary understood as an existing or forecasted number of diseases due to foodstuff contaminated with dangerous chemicals or biological agents. Achieving and maintaining the level of acceptable risk requires introduction and implementation of the integrated interagency activities aimed at managing hazards associated with food. It should be noted that market surveillance, including listing of priority products and consistence of control, is one of the tools to ensure sanitary and epidemic wellbeing of the population.

Upon accession to the WTO, both the Russian Federation and the Republic of Kazakhstan declared that sanitary measures would be scientifically justified using risk assessment with the international standards applied ${ }^{22,23}$.

\footnotetext{
${ }^{21}$ Agreement on the Application of Sanitary and Phytosanitary Measures. World Trade Organization. Available at: www.wto.org/english/docs e/legal e/15sps 01 e.htm (20.08.2017).

${ }^{22}$ Report of the Working Party on the Accession of the Russian Federation to the World Trade Organization. Available at: http://economy.gov.ru/minec/activity/sections/foreigneconomicactivity/wto/doc20120201 0017 (06.09.2017).

${ }_{23}$ Report of the Working Party on the Accession of the Republic of Kazakhstan to the World Trade Organization.Available at: http://online.zakon.kz/m/Document/?doc id=35955627 (25.08.2017).
} 
The TBT Agreement ${ }^{24}$, which regulates, among other things, the general approaches to ensuring safety of non-food products, determines that technical regulations should be developed, adopted and applied only to fulfill a legitimate objective - national safety requirements, prevention of deceptive practices, protection of human health or safety, animals or plant life or health, or the environment. At the same time, risks that would arise when such goals are not achieved should be taken into account. When assessing such risks, such factors as available scientific and technical information, related processing technology, or intended end-uses of products, etc. are taken into account (Article 2.2).

When carrying out the conformity assessment procedures, it is necessary to strive to obtain adequate confidence that products conform with the applicable technical regulations, or standards, taking into account the risks non-conformity would create (Article 5.1.2).

The above-mentioned further confirms relevance of justifying the principles of state market surveillance for products that are common to the state members of the EAEU on the basis of health risk assessment.

Within the framework of the WTO Council for Trade in Goods, the Committee on Sanitary and Phytosanitary Measures operates, which is responsible for all matters governed by the "SPS Agreement" (paragraphs 1 and 4 of the Article 12, "SPS-Measures Agreement"), including the development of a procedure to monitor the process of international harmonization and coordination of such ac- tivity with relevant international organizations.

The Codex Alimentarius Commission ensures the development of food standards using risk assessment methodology, in collaboration with the $\mathrm{WHO}$ - the procedures for a risk-based approach to controlling imported food products and risk management. Thus, the Codex Alimentarius Commission developed the fundamental documents for the assessment of product risk: Working principles for risk analysis for food safety for application by governments $\mathrm{CAC} / \mathrm{GL}$ 62-2007, Principles and guidelines for the conduct of microbiological risk assessment CAC/GL-30, Principles and guidelines for the conduct of microbiological risk management (MRM) CAC/GL 63-2007, Guidelines for risk analysis of foodborne antimicrobial resistance CAC/GL 77-2011, Guidelines for the design and implementation of national regulatory food safety assurance programme associated with the use of veterinary drugs in food producing animals CAC/GL 71-2009 and etc. ${ }^{25}$. The organization supports risk communication systems, considers various risk management options that can be used and combined to ensure product controlling based on risks and optimizing the use of available resources.

The Eurasian Economic Union countries, in full accordance with the world tendencies, are oriented towards the application of the methodology for assessing the risk of products during control of goods safety.

The EAEU system of technical regulation and sanitary and phytosanitary measures, both in general in developed countries and in international unions, con-

\footnotetext{
${ }^{24}$ WTO Agreement on Technical Barriers to Trade. World Trade Organization. Available at: https://www.wto.org/english/docs e/legal_e/17-tbt_e.htm (25.08.2017).

${ }^{25}$ Guidelines and Standards of the Codex Alimentarius Commission. Codex Alimentarius Commission. Available at: http://www.fao.org/fao-who-codexalimentarius/codex-texts/guidelines/en/ (02.09.2017).
} 
siders product safety as the absence of unacceptable risk.

The requirements of technical regulations and uniform sanitary requirements and standards (USRS) apply to all EAEU member countries that require development of methods and criteria for risk assessment based on common principles and approaches. To help the national regulators of the EEC, a methodological document "Methodology for assessing population health risks under exposure to chemical, physical, and biological factors to determine products (goods) safety parameters" was developed [4].

However, the supranational bodies of the EAEU function somewhat differently than, for example, in the EU. For instance, the Eurasian Economic Commission (EEC), as the EAEU regulating body, has the authority to develop EAEU policy in the field of product safety, but in comparison with the EU Commission, it has less control functions at the supranational level. Thus, EEC has no right to formally explain or interpret the regulations of the Union. The Commission does not play a decisive role in trade disputes arising between the EAEU member states, or between the EAEU and any third country. It has an extremely limited capacity for supervising the mandatory execution of the EAEU regulatory acts in the territory of the member states, including in particular the sanitary measures and technical regulation (for example, the control and surveillance and arbitration functions, the right to introduce quarantine, prohibitions and restrictions in trade, temporary SPS measures with regard to third parties). The EAEU also does not assume functioning of its own bodies and institutions for inspections, conformity assessment and risk assessment.

According to a number of researchers from WHO FAO, the absence of a centralized system for managing consumer product safety and general rules for national control systems in the EAEU results in decreasing safety assurance [8].

The product safety control functions are fully implemented at the national level. At the same time, as noted above, the riskoriented approach is enshrined in all EAEU member countries. At the same time, an analysis of the regulatory framework has shown that the risk-oriented model is formed and functions in terms of classification (categorization) of the risk of harm to the health of legal entities (LE), individual entrepreneurs (IE), or their types of activities.

For example, in Russian Federation, the risk-based surveillance is regulated by the Art. 8.1. of the Federal Law No. 294-FZ of December 26, 2008 "On Protection of Rights of Legal Entities and Individual Entrepreneurs in performing State Control (Surveillance) and Municipal Control" ${ }^{26}$. At the same time, "... a risk-oriented approach is a method of organization and implementation of state control (surveillance), in which the choice of intensity (form, duration, periodicity) of control measures, measures to prevent violation in mandatory requirements is determined by referring the activities of a legal entity, individual entrepreneur and (or) production facilities they use in performing such activity to a certain risk category or a certain class

\footnotetext{
${ }^{26}$ On Protection of Rights of Legal Entities and Individual Entrepreneurs in performing State Control (Surveillance) and Municipal Control: Federal Law No. 294-FZ of 26.12.2008 Available at: http://www.consultant.ru/document/cons_doc_LAW_83079/58672404e5897f38d20be06de33c4570c75d2897/ (07.09.2017).
} 
(category) of hazard". Depending on the activity category, as per risk of harm to health, the frequency of the planned control measures varies from once a year to once in seven years and less frequently.

In 2016, the Law of the Republic of Belarus "On Sanitary and Epidemiological Wellbeing of the Population" ${ }^{27}$ was amended to legislate the application of the risk-oriented approach while ensuring the sanitary and epidemiological wellbeing of the population, inter alia, at state sanitary and epidemiological regulation and state sanitary surveillance.

In the development of these changes, the Decisions of the Ministry of Health of the Republic of Belarus No. 8 ddt. January 20, 2017 "On Approval of the Instruction on the Procedure for Risk Analysis" were adopted $^{28}$, which determines the procedure for conducting risk analysis for the planning, organization and implementation of activities on ensuring sanitary and epidemiologic wellbeing of the population.

The document legislatively establishes three interrelated elements of risk analysis (risk assessment, risk management and risk communication), which meets international requirements, defines the competence of bodies and institutions that effect state sanitary surveillance, medical scientific organizations in implementation of risk analysis.

The document sets forth the procedure for assessing risks, managing risks and informing about the risks that are being performed by the authorized institutions, including collection and studying the neces- sary publicly available information; identification (detection) of the probability of adverse effects on human organism due to habitat factors, violations of legislation in the field of sanitary and epidemiological wellbeing of the population and the consequences of this exposure, leading to a threat to life and health of the population; an assessment of acceptability of the identified (detected) risks; justification, development and selection of optimal sanitary and anti-epidemic measures, adoption and implementation of the necessary measures to prevent and minimize risks; assessment of effectiveness and adjustment (if necessary) of the measures taken; monitoring risk levels; informing the involved parties about the risks, and risk management.

The risk-oriented approach to classifying the audited entities is enshrined in the Republic of Belarus by the Decree of the President of the Republic of Belarus No. 510 of October 16, 2009 "On improving control (surveillance) in the Republic of Belarus", which was modified significantly in October $2016^{29}$. The mentioned document specifies that a random audit is appointed taking into account the criteria for assessing risk level for the selection of the audited entities, and based on the analysis of the available information in hands of the surveillance authority that indicates a high risk of violations in the law and inability to detect and (or) eliminate them using other forms of state control (surveillance). The methodology for developing risk assessment system for the audited entities is be-

\footnotetext{
${ }^{27}$ On Sanitary and Epidemiological Wellbeing of the Population: the Law of the Republic of Belarus No.340-3 of January, 7, 2012 (in wording of 30.06.2016). Available at: http://www.pravo.by/main.aspx?guid=3961\&p0=C21600205 (07.09.2017).

${ }^{28}$ On Approval of the Instruction on the Procedure for Risk Analysis: the Decisions of the Ministry of Health of the Republic of Belarus No. 8 of January, 20 2017. Available at: http://www.pravo.by/document/?guid=12551\&p0=W21731770\&p1=1 (07.09.2017).

${ }^{29}$ On improving control (surveillance) in the Republic of Belarus: the Decree of the President of the Republic of Belarus of 16.10 .2009 No.510. Available at: http://president.gov.by/ru/official documents ru/view/ ukaz-376-ot-16-oktjabrja-2017-g-17324/ (07.09.2017).
} 
ing currently elaborated.

State control and surveillance in the Republic of Kazakhstan is performed in accordance with the Code of the Republic of Kazakhstan No. 375-V of October 29, 2015 "The Entrepreneurship Code of the Republic of Kazakhstan" ${ }^{30}$ (Chapter 13). Under the Article 141, the audited subjects (objects) are allocated by groups. The state control and surveillance takes into account the distribution of the audited entities into four groups.

In the context of ensuring sanitary and epidemiological wellbeing, risk assessment is performed taking into account the frequency and "violence degree" or "significance" of the violation in mandatory requirements. At the same time, the "extreme violence" refer to "... deliberate or reckless obvious and significant violations in the legislation of the Republic of Kazakhstan in the sphere of sanitary and epidemiological wellbeing of the population whose noncompliance has entailed and (or) may entail grave consequences for the population health", to "insignificant" - "violations in the requirements of the legislation of the Republic of Kazakhstan in the field of sanitary and epidemiological wellbeing of the population, the non-compliance of which entailed and (or) may entail the formally admitted, but not inflicted any tangible harm to the population". Other violations are considered "significant".

The categorization of products by risk level is not set forth legally.

In the Republic of Armenia, according to the latest version of the Law of the
Republic of Armenia "On Organizing and Conducting Audits in the Republic of Armenia" $^{131}$, all inspection bodies should implement risk-based audit systems and plan audits taking into account business entities risks levels (high risk level: once a year, average level of risk: less frequently than once in three years, and with a low risk level: no more than once every five years).

In the Kyrgyz Republic, all entities of entrepreneurship subject to audit, taking into account the magnitude of risk, fall into one of the three risk levels: high, medium, and insignificant. The assessment of the entity's compliance with the requirements of legislation is determined by applying the checklists in which questions are grouped according to the requirements therein:

"A"group: issues that contain requirements, the failure thereof directly causes/poses an immediate threat to human life and health safety;

"B" group: issues that contain requirements, the failure thereof does not create directly an immediate threat to human life and health safety.

The differentiated criteria have been developed for further risk assessment of the operations in various types of food products, the production and distribution of veterinary preparations, the harvesting, storage and marketing of feeds and feed additives (an example is given in Table 2).

Violations are given scores that are summed up. By the scores grand total, the audited subjects are classified to high, medium or insignificant risk groups.

\footnotetext{
${ }^{30}$ The Entrepreneurship Code of the Republic of Kazakhstan (as amended on 03.07.2017). Available at: http://online.zakon.kz/Document/?doc id=38259854 (07.09.2017).

${ }^{31}$ On Organizing and Conducting Audits in the Republic of Armenia: the Law of the Republic of Armenia of 17.05.2000 (as revised on 01.03.2017). Available at: http://www.parliament.am/legislation.php?sel=show\&ID= 1364\&lang=rus (07.09.2017).
} 
Table 2

Criteria for risk assessment in the production of milk and dairy products

\begin{tabular}{|c|c|c|}
\hline $\begin{array}{l}\text { Types } \\
\text { of violations }\end{array}$ & Criterion & $\begin{array}{l}\text { The number of identified } \\
\text { non-conformities to the } \\
\text { parameters contained } \\
\text { in checklists }\end{array}$ \\
\hline \multirow[t]{4}{*}{ Extreme } & Requirements for safety of milk and dairy products in their sales & 2 and more \\
\hline & $\begin{array}{l}\text { Requirements for safety of raw materials used for the production } \\
\text { (manufacture) of milk and dairy products }\end{array}$ & 6 and more \\
\hline & Requirements for safety of starter cultures and probiotic cultures & 2 and more \\
\hline & $\begin{array}{l}\text { Requirements for safety of milk and dairy products in their produc- } \\
\text { tion (manufacture) }\end{array}$ & 9 and more \\
\hline \multirow[t]{4}{*}{ Significant } & Requirements for safety of finished dairy products & 5 and more \\
\hline & $\begin{array}{l}\text { Requirements for safety of buildings, structures used in the produc- } \\
\text { tion (manufacture) of milk and dairy products }\end{array}$ & 4 and more \\
\hline & $\begin{array}{l}\text { Requirements for safety of milk and dairy products during storage } \\
\text { and transportation }\end{array}$ & 4 and more \\
\hline & Requirements for safety of milk and dairy products for disposal & 1 and more \\
\hline Insignificant & $\begin{array}{l}\text { Requirements for safety of packaging (tare) and labeling of milk } \\
\text { and dairy products }\end{array}$ & 3 and more \\
\hline
\end{tabular}

The categorization of products by the risk of harm to health is not in place.

In 2016, the Russian Federation Chief State Sanitary Doctor approved methodological guidelines "Classification of food products traded on the market by the risk of harm to consumers' health for the organization of routine control and surveillance activities" 32 . The document is designed to classify a particular type of product to one or another class for the risk of harm to health. The risk class (category) allows justifying the selection of priority products that must be audited during control and surveillance activities at storage facilities, food transportation, food trade and catering, as well as the frequency and scope of laboratory support for audits.

The potential risk of harm $(R)$ is considered as a consequence of violations in the requirements and standards established for certain types of food products by sanitary legislation and technical regulations, and is defined as the combination of violation probability in legal requirements for food safety, the severity of health damage due to consuming the unsafe food products, and the scope of potential consumption of these products:

$$
R=\sum_{i}\left(p_{i} u_{i}\right) W,
$$

where $p_{i}$ is the probability of violations of mandatory safety requirements for food products by the $i$-criterion (factor) during one inspection. As a hazard factor, we consider all the chemicals, microbiologicalparasitic agents, radiological indices, genetically modified organisms in products examined during the control and surveillance activities;

\footnotetext{
${ }^{32}$ On the Introduction of the Methodological Guidelines "Classification of food products traded on the market by the risk of harm to consumers' health for the organization of routine control and surveillance activities": Order of the Head of the Federal Service for Surveillance on Consumers Rights Protection and Human Wellbeing No. 16 of 18.01.2016. 2016, 34 p. Available at: http://rospotrebnadzor.ru/documents/details.php?ELEMENT_ID=5672 (07.09.2017)
} 
$u_{i}:$ relative harm to health, formed by violation of safety requirements to the $i$-th factor in a given product;

$W$ is a coefficient, characterizing regional features of food products consumption.

For each type of food product, the hazard identification (chemical, microbiological, parasitological, radiation) is done, probable types of health disorders that may occur in realization of these hazards is established. For each type of product, the relative harm to health associated with the violation of $i$-th factor is calculated as the sum of the regression coefficients weighted by the severity of diseases or death. The severity of diseases is assessed using WHO criteria.

For today it is the only methodical document in the countries of the EAEU, which allows classify products according to the risk parameters for consumer health. Approaches are universal, however, the calculations based on this methodology are performed only for Russia, since data on the frequency of violations and cases of harm to consumers' health are processed following the results of control and surveillance activities in Russian Federation over the past few years.

Conclusions. The analysis has shown that the experience of the European Union, the USA and Canada can and should be used for the tasks of improving the safety control systems for mutually supplied products traded on the consumer market of the Eurasian Economic Union.

The EAEU member states are committed to the ideas of risk-oriented surveillance and set it forth in supranational and national legislation. This situation can be considered as a favorable platform for developing a system of coordinated, mutually beneficial actions on products risk-oriented surveillance. Such a system would make it possi- ble to raise interstate relations to a new, substantially more trusting objective level, to actually put up barriers to products hazardous to public health, and to minimize administrative barriers for products that do not form serious risks to consumers' health losses in the entire unified economic space of the union.

The EAEU through a sufficiently deep and wide base of the sanitaryepidemiological requirements, standards, norms, enshrined in the technical regulations, provides a criterial background for product safety. The documents are oriented to assessing the health risk, which fully corresponds to the current trends. At the same time, the system of standards and norms is constantly being improved, also thanks to the initiative of all the stakeholders. At the same time, there are no uniform approaches to categorizing products by the potential risk of harming consumer health, which complicates the interaction of the parties in bringing the audits of goods entering the common market as a result of mutual trade.

Being the body responsible for the safety of consumer products in the EAEU, the EEC has a number of powers, including the development of the EAEU policy in this area. However, the basic legal and institutional problem is the lack of legislative formalization of an independent supranational control or monitoring over the mandatory observance of the EAEU regulatory acts on the territory of the member states. No powers formalized, which could be assigned to a supranational body to perform surveillance and arbitration functions, restrictions and bans on trade, temporary sanitary measures in respect of the third parties. As a consequence, all the ambiguous, sometimes conflict situations are resolved, as a rule, bilaterally between the EAEU member states. 
The all-union information and analytical base for the assessment of products risks to consumer health requires substantial development. The creation of a publicly accessible and transparent database to contain results of state control, surveillance and monitoring of products, and also cases of causing harm to health is a topical issue. It is advisable to improve the system of informational interaction on the history of state audits of goods in the event of damage to the health of consumers, complaints about certain types of products and goods.

Analysis of the statistics data on the state surveillance regarding product safety in Russia showed that approaches to the classification of consumer products, based on the principles of risk assessment as a combination of the probability of violation in mandatory sanitary requirements for products, the probability and severity of the consequences of these violations (taking into account the scopes of products consumption) can be replicated to the Eurasian Union as a whole. This will make it possible to create "risk profiles" for certain groups of goods and allocate products that can be characterized as "risky." The classification will allow controlling in a direct, targeted manner already at the first stages of introducing the risk-oriented surveillance.

The methodology of classifying products, as well as the model of risk-based surveillance, can function effectively if all its structural elements are present:

- the information surveillance base, which is a formalized, verified and structured data on the parameters of the products being audited; on the cases of violations in the mandatory requirements for products; on the consequences of these violations; on the evidence of the relation of health disorders with the product hazard factors;
- methodical, mathematical apparatus and software tools that allow information arrays processing: to obtain simple statistics on the results of control and surveillance activities (calculation of the frequency of violations in general, by types of products, factors, manufacturers, etc.), and also to perform more knowledge-intensive operations, i.e. to establish dependencies in the system "production - harm to human health"; "measures for risk management - a characteristic of product risk"; to estimate the average and maximum expected severity of health disorders, etc .;

- the organizational structure provided by trained personnel, whose functions include collecting, processing, analyzing data and informing all interested parties about the results;

- the established channels of information exchange, whereby some participants in the process transfer primary data to the system (control results, including laboratory research protocols, data on injuries, poisoning, diseases, complaints about products, etc.), and others, as a feedback, "announce" hazard or risk assessment results for any product. It is assumed that informing about risks should be gradually transformed into a more perfect form of data exchange - risk communication.

Realizing the potential for making any meaningful decisions within the framework of the Eurasian Union solely on the basis of consensus and political will of each individual state, one cannot fail to take into account that the optimal model for interaction between states and the internal strengthening of the union is the mutual movement towards an equal and mutually beneficial partnership. Such movement should be accompanied by an increase in mutual trust, including also by following the same principles in realizing the most important powers of states at the national level. 
In this regard, in order to increase effectiveness of measures to ensure the safety of products circulated in the single economic space of the EAEU (and risk-based surveillance is such a measure), in terms of improving the legislation of the Union, one could consider the issues of normative formalization at the EAEU level of the principles for organizing product safety control common for all member countries with further implementation of these principles into national legislation.

In such a situation, methodological guidelines on the risk-based surveillance, developed on the principles agreed upon by all parties, would have a much greater demand.

In the long term, taking into account the experience of the European Union, the EAEU can consider the possibility of creating a system of supranational independent audit, taking the advantages thereof will allow arbitration, objective resolution of two or multilateral conflicts arising in products circulation and surveillance, and at the same time will ensure the increasing authority of the EAEU as a coordinating body.

To ensure broad informational interaction between the stakeholders, it seems advisable to create a single information base on the background of the national product safety control systems, to accumulate a "history" of violations, create a bank of products risk "profiles" in terms of Customs Commodity Codes, risk factors, technologies and producing countries, at a later stages - manufacturing entities. It is assumed that the system will be created in the EAEU in the short term.

In order to continuously improve product risk management system, the annual analytical reports integrated in the framework of the EAEU, based on the results of state product safety surveillance, could be of doubtless interest, with issuing relevant guidelines to the authorized national bodies and setting tasks to scientific organizations.

\section{References}

1. Arnautov O.V. O sovershenstvovanii mekhanizmov ustanovleniya i izmeneniya pokazatelei kachestva i bezopasnosti pishchevoi produktsii v normativnykh i pravovykh aktakh Evraziiskogo Ekonomicheskogo Soyuza [On improvement of the mechanism for establishing and changing indicators of quality and food safety in the regulatory and legal acts of the Eurasian Economical Union]. Voprosy pitaniya, 2016, vol. 85, no. 1, pp. 110116 (in Russian).

2. Kuchinskaya L.V. Opyt kontrolya i nadzora za potrebitel'skim rynkom stran-uchastnits Evropeiskogo soyuza [Consumer market control and monitoring experience gained by eu countries]. Vestnik Rossiiskoi tamozhennoi akademii, 2010, no. 3, pp. 38-45 (in Russian).

3. Litvinova O.S. Bezopasnost' pishchevoi produktsii v Rossiiskoi Federatsii: retrospektivnyi analiz, perspektivy kontrolya na osnove risk-orientirovannogo podkhoda [Food safety in the russian federation. retrospective analysis, the prospects of control]. Zdorov'e naseleniya i sreda obitaniya, 2016, no. 10, pp. 32-35 (in Russian).

4. Metodologiya otsenki riskov zdorov'yu naseleniya pri vozdeistvii khimicheskikh, fizicheskikh i biologicheskikh faktorov dlya opredeleniya pokazatelei bezopasnosti produktsii (tovarov) [Methodology for assessing population health risks under exposure to chemical, physical, and biological factors to determine products (goods) safety parameters]. Moscow, Yumanite media, Publ., 2014, 120 p. (in Russian).

5. Murzashev M.N., Kozhogulova G.A. Epidemiologicheskaya situatsiya po pishchevym otravleniyam, v tom chisle po botulizmu v g. Bishkek [Epidemiological situation on food poisoning, including botulism in Bishkek]. Zdravookhranenie Kyrgyzstana, 2016, no. 3, pp. 38-40 (in Russian).

6. O sostoyanii sanitarno-epidemiologicheskogo blagopoluchiya naseleniya v Zabaikal'skom krae v 2016 godu: Doklad [On sanitary and epidemiologic welfare of the population in Zabaikalsk region in 2016: Report]. Upravlenie Federal'noi sluzhby po nadzoru v sfere zashchity prav potrebitelei i blagopoluchiya cheloveka po Zabaikal'skomu krayu, 2017, 224 p. (in Russian). 
7. Ryzhkov V.V., Kolupaev V.V., Efremov A.Yu. Issledovanie kharakternykh sluchaev pishchevykh otravlenii v molodezhnoi srede [Examination of typical food intoxications among young people]. Formirovanie issledovatel'skikh kompetentsii lichnosti didakticheskimi sredstvami: materialy nauch.-prakt. studench. konf. (Voronezh, 20 apr. 2017 g.) [Developing research competences of a person via didactic techniques: materials of theoretical and practical students' conference (Voronezh, 20 April 2017 2.)]. In: A.Yu. Efremov, I.F. Berezhnaya, M.D. Kniga, eds. Cheboksary, TsNS «Interaktiv plyus», Publ., 2017, pp. 177-180 (in Russian).

8. Sedik D., Ul'brikht K., Dzhamankulov N. Sistema kontrolya bezopasnosti pishchevoi produktsii v Evropeiskom Soyuze i Evraziiskom ekonomicheskom soyuze [Control system food safety in the European Union and the Eurasian Economic Union]. Torgovaya politika, 2016, no. 2 (6), pp. 41-83 (in Russian).

9. Fedorenko E.V. Pravovye osnovy primeneniya metodologii analiza riska pri obespechenii bezopasnosti pishchevoi produktsii v Evraziiskom ekonomicheskom soyuze i Respublike Belarus' [Legal basis for risk analysis methodology while ensuring food safety in the Eurasian Economic union and the Republic of Belarus]. Health Risk Analysis, 2015, no. 3, pp. 13-18. DOI: 10.21668/health.risk/2015.3.02.eng

10. Fokin V.A. Identifikatsiya opasnosti s posleduyushchim provedeniem otsenki riska ostatochnykh kolichestv kadmiya v pishchevoi produktsii kak faktora riska razvitiya negativnykh effektov na zdorov'e cheloveka [Hazard identification, followed by risk assessment of residues of cadmium in food as a risk factor for adverse effects on human health]. Sanitarnyi vrach, 2015, no. 10, pp. 63-67 (in Russian).

11. Formirovanie Evraziiskogo Ekonomicheskogo Soyuza: riski i shansy. Ezhegodnyi doklad Integratsionnogo kluba pri Predsedatele Soveta Federatsii Federal'nogo Sobraniya RF za 2014 god [Creation of the Eurasian Economic Union: risks and opportunities. The annual report by the Integration club supervised by the Chairman of the Federal Council, the RF Federal Assembly, 2014]. Moscow, Izdanie Soveta Federatsii, Publ., 2015,95 p. (in Russian).

12. Solodovnikov Yu.P., Gladkikh A.M., Shusherina T.F., Andreeva I.V., Tibekin A.T., Lytkina I.N., Ermolenko M.V. Epidemicheskaya vspyshka pishchevogo otravleniya vo vremya svad"by (chast' 1) [An epidemic outbreak of food poisoning during the wedding (part 1)]. Zhurnal mikrobiologii, epidemiologii i immunobiologii, 2005, no. 1, pp. 111-112.

13. Eriksson J., Öborn I., Olsson I.-M., Oskarsson A., Skerfving S., Eriksson J. Cadmium in food production systems: a health risk for sensitive population groups. Ambio, 2005, vol. 34, no. 4-5, pp. 344-351.

14. Phillips Ia., Casewell M., Cox T., De Groot B., Friis Ch., Jones R., Nightingale Ch., Preston R., Waddell J. Does the use of antibiotics in food pose a risk to human health? A critical review of publishing data. Journal of Antimicrobial Chemotherapy, 2004, vol. 53, no. 1, pp. 28.

15. FAO Risk based imported food control. Rome. 2016. Available at: http://www.fao.org/3/a-i5381e.pdf (07.08.2017).

16. General Use Products: Certification and Testing / United States Consumer Product Safety Comission. Business \& Manufacturing. Testing Certification. Available at: https://www.cpsc.gov/Business--Manufacturing/TestingCertification/General-Use-Products-Certification-and-Testing/ (07.08.2017).

17. Guidance for risk assessment of food and feed from genetically modified plants. EFSA Journal, 2011, no. 9 , pp. 2150 .

18. New Legislative Framework. European Commission: Single Market for Goods. Available at: https:// ec.europa.eu/growth/single-market/goods/new-legislative-framework_en (07.08.2017).

19. Overview Reports. European Commission: Food. Health and Food audits and analysis. Available at: http://ec.europa.eu/food/audits-analysis/overview reports/index.cfm (07.08.2017).

20. Port Surveillance News: CPSC Uses Pilot Risk Assessment Tool to Strengthen Import Safety Program. CPSC.gov is the U.S. government's official web portal, 2013. Available at: https://www.cpsc.gov/newsroom/newsreleases/2014/cpsc-uses-pilot-risk-assessment-tool-to-strengthen-import-safety (07.08.2017).

21. Snyder v. Am. Ass'n of Blood Banks, 144 N.J. 269 (N.J. June 4, 1996). Available at: https://www.casebriefs.com/blog/law/torts/torts-keyed-to-dobbs/the-duty-to-protect-from-third-persons/snyder-v-american-association-of-blood-banks (07.08.2017).

Zaitseva N.V., May I.V., Sychik S.I., Fedorenko E.V., Shevchuk L.M. Analysis of legal and methodological grounds for risk-oriented surveillance over consumer products: tasks and development prospects in the Eurasian Economic Union. Health Risk Analysis, 2017, no. 4, pp. 4-22. DOI: 10.21668/health.risk/2017.4.01.eng

Received: 08.09.2017

Accepted: 15.12.2017

Published: 30.12 .2017 


\title{
SCIENTIFIC AND METHODICAL APPROACHES TO RISK ANALYSIS IN HYGIENE AND EPIDEMIOLOGY
}

UDC 519.235; 613.6.02

DOI: $10.21668 /$ health.risk/2017.4.02.eng

\section{BEWARE, PERSON-YEARS! EXPERIENCE OF SIMPSON PARADOX OBSERVATION IN EPIDEMIOLOGICAL RISK EXAMINATIONS}

\author{
V.F. Obesnyuk \\ Southern Urals Institute for Biophysics of the Russian Federal Medical-Biological Agency, 19 Ozrskoe highway, \\ Ozersk, 456780, Russian Federation
}

It is shown, on the examples of concrete publications, that "person-years" category application in multifactor health risks analysis can lead to false conclusions in the process of observation data grouping due to Simpson paradox influence when examinations are performed via demographic or epidemiological techniques. The paradox occurs when heterogeneous strata are being compared. "Person-years" category first appeared in the middle of the 17th century, long before first applications of mathematical tools in statistics and probability theory; it does not fully correspond to up-to-date requirements of epidemiological research. Risk theory should change 17-18 century paradigm as it focuses on conditional probability of unwanted events occurrence and not on a principle of comparing their intensities. It is particularly vital in case when we deal with determining possible damage to health caused by effects exerted by such factors and under such conditions when individual damage cannot be measured objectively but when it is possible to quantitatively determine regularities of changes in stochastic ability to survive for a large group of people or remote consequences occurrence for it.

We prove it is necessary to create specialized mathematical tools and hybrid software able to solve a risks assessment task as an inverse one. Mathematical tools of large contingency tables could serve as prototypes of such tools; we can also use multi-factor logistical and Poisson regressions which are usually applied in countable events analysis. We should note that it is also necessary to eliminate a number of methodological drawbacks which are attributable to the said tools.

Key words: lifelong risk, cohort, epidemiology, parameter, intensity, Simpson paradox, factor, remote consequences, software.

"Person-years" category [9] came to life when risks related to possible negative consequences for health were analyzed, first in population research, and later, in cohort one. An epidemiologic dictionary gives the following definition for the term: "Person-time is a dimension combining people and time in a denominator in calculating incidence and mortality ..., when individuals run risks of a disease or a lethal outcome during different time periods. It is a sum of all the time periods during which all the individuals ran risks".
Obviously, John Graunt [3] was the first researcher who actually applied this concept in the middle of the 17th century. A number of observed person-years has been traditionally applied to assess mortality or morbidity intensity which are thought by most practicing epidemiologists to be directly related to such terms as "risk" or "risk parameter":

$$
\lambda=\frac{\Delta M}{\Delta A},
$$

where $\Delta M-$ is a number of "cases" over an

(C) Obesnyuk V.F., 2017

Valery F. Obesnyuk - Candidate of Physical-Mathematical Sciences; Associate Professor; Senior Researcher at Radiation Epidemiology Laboratory (e-mail: v-f-o@subi.su; tel.: +7 (351) 307-52-36). 
observation period; $\Delta A-$ is a number of observed person-years.

We should note that value had first been applied before mathematics started to develop rapidly after differential and integral calculus were discovered as well as before probability theory and mathematical statistics were created. English reference books also determine the parameter as stratum-specific rate, or as "hazard". It was demographists who strove to apply it both in descriptive and mathematical statistics [3]. The word "statistic" itself is known to be first introduced by Gottfried Achenwal in 1746 as an equivalent for a "state study" subject in Marburg and Gottingen Universities, that is, in a descriptive meaning of the term.

Contemporary risk theory changes 17 18 centuries paradigm as it is based on probability category [1] and determines a risk as a probability of unwanted events occurrence (under a combination of certain conditions, that is as a conditional probability). It is especially vital for scientific demography and evidential epidemiology if we speak about determining possible health damage caused by such factors and under such conditions when it is impossible to objectively measure an individual damage but we can quantitatively determine regularities of changes in stochastic survival rate for a large group of people or long-term effects occurrence. Search for scientific approaches to measuring such biological effects has been intensified since 70ties last century in relation to all-around growth in chemical, pharmaceutical, radiation, ecological and other technogenic risks.

At first sight this change in scientific paradigm doesn't contradict to "personyears" category as a distribution of members in a homogenous examined cohort can be described with a function of distribution as per age $t$ :

$$
F(t)=1-\exp \left(-\int_{0}^{t} \lambda(\tau) d \tau\right),
$$

where $\lambda(t)$ is an intensity of mortality caused by all reasons, for example; is a death risk and it is also a distribution function. Here $\lambda(t)==F^{\prime}(t) /(1-F(t))$ or $\lambda(t)=-S^{\prime}(t) / S(t)$, where $S(t)$ - a survival function $S(t)=1-F(t)$.

Distribution function and survival function are assessed empirically. Due to it we can come to the formula (3) at any finite interval of observation $\Delta t$ at a sufficient examined sampling value $N_{0}$ together with the condition $N(t) \approx N_{0} S(t)$ :

$$
\begin{gathered}
\lambda(t)=-S^{\prime}(t) / S(t) \approx \\
\approx-\frac{N_{0}(S(t+\Delta t)-S(t))}{N_{0} S(t) \Delta t}=-\frac{\Delta N}{\Delta A}=\frac{\Delta M}{\Delta A} .
\end{gathered}
$$

Therefore, such concepts as risk and risk intensity are equal in a descriptive sense. So it seems, all we have to do is to select a reference group and come to some conclusions. But application practices tell us it would be wrong. And it is not only because risks intensities ratios and ratios of risks themselves in a focus group and a reference one differ in their meaning and value, but also because each of these parameters is determined for a homogenous group, and the parameters themselves should differ only as per 1 examined factor. However, it is this circumstance that is not always strictly controlled by researchers.

Our research goal was to highlight typical observation examples for Simpson paradox when heterogeneous groups were compared when heterogeneity was observed as per more than 1 factor controlled by a researcher. This paradox has been 
known since Karl Pearson's time (1900) but it has been repeatedly rediscovered. Uncontrolled factors are also known as "disturbing" variables. A technique involving comparison between a focus group and a reference one actually leads to contingency tables estimate. They are built both on direct risk comparison principle (classic contingency tables) and on a principle when events observation intensities are compared. And "person-years' category is exactly applied in the latter case. To illustrate mathematic artifacts Simpson's paradox belongs to we suggest to look at Table 1.

Table 1

Comparative analysis of mortality among white women in Miami and Alaska in 1970

\begin{tabular}{|c|c|c|c|c|c|c|}
\hline \multirow{2}{*}{ Age group } & \multicolumn{3}{|c|}{ Miami } & \multicolumn{3}{c|}{ Alaska } \\
\cline { 2 - 6 } & $\begin{array}{c}\Delta A, \\
\text { people } \times \text { year }\end{array}$ & $\begin{array}{c}\Delta M \\
\text { (died) }\end{array}$ & $\begin{array}{c}\text { Parameter, } \\
\text { (\%o per year) }\end{array}$ & $\begin{array}{c}\Delta A, \\
\text { people×year }\end{array}$ & $\begin{array}{c}\Delta M \\
\text { (died) }\end{array}$ & $\begin{array}{c}\text { Parameter, } \\
\text { (\%o per year) }\end{array}$ \\
\hline$<15$ & 114350 & 136 & 1,19 & 37164 & 59 & 1,59 \\
\hline $15-24$ & 80259 & 57 & 0,71 & 20036 & 18 & 0,90 \\
\hline $25-44$ & 133440 & 208 & 1,56 & 32693 & 37 & 1,13 \\
\hline $45-64$ & 142670 & 1016 & 7,12 & 14947 & 90 & 6.02 \\
\hline $65+$ & 92168 & 3605 & 39,11 & 2077 & 81 & 39,00 \\
\hline All ages* & $\mathbf{5 6 2 ~ 8 8 7}$ & $\mathbf{5 0 2 2}$ & $\mathbf{8 , 9 2}$ & $\mathbf{1 0 6 9 1 7}$ & $\mathbf{2 8 5}$ & $\mathbf{2 , 6 7}$ \\
\hline
\end{tabular}

Note: ${ }^{*}$ - crude rate.

As we can see, parameters are statistically significantly different between all the age groups in each region $(p<0.02)$. However, if we compare each age group in different regions we can see there are no statistically significant discrepancies $(p \geq 0.05)$. At the same time combined (crude) mortality parameters in the same regions can paradoxically differ, and this difference can reach 3 times (8.92 against 2.67 people per 1,000 a year; $p<0.001)$. Demographists understand the reason for the artifact quite well. It is that when strata were combined, such a hidden factor as regional difference in people distribution as per age played its role. A combined regional stratum turned out to be heterogeneous. And a way to correct the mistake here is also well known. Indeed, we can introduce any "standard" distribution as per age categories in our consideration, for example, simply combining two administrative units in one.
Then the parameters assessment will be reduced to simple calculation of a weighted average as per age group. For example, let us fix shares distribution structure in a unified standard with the following ratios: $0,23: 0,15: 0,25: 0,23: 0,14$. The parameter will be equal to $7.88 \%{ }^{\bullet}$ year ${ }^{-1}$ for "Miami" sub-group, and for Alaska sub-group, to $7.63 \%{ }^{\bullet}$ year $^{-1}$. Obviously, given the observed discrepancy, now we can't state there are statistically significant differences in health of population living in these two regions. And a paradox would seem to be overcome.

However, standardization procedure itself doesn't remove heterogeneity. No wonder, that standardized annual risk parameter is being criticized [15] as it is impossible to make any judgments on population being healthy/unhealthy only on its value. You can come to this conclusion yourselves if, for example, you compare three age dependences for intensity of mor- 
tality caused by lung cancer for three different population groups where standardized risk was arithmetically identical (Figure 1), but lifelong risk was 1.25 times different and its values were higher not in a cohort where specific mortality was maximum intense.

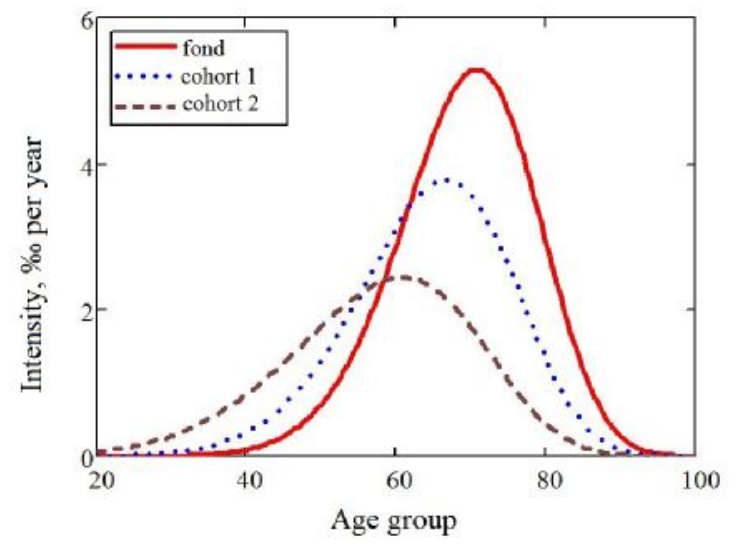

Figure 1. Age dependence for intensity of mortality caused by lung cancer in three different make cohorts with the same standardized parameter 68:100,000 annually. Mathematic modeling result.

Indeed, let us assume that cohorts 1 and 2 were exposed to different impacts exerted by a certain pollutant. The background cohort with zero exposure is used as a reference group. Obviously, if we don't apply standardized risk parameter but choose a probable damage done to a cohort health, we will obtain higher parameter for cohort 2. It is explained by the following: deaths caused by cancer in cohort 2 in the same volumes will be registered earlier and this, as we can calculate, will lead to a greater cumulative effect and a lifelong risk of death due to cancer can serve as an example of this effects. So, if changes in distribution form is a response to impacts exerted by a pollutant then we should choose a correct biologic effect measure. It can't be equal to just "average temperature in a hospital".

Works by a well-known group of researchers [2,4,6-8] also contain an incorrect application of annual risk parameters and Poisson regression. According to their observations, there is a statistically significant decrease in morbidity with arterial hypertension together with growth in an internal irradiation dose on the liver which is higher than 0.05 Gy among men contacting $\mathrm{Pu}$ compounds (Table 2). Meanwhile, 0.05 $\mathrm{Gy} \mathrm{Pu}$ dose is equal to an external irradiation dose of $1.0 \mathrm{~Sv}$ which corresponds to 50 years of work with fixed dose limits of tolerable irradiation being equal to 20 $\mathrm{mSv} / y e a r$ for professionals. So, this "favorable" impact exerted by $\mathrm{Pu}$ on male bodies doesn't correspond to the existing Radiation Safety Standards ${ }^{1}$. This phenomenon can be explained almost ion the same way as in case with table 1 , but here we can see more sources of strata heterogeneity as the samplings are made up of workers employed at various technological sectors with two completely different radiation types. Even risk parameters standardization the authors were quite able to apply didn't help them much [4]!

The same researchers "found" even greater paradoxes due to their heterogeneous groups examination. Thus, when studying consequences of chronic influence exerted by ionizing radiation on intensity of mortality caused by cerebrovascular diseases, they "revealed" that if male workers received alpha-radiation within a dose range equal to $0.1-0.5 \mathrm{~Gy}$, then mor-

${ }^{1}$ SER 2.6.1.2523-09. Radiation Safety Standards (НРБ-99/2009). 2009, 225 c. Available at: https://www.google.ru/url?sa=t\&rct=j\&q=\&esrc=s\&source=web\&cd=3\&ved=0ahUKEwiT2unF9PLXAhWFDpoKHf9 pBdUQFgg0MAI\&url=http\%3A\%2F\%2Fnucloweb.jinr.ru\%2Fnucloserv\%2Finform\%2Finstructions\%2Fnrb-992009.pdf\&usg=AOvVaw1jm3EcC5xkTjs2NMZ8d7Rt (28.08.2017). 
tality grew together with a dose, but as for the overall male part of a cohort, they "observed" statistically significant decrease with the following trend: $\mathrm{ERR}_{\mathrm{Gy}}=-0.056 \mathrm{G} y^{-1}(95 \% \mathrm{CI}$ : from $-0,094$ to $-0,018)$ [8]. They managed not to come to conclusions that internal irradiation caused by radionuclides which penetrated a body was actually "useful", but Simpson paradox was well there. There is another similar work where performed research results are applied by its authors to state that regular alcohol intake by male workers from the same cohort causes an increase in morbidity with cerebrovascular diseases with high confidence probability level [6]. On the contrary, the same parameter for women is lower among those drinking alcohol. And here we also see that absurdity and Simpson paradox go hand in hand.
Dose trend assessment inconformity which occurs in examinations of senile cataract is also obvious there where these assessments are based on intensity of the disease evolvement risk [2]. For example, we can see in Table 3 that if observation grouping was one-factor, as per radiation dose in the basic workers' group with Radiation Safety Standards ${ }^{1}$ being undoubtedly met, morbidity parameter was $\lambda_{0}=1631 / 255036=6.39 \%$. year ${ }^{-1}$. However, the same parameter was $\lambda_{4}=12.31 \%$ - year ${ }^{-1}$ in a group who received more than 1 Gy. Then excess relative risk per a dose unit within a hypothesis on a linear trend would be equal to (4):

$$
\text { È } ̂ \hat{~} \bigoplus_{\tilde{A} \tilde{d}} \approx \frac{\lambda_{4}-\lambda_{0}}{\lambda_{0}\left(D_{4}-D_{0}\right)}=0,89 \tilde{\mathrm{A}} \mathrm{\gamma}^{-1}
$$

Table 2

Morbidity with arterial hypertension among workers employed at PA "MAYAK", exposed to different internal irradiation doses [4]

\begin{tabular}{|c|c|c|c|c|c|c|}
\hline \multirow{2}{*}{ Sex } & \multicolumn{2}{|c|}{$D<0,025$ Gy } & \multicolumn{2}{c|}{$0,025-0,05$ Gy } & \multicolumn{2}{c|}{$D>0,05$ Gy } \\
\cline { 2 - 7 } & $\begin{array}{c}\text { Number of } \\
\text { cases }\end{array}$ & $\begin{array}{c}\text { Parameter } \\
\text { (\%) per year) }\end{array}$ & $\begin{array}{c}\text { Number of } \\
\text { cases }\end{array}$ & $\begin{array}{c}\text { Parameter } \\
\text { (\%o per year) }\end{array}$ & $\begin{array}{c}\text { Number of } \\
\text { cases }\end{array}$ & $\begin{array}{c}\text { Parameter } \\
\text { (\%o per year) }\end{array}$ \\
\hline Men & 1416 & $21,11 \pm 0,5$ & 481 & $20,65 \pm 1,1$ & 963 & $17,74^{*} \pm 0,72$ \\
\hline Women & 694 & $18,59 \pm 0,71$ & 253 & $21,42 \pm 1,68$ & 600 & $20,61 \pm 1,09$ \\
\hline
\end{tabular}

Note: * Statistically significant observation.

Table 3

Relative risk (RR) of morbidity with cataract depending on a cumulative external gamma-irradiation [2]

\begin{tabular}{|c|c|c|c|c|}
\hline $\begin{array}{c}\text { Cumulative dose of } \\
\text { external } \\
\gamma \text {-irradiation }(\mathrm{Gy})\end{array}$ & $\begin{array}{c}\text { Average dose of } \\
\text { external } \\
\gamma \text {-irradiation (Gy) }\end{array}$ & $\begin{array}{c}\text { Person-years of } \\
\text { observation }\end{array}$ & Cataract cases & $\begin{array}{c}\text { RR } \\
(95 \% \mathrm{CI})\end{array}$ \\
\hline$(0-0,25)$ & 0,08 & 255036,0 & 1631 & 1 \\
\hline$[0,25-0,50)$ & 0,36 & 69097,1 & 702 & $1,23(1,11-1,35)$ \\
\hline$[0,50-0,75)$ & 0,62 & 35678,2 & 365 & $1,13(1,00-1,28)$ \\
\hline$[0,75-1,00)$ & 0,87 & 25915,0 & 321 & $1,38(1,21-1,57)$ \\
\hline$[1,00-1,25)$ & 1,12 & 18191,8 & 224 & $1,43(1,23-1,66)$ \\
\hline$[1,25-1,50)$ & 1,37 & 15147,2 & 217 & $1,57(1,34-1,83)$ \\
\hline$[1,50-2,00)$ & 1,73 & 20066,3 & 296 & $1,59(1,39-1,83)$ \\
\hline$>=2,00$ & 2,67 & 25498,0 & 387 & $1,61(1,41-1,83)$ \\
\hline
\end{tabular}


And it is even higher in small doses range. However, E.V. Bragin et al. give another estimation in their work performing it partially allowing for observations stratification, but for the overall cohort, namely $\mathrm{E} R R_{\mathrm{Gy}}=0.28 \mathrm{~Gy}^{-1}(95 \% \mathrm{CI}: 0.20-$ 0.37) [2]. That is, one estimation doesn't match within a confidence interval of the another and they are approximately three times different from each other. Again, Simpson paradox. And what estimations are we to trust here? Probably, not one of them.

T.V. Azizova et al. made an attempt to separately examine influence exerted by two ionizing radiation types on circulatory system diseases (CSD) within a separate one-factor analysis framework, but it again led to a paradox [7]. Excess relative risk per a dose unit under exposure to external gamma-irradiation was $(95 \% \mathrm{CI}: 0.0$ $0.11)$. They also detected a statistically significant rising trend for CSD-caused mortality as an absorbed dose of internal alpharadiation in liver was growing: $(95 \% \mathrm{CI}$ : $0.12-0.48)$. Given relative biological efficiency of alpha-radiation in comparison with gamma-radiation, we obtain the following: (95\% CI: 2.4-9.6), which is substantially higher than among victims of Hiroshima and Nagasaki bombing and is extremely strange by itself. But it didn't prevent the authors from stating that "... Research results ... are well in line with risk assessments obtained in a Japanese cohort of people who survived in atomic bombing ...". We should note that the authors saw how "... decreased and became statistically insignificant when an adjustment as per an external gamma-irradiation was introduced" [2].

This "person-years" category is widely used in epidemiologic research on radiation effects. And it is this category that makes risk researchers come to unjustified conclu- sions and generalizations which ignore initial probabilistic meaning of parameters introduction. There is a serious methodological defect when we measure "hazard" parameters when assessing death risk in radiation-epidemiologic research and not "risk" itself. Logical contradiction is especially typical when stochastic events in a cohort are examined. They usually depend on an impact dose which is cumulative in its sense while a risk parameter is a "momentary" property of a cohort which can be attributed to a certain age. One-value correlation between and a dose seems logical for acute impacts exerted by a hazardous substance but it is totally non-relevant for long-term ones. For example, chronic low intense irradiation involves a correlation between age and dose. If stratification which is usual for epidemiology is made as per both these values than it will be natural in case of low irradiation doses that an observed dose will be higher for people with comparatively older ages of death. Maximum likelihood techniques application according to Epicure Users Guide [23] will lead to false interpretation of this fact: registered life span will be higher for cohort members with greater doses, but "momentary" specific mortality parameters will be lower for them. So, application of mortality/morbidity intensity parameter can cause epidemiologic "observation" of false hormesis which actually could be not more than just a mathematical artifact. In spite of the subjunctive mood applied in the previous sentence, the author is sure that the above-mentioned artifact was repeatedly observed in small doses area where it should obviously be most apparent. And this phenomenon was thought by many researchers to be a true radiationepidemiologic hormesis or even anti-tumor effect [10-16, 18-22, 24, 25]. 
Risk assessment issues: discussion and analysis. Basic risk factors awareness and standardization underlies state sanitaryepidemiologic control and surveillance. But each science based on experience requires its own unique toolset. It is not enough to simply give a theoretical definition of risk. It is also necessary to be able to measure it practically. Risk is always caused by several internal and external reasons, that is, it is a multi-factor value. We can provide strict one-factor risk dependence in an experiment only, which, due to ethical reasons, cannot always be performed on people. Multi-factor epidemiologic or clinical-epidemiologic research is an alternative. Risk management practice is not possible without this information as it requires an ability to predict risks in preset sanitary-epidemiologic conditions.

Analysis of existing risk assessment practices reveals that it is hard to adapt traditional contingency tables or one-factor statistic tools to multi-factor randomized observations. As we have already stated, Poisson regression built on wrong application of "person-years" observation category can lead to false conclusions. A solution to a problem can be a transition to assessment of strictly stochastic specific risk parameters, for example conditional lifelong risk. There is a positive example in radiation epidemiology sphere acknowledged by International Commission on Radiological Protection (ICRP) [5].

Statistic research algorithm based on cumulative effects assessment can be applied in non-radiation effects analysis but only if their value can be characterized with certain cumulative "doses". Risk can be only conditional, so it will depend on sex, exposure occurrence moment, a moment of individual effects observation in a group, on concomitant physiological processes which can influence an observed effect marker, on smoking status, on damage localization, and on exposure nature. Even a biological effect observation technique (diagnostic technique) can a factor which causes a sampling heterogeneity. "Detectability" category is applied by epidemiologists not for nothing. And finally, examined long-term effects risk depends on how possible realization of other lethal risks is. All these factors are conditions for conditional probability realization and so they are also to be conditions for its assessment.

Conclusions. Assessment of lifelong risk and its dose trend in any heterogeneous cohort is a complicated statistical multi-factor analysis problem which cannot be solved without specialized computing facilities. As a rule, universal software which is available at present is not suitable for the purpose. It is necessary to work out specialized software able to solve risk assessment task as a inverse one. A logistic regression could be a prototype if we don't overemphasize a logistic function role here; it would be better to replace it with a more flexible approximation tool. For example, it is possible to apply artificial neuron networks as a generator of models describing correlations between risks and examined factors. In particular, it would allow to give up stratification of randomized observations results and, consequently, to exclude well-known influence exerted by strata limits setting on assessment results. There are a lot of spheres in medicine and healthcare where all the abovementioned can be applied, for example, predictions made on screening results (oncology, cardiology, gastroenterology etc.), medical statistics, cohort and clinical epidemiology, clinical toxicology, as well as development of software for processing other statistic data which are of probabilistic nature. 


\section{References}

1. Analiz riska zdorov'ju v strategii gosudarstvennogo social'no-jekonomicheskogo razvitija [Health risk analysis in the strategy of state social and economical development]. In: G.G.Onishhenko, N.V. Zaitseva, eds. Moscow, Perm', Perm. nac. issled. politehn. universitet, Publ., 2014, 738 p. (in Russian).

2. Bragin E.V., Azizova T.V., Bannikova M.V. Risk zabolevaemosti starcheskoj kataraktoj u rabotnikov predprijatija atomnoj promyshlennosti [Risk of senile cataract among nuclear industry workers]. Vestnik oftal'mologii, 2017, vol. 133, no. 2, pp. 57-63 (in Russian).

3. Graunt Dzh., Gallej Je. Nachala statistiki naselenija, medicinskoj statistiki i matematiki strahovogo dela [The beginning of population statistics, medical statistics and actuarial science].Translation by O.B. Shejnina. Berlin, 2005, 134 p. (in Russian).

4. Kuznecova K.V., Azizova T.V., Bannikova M.V. [i dr.]. Pokazateli zabolevaemosti arterial'noj gipertenziej v kogorte rabotnikov atomnoj promyshlennosti [Arterial hypertension incidence rates in a cohort of nuclear workers]. Arterial'naja gipertenzija, 2016, vol. 22, no. 3, pp. 299-308 (in Russian).

5. Publikacija 103 Mezhdunarodnoj Komissii po radiacionnoj zashhite (MKRZ) [Annals of the ICRP: Published on behalf of the International Commission on Radiological Protection]. In: M.F. Kiseljov, N.K. Shandala, eds. Moscow, OOO PKF «Alana» Publ., 2009, 344 p. (in Russian).

6. Azizova T.V., Moseeva M.B., Grigor'eva E.S. [i dr.]. Risk zabolevaemosti i smertnosti ot cerebrovaskuljarnyh zabolevanij $\mathrm{v}$ kogorte pervogo $\mathrm{v}$ Rossii predprijatija atomnoj promyshlennosti [Incidence and Mortality risks from Cerebrovascular Diseases in the Cohort of Workers of the First Russian Nuclear Facility]. Medicinskaja radiologija i radiacionnaja bezopasnost', 2012, vol. 57, no. 1, pp. 17-29 (in Russian).

7. Azizova T.V., Grigor'eva E.S., Hanter N., Pikulina M.V., Moseeva M.B. Risk smerti ot boleznej sistemy krovoobrashhenija $\mathrm{v}$ kogorte rabotni-kov, podvergshihsja hronicheskomu oblucheniju [Risk of death from circulatory diseases in a cohort of patients exposed to chronic radiation]. Terapevticheskij arhiv, 2017, vlol. 89, no. 1, pp. 18-27 (in Russian).

8. Azizova T.V., M'jurhed K.R., Moseeva M.B. [i dr.]. Riski zabolevaemosti i smertnosti ot cerebrovaskuljarnyh zabolevanij v kogorte rabotnikov PO «MAJaK», podvergshihsja hronicheskomu oblucheniju [Incidence of and Mortality from Cerebrovascular Diseases in the Cohort of Mayak Production Association Workers Chronically Exposed to Radiation]. Medicinskaja radiologija i radiacionnaja bezopasnost', 2010, vol. 55, no. 6, pp. 26-38 (in Russian).

9. Jepidemiologicheskij slovar'. Chetvertoe izdanie [Epidemiological dictionary. The fourth edition]. In: Dzh.M. Lasta, ed. Moscow, OIZ Publ., 2009, 316 p. (in Russian).

10. Yamada S., [et al.]. Anti-tumor effect of low dose total (or half) body irradiation and changes of the functional subset of peripheral blood lymphocytes in nonHodgkin's lymphoma patients. Low Dose Irradiation and Biological Defense Mechanisms. Amsterdam: Experta Medica Publ., 1992, pp. 113-116.

11. Thompson R.E., [et al.]. Case-control study of lung cancer risk from residential radon exposure in Worcester County, Massachusetts. Health Phys., 2008, vol. 94, pp. 228-241.

12. Cohen B.L. Cancer risk from low level radiation. American Journal of Roentgenology, 2002, vol. 179, pp. 1137-1143.

13. Cohen B.L. Test of the LNT theory of radiation carcinogenesis for inhaled radon decay products. Health Physics, 1995, vol. 68, no. 2, pp. 157-174.

14. Cohen B.L. The cancer risk from low level radiation. Health Phys., 1980, vol. 39, pp. 659-678. 
15. Cohen B.L. The cancer risk from low level radiation. Radiat. Res., 1998, vol. 149, pp. 525-526.

16. Wei L., Zha Y., Tao Z., [et al.]. Epidemiological investigation of radiological effects in high background radiation areas of Yangjiang China. J. Radiation Res., 1990, vol. 31, no. 1, pp. 119-136.

17. Gaffey W.R. A Critique of the Standardized Mortality Ratio. Journal of Occupational Medicine, 1976, vol. 18, no. 3, pp. 157-160.

18. Haynes R.M. The distribution of domestic radon concentrations and lung cancer mortality in England and Wales. Radiation Protection Dosimetry, 1988, vol. 25, no. 1, pp. 93-96.

19. Howe G.R. Lung Cancer Mortality Between 1950 and 1987 after Exposure to Fractionated Moderate-Dose-Rate Ionizing Radiation in the Canadian Fluoroscopy Cohort Study and a Comparison with Lung Cancer Mortality in the Atomic Bomb Survivors Study. Radiat. Res., 1995, vol. 142, pp. 295-304.

20. Kostyuchenko V.A., Krestinina L.Yu. Long term irradiation effects in the population evacuated from the East-Urals radioactive trace area. Scient. Total Environment, 1994, vol. 142, no. 1, pp. 119-125.

21. Davis F.G., Boice J.D., Hrubec C., [et. al.]. Lung cancer mortality in a radiationexposed cohort of Massachusetts tuberculosis patients. Cancer. Res., 1989, vol. 49, pp. 61306136.

22. Nambi K.S.V., Soman S.D. Environmental radiation and cancer in India. Health Physics, 1987, vol. 52, no. 5, pp. 653-657.

23. Preston D., Lubin J., Pierce D. Epicure User's Guide. Hirosoft I.C., 1998, 344 p.

24. Rossi H.H., Zaider M. Radiogenic lung cancer: The effects of low doses of low linear energy transfer (LET) radiation. Radiat. Environ. Biophys, 1997, vol. 36, pp. 85-88.

25. Sheynin O. Theory of Probability. A Historical Essay. 2-nd ed. Berlin, 2009, 273 p.

Obesnyuk V.F. Beware, person-years! Experience of Simpson paradox observation in epidemiological risk examinations. Health Risk Analysis, 2017, no. 4, pp. 23-31. DOI: 10.21668/health.risk/2017.4.02.eng

Received: 28.08 .2017

Accepted: 20.12.2017

Published: 30.12 .2017 
UDC 616.9-036.22-085-039.78

DOI: 10.21668/health.risk/2017.4.03.eng

\title{
METHODOLOGICAL APPROACHES TO ASSESSING ECONOMIC EFFECTS OF ACTIVITIES AIMED AT MINIMIZING HEALTH RISKS RELATED TO EXTREMELY DANGEROUS INFECTIONS
}

\author{
V.Yu. Smolensky ${ }^{1}$, P.Z. Shur ${ }^{2}$, D.V. Suvorov ${ }^{2}$, O.I. Goleva ${ }^{2,3}$, V.A. Safronov ${ }^{4}$, \\ E.V. Khrushcheva ${ }^{2}$, I.V. Vindokurov ${ }^{2,5}$
}

${ }^{1}$ Federal Service for Surveillance on Consumer Rights Protection and Human Wellbeing, 18, bild. 5 Vadkovskiy pereulok, Moscow, 127994, Russian Federation

${ }^{2}$ Federal Scientific Center for Medical and Preventive Health Risk Management Technologies, 82 Monastyrskaya

Str., Perm, 614045, Russian Federation

${ }^{3}$ Perm State University, 15 Bukireva Str., Perm, 614990, Russian Federation

${ }^{4}$ «Microbe» Russian Scientific Research Anti-Plague Institute, 46 Universitetskaya Str., Saratov, 410005,

Russian Federation

${ }^{5}$ Perm National Research Polytechnic University, 29 Komsomolskiy avenue, Perm, 614990, Russian Federation

As we assess health risks caused by extremely dangerous infections, we can apply mathematical modeling to estimate a disease or a death case probability. This mathematical modeling describes epidemiological processes and allows to imitate their development without performing any anti-epidemic activities. Parameters which quantitatively assess morbidity and mortality cases obtained via this modeling together with actual data on losses which were not prevented even if anti-epidemic activities were in place, can be used as grounds for economic effects assessment. An economic effect of anti-epidemic activities was calculated in terms of indirect prevented losses which became possible due to decrease in mortality and morbidity; the effect was calculated in money units which were applied in the GDP calculation.

The calculation is performed in full conformity with 'The Methodology for calculating economic losses caused by population mortality, morbidity, and disability" (Moscow, 2012) and envisages assessment of losses in the current year and over a period of survival (for death cases).

The methodology was tested on the example of Ebola fever outbreak in Guinea in 2014-2016. The testing results revealed that if not for anti-epidemic activities which included substantial assistance rendered by other countries (the RF among them), a number of morbidity cases caused by Ebola virus would have reached 521,289, and a number of death cases, 56,345.

The RF Rospotrebnadzor made a significant contribution into Ebola fever outbreak elimination in Guinea; it sent a special anti-epidemic team there in August 2014. The team participated in diagnostic procedures, staff training, and anti-epidemic activities organization. Risk prevented due to assistance rendered by other countries, including the RF, amounted to 517,485 morbidity cases, and 53,809 death cases. Economic effects for Guinea achieved due to anti-epidemic activities aimed at risk minimization with the help of other countries is estimated to be equal to 229.51 million USD; it amounts to approximately 3.5\% of Guinea GDP.

Key words: risk assessment, economic effect, modeling, risk minimization, extremely dangerous infections, anti-epidemic activities, Ebola virus.

(C) Smolensky V.Yu., Shur P.Z., Suvorov D.V., Goleva O.I., Safronov V.A., Khrushcheva E.V., Vindokurov I.V., 2017

Vyacheslav Yu. Smolensky - Candidate of Medical Sciences, Head of the Department of Scientific Provision for Sanitary-epidemiologic Welfare of the Population and International Affairs (e-mail: aidscouncil@gsen.ru; tel.: +7 (499) 973-26-93).

Pavel Z. Shur - Doctor of Medical Sciences, Professor, Academic Secretary (e-mail: shur@ffrisk.ru; tel.: +7 (342) 238-33-37).

Dmitry V. Suvorov - Research Assistant (e-mail: dvs-86@mail.ru; tel: +7 (342) 238-33-37).

Olga I. Goleva - Candidate of Economics, Associate professor at Finance, Credit, and Stock Exchange Studies Department (e-mail: OlgaGoleva@psu.ru; tel: +7(342)239-62-94).

Valentin A. Safronov - Candidate of Medical Sciences, Senior Researcher (e-mail: neuromail@rambler.ru; tel.: +7 (845) 226-21-31).

Ekaterina V. Khrushcheva - Mathematician at Risk Management Techniques and Technologies Laboratory (e-mail: Khrrushceva@,fcrisk.ru; tel: +7 (342) 238-33-37).

Ilya V. Vindokurov - Mathematician at Risk Management Techniques and Technologies Laboratory, a first-year MA student at «Machines Dynamics and Endurance» Department of the Applied Mathematics and Mechanics Faculty (e-mail: dpm13b@mail.ru; tel: +7 (342) 238-33-37). 
The global practice conventionally refers diseases which can cause an emergency sanitary and epidemiological situation of international concern, according to WHO International Health Regulations (IHR-2005) ${ }^{1}$ to extremely dangerous infections (EDI). These infections are characterized by high contagiousness, have rapid epidemic spreading to large populations and /or can cause severe or persistent individual health disorders with a high probability of death in a short period since having been infected, or a long-term loss of ability to work, and disability of those who have recovered.

To reduce threats due to EDI, it is necessary to take preventive and anti-epidemic measures with an assessment of their outcome and effectiveness. Ap-proaches are known when, in assessing the effect of vaccine prophylaxis, the difference in incidence rates in vaccinated and unvaccinated groups was used as estimating parameters $[3,6]$.

In planning such measures, an assessment of their economic effect is getting ever higher relevance. At the same time, it is advisable to consider the prevented risk to public health as an effect of anti-epidemic activities [1, 5]. However, the approaches to assess this effect using risk criteria that allows for quantification of the avoided losses caused by EDI, and their economic evaluation have been poorly developed by now, both in the world and in Russia, since no 'risk' application found in EDI analysis.

When analyzing health risk caused by EDI, mathematical modeling of epidemiological process can be used to assess dis- ease and death probability, allowing to simulate its development at no antiepidemic activities in place, with quantification of morbidity and mortality cases [4, $10,14,17,20]$. Such information, together with the actual data on non-prevented losses, even in the context of measures to stop epidemy, can be used as a basis for assessing the economic effect of antiepidemic activities and, accordingly, to improve planning of future measures to counter EDI and their trans-border spreading.

It was considered relevant to test these approaches using the example of a disease caused by Ebola virus (EVD). The largest outbreak in the history of this infection was registered in 2014-2016 in three countries of West Africa (the Republic of Guinea, Liberia and Sierra Leone). The disease not only caused significant economic damage, but also became a serious threat to biological safety throughout the world.

The target of the work is to develop methodological approaches to assessing economic effects of activities to minimize health risks associated with especially dangerous infections, and test these methods using the example of EVD epidemic abortion in the Republic of Guinea.

Materials and methods. To develop methodological approaches, we studied 143 references to especially dangerous infections. We used search platforms (Pubmed, elibrary.ru). The average actual data on morbidity, mortality, population was obtained from open sources, such as the WHO website (http://www.who.int/en/), Pubmed (https://www.ncbi.nlm.nih.gov

\footnotetext{
${ }^{1}$ International Health Regulations (2005). 3rd ed. World Health Organization, 2016, 92 p. Available at: http://www.who.int/ihr/publications/9789241580496/ru/ (12.06.2017).
} 
/pubmed/). Economic data were obtained from official sources, such as the World Bank website (http://www.worldbank.org/ ), the UN database (http://data.un.org), the WHO website (http://www.who.int).

To simulate epidemic development without healthcare delivery, mathematical SEIHFR model was used, which describes quite fully the course of the disease [9].

The economic effect of anti-epidemic activities was calculated in terms of indirect prevented losses from reducing mortality and morbidity cases in monetary units of GDP. The calculation was carried out in accordance with 'The Methodology for calculating economic losses caused by population mortality, morbidity, and disability" (Moscow, 2012) approved by the Order of the Ministry of Economic Development, Ministry of Healthcare and Social Development, Ministry of Finance and Rosstat of April 10, 2012 No. 192/323n / $45 \mathrm{n} / 113^{2}$, taking into account the assessment of losses in the current year and survival period (for deaths cases). Evaluation of the effect in monetary terms makes it possible to calculate the economic effectiveness of such activities to reduce risks to population life and health from EDI.

When developing methodological approaches to assess economic effect of activities to minimize health risks associated with especially dangerous infections, the following provisions were taken into account:

1) assessment of morbidity and mortality risks associated with especially dangerous infections, without actions aimed at reducing it, is based on the results of mathematical modeling of the epidemic process;

2) assessment of morbidity and mortality risks associated with especially dangerous infections, when taking actions to reduce it, is based on evidence;

3) difference between the forecasted risk without actions and actual evidence data is considered as risk prevented in result of anti-epidemic activities.

The suggested methodical approaches include:

1) assessment of potential risks of morbidity and mortality due to EDI in case of epidemic natural spread using mathematical modeling;

2) analysis of actual evidence data on morbidity and mortality due to EDI;

3) assessment of prevented risks as a difference between potential risk and actual data;

4) economic assessment of prevented risk as an effect of anti-epidemic activities.

To calculate quantitative indicators of potential risks of morbidity and mortality due to especially dangerous infection, we suggest using mathematical models such as SEIR, SEIHFR for Ebola, SIR for HIV infection, etc. [14-16].

For such models, the key classes are:

- the number of susceptible individuals at risk at a time t;

- the number of infected individuals able to spread the disease at a time $t$;

- the number of individuals who left the previous class as a result of recovery or death, at a time $t$.

The given models can be implemented

\footnotetext{
${ }^{2}$ Methodology for calculating economic losses from mortality, morbidity and disability of the population / approved Order of the Ministry of Economic Development, the Ministry of Health and Social Development, the Ministry of Finance and Rosstat № 192/323H/45H/113 from 10 April 2012, 12 p. Available at: https://rg.ru/pril/73/43/77/23983_metodologiia.pdf (12.06.2017).
} 
using MATLAB application package.

The analysis of actual data on morbidity and mortality due to EDI is made using information from open sources, for example, the World Health Organization website, the PubMed library, the databases of the Centers for Disease Control, and others.

When assessing the preventable risk as the difference between potential risk and actual data on morbidity and mortality, it should be borne in mind that in some cases the incidence in the presence of effective anti-epidemic activities may be higher due to greater detectability of an infection. At the same time, mortality as a result of antiepidemic activities is usually reduced, due to early detection of a disease and timely assistance.

For economic evaluation of activities effect (or participation in similar activities) aimed at reducing health risk to the country's population, a scenario approach is envisaged. Scenarios of epidemic process natural development without anti-epidemic activities ("inaction model"), providing for the full realization of EDI morbidity and mortality due to this infection, and a scenario in which such a risk not being fully realized, owing to anti-epidemic activities ("actual").

Prevented losses in monetary terms (the prevented losses of the country's GDP) due to mortality and morbidity reduction are estimated as the difference between losses in monetary terms under "inaction model" and actual losses in monetary terms:

$$
\mathrm{PEL}=\mathrm{EL} " \mathrm{IM} "-\mathrm{EL}_{\text {actual, }}
$$

where PEL - prevented economic losses (effect of anti-epidemic activities);

EL"IM": economic losses under "inaction model" (losses due to EDI morbidity and mortality in population, without activities and expenditures for anti-epidemic activities);

ELactual: actual economic losses (losses due to population mortality and morbidity due to EDI).

Economic losses (for any scenario) are made up of economic losses from mortality and morbidity:

$$
\mathrm{EL}_{\mathrm{j}}=\mathrm{ELM}_{\mathrm{j}}+\mathrm{ELL}_{\mathrm{j}}
$$

where $\mathrm{EL}_{\mathrm{j}}$ - economic losses due to EDI related to mortality and morbidity of the population under scenario $\mathrm{j}$ (actual, "inaction model");ЭП $3_{j}-$ экономические потери от заболеваемости населения по сценарию $j$ (факт, «модель бездействия»);

ELM $_{\mathrm{j}}$ - economic losses due to the population morbidity under scenario $\mathrm{j}$ (actual, "inaction model");

$E_{L L}$ : economic losses due to the population lethality under scenario $j$ (actual, "inaction model").

Economic losses due to morbidity of the population as an effect of EDI for the year are calculated by the formula:

$$
\mathrm{ELMj}=\mathrm{ADMEj}^{\bullet} \mathrm{NMEj}^{\bullet} \frac{\mathrm{GDP}}{365^{\circ} \mathrm{NE}}
$$

where $\mathrm{ADME}_{j}$ - the average duration of a morbid event among the working-age population according to scenario $\mathrm{j}$ (actual, "inaction model");

$\mathrm{NME}_{\mathrm{j}}$ - the number of morbid events among the working-age population according to scenario $\mathrm{j}$ (actual, "inaction model");

GDP - the country's gross domestic product in the reporting year;

$\mathrm{NE}$ - number of employed in the country in the reporting year.

Economic losses as a result of mortality of the working-age population of the country where EDI has occurred for the year are calculated by the formula: 


$$
E L M_{j}=N D C_{j} \cdot \frac{G D P}{N E} \cdot\left(0,5+\sum_{i}^{70} L E_{i} \cdot p_{i}\right)
$$

where $\mathrm{NDC}_{\mathrm{j}}$ - the number of death cases among the population according to scenario $\mathrm{j}$ (actual, "inaction model");

$\mathrm{LE}_{i}$ - the level of employment in the country in the reporting year;

$p_{i}-$ probability of survival from age $\mathrm{x}-1$ to age $\mathrm{x}$ in the country under study.

0,5 - coefficient that takes into account the time of deaths distribution during a year (used only for the working-age population).

The proposed methodological approaches were tried out on the example of assessing the effectiveness of measures to stop the outbreak caused by Ebola virus (EVD) in the Republic of Guinea in 20132016.

In calculating quantitative indicators of the potential morbidity and mortality risks due to EVD in the Republic of Guinea, SEIHFR model was used, which includes the following variables:

- $\mathrm{S}(\mathrm{t})$ is the number of susceptible individuals at risk at a time $t$;

- $E(t)$ is the number of individuals with the disease in incubation period, at a time $t$;

- I(t) is the number of infected individuals able to spread the disease at a time $t$;

- $\mathrm{H}(\mathrm{t})$ is the number of individuals who were hospitalized, at the moment of a time t;

- $F(t)$ is the number of individuals who died at a time $t$;

- $R(t)$ is the number of individuals who dropped out of the previous class as a result of recovery or death at a time $t$

Study results and discussion. Using the parameters obtained by reviewing the sources data $[6,7,13,15]$ (Table 1) has

Table 1

Parameters applicable to mathematical SEIHFR model for EVD in the Republic of Guinea, for 2013-2016

\begin{tabular}{|l|c|}
\hline \multicolumn{1}{|c|}{ Parameters } & Parameter value \\
\hline Social contact speed, people in contact with 1 in-fected & 1,4 \\
\hline Contact speed in hospital, people in contact with 1 in-fected & 0,4 \\
\hline Contact speed at funeral, people in contact with 1 in-fected & 0,5 \\
\hline Incubation period, days & 12,7 \\
\hline Time prior hospitalization, days & 3,24 \\
\hline Time from hospitalization to death, days & 5,0 \\
\hline Duration of traditional funeral, days & 4,5 \\
\hline Duration of infection, days & 15,00 \\
\hline Time from infection to death, days & 13,31 \\
\hline Time from hospitalization to recovery, days & 15,88 \\
\hline Probability of hospitalization & 0,197 \\
\hline Mortality rate, not hospitalized & 0,6 \\
\hline Average duration of Ebola fever morbid case, days & 21 \\
\hline Patient mortality rate, hospitalized & 0,4 \\
\hline
\end{tabular}


shown that, based on the simulation results for the entire period of the epidemic in the Republic of Guinea in 2013-2016, 521,289 people could have been infected, 56,545 would have died. At the same time, as noted in the scientific literature, it should be taken into account that modeling due to inevitable simplification of the process under study, impossibility to consider its real characteristics under specific conditions, etc., cannot assure that the results obtained in this way reflect absolutely accurately the development patterns of a real epidemic process, which is probably reflected in the modeling of lethality [2,7]. When reviewing actual data on morbidity and mortality due to EVD, we established that the incidence rate of the diseases (NME) with Ebola fever for the entire period was 3,804 cases, and the frequency of deaths from
Ebola fever for the whole period was 2,536 people ${ }^{3}$.

Using the data obtained from modeling (forecasted risk) and the actual data (realized risk) on morbidity and mortality, we assessed the prevented risk. It was established that, provided the third countries assistance (including Russian Federation), 517,485 cases of infection with Ebola, and 53,809 lethal cases were prevented in the Republic of Guinea [2.7]. The data obtained were used to calculate the economic effect of activities to minimize health risks.

For the purpose of economic assessment for prevented risks as an effect of antiepidemic activities, in addition to the values shown in Table 1, we also used the medicaldemographic and economic parameters shown in Table 2.

Table 2

Medical-demographic and economic parameters to assess economic effects of antiepidemic activities to stop Ebola outbreak in Guinea, in 2014-2016

\begin{tabular}{|l|c|}
\hline \multicolumn{1}{|c|}{ Parameters } & Parameter value \\
\hline Population, people & 13247808 \\
\hline NE, million people & $6,138^{4}$ \\
\hline GDP, billion dollars & $6,579^{3}$ \\
\hline NME of Ebola fever for the entire period (actual), morbid cases & 3804 \\
\hline NME of Ebola fever for the entire period (under "inaction model"), morbid cases & 521289 \\
\hline Average duration of Ebola fever morbid event (actual), days & 15 \\
\hline Proportion of children / adults among the infected, \% & $20 / 80$ \\
\hline NDC due to Ebola fever for the entire period (actual), people & 2536 \\
\hline NDC due to Ebola fever for the entire period (under "inaction model"), people & 56345 \\
\hline
\end{tabular}

Different research groups studied the economic aspects of Ebola fever spreading in African countries:
- The World Bank Group reports $(2014,2015)$ contain data on the shortterm GDP losses in West Africa from 2.2

\footnotetext{
${ }^{3}$ UNData: A World of information. Available at: http://data.un.org (13.06.2017).

${ }^{4}$ Central Intelligence Agency. Available at: www.cia.gov (13.06.2017).
}

to 7.4 billion dollars (2014); medium- 
term losses are estimated at 1.6 to 25.2 billion dollars (depending on epidemic scenario) $[12,20]$;

- The studies by The United Nations Development Group in West and Central Africa contain information on the average forecasted losses in GDP, in 2014-2017, in Guinea at 184.4 million dollars annually, 187.7 million dollars in Liberia, from 219 million to 286 million dollars in Sierra Leone (depending on the scenario) $[8,18,19]$;

- According to the US Centers for Disease Control and Prevention, "2.2 billion dollars was the loss of GDP in Guinea, Liberia and Sierra Leone in 2015, posing a threat not only to macroeconomic stability, but also to the food security, human capital development and growth in the private sector"[11].

These studies considered both the direct and indirect losses from reduction of the country's labor resources. In all cases, a prerequisite for economic evaluation is the scenario analysis of events progress.

The prevented economic losses of Guinea's GDP due to morbidity, and effectiveness of anti-epidemic activities amounted to 25.5 million dollars and the prevented economic losses of Guinea's GDP from mortality: 204.01 million dollars. Thus, the effect of anti-epidemic activities amounted to 229.51 million dollars.

The effect reflects the prevented economic losses of the Republic of Guinea only from the reduction in the period of economic activity of the country's population as a result of mortality (in the reporting period, and for the period of survival to 70 years old) and morbidity (taking into account labor productivity in the country) from Ebola fever. Even in this case, the losses estimates are comparable with the results obtained earlier.

\section{Conclusions:}

1. Methodological approaches to assessing the effect of activities to reduce health risks caused by extremely dangerous infections (in this case, anti-epidemic activities) should include mathematical modeling of morbidity and mortality risks as a result of epidemic process, analysis of actual morbidity and mortality rates with an assessment of economic losses, caused by epidemic.

2. Approbation of the approaches proposed, as a result of epidemic process mathematical modeling using the example of Ebola outbreak in the Republic of Guinea, in 2014-2016, showed that without antiepidemic measures taken, including assistance from third countries, and Russian Federation in particular, the number of Ebola fever diseases could be 521,289 cases, and the number of deaths for this reason: 56,345 .

3 . The prevented risks owing to antiepidemic activities, including assistance from third countries, and Russian Federation in particular, made 517,485 cases and 53,809 deaths.

4. The economic effect of antiepidemic activities to minimize risks with the help of third countries, and Russian Federation, is estimated at 229.51 million dollars of Guinea GDP. 


\section{References}

1. Analiz riska zdorov'yu v strategii gosudarstvennogo sotsial'no-ekonomicheskogo razvitiya: monografiya [Health risk analysis in the strategy of state social and economical development]. In: G.G. Onishchenko, N.V. Zaitseva, eds. Moscow, Perm', 2014, 738 p. (in Russian).

2. Bashabshekh M.M., Maslennikov B.I. Imitatsionnoe modelirovanie prostranstvenno-kletochnykh avtomatov s pomoshch'yu programmy AnyLogic [Simulation modeling of the spatial spread of epidemics (cholera for example) using the method of cellular automata \using the Anylogic]. Naukovedenie: internet-zhurnal, 2013, no. 6 (19), The paper ID in the issue 135TVN613. Available at: http://naukovedenie.ru/PDF/ 135TVN613.pdf (30.06.2017) (in Russian).

3. Gendon Yu.Z. , Vasil'ev Yu.M. Epidemiologicheskaya i ekonomicheskaya effektivnost' zakrytiya shkol pri epidemiyakh i pandemiyakh grippa [Epidemiologic and economic effectiveness of school closure during influenza epidemics and pandemics]. Zhurnal mikrobiologii, epidemiologii i immunobiologii, 2012, no. 3, pp.113123 (in Russian).

4. Plavinskii S.L. Matematicheskoe modelirovanie rasprostraneniya infek-tsii, peredayushchikhsya polovym putem. Znachenie dlya obshchestvennogo zdorov'ya i zdravookhraneniya [Mathematical modeling of sexually transmitted infections spread. Public health implications]. Meditsina, 2013, no. 2, pp. 29-37 (in Russian).

5. Ushakov A.A., Saldan I.P., Goleva O.I., Karpova T.N. Fakticheskaya zabolevaemost' naseleniya sub"ekta RF: otsenka ekonomicheskogo effekta (poter') [The actual incidence of the population in the rf subject: assessment of economic effect (losses)]. Gigiena $i$ sanitariya, 2013, no. 6, pp.74-78 (in Russian).

6. Shakhanina I.L., Yasinskii A.A. Kontseptsiya opredeleniya ekonomicheskoi effektivnosti vaktsinoprofilaktiki [The concept of Determining the Cost-Effectiveness of Vaccination]. Epidemiologiya $i$ Vaktsinoprofi-laktika, 2010, vol. 53, no. 4, pp. 74-80 (in Russian).

7. Yushchuk N.D., Martynov Yu.V. Epidemiologiya: Ucheb. Posobie [Epidemiology: a manual]. 2-ndeds., Moscow, Meditsina, Publ., 2003, 448 p. (in Russian).

8. Assessing the socio-economic impacts of Ebola Virus Disease in Guinea, Liberia and Sierra Leone: The Road to Recovery. 2014, 72 p. Available at: http://www.africa.undp.org/content/dam/rba/docs/Reports/EVD\%20Synthesis\%20Report\%2023Dec2014.pdf(10.06.2017).

9. Assessing the International Spreading Risk Associated with the 2014

West African Ebola Outbreak. PLOS: Current Outbreak, 2014. Available at: http://currents.plos.org/outbreaks/article/assessing-the-international-spreading-riskassociated-with-the-2014-west-african-ebola-outbreak (10.06.2017).

10. Faye O., Boëlle P.Y., Heleze E., Faye O., Loucoubar C., Magassouba N., Soropogui B., Keita S., Gakou T., Bah el H.I., Koivogui L., Sall A.A., Cauchemez S. Chains of transmission and control of Ebola virus disease in Conakry, Guinea, in 2014: an observational study. Lancet, 2015, vol. 15, no. 3, pp. 320-326.

11. Cost of the Ebola Epidemic: CDC Document, 2016. Available at: https://www.cdc.gov/vhf/ebola/pdf/impact-ebola-economy.pdf (03.03.2017). 
12. Ebola data and statistics. World Health Organization. Available at: http://apps.who.int/gho/data/node.ebola-sitrep.ebola-country?lang=en (10.06.2017).

13. Baize S., Pannetier D., Oestereich L., Rieger T., Koivogui L., Magassouba N., Soropogui B., Sow M.S., Keïta S., De Clerck H., Tiffany A., Dominguez G., Loua M., Traoré A., Kolié M., Malano E.R., Heleze E., Bocquin A., Mély S., Raoul H., Caro V., Cadar D., Gabriel M., Pahlmann M., Tappe D., Schmidt-Chanasit J., Impouma B., Diallo A.K., Formenty P., Van Herp M., Günther S. Emergence of Zaire Ebola virus disease in Guinea. N. Engl. J. Med, 2014, vol. 371, no. 15, pp. 1418-1425. DOI: 10.1056/NEJMoa1404505

14. Frasso G., Lambert P. Bayesian inference in an extended SEIR model with nonparametric disease transmission rate: an application to the Ebola epidemic in Sierra Leone.Biostatistics, 2016, vol. 17, no. 4, pp.779-792.

15. Kermack W., McKendrick A. A contribution to the mathematical theory of epidemics. Proc. R. Soc. London, 1927, A 115, 700-721.

16. Niels G. Becker Statistical studies of infectious disease incidence. J. R. Statist. Soc. B, 1999, vol. 61, part 2, pp. 287-307.

17. Shen M., Xiao Ya., Rong L. Modeling the effect of comprehensive interventions on Ebola virus transmission. Scientific Reports. 5, 2015, Article number: 15818. DOI: 10.1038/srep15818. Available at: http:/www.nature. com/articles/srep15818 (10.06.2017).

18. Socio-Economic Impact of Ebola Virus Disease in West African Countries: A call for national and regional containment, recovery and prevention. United Nations Development Group - Western and Central Africa. 2015, 116 p. Available at: http://www.africa.undp.org/content/dam/rba/docs/Reports/ebola-west-africa.pdf (10.06.2017).

19. The Economic Impact of the 2014 Ebola Epidemic: Short and Medium Term Estimates for Guinea, Liberia, and Sierra Leone. World Bank. 2014, 29 p. Available at: https://www.globalsecurity.org/security/library/report/2014/2014-ebola-economicimpact.pdf (10.06.2017).

20. Legrand J., Grais R.F., PBoelle.Y., Valleron A.J., Flahault A. Understanding the dynamics of Ebola epidemics.Epidemiology and Infection, 2007, vol. 135, no. 4, pp. 610-621.

21. Update on the Economic Impact of the 2014-2015 Ebola Epidemic on Liberia, Sierra Leone, and Guinea. World Bank Group, 2015, 19 p. Available at: https://openknowledge.worldbank.org/bitstream/handle/10986/

21965/95804.pdf (10.06.2017).

Smolensky V.Yu., Shur P.Z., Suvorov D.V., Goleva O.I., Safronov V.A., Khrushcheva E.V., Vindokurov I.V. Methodological approaches to assessing economic effects of activities aimed at minimizing health risks related to extremely dangerous infections. Health Risk Analysis, 2017, no. 4, pp. 32-41. DOI: 10.21668/health.risk/2017.4.03.eng 
Received: 22.09.2017

Accepted: 21.12.2017

Published: 30.12.2017 


\title{
RISK ASSESSMENT PRACTICE IN HYGIENIC AND EPIDEMIOLOGICAL STUDIES
}

UDC $613.3(470.11)$

DOI: $10.21668 /$ health.risk/2017.4.04.eng

\section{NON-CARCINOGENIC RISK FOR CHILDREN POPULATION HEALTH IN KAZAN CAUSED BY FOOD PRODUCTS AND FOOD RAW MATERIALS CONTAMINATION*}

\author{
S.F. Fomina, N.V. Stepanova \\ Kazan Federal University, Fundamental Medicine and Biology Institute, 18 Kremlevskaya street, Kazan, 420008, \\ Russian Federation
}

The paper dwells on results of assessing non-carcinogenic risk for children health in Kazan caused by consumption of food products contaminated with chemicals. Research was performed in two stages (2007-2010 and 2011-2014) on children aged 3-6. Actual nutrition of children was examined via questioning and timingweighing techniques. Daily doses were calculated allowing for regional exposure parameters at median (Me) and 95-th percentile level. We detected high non-carcinogenic risk at 95-th percentile level for methyl-mercury (3.89 and 3.33 in both periods correspondingly); high and intolerable for As (10.67 in the first period). We determined organs and systems in a body which were under greatest toxic effects. Alerting level of noncarcinogenic risk for central nervous system $(H I=3.03)$ was detected in the first period at median level. In 2007-2010 we detected the following high non-carcinogenic risks at the 95-th percentile level of a danger coefficient for children: non-carcinogenic risk for central nervous system $(H I=12.20)$, hormonal system $(H I=12.87)$, immune system $(H I=11.72)$, and alerting risk for development $(H I=4.03)$. In 2011-2014 the following systems were most prone to overall toxic impacts: central nervous system and development $(H I=4.02$ and 3.98 correspondingly). Non-carcinogenic effects risk over 2007-2011 for hormonal system (64\%), central nervous system (79\%), and immune system (91\%) was caused mostly by food products contamination with As. As for 2011-2014, the greatest risk factor was Pb introduction, (46\%) for hormonal system, and (57\%) for central nervous system.

Key words: chemical contaminants, regional exposure factors, children, share contribution, noncarcinogenic risk, critical organs, critical systems in a body.

Food products safety is becoming more and more vital each year as provision of proper food raw materials and food products quality is one of the basic factors which determine absence of human health risks when food is consumed. Nowadays food products contain various quantities of contaminants, in some cases, in doses mostly lower than the fixed hygienic standards $[3,7]$. Long-term chemical loads with low intensity are one of the most sig- nificant health risk factors which make for decrease in a body resistance to impacts exerted by other unfavorable ecological and socially determined environmental factors $[1,16]$. Therefore, it is necessary to provide surveillance over food products safety, to examine possible negative influence exerted by low doses of foreign substances on children's health; these theoretical and practical hygienic tasks are seen as truly vital. Children are a contingent most

(C) Fomina S.F., Stepanova N.V., 2017

Suryana F. Fomina - post-graduate student (e-mail: isuryana@mail.ru; tel.: +7 (917) 900-94-56).

Natalya V. Stepanova - Doctor of Medicine, Professor (e-mail: stepmed@mail.ru; tel.: + 7 (917) 399-99-07).

* The work was accomplished due to a grant given to Kazan Federal University for performing a state task in scientific research sphere No. 19.9777.2017/8.9 
sensitive to unfavorable impacts exerted by environmental factors, so children's health can be a reliable indicator showing whether ecological situation in a region is safe or not.

Our review of publications on risk assessment in Russia has revealed that most issues these paper dwell on are related to exposure assessment uncertainties and absence of regional, national, and age discrepancies in exposure factors and sensitivity to carcinogens $[4,13]$. Children under 6 , due to their functional characteristics peculiarities are known to be most vulnerable in terms of exposure to chemicals [8].

Our research goal was to assess noncarcinogenic risk for 3-6 year old children's health depending on food products loads with contaminants in the region..

Our research was performed in two periods: 2007-2010 and 2011-2014. We examined actual nutrition of children aged 3-6 years incorporating the following: examination of individual and family nutrition (questioning); examination of nutrition in pre-school children facilities where a child received full or partial ration (timing-weighing technique). Actual nutrition which children received in a municipal pre-school children facility "Children's kindergarten No. 146" in Kazan was analyzed monthly via reports on food products consumption (cumulative lists analysis), as well as selectively via menu sheets analysis. Children's nutrition assessment was appended with the results obtained via parents' questioning on family nutrition at weekends and in the evening on workdays. To calculate exposure, we applied data on the examined chemicals content in food products and data on food products consumption by children on the basis of the median and 95\% percentile in conformity with $\mathrm{Me}$ thodical Guidelines 2.3.7.2519-09 "De- termination of exposure on population and risk assessment for chemical contaminants in food products" [2]. Noncarcinogenic risk was assessed as per results of our research on analyzing $\mathrm{Pb}, \mathrm{Cd}$, As, and $\mathrm{Hg}$ contents in various food products. The analysis was performed in a certified laboratory at Tatarstan Republic Center for Hygiene and Epidemiology in accordance with the 2.1.10.1920-04 "Guide to health risk assessment when exposed to chemicals polluting the environment" and the US Environmental Protection Agency. General toxic effects were characterized on the basis of hazard quantifications (HQ) for specific chemicals and aggregate hazardous indexes (HI) for chemicals with similar impacts $[5,17]$. HI values ranging from 1.1 to 3.0 were taken as permissible noncarcinogenic impacts; HI values ranging from 3 to 6 were considered to be alerting risk level; HI values higher than 6 were considered to be high risks [6].

Assessment results showed that $\mathrm{Pb}$ made the greatest contribution into the aggregate exposure in both examined periods (2007-2010 and 2011-2014); it was introduced with food products $(69.34 \%$ and $85.91 \%$ at the median level and $50.93 \%$ and $87.77 \%$ at $95 \%$-percentile level). As (arsenic) aggregate exposure took the second place in 2007-2010 (14.13\% at the median level and $34.28 \%$ at 95\%-percentile level) (Table 1).

In 2011-2014 exposure share of $\mathrm{Pb}$ which penetrated children's bodies with food products was 1.7 times higher than in 2007-2010 at the median level and 95\% percentile level.

Grain, cereals and bakery were products with the highest $\mathrm{Pb}$ content and they made the greatest contribution into the aggregate exposure in both periods $(31.08 \%$ and 
$31.63 \%$ at the median level, $44.24 \%$ and $35.02 \%$ at $95 \%$-percentile level); meat and meat products, poultry, and eggs also contributed $(28.85 \%$ and $30.22 \%$ at the median level, $18.03 \%$ and $22.58 \%$ at $95 \%$ - percentile level); milk and dairy products took the third place $(16.66 \%$ and $18.94 \%$ at the median level, $14.31 \%$ and $20.42 \%$ at 95\%-percentile level).

Table 1

Assessment results for exposure to chemical contaminants introduced with food products

\begin{tabular}{|c|c|c|c|c|c|c|c|c|}
\hline \multirow{3}{*}{ Contaminant } & \multicolumn{4}{|c|}{ 2007-2010 } & \multicolumn{4}{|c|}{ 2011-2014 } \\
\hline & \multicolumn{2}{|c|}{$\begin{array}{l}\text { Exposure } \\
\mathrm{mg} / \mathrm{kg}^{*} \text { day }\end{array}$} & \multicolumn{2}{|c|}{$\begin{array}{c}\text { Contribution into } \\
\text { aggregate exposure, } \%\end{array}$} & \multicolumn{2}{|c|}{$\begin{array}{l}\text { Exposure } \\
\mathrm{mg} / \mathrm{kg}_{*} \text { day }\end{array}$} & \multicolumn{2}{|c|}{$\begin{array}{l}\text { Contribution into ag- } \\
\text { gregate exposure, } \%\end{array}$} \\
\hline & median & $\begin{array}{l}95 \% \text { per- } \\
\text { centile }\end{array}$ & median & $\begin{array}{c}35 \% \text { percen } \\
\text { tile }\end{array}$ & median & $\begin{array}{l}95 \% \text { per- } \\
\text { centile }\end{array}$ & median & $\begin{array}{c}95 \% \text { percen } \\
\text { tile }\end{array}$ \\
\hline $\mathrm{Pb}$ & 0,00952 & 0,03329 & 69,34 & 50,93 & 0,01694 & 0,05072 & 85,91 & 87,77 \\
\hline $\mathrm{Cd}$ & 0,00154 & 0,00710 & 11,22 & 10,86 & 0,00246 & 0,00580 & 12,47 & 10,04 \\
\hline As & 0,00194 & 0,02241 & 14,13 & 34,28 & 0,00006 & 0,00008 & 0,3 & 0,01 \\
\hline $\mathrm{Hg}^{1}$ & 0,00055 & 0,00218 & 4,00 & 3,33 & 0,00016 & 0,00093 & 0,81 & 1,61 \\
\hline Methyl $\mathrm{Hg}^{2}$ & 0,00018 & 0,00039 & 1,31 & 0,6 & 0,00010 & 0,00033 & 0,51 & 0,57 \\
\hline Sum & 0,01373 & 0,06537 & 100,0 & 100,0 & 0,01972 & 0,05778 & 100,0 & 100,0 \\
\hline
\end{tabular}

Note (here and further on):

${ }^{1}$ Exposure dose for $\mathrm{Hg}$ is calculated for food products groups without fish and non-fishery trade objects.

${ }^{2}$ Exposure dose for methyl $\mathrm{Hg}$ is calculated for fish and non-fishery trade objects.

The greatest contribution into exposure to $\mathrm{Cd}$ in 2007-2010 was made by the following groups of products: grain, cereals, and bakery $(42.63 \%$ at the median level and $39.81 \%$, at 95\%-percentile level); fish and non-fishery trade objects $(18.47 \%$ and $21.51 \%$, correspondingly); fruit and vegetables $(15.19 \%$ and $14.11 \%$, correspondingly). In 2011-2014 the greatest contribution into exposure to $\mathrm{Cd}$ was made by milk and dairy products $(64.57 \%$ at the median level and $27.35 \%$, at $95 \%$-percentile level), as well as grain, cereals, and bakery (17.82\% at the median level and $40.17 \%$, at $95 \%$-percentile level). The greatest contribution into exposure to $\mathrm{Hg}$ in both periods was made by meat and meat products, poultry, and eggs $(28.78 \%$ and $36.86 \%$ at the median level and $20.73 \%$ and $28.84 \%$, at 95\%-percentile level); grain, cereals, and bakery $(28.52 \%$ and $18.45 \%$ at the median level and $40.49 \%$ and $42.74 \%$, at $95 \%$ percentile level); fish and non-fishery trade objects $(18.55 \%$ and $28.79 \%$ at the median level and $10.94 \%$ and $19.80 \%$ at $95 \%$ percentile level). In 2007-2010 milk and dairy products also contributed into exposure to $\mathrm{Hg}(20.04 \%$ at the median level, $21.48 \%$ at $95 \%$-percentile level).In 20072010 substantial contributions into overall exposure to As were detected for fish and non-fishery trade objects $(83.13 \%$ at the median level, $77.44 \%$ at $95 \%$-percentile level); and in 2011-2014, for milk and dairy products $(57.78 \%$ at the median level, $64.37 \%$ at 95\%-percentile level), as well as for sugar and confectionary $(42.22 \%$ at the median level, $35.63 \%$ at 95\%-percentile level). It can be explained by the fact that in 2011-2014 we didn't de- 
tect any As content in other groups of food products.

As most $\mathrm{Hg}$ in fish is actually methyl $\mathrm{Hg}$, so, as per recommendations given by United Nations Environment Programme (UNEP) and $\mathrm{WHO}$, in $2008 \mathrm{Hg}$ content in fish and non-fishery trade objects was recalculated in to methyl $\mathrm{Hg}$. Methyl $\mathrm{Hg}$ is easily absorbed into a body via the gastrointestinal tract and has higher exposure levels. Pregnant women and children are more susceptible to it even when exposure is rather low. We should also note that non-organic $\mathrm{Hg}$ is a food contaminant but exposure to it is considered to be less significant in comparison with exposure to methyl $\mathrm{Hg}[11,15,17,18]$.

We applied officially recommended data on reference (safe) doses (RfD) under chronic exposure on critical body organs and systems as criteria for assessing noncarcinogenic risks for children's health caused by the examined chemicals introduced with food products (Table 2).

Risk characteristics revealed that values obtained for methyl $\mathrm{Hg}$ at the median level, $\mathrm{Cd}$ and $\mathrm{Hg}$, at 95\%-percentile level in the first period, were higher than the reference value being equal to 1.0. Hazard quantification for methyl $\mathrm{Hg}$ at $95 \%$ percentile level was higher than 3.0 which meant average risk. Risk as per As turned out to be extremely high (hazard quantification was higher than 10.0). In the second period hazard quantification for methyl $\mathrm{Hg}$ at 95\%-percentile level was also higher than 3.0. Non-carcinogenic risks caused by exposure to $\mathrm{Pb}$ in the first period, and to $\mathrm{Pb}, \mathrm{Cd}$, and $\mathrm{Hg}$, in the second period didn't exceed permissible levels (Table 3 ).

The examined chemical contaminants ( $\mathrm{Pb}, \mathrm{Cd}, \mathrm{As}, \mathrm{Hg}$, and methyl $\mathrm{Hg}$ ), detected in the analyzed food products in 20072010 and 2011-2014, can possibly cause various adverse effects in a body [10, 12].

Hazard indexes (HI) calculated on the basis of the median hazard quantification values were equal to 3.0 in the first period which meant risk was average, and they were lower than 3.0 in the second period which meant risk was permissible.

Table 2

Non-carcinogenic hazard parameters for the examined chemicals at oral introduction

\begin{tabular}{|c|c|c|c|c|}
\hline \multirow[b]{2}{*}{ CAS* } & \multirow[b]{2}{*}{ Chemical } & \multicolumn{2}{|r|}{ Non-carcinogenic effects } & \multirow[b]{2}{*}{ Data source } \\
\hline & & $\begin{array}{l}R f D, \\
m g / k g\end{array}$ & Critical organs and systems & \\
\hline 7439-92-1 & $\mathrm{Pb}$ & 0,035 & $\begin{array}{l}\text { Nervous system, blood making organs, cardiovas- } \\
\text { cular system, reproductive system, urogenital sys- } \\
\text { tem }\end{array}$ & P.2.1.10.1920-04 [5] \\
\hline $7440-43-9$ & $\mathrm{Cd}$ & 0,001 & Urogenital system, kidneys & IRIS [14] \\
\hline $7440-38-2$ & As & 0,0003 & $\begin{array}{l}\text { Central nervous system, nervous system, cardi- } \\
\text { ovascular system, immune system, hormonal } \\
\text { system, gastrointestinal tract }\end{array}$ & IRIS [14] \\
\hline 7439-97-6 & $\mathrm{Hg}$ & 0,0003 & $\begin{array}{l}\text { Immune system, kidneys, central nervous sys- } \\
\text { tem, reproductive system, hormonal system }\end{array}$ & $\begin{array}{c}\text { P.2.1.10.1920-04 [5]; } \\
\text { WHO/UNEP, } 2008 \\
{[18]}\end{array}$ \\
\hline & Methyl Hg & 0,0001 & $\begin{array}{l}\text { Central nervous system, kidneys, nervous sys- } \\
\text { tem }\end{array}$ & $\begin{array}{l}\text { WHO/UNEP, } 2008 \\
{[18]}\end{array}$ \\
\hline
\end{tabular}

Note: ${ }^{*}$ - unique numerical identifier for chemical substances 
Table 3

Non-carcinogenic risks of functional disorders in nervous system for children in Kazan at oral contaminants introduction with food products

\begin{tabular}{|c|c|c|c|c|c|c|c|c|}
\hline \multirow{3}{*}{ Contaminants } & \multicolumn{4}{|c|}{$2007-2010$} & \multicolumn{4}{|c|}{ 2011-2014 } \\
\hline & \multicolumn{2}{|c|}{$\begin{array}{c}\text { Hazard } \\
\text { quantifications (HQ) }\end{array}$} & \multicolumn{2}{|c|}{$\begin{array}{c}\text { Contribution into HI, } \\
\%\end{array}$} & \multicolumn{2}{|c|}{$\begin{array}{l}\text { Hazard quantifica- } \\
\text { tions (HQ) }\end{array}$} & \multicolumn{2}{|c|}{$\begin{array}{c}\text { Contribution into HI, } \\
\%\end{array}$} \\
\hline & Median & $\begin{array}{l}95 \% \text { per- } \\
\text { centile }\end{array}$ & Median & $\begin{array}{l}95 \% \text { percen- } \\
\text { tile }\end{array}$ & Median & $\begin{array}{l}95 \% \text { percen- } \\
\text { tile }\end{array}$ & Median & $\begin{array}{l}95 \% \text { percen- } \\
\text { tile }\end{array}$ \\
\hline $\mathrm{Pb}$ & 0,039 & 0,136 & 1,28 & 1,11 & 0,069 & 0,207 & 6,058 & 20,254 \\
\hline As & 0,925 & 10,670 & 30,53 & 87,24 & 0,029 & 0,039 & 2,546 & 3,816 \\
\hline $\mathrm{Hg}$ & 0,260 & 1,036 & 8,57 & 8,47 & 0,078 & 0,442 & 6,848 & 43,249 \\
\hline Methyl Hg & 1,806 & 0,389 & 59,63 & 3,18 & 0,963 & 0,334 & 84,548 & 32,681 \\
\hline Total (HI) & 3,029 & 12,231 & 100,00 & 100,00 & 1,139 & 1,022 & 100,00 & 100,00 \\
\hline
\end{tabular}

In the first period children ran alerting non-carcinogenic risk for the central nervous system at the median level (HI was equal to 3.03), and high risk at 95\% percentile level (HI was equal to 12.2). We also detected high non-carcinogenic risk for the hormonal system at the $95 \%$ percentile level $(\mathrm{HI}=12.87)$, immune system $(\mathrm{HI}=11.72)$, and alerting risk for the overall development $(\mathrm{HI}=4.03)$. In 20112014 the central nervous system and the overall development were most exposed to overall toxic effects $(\mathrm{HI}=4.02$ and 3.98 correspondingly). In 2007-2010 noncarcinogenic risks for the hormonal system (64\%), central nervous system $(79 \%)$, and immune system (91\%) were mostly determined by food products contamination with As; and in 2011-2014, with $\mathrm{Pb}$, the hormonal system $(46 \%)$, central nervous system (57\%).

Given high non-carcinogenic risk at 95\%-percentile level caused by As and methyl Hg, as well as a child's body peculiari- ties (greater quantities of products and chemicals being introduced as per $1 \mathrm{~kg}$ of body weight than in adults), it is necessary to enhance surveillance over the examined contaminants contents in food products. It is necessary to assess exposure for specific age groups of children allowing for their behavior at a different age, and peculiarities of a region they live in [9]. Some facts are being discovered that allow to suggest that increased risks of certain diseases evolvement in adults, notably, cancer and heart diseases, can be partly caused by early exposure to certain chemicals from the environment in childhood [13].

Risk analysis allowing for local factors and age differences in exposure to chemicals introduced orally with food products revealed that standards values application in risk assessment methodology causes underestimation of actual children health risks. 


\section{References}

1. Rakhmanin Yu.A., Sinitsyna O.O., Avaliani S.L., Novikov S.M. Aktualizirovannye ekologicheskie factory riska zdorov'yu naseleniya i puti sovershenstvovaniya ego otsenki [Actualized ecological population health risk factors and ways of improving efficiency of its assessment]. Aktual'nye problemy bezopasnosti i analiza riska zdorov'yu naseleniya pri vozdeistvii faktorov sredy obitaniya: materialy VI Vserossiiskoi nauchno-prakticheskoi konferentsii s mezhdunarodnym uchastiem [Vital issues of safety and population health risk analysis under exposure to environmental factors: Materials of the VI Russian Theory and Practice Conference with international participation]. Perm', 2015, pp. 12-21 (in Russian).

2. Opredelenie ekspozitsii i otsenki riska vozdeistviya khimicheskikh kontaminantov pishchevykh produktov na naselenie: metodicheskie ukazaniya 2.3.7.2519-09. [Exposure determination and assessment of risks caused by effects exerted on population by chemical contaminants in food products: methodical guidelines 2.3.7.2519-09.]. Moscow, Federal'nyi tsentr gigieny i epidemiologii Rossii, Publ., 2010, 27 p. (in Russian).

3. Onishchenko G.G., Litvinova O.S., Tutel'yan V.A. Otsenka rezul'tatov monitoringa bezopasnosti pishchevykh produktov v Rossiiskoi Federatsii. Mikotoksiny [Evaluation of the results of monitoring food safety in Russia. Mycotoxins]. Voprosy pitaniya, 2010, vol. 79, no. 5, pp. 24-28 (in Russian).

4. Stepanova N.V., Valeeva E.R., Fomina S.F., Ziyatdinova A.I. Otsenka nekantserogennogo riska dlya zdorov'ya detskogo naseleniya pri potreblenii pit'evoi vody [Assessment of noncarcinogenic risk for the health of the child population under the consumption of drinking water]. Gigiena i sanitariya, 2016, vol. 95, no. 11, pp. 1079-1083 (in Russian).

5. Rukovodstvo po otsenke riska dlya zdorov'ya naseleniya pri vozdeistvii khimicheskikh veshchestv, zagryaznyayushchikh okruzhayushchuyu sredu R 2.1.10.1920-04 [Guide to health risk assessment when exposed to chemicals polluting the environment 2.1.10.1920-04]. Moscow, Federal'nyi tsentr gossanepidnadzora Minzdrava Rossii, Publ., 2004, 143 p. (in Russian).

6. Avaliani S.L., Novikov S.M., Shashina T.A., Kislitsin V.A. Razvitie metodologii otsenki riska s uchetom garmonizatsii s mezhdunarodnymi trebovaniyami [Risk assessment methodology development allowing for harmonization with international requirements]. Opyt ispol'zovaniya metodologii otsenki riska zdorov'yu naseleniya dlya obespecheniya sanitarnoepidemiologicheskogo blagopoluchiya: materialy Vserossiiskoi nauchno-prakticheskoi konferentsii s mezhdunarodnym uchastiem [Experience of population health risk assessment application for providing sanitary and epidemiologic welfare: Materials of Russian Theory and Practice Conference with international participation]. Angarsk, RIO ATA, Publ., 2012, pp. 12-16 (in Russian).

7. Stepanova N.V., Smirnov V.M., Khamitova R.Ya. Otsenka khimicheskoi bezopasnosti pishchevykh produktov [Evaluation of Chemical Safety of Foodstuffs]. Kazanskii meditsinskii zhurnal, 2005, no. 5, pp. 419-422 (in Russian).

8. Stepanova N.V., Fomina S.F. Novye napravleniya v metodologii otsenki riska dlya zdorov'ya naseleniya - otsenka detskogo riska (glava 1) [New trends in methodology for population health risk assessment - assessing risks for children (Chapter 1)]. Tendentsii i innovatsii fundamental'nykh i prikladnykh nauk; kniga 3. In: I.B. Krasina, ed. Stavropol', Logos, Publ., 2016, 162 p. (in Russian).

9. Unguryanu T.N. Gigienicheskaya otsenka kachestva pishchevykh produktov v gorode Novodvinske [Hygienic assessment of food products quality in Novodvinsk]. Ekologiya cheloveka, 2010, no. 12, pp. 10-17 (in Russian).

10. Fetter V.V. Otsenka riska dlya zdorov'ya naseleniya khimicheskoi kontaminatsii produktov pitaniyai prodovol'stvennogo syr'ya [Human health risk assessment of the chemical contamination of food products and raw foods]. Health Risk Analysis, 2013, no. 4, pp. 54-63 (in Russian). 
11. Buchanan S., Anglen J., Turyk M. Methyl mercury exposure in populations at risk: Analysis of NHANES 2011-2012. Environmental Research, 2015, vol. 140, pp 56-64. Available at: http: //www.sciencedirect.com/science/article/pii/S0013935115000766 (10.08.2017).

12. Dietary exposure to inorganic arsenic in the European population. European Food Safety Authority (EFSA), 2014, vol. 12, no. 3. DOI: 10.2903/j.efsa.2014.3597. Available at: http: //onlinelibrary.wiley.com/doi/ 10.2903/j.efsa.2014.3597/references (15.08.2017).

13. Firestone M. Protecting children from environmental risks throughout each stage of their childhood. Journal of Exposure Science and Environmental Epidemiology, 2010, vol. 20, pp. 227-228.

14. Integrated Risk Information System (IRIS). IRIS Assessments: A to Z QuickList of Chemicals. U.S. Environmental Protection Agency. Available at: https://cfpub.epa.gov/ncea/iris drafts/simple list.cfm (09.08.2017).

15. Sirot V., Guérin T., Mauras Y., Garraud H., Volatier J.-L., Leblanc J.-Ch. Methyl mercury exposure assessment using dietary and biomarker data among frequent seafood consumers in France: CALIPSO study.Eighth International Conference on Mercury as a Global Pollutant: Human Health and Exposure to Methylmercury, 2008, vol. 107, pp. 30-38. Available at: http: //www.sciencedirect.com/science/article/pii/S0013935107002484 (11.08.2017).

16. Jae-Yeon J., Soo-Nam J., So-Yeon K., Hyung-Nam M. [et al]. Overview of the Development of the Korean Exposure Factors Handbook. Journal of Preventive Medicine and Public Health, 2014, vol. 47, no. 1, pp. 1-6. Available at: https://www.ncbi.nlm.nih.gov/pmc/articles/PMC3930803/ (11.08.2017).

17. U.S. EPA. Exposure Factors Handbook 2011 Edition (Final Report).U.S. Environmental Protection Agency. Washington, DC, EPA/600/R-09/052F, 2011. Available at: https://cfpub.epa.gov/ncea/risk/recordisplay.cfm?deid=236252 (10.08.2017).

18. UNEP DTIE Chemicals Branch and WHO Department of Food Safety, Zoonoses and Foodborne Diseases. Guidance for Identifying Populations at Risk from Mercury Exposure.Geneva, $\quad$ Switzerland, 2008, 167 p. Available at: http://www.who.int/foodsafety/publications/risk-mercury-exposure/en/ (09.08.2017).

Fomina S.F., Stepanova N.V. Non-carcinogenic risk for children population health in Kazan caused by food products and food raw materials contamination. Health Risk Analysis, 2017, no. 4, pp. 42-48. DOI: 10.21668/health.risk/2017.4.04.eng

Received:04.09.2017

Accepted: 02.12.2017

Published: 30.12.2017 
UDC [614.79: 613.63: 615.9]+632.954

DOI: 10.21668/health.risk/2017.4.05.eng

\title{
HYGIENIC ASSESSMENT OF RISK CAUSED BY APPLICATION OF GRAMINIS KE AND RINKOR VG HERBICIDES
}

\author{
M.M. Vasileva, A.A. Popel, E.S. Yurkevich, I.I. Ilyukova
}

Scientific-practical Hygiene Center, 8 Akademicheskaya Str., Minsk, 220012, Republic of Belarus

Our research goal was to perform hygienic assessment of risks caused by Graminis KE and Rinkor VG herbicides for people working with them. We applied sanitary-hygienic and toxicological research techniques in our work in full conformity with valid technical regulatory documents and guidelines. We set the following research tasks: to analyze literature and information sources; to perform primary toxicological assessment of preparatory herbicides and study their acute toxicity

together with sensitizing effects at intragastric introduction, cutaneous application, and inhalation exposure on laboratory animals; to examine herbicides cumulative effects and calculation their cumulation coefficient; to examine working conditions during a natural experiment when Graminis KE and Rinkor VG herbicides were applied and calculate risks for workers; to work out scientifically grounded recommendations on their safety application in agriculture.

The examined herbicides, Graminis KE and Rinkor VG, are classified as substances with the 3rd hazard degree as per their toxicometric parameters (moderately hazardous substances). Calculated risks of complex (inhalant and dermal) exposure to Gramins KE and Rinkor VG herbicides for workers (operators who refills them and those who spray plants with them) when they are applied in agriculture don't exceed acceptable levels (are less than 1). Our work results allow to enrich a set of plant protectors which are applied in the country and to use such preparations in agriculture which are the least harmful for health and the environment. Application of Graminis KE and Rinkor VG herbicides will help to increase crops productivity.

Key words: hygienic risk assessment, herbicides, primary toxicological assessment, acute toxicity, sensitizing effects, cumulative properties, cumulation coefficient, agriculture.

History of agriculture gives us an deniable proof that such extermination activities as hand weeding, cultivation, and harrowing, had always been playing the leading role in fighting against weeds. But then herbicides were invented and it led to a real revolution in agriculture and old techniques to a certain extent were replaced with new ones. Agricultural workers all over the world have been applying herbicides for more than 60 years completely relying on them; we can say that herbicides are now among most widely spread agricultural chemicals $[1,2,4,9]$.

Contemporary crop production involves certain tasks; for example, it is vital to achieve maximum possible productivity of crops but ensuring here that agricultural products don't contain any substances which can be toxic for people and animals, for example, pesticides [5].

Crops protection means are mostly chemicals which are created and applied for fighting weeds and pests. Pesticides appli-

(C) Vasileva M.M., Popel A.A., Yurkevich E.S., Ilyukova I.I., 2017

Marina M. Vasileva - junior researcher at Preventive and Ecological Toxicology Laboratory (e-mail: vasmm11@gmail.com; tel.: +375 (17) 284-13-82).

Alina A. Popel - junior researcher at Preventive and Ecological Toxicology Laboratory (e-mail: bublik170891@mail.ru; tel.: +375 (17) 284-13-82).

Elena S. Yurkevich - Candidate of Medical Sciences, leading researcher at Preventive and Ecological Toxicology Laboratory (e-mail: yrkevich.elena@gmail.com; tel.: +375 (17) 284-13-82).

Irina I. Ilyukova - Candidate of Medical Sciences, Head of Preventive and Ecological Toxicology Laboratory (e-mail: toxlab@mail.ru; tel.: +375 (17) 292-60-27). 
cation allows to produce stable crops and to limit spread of infections which are transferred by carrying agents, for example, malaria and epidemic typhus. However, unconsidered application of pesticides has also negative consequences and results in greater resistance to them among organisms, especially insects; it can kill natural enemies of pests and other beneficial animals. Pesticides contaminate the environment and are a threat for human health. Herbicides take the first place among crop protectors as per applied quantities [7].

Herbicides is a commonly and worldwide used name for chemical crop protectors; it consists of two basic words: herb for plant and cide for eliminate, that is a planteliminating substance [3].

About 4.5 million tons of various herbicides are produced annually all over the world; they are intensively put into soils, especially in the regions with highly developed agriculture, and, consequently, exert negative influence on the environment in them. Herbicides are accumulated in soils. They can be washed out of them, penetrate natural water reservoirs and then they can be introduced into human and animals bodies. Physical and chemical absorption, biological and enzymatic destruction play their own role in soils self-purification from poisons; however, some toxins with systemic effects can penetrate into crops and create threats for food and fodders quality [13$15]$.

Chemical components are known to inhibit live activity of soils biological component, namely bacteria, fungi, ray fungi, algae, rhizopod, flagellates, etc., living in them and participating in humus creation. As these soils inhabitants perish, it makes soils less nutritious. And effects exerted by chemicals can be rather long-term [16].

Herbicides, in comparison with other crop protectors, are more phyto-toxic which is characteristic for substances with weak selective effects.

Sometimes substances with wide range of effects eliminate not only weeds but also useful cultures which are related to a target object (the same family etc.). For example, when beetroot crops are treated, certain substances kill not only lamb's-quarters, but also beetroot itself; when herbicides exert their impacts on monocotyledonous weeds, they can also harm cultivated cereal crops. To preserve a cultivated culture, agricultural workers usually choose either substances which beneficial crops are resistant to, or those which have maximum selective effects $[11,12,17]$.

Growing concern related to pesticides abuse led to creation of basic rules for their application accepted in many countries all over the world. These rules comprise all the aspects of their distribution: transportation, storage, packing utilization, and maximum permissible residual quantities.

There is a law issued in the EU which forbids application of highly toxic pesticides, including carcinogenic and mutagenic substances which cause reproductive function disorders and endocrine systems disorders, and which are persistent and capable of biological accumulation.

Experts allow for high threats of herbicides contamination, both during their application and manufacturing and transportation and therefore recommend to apply maximum safe or less toxic pesticides, or try to resort to non-chemical alternative pests-fighting techniques, such as cultivating, biological preparations (for example, pheromones and microbe pesticides), genetic engineering, genetic modifications, wastes composting, etc. These techniques are becoming more and more popular and are often less dangerous than conventional chemical pesticides. 
Therefore, nowadays it is advisable to offer a wide choice of promising crop protectors to agricultural workers; these crop protectors will allow to minimize negative influence on population health and the environment and to lower economic damage related to it; they will also give grounds for manufacture of ecologically safe food products.

In order to prevent negative consequences of herbicides application, to give scientific foundations for risks caused by it in real life conditions, and to develop measures aimed at herbicides safe distribution, it is necessary to perform toxicological and sanitary-chemical examinations of new preparations as it will help to minimize negative influence exerted by them on population health and the environment and to lower economic damage related to it, and to achieve their maximum efficiency in fighting against weeds growing on fields with agricultural crops.

Our research goal was to perform hygienic assessment of risks caused by two herbicides, Graminis, CE (concentrated emulsion) and Rinkor, WG (water-soluble granules) for workers involved in their application.

We solved the following tasks in the course of our research: to analyze literature and information sources; to make primary toxicological assessment of herbicides preparatory forms with experiments on laboratory animals aimed at studying acute toxicity at intragastric introduction, cutaneous application, and inhalation exposure, and sensitizing effects caused by it; to examine herbicides cumulative properties and calculate cumulation coefficient; to study work- ing conditions during a natural experiment at Graminis CE and Rinkor WG herbicides application and calculate risks for workers; to develop scientifically grounded recommendations on their safe application in agriculture.

Data and methods. We applied sanitary-hygienic and toxicological research techniques (acute toxicity at intragastric introduction, cutaneous application, and inhalation exposure; sensitizing effects; cumulative properties) in conformity with valid technical regulatory legal acts and guidelines $[6,8]$. Results were statistically processed with the use of MS Excel XP and Statistica 6.0 software.

Results and discussion. We studied acute toxicity at intragastric introduction in the experiment in accordance with the Instruction No. 1.1.11-12-35-2004 ${ }^{1}$ (Chapter 4) with the following doses: 3980, 5010, 6340 and $7940 \mathrm{mg} / \mathrm{kg}$. Each dose in acute experiments was tested on 6 animals (males) at intragastric introduction via a needle probe with the following observation during 14 days. Experiments were performed on sexually mature white rats with body weight being equal to 190-220 grams. We considered intoxication symptoms, animals' behavior and death. Clinical picture of acute intoxication during the first few hours after introduction included heavy breathing, inhibited movements, and insignificant tremor; the symptoms became worse during the first day and later were accompanied with shaky gait, palpebral fissure narrowing, convulsive breathing, refusal to eat, and lateral position. Animals died from respiratory center stop on 1-2 day after the introduction. Rinkor, WG DL50 (lethal dose) calculated as per V.B.

\footnotetext{
${ }^{1}$ Instruction No. 1.1.11-12-35-2004. Requirements for experimental research aimed at primary toxicological assessment and hygienic regulation of substances. Approved by the Public Healthcare Ministry in Republic of Belarus dated December 14, 2004. 42 p. Available at: http://www.vniiki.ru/document/4689864.aspx (16.05.2017).
} 
Prosorovskiy technique [10] amounts to $5210(4400 \div 6100) \mathrm{mg} / \mathrm{kg}$; Graminis, CE DL50, $5620(4300 \div 7400) \mathrm{mg} / \mathrm{kg}$. So, preparatory forms of these two herbicides should be considered low-hazard chemicals as per their acute intragastric toxicity (IV danger category as per State Standard 12.1.007-76 ${ }^{2}$ ).

Examination of acute toxicity at cutaneous application. The experiment was performed in conformity Application Instruction No. $048-1215^{3}$ on white sexually mature rates (males and females, $n=6$ ), with body weight equal to 190-210 grams. Herbicides preparatory forms were once applied on skin areas, $4 \times 4 \mathrm{~cm}$ each, in the middle one-third of a dorsal body surface where fur was cut off; the areas were then covered with gauge bandage and fixed by adhesive plaster. Animals were put into individual cages. Exposure on skin lasted on 24 hours; after that skin was washed with distilled water. We applied the following dose of Rinkor, WG: 1500 (experiment 1), 2000 (experiment 2), 2500 (experiment 3) mg/kg; Graminis, CE: 2000 (experiment 1), 2500 (experiment 2), 5000 (experiment 3) $\mathrm{mg} / \mathrm{kg}$. There were 6 animals in each group. We observed them for 14 days and considered intoxication symptoms nature, body weight dynamics, and animals behavior. Clinical picture of acute intoxication during the first hours after application included insignificant decrease in locomotor activity; animals behavior didn't have any discrepancies from the control group on the next day and during the whole observation period. No animals died during the whole 14-day observation period. Therefore, herbicides preparatory forms should be considered low-hazard chemicals as per their acute cutaneous toxicity parameters (IV danger category as per State Standards 12.1.007-76 $6^{2}$.

Examination of acute toxicity under inhalation exposure. This experiment was performed on sexually mature white rats with body weight equal to 190-200 grams in conformity with the Application Instruction No.047-1215 $5^{4}$ Preparatory forms of herbicides were applied in concentrations equal to $0.5 ; 1.0 ; 2.5$, and $5 \mathrm{mg} / 1$. Inhalation lasted for 4 hours including balancing period. Each dose in acute experiments was tested on 6 animals, 3 males and 3 females, which were then under observation for 14 days. We considered intoxication symptoms, body weight dynamics and animals' behavior. Animals which received herbicides in maximum concentration under inhalation exposure had lower motor activity, their fur was disheveled, and they also had excretion from their noses which stopped during the first day after the exposure was over. All the tested doses didn't cause any deaths. CL50 (a substance concentration which causes deaths of $50 \%$ animals under two-, four-hour inhalation exposure) amounts to more than $5.000 \mathrm{mg} / \mathrm{l}$ $\left(5000 \mathrm{mg} / \mathrm{m}^{3}\right)$. Therefore preparatory forms of herbicides can be considered moderately dangerous chemicals as per their acute inhalation toxicity (III danger

\footnotetext{
${ }^{2}$ State Standard 12.1.007-76. Labor Safety Standards System (LSSS). Hazard substances. Classification and general safety requirements (with Alterations N 1,2): Interstate standard. Available at: http://docs.cntd.ru/document /5200233 (18.05.2017)

${ }^{3}$ Application Instruction No. 048-1215. Determination of chemicals acute toxicity (chemicals and their mixtures) at cutaneous application. Approved by Deputy to Public Healthcare Minister - Chief Sanitary Inspector of Republic of Belarus on August 30, 2016. Available at: http://rspch.by/Docs/048-1215.pdf (20.05.2017).

${ }^{4}$ Application Instruction No. 047-1215.Determination of chemicals acute toxicity (chemicals and their mixtures) under inhalation exposure. Approved by Deputy to Public Healthcare Minister - Chief Sanitary Inspector of Republic of Belarus on August 30, 2016. Available at: http://rspch.by/Docs/047-1215.pdf (20.05.2017).
} 
category as per State Standard 12.1.007$\left.76^{2}\right)$.

Sensitizing effects. The experiment was performed in conformity with the Instruction 1.1.11-12-35-20041

(chapter

$8)$. Intracutaneous introduction of Rinkor WG preparatory form in a challenging dose equal to $100 \mu \mathrm{l}$ into a hindleg pad (below the aponeurosis) of white mice didn't lead to edematic-proliferative reaction evolvement. We measured a pad width in mm before and 24 hours after percutaneous testing with the use of an engineering micrometer. A reaction appearance was assessed both as per absolute (mm) and relative (scores) parameters. Average parameters of a mouse pad swelling test (allergic test) in animals from the focus group didn't have any discrepancies from those in the relevant control group and didn't exceed $0.1 \mathrm{~mm} \quad\left(\begin{array}{ll}0 & \text { scores })\end{array} \quad(<0.05)\right.$. Intracutaneous introduction of Graminis CE herbicide preparatory form in a challenging dose caused edematic-proliferative reaction evolvement. Average parameters of a mouse pad swelling tests differed from those in the relevant control group and amounted to 0.143-0.198 $\mathrm{mm}$ (1 score) $(<0.05)$. The experiment enabled determining that the examined Rinkor WG herbicides preparatory form didn't cause any induration or inflammation in tissues while Graminis CE herbicide preparatory form did as much as a result of tissues infiltration caused by interaction between an antigen (allergen) with macrophages and Thl-lymphocytes which stimulated cellular immunity. So, Rinkor WG herbicide preparatory form can be considered a substance without any sensitizing effects (4 category, no sensitizing effects); Graminis CE is a substance causing weak sensitizing effects ( 3 category (3B subcategory) weak allergen).

Irritating effects on eyes mucous tunics under a single exposure. The experiment was performed in conformity with the Instruction 1.1.11-12-35-2004 (chapter 5) and the Instruction No. 045-1215 $5^{5}$.

Preparatory forms of herbicides in doses equal to 50-100 $\mu \mathrm{l}$ were introduced into a low conjunctival fornix of rabbits' right eyes; 24 hours later the eyes were washed with distilled water; left eyes were taken as control ones and 1-2 drops of distilled water were introduced into them. The examined substances caused lacrimation, serous excretions, and vessels injection after instillation; all these effects stopped on the 1-2 day after washing with water when the exposure ended. Mucous tunics apparently recovered fully during 1-2 days after instillation. So, in case of a single exposure on mucous tunics Rinkor WG herbicide preparatory form exerts weak irritating effects on mucous tunics with average total scoring showing irritating effects evidence being equal to 1.0 (3 category (3B subcategory) weak irritating effects); Graminis CE exerts moderate irritating effects on mucous tunics with average total scoring showing irritating effects evidence being equal to 3.0 (3 category (3A subcategory) moderate irritating effects).

Examination of local irritating properties on skin under a single exposure. The experiment was performed in conformity with the Instruction 1.1.11-1235-2004 ${ }^{1}$ (chapter 6) and the Instruction No. $049-1215^{6}$. Preparatory forms of herbicides were put on bare skin on backs of non-linear white rats, spots on animals backs were located on the right side, their square was $4 \times 4 \mathrm{~cm}$ (left side was taken as

\footnotetext{
${ }^{5}$ Application Instruction No. 045-1215. Determination of chemicals acute irritating effects (chemicals and their mixtures) on eyes mucous tunics. Approved by Deputy to Public Healthcare Minister - Chief Sanitary Inspector of Republic of Belarus on August 30, 2016. Available at: http://rspch.by/Docs/045-1215.pdf (20.05. 2017).
} 
control); doses were equal to $20 \mathrm{mg} / \mathrm{cm} 2$ and were applied only once with application duration equal to 4 hours. We considered skin state and how apparent skin reactions were. Preparatory forms of herbicides under a single exposure on bare spots located on rats' backs didn't exert any irritating effects scoring 0 (4 category) (absence of irritating effects).

Cumulative properties assessment. The experiment was performed in conformity with the Instruction No. 052-1215 on white male rats with body weight equal to 170-200 grams, aged 8-12 weeks, which we bred ourselves. The total number of experimental animals was 14 (7 male rats in the focus group and 7 in the control one). To assess cumulative properties of herbicides preparatory form, we chose a dose equal to $\approx 1 / 10$ from the maximum dose introduced in an acute experiment. Rinkor WG herbicide dose was equal to $500 \mathrm{mg} / \mathrm{kg}$ of body weight; Graminis CE, $550 \mathrm{mg} / \mathrm{kg}$ of body weight. We didn't detect any animals' deaths during the whole experiment. So, the examined preparatory forms don't have any cumulative properties with lethal effects (cumulation coefficient $>5$ ).

All the detected statistically significant changes in some morphofunctional parameters chosen for assessing toxicological effects exerted by the examined substances after 90-days intragastric re-introduction are most likely to be compensatoryadaptive.

We performed microscopic pathomorphologic examination of internal organs and didn't detect any visible changes. We determined that liver and kidneys were most typical target organs for sulfonylurea (Rinkor WG and Graminis CE herbicides).

We performed hygienic assessment of working conditions at workplaces where herbicides were applied on a test field during a single spraying via a tractor rod sprayer, potatoes tops being $5-25 \mathrm{~cm}$ high, discharge rate being $50 \mathrm{~g} / \mathrm{hectare}$, and working fluid discharge being 250 1/hectare (Rinkor WG), and $50 \mathrm{~g} /$ hectare, 200 1/hectare, correspondingly for Graminis CE. Work lasted for 40 minutes; working shift duration was 6 hours; daily rate of a treated square was 25 hectares.

The experiment allowed to detect that substances contaminated certain spots on workers bodies, both protected with individual protection means (neck and breast) and unprotected (face). In relation to that average dermal load (concentration) for the rest chosen spots was calculated allowing for $1 / 2$ detection limit for samples having "not detected" value and amounted to $0.00125 \mathrm{mg} / \mathrm{m} 2$ for herbicides contaminating bodies of a refilling operator and a sprayer operator. Workers didn't feel themselves bad; they didn't have any skin irritations or eyes mucous tunics irritation; they didn't complain on any health deterioration after work.

We performed hygienic assessment of risks for people contacting the examined substances during potatoes corps treatment with discharge rate being equal to 50 $\mathrm{g} /$ hectare in conformity with the Methodical guidelines No. 2001/73 [7]. Risks of

\footnotetext{
${ }^{6}$ Application Instruction No. 049-1215. Determination of chemicals acute irritating effects on skin (chemicals and their mixtures). Approved by Deputy to Public Healthcare Minister - Chief Sanitary Inspector of Republic of Belarus on August 30, 2016. Available at: http://rspch.by/Docs/2 049.pdf (20.05. 2017)

${ }^{7}$ Application Instruction No. 052-1215. Determination of chemicals toxicity (chemicals and their mixtures) and repeat and chronic intragastric introduction. Approved by Deputy to Public Healthcare Minister - Chief Sanitary Inspector of Republic of Belarus on August 30, 2016. Available at: http://rspch.by/Docs/052-1215.pdf (20.05.2017)
} 
adverse effects caused by the substances exposure on skin were determined via comparison between actual skin exposure (Eac, $\mathrm{mg} / \mathrm{cm} 2$ ), calculated on the basis of the obtained data and tentatively permissible level of skin contamination (TPLs.c., $\mathrm{mg} / \mathrm{cm} 2$ ) (Table).

Total risks for a refilling operator and a sprayer operator under cutaneous and inhalation exposure to herbicides during potatoes crops treatment

\begin{tabular}{|l|c|c|c|c|}
\hline \multirow{2}{*}{ Calculated coefficients } & \multicolumn{4}{|c|}{ The substance } \\
\cline { 2 - 5 } & \multicolumn{2}{|c|}{ rimsulfuron (Rinkor WG) } & \multicolumn{2}{|c|}{$\begin{array}{c}\text { chisalofop-p-ethyl } \\
\text { (Graminis CE) }\end{array}$} \\
\cline { 2 - 5 } & $\begin{array}{c}\text { A sprayer } \\
\text { operator }\end{array}$ & $\begin{array}{c}\text { Refilling op- } \\
\text { erator }\end{array}$ & $\begin{array}{c}\text { A sprayer op- } \\
\text { erator }\end{array}$ & $\begin{array}{c}\text { Refilling op- } \\
\text { erator }\end{array}$ \\
\hline $\begin{array}{l}\text { Safety coefficient under cutaneous pesticide } \\
\text { introduction dermal exposure risk), } \mathrm{SC}_{\mathrm{d} .}\end{array}$ & 0,018000 & 0,028000 & 0,029 & 0,029 \\
\hline $\begin{array}{l}\text { Safety coefficient under inhalation introduc- } \\
\text { tion (inhalation exposure risk), } \mathrm{SC}_{\text {inh. }}\end{array}$ & 0,003333 & 0,000333 & 0,075 & 0,075 \\
\hline Total risk, $\mathrm{SC}_{\text {total. }}$ & 0,021333 & 0,028333 & 0,104 & 0,104 \\
\hline Standard total risk value, $\mathrm{SC}_{\text {total. }}$ & $<1$ & $<1$ & $<1$ & $<1$ \\
\hline
\end{tabular}

Notes: $\mathrm{E}_{\mathrm{ac}}$ is actual skin exposure, $\mathrm{mg} / \mathrm{cm}^{2} ; \mathrm{MPC} / \mathrm{TSEL}_{\text {w.a.a. }}$ is maximum permissible concentration/tentatively safe exposure level in work area air

\section{Conclusions:}

1. Preparatory forms of herbicides should be considered low-hazard chemicals as per their acute intragastric toxicity (IV danger category as per State Standard 12.1.007-76).

2. Preparatory forms of herbicides should be considered low-hazard chemicals as per their acute cutaneous toxicity (IV danger category as per State Standard 12.1.007-76).

3. Preparatory forms of herbicides should be considered moderately hazardous chemicals as per their acute inhalation toxicity (III danger category as per State Standard 12.1.007-76).

4. Pinkor WG herbicide preparatory form can be considered a substance without any sensitizing effects (4 category, absence of sensitizing effects); Graminis CE, a substance with weak sensitizing effects ( 3 category (3B subcategory), weak allergen).

5. Herbicide Rinkor WG preparatory form under a single exposure on mucous tunics exerts weak irritating effects on them with total scoring showing irritating effect evidence being equal to 1.0 ( 3 category (3B subcategory), weak irritating effects); Graminis CE exerts moderate irritating effects on mucous tunics with total scoring showing irritating effect evidence being equal to 3.0 (3 category ( $3 \mathrm{~A}$ subcategory), moderate irritating effects).

6. Herbicides preparatory forms don't exert any irritating effects on skin as there were no such effects on bare skin spots located on white rats' backs; scoring is 0 (4 category), absence of irritating effects).

7. The examined preparatory forms don't have any cumulative properties with lethal effects (cumulation coefficient is $>5$ ).

8 . We didn't detect any changes in internal organs via microscopic pathomorphologic examination.

9. Calculated risks of complex (inhalation and dermal) effects exerted by Graminis $\mathrm{CE}$ and Rinkor WG herbicides on workers (a refilling operator and a sprayer operator) during their application in agriculture don't exceed permissible levels (are less than 1). 


\section{References}

1. Vasil'ev D.S. Primenenie gerbitsidov, desikantov i defoliantov na posevakh maslichnykh kul'tur [Application of herbicides, dessicants, and defoliants on oil-plant crops]. Maslichnye kul'tury: Nauchnotekhnicheskii byulleten' Vserossiiskogo nauchno-issledovatel'skogo instituta maslichnykh kul'tur, 1967, pp. 83-85 (in Russian).

2. Vasil'ev D.S. Rekomendatsii po bor'be $s$ ambroziei polynnolistnoi [Recommendations on fighting against ragweed]. Krasnodar, 1970, 21 p. (in Russian).

3. Gerbitsidy [Herbicides]. KhiMik: sait o khimii. Available at: http://www.xumuk.ru/encyklopedia/983.html (02.04.2017) (in Russian).

4. Goncharov N.R., Kashirskii O.P. Velichina urozhaya, sokhranyaemogo blagodarya primeneniyu pestitsidov [Size of a crop which is preserved due to herbicides application]. Zashchita $i$ karantin rastenii, 2004, no. 10, pp. 49 (in Russian).

5. Izhevskii S.S. Negativnye posledstviya primeneniya pestitsidov [Negative consequences of herbicides application]. Zashchita $i$ karantin rastenii, 2001, no. 5, pp. 16-19 (in Russian).

6. Mel'nikov H.H. Pestitsidy. Khimiya, tekhnologiya i primenenie [Pesticides. Chemistry, technology, and application]. Moscow, 1987, 712 p. (in Russian).

7. Metod otsenki riska vozdeistviya pestitsidov na rabotayushchikh: Metodicheskie rekomendatsii №2001/73 [A technique for assessing risks caused by exposure to herbicides on workers: Methodical guidelines No.2001/73]. Moscow, 2001, 18 p. (in Russian).

8. Metodicheskie ukazaniya po gigienicheskoi otsenke novykh pestitsidov / utv. MZ SSSR 13.03.87 № 4263-87 [Methodical guidelines on hygienic assessment of new pesticides / approved by the USSR Public Healthcare Ministry on March 13, 1987 No. 4263-87]. Kiev, Minzdrav SSSR, Publ., 1988, 210 p. (in Russian).

9. Milovanova Z.G. Chem propalyvat' podsolnechnik [How to weed a sunflower]. Zashchita $i$ karantin rastenii, 2005, no. 3, pp. 44 (in Russian).

10. Prozorovskii V.B., Prozorovskaya V.M., Demchenko V.M. Ekspress-metod opredeleniya srednei effektivnosti dozy i ee oshibki [Rapid test method to determine average dose efficiency and its error]. Farmakologiya i toksikologiya, 1978, no. 4, pp. 497-502 (in Russian).

11. Greene S.A. Sittig's Handbook of Pesticides and Agricultural Chemicals. USA SciTech Publishing, Inc, 2006, $1213 \mathrm{p}$.

12. Hamilton D., Crossley S. Pesticide residues in food and drinking water. J. Wiley, 2004, pp. 22.

13. Kegley S.E., Wise L.J. Pesticides in fruits and vegetables: University Science Books. Great Britain, $1998,78 \mathrm{p}$.

14. Levine M.J. Pesticides: A Toxic Time Bomb in our Midst. Praeger Publishers, 2007, 265 p.

15. Hond F. [et al.]. Pesticides: problems, improvements, alternatives. Blackwell Science. Great Britain, $2003,273 \mathrm{p}$. $1350 \mathrm{p}$

16. Tomlin C. The Pesticide Manual, $14^{\text {th }}$ edn. London: British Crop Protection Council (BCPC), 2006,

17. Ware G.W., Whitacre D.M. Pesticide Book. Great Britain: Meister Publishing Co, 2004, 488 p.

Vasileva M.M., Popel A.A., Yurkevich E.S., Ilyukova I.I. Hygienic assessment of risk caused by application of Graminis KE and Rinkor VG herbicides. Health Risk Analysis, 2017, no. 4, pp. 49-56. DOI: 10.21668/health.risk/2017.4.05.eng

Received: 26.06.2017

Accepted: 11.12.2017

Published: 30.12 .2017 
UDC 618.14-002-036.12-07

DOI: $10.21668 /$ health.risk/2017.4.06.eng

\section{HIGH RISKS OF SOMATIC PATHOLOGY IN WOMEN WITH CHRONIC ENDOMETRITIS}

\section{E.G. Kobaidze, M.M. Padrul}

Perm State Medical University named after Academician E. A. Wagner, 26 Petropavlovskaya Str., Perm, 614000, Russian Federation

As women fertility is obviously decreasing at present, a number of people who, being at the reproductive age, suffer from various diseases is only growing and it is truly a vital issue. Chronic endometritis which is a problem in contemporary gynecology and reproductive performance studies may cause menstrual function disorders, anemia, and chronic pelvis pains syndrome. Our research goal was to assess risks of somatic pathology evolvement and life quality of women suffering from chronic endometritis. The focus group was made up of 42 patients at their fertile age who suffered from chronic endometritis $(n=42) ;$ the reference group consisted of practically healthy females at the same age $(n=33)$ who applied to a gynecologist in order to make a choice on a contraceptive.

We detected that women with chronic endometritis had somatic pathologies much more frequently that women from the reference group; such pathologies included chronic gastritis, functional disorders in the bowels, gall-bladder diseases, urinary system diseases, and chronic rhinopharyngitis (relative risks varied from 1.25 to 4.62; $p<0.05)$. High somatic pathology parameters indicate there is a decrease in immunologic protection and non-specific reactivity to pathologic changes in molecular mechanisms involving tissue and cellular homeostasis disorders. Patients form the focus group had lower life quality, weaker endurance and greater fatigue, lower emotional and social activity.

When doctors of all specialities treat patients with chronic endometritis they are advised to apply healthrestoring treatment at any stage when a patient applies for medical assistance (and not only when she is getting ready for a pregnancy). We highlight the necessity to create individual sets of pharmaceuticals, physiotherapy and balneal techniques, and diet therapy for basic metabolic processes recovery, antioxidant processes recovery, immunologic protection and non-specific reactivity improvement. It is also necessary to treat not only gynecological pathology, but also a concomitant somatic one.

Key words: reproductive age, chronic inflammatory pathology, somatic diseases, life quality, chronic endometritis, reproductive health.

The World Health Organization sticks to the following reproductive health definition: "Reproductive health is a state of complete physical, mental, and social wellbeing; it does not mean simple absence of any diseases related to the reproductive system, its functions, and processes". As female fertility is going down nowadays, more and more people of reproductive age turn out to have various diseases, both of somatic and gynecological genesis, which can cause infertility, and it remains a very serious issue. A number of auxiliary reproductive technologies aimed at treating infertility has grown over the last years. However, there are certain pathologies which are too difficult to treat and which cause unsuccessful embeddings in case when auxiliary reproductive technologies are applied. Particularly, nowadays the

(C) Kobaidze E.G., Padrul M.M., 2017

Ekaterina G. Kobaidze - Candidate of Medical Science, Associate Professor of the Department of Obstetrics and Gynecology (e-mail: eka7i@yahoo.com; tel.: +7 (342) 236-39-30).

Mikhayl M. Padrul - Doctor of Medical Science, Professor, Head of the Department of Obstetrics and Gynecology (e-mail: m-padrul@mail.ru; tel.: +7 (342) 236-39-30). 
uterine factor is becoming a complicated and poorly treatable infertility issue all over the world. Epidemiological parameters of chronic endometritis in women of fertile age are quite different, from $1 \%$ to $70 \%$; but its contribution into reproduction disorders is not under any discussion $[9,12]$. This pathology outcomes are individual in each case, as it is hardly possible to predict endometrial functional state in these patients in spite of great number of contemporary laboratory-diagnostic techniques for examining uterus mucous tunic state. Chronic endometritis can become a serious problem for a patient: it causes menstrual disorders in women, anemia, chronic pelvis pain syndrome, chronic fatigue, infertility, and it lowers overall life quality. We should also note that oncologic gynecological pathologies increase in patients with chronic diseases in their case history and it accordingly proves it is necessary to get better insights into the issue $[10,14]$. Inflammation process under chronic endometritis progresses wavelike, specific clinic symptoms are absent, etiological agents in endometrium are hard to identify, physiological factors of protection from damage fail, disorders in endometrium receptivity evolve, a doctor and a patient tend to underestimate clinical signs, the disease can possibly have autoimmune character, and so, etiotoropic therapy issue arises; all the above-said characterizes chronic endometritis nowadays.

When endometritis occurs, acute or chronic inflammation evolves and a whole body is involved in it to a certain extent. Endogenous protection systems and search for universal regulators of physiological body functions attract doctors' closest attention when it comes to complications prevention and rehabilitation. When pathogenic factors exert their impacts on a body, basic inflammatory and immune response schemes start to work: inflammation occurs, antigen-representing cells start to function, an adaptive immune response evolves, immune lymphocytes-effectors migrate, antibodies concentrations in inflammation focus grow, antigens and tissues damaged by pathogens are destroyed, and decay products are discharged from a body by its excretory systems, namely the liver, kidneys, bowels, etc. [2, 7, 15]. Chronic inflammation pathologies occurrence in the gastrointestinal tract or urinary tracts are now considered by practicing gynecologists as related to chronic endometritis. Extragenital chronic inflammation focuses can contribute into a decrease in a body adaptive abilities and make for chronic inflammation pathologies in the uterus. There are opinions that any chronic infection focus in a body, including chronic adnexitis, can be a source of infection which penetrates the gall bladder [3], thus causing chronic non-calculous cholecystitis. We should note that possible reserve impacts exerted by inflammations in the gall bladder on endometrium state are not studied enough. There are some data in literature on pathologic impacts exerted by chronic tonsillitis on menstrual function development in girls and on pregnancy complications [6]. There are also some data on microflora persisting in endometrium of patients suffering from chronic endometritis being similar to that occurring in the palatine tonsils [11]. Negative influence which chronic pyelonephritis has on pregnancy course is beyond any questions now $[4,5$, 13]. But its occurrence in gynecological patients is not well examined. And as a number of healthy women is decreasing now, it is undoubtedly vital to assess their life quality. Therapeutic approach improvement is not possible without imple- 
mentation of recommendations obtained on the basis of such research.

Our research goal was to assess life quality and risks for somatic pathology occurrence in women suffering from chronic endometritis.

Data and methods. We performed our research in a form of clinical analytical prospective analysis. We examined 75 women of reproductive age permanently living in Perm (in 2015 and 2017). The examined women were divided into 2 groups: the first one was made of practically healthy women $(n=33)$, who applied to a doctor in order to make a choice on a contraceptive; the second groups was made of patients $(n=42)$ suffering from chronic endometritis. We used the following criteria to select and include women into our sampling:

- chronic endometritis was diagnosed and the diagnosis was verified by morphologic examinations;

- the disease was diagnosed more than 1 year ago;

- there was no acute somatic pathology or an exacerbation of the chronic one;

- absence of any signs proving there was exacerbation of chronic inflammatory pathology in small pelvis organs (chronic salpiginitis, oophoritis, endometritis, cervicitis, vaginitis).

Complex examinations performed on patients included passport data analysis, case history analysis, menstrual and reproductive functions assessment, general clinical and gynecological research, somatic pathologies detection, general clinical laboratory tests, life quality assessment via SF-36, and statistical analysis techniques.

SF-36 questionnaire is a non-specific one aimed at life quality (LQ) assessment. It is widely used in conducting research on life quality of healthy population and groups of patients with various chronic dis- eases. Life quality was analyzed as per several scales $[1,8,16,17]$ :

1. Physical Functioning or PF. This scale shows to what extent physical state limits physical loads; low scoring means a respondent's physical activity is significantly limited by his or her health.

2. Role-Physical Functioning or RP. This scale determines how physical state of a person influences his or her everyday life; low scoring means that a person faces certain limitations in his or her everyday life caused by his or her health state.

3. Bodily pain or BP. This scale allows to find out how intense a pain syndrome is and how it influences an examined person's ability to pursue his or her everyday activities; low scoring also means that everyday activities are seriously limited because of pain.

4. General Health or GH. This scale shows how a woman assesses her health and her resistance to diseases; low scoring proves there is health deterioration.

5. Vitality or VT. The scale is based on subjective feelings of a respondent and allows to assess whether he or she suffers from excessive fatigue or on the contrary is full of energy; low scoring means fatigue is excessive.

6. Social Functioning or SF. This scale allows to assess satisfaction with social activity level; accordingly, low scoring proves social activities are also low.

7. Role-Emotional or RE. The scale shows how emotional state influences a patient's everyday activities; low scoring means that working capacity is reduced due to poorer emotional state.

8. Mental Health or MH. The scale allows to assess patients' moods; low scoring proves a patient has increased anxiety.

Parameters on each scale vary from 0 to 100 scores, where 100 means absolute health. The higher scoring is, the higher 
life quality is and the better health is; the results are given in scores as per 8 scales made up in such a way that a higher scoring means a better life quality $[16,17]$. Parameters as per 2 groups were assessed and represented by the median (Me) and a percentile interval 25-75. We applied distribution-free techniques (Mann-Whitney test for comparing two independent samplings) to compare both groups and examine possible correlations. To analyze dependences between a frequency of a parameter occurrence (somatic and gynecologic pathology) in a group, we applied chi-square criterion $(\chi 2)$. We analyzed discrepancies between groups as per parameters occurrence frequencies also with $\chi 2$ criterion. We calculated odds relation (OR) with 95\%confidence interval and applied relative risk with $95 \%$-confidence interval as a way to assess risk factors and possibility of health disorders in female patients.

Results and discussion. Women from the first group were from 19 to 44 (average age was $30.90 \pm 7.09$ ); from the second, from 21 to 44 (average age was $34.11 \pm 4.79)$. Reproductive case history analysis in the first group revealed the following peculiarities: 11 women had childbirth in their case history $(33.33 \pm 16.72 \%)$; 5 miscarriages which happened during first 5 gestation weeks were detected in $15.15 \pm 12.71 \%$ women, $\chi^{2}=3.46 ; p=0.06$; we didn't detect any frozen pregnancies in this group; medical abortions were made in $24.24 \pm 15.2 \%$ (8) cases, $\chi^{2}=6.97 ; p=0.008$, that is, frequency of this parameter occurrence in this group was statistically significant; $96.97 \pm 6.08 \%$ women practiced birth control and used condoms to protect themselves from unwanted pregnancies, and it proved that frequency of this parameter occurrence was statistically significant for this category of the examined women $\left(\chi^{2}=58.30 ; \mathrm{p}<0.001\right)$.
Our analysis of gynecological case history which patients from the 1 st group had revealed that $6.06 \pm 8.46 \%$ women suffered from such proliferative uterus diseases as leiomyoma, and we didn't detect adenomyosis in this group. We analyzed frequency of chronic reproductive system inflammations occurrence and revealed that women didn't have chronic salpiginitis, adnexitis, or cervicitis; chronic cervicitis led to surgery on the uterine neck in 2 patients $\left(6.06 \pm 8.46 \%, \chi^{2}=0.52 ; p=0.473\right)$. Menstrual cycle characteristics revealed that menarche occurred timely in $87.88 \pm 11.57 \%$ (29) women and we didn't detect any other menstrual disorders in this group.

Reproductive case history analysis performed on women suffering from chronic endometritis revealed the following: $57.14 \pm 15.42 \%$ (24) patients had primary and secondary infertility, $\chi^{2}=30.86$; $\mathrm{p}<0.001 ; 14$ patients $(33.33 \pm 14.69 \%)$ had childbirth, $54.76 \pm 15.51 \%$ women had medical abortions $(p<0.001)$, and it indicated that frequency of this parameter occurrence in this patients' group was statistically significant. Pregnancy had an unfavorable outcome, namely miscarriage or frozen pregnancy, in $26.19 \pm 13.7 \%$ $\left(\chi^{2}=10.46 ; p<0.001\right)$ cases and it indicated that frequency of this parameter occurrence among these patients was also statistically significant. $14.29 \pm 10.9 \%$ (6) women suffered from proliferative uterus diseases (leiomyoma) and frequency of this parameters occurrence was also statistically significant, $\chi^{2}=4.49 ; \mathrm{p}=0.034$. Adenomyosis was detected in $9.52 \pm 9.15 \% \quad(4), \quad \chi^{2}=2.36$; $\mathrm{p}=0.124$, that is, the parameter was not statistically significant in this group. Our analysis of chronic reproductive system inflammations revealed that $40.48 \pm 15.3 \%$, $\left(\chi^{2}=18.88 ; \mathrm{p}<0.001\right)$ suffered from chronic salpiginitis and adnexitis; 47.62 $\pm 15.56 \%$ $(\mathrm{p}<0.001)$, from chronic cervicitis; 
$52.38 \pm 15.56 \%(\mathrm{p}<0.001)$ patients had surgery on the uterine neck in their case history. Women suffering from chronic endometritis had various menstrual function disorders in $\quad 69.05 \pm 14.41 \%$ cases $\left(\chi^{2}=10.46 ; \quad \mathrm{p}<0.001\right), \quad$ algomenorrhea
$(28.57 \pm 14.08 \% ; \quad p<0.001)$ and profuse menses $(19.05 \pm 12.24 \%$ patients; $p<0.001)$ were statistically significant. Comparative characteristics of all the above mentioned parameters is given in Table 1 .

Table 1

Comparative characteristics of the obstetric-gynecological case history between two groups

\begin{tabular}{|l|c|c|c|c|c|c|}
\hline \multicolumn{1}{|c|}{ Signs } & $\begin{array}{c}\text { Groups } \\
(\mathrm{n}=33) \%\end{array}$ & $\begin{array}{c}\text { Groups 2 } \\
(\mathrm{n}=42) \%\end{array}$ & $\mathrm{Chi}^{2}$ & $\mathrm{R}$ & OR & CI 95\% \\
\hline Child birth & $33,33 \pm 16,0$ & $33,33 \pm 14,6$ & 0,061 & 0,805 & 1,000 & 0,$38 ; 2,63$ \\
\hline Infertility & 0 & $57,14 \pm 15,4$ & 15,584 & $0,001^{*}$ & 416,00 & $25 ; 4195,12$ \\
\hline Medical abortion & $24,24 \pm 15,0$ & $54,76 \pm 15,5$ & 5,896 & $0,015^{*}$ & 3,783 & 1,$39 ; 10$ \\
\hline Miscarriage & $15,15 \pm 12,0$ & $26,19 \pm 13,7$ & 0,765 & 0,382 & 1,987 & 0,$61 ; 6,43$ \\
\hline Frozen pregnancy & 0 & $26,19 \pm 13,7$ & 4,252 & $0,039^{*}$ & - & - \\
\hline Menstrual dysfunctions & 0 & $69,05 \pm 14,4$ & 22,517 & $0,001^{*}$ & - & - \\
\hline Leiomyoma & $6,06 \pm 8,4$ & $14,29 \pm 10,9$ & 0,591 & 0,442 & - & - \\
\hline Adenomyosis & 0 & $9,52 \pm 9,2$ & 0,799 & 0,371 & - & - \\
\hline Chronic salpiginitis & 0 & $40,48 \pm 15,3$ & 8,527 & $0,003^{*}$ & - & - \\
\hline Chronic adnexitis & 0 & $40,48 \pm 15,3$ & 8,527 & $0,003^{*}$ & - & - \\
\hline Chronic cervicitis & 0 & $47,62 \pm 15,5$ & 11,234 & $0,001^{*}$ & - & - \\
\hline Surgery on the uterine neck & $6,06 \pm 8,4$ & $52,38 \pm 15,5$ & 16,155 & $0,001^{*}$ & 17,050 & 3,$61 ; 80,56$ \\
\hline Contraception & $96,97 \pm 6,08$ & $61,9 \pm 15,1$ & 7,716 & $0,005^{*}$ & 0,000 & - \\
\hline
\end{tabular}

Note:* - means that statistically significant discrepancies in a parameter occurrence frequency were detected between healthy women and those suffering from chronic endometritis

When we compared analyzed parameters in healthy women and in female patients with chronic endometritis we revealed that there were statistically significant discrepancies in occurrence frequency of medical abortion (made to get rid of $\chi$ unwanted pregnancy, the parameter was higher in patients with chronic endometritis), chronic adnexitis and salpiginitis, chronic cervicitis, frozen pregnancy, and infertility.

As per body mass index, healthy women from group I were divided into the following sub-groups: $23(69.7 \pm 16.3 \%)$ out of 33 women had normal parameters (18.50-24.99); 10 (30.3 $\pm 16.3 \%)$ women had excessive body weight and 1st degree obesity $\left(\chi^{2}=9.55 ; p=0.002\right)$. A share of women with normal body mass in group 2 amounted to $69.05 \pm 14.41 \%$

(29);
$30.95 \pm 14.41 \%$ (13) had lipid metabolism disorders; $\chi^{2}=13.11 ; p<0.001$.

We analyzed gastrointestinal tract disorders in the examined women and revealed that 4 women $(12.5 \pm 11.92 \%$, $\left.\chi^{2}=2.40 ; p=0.121\right)$ in the first group $(n=33)$ suffered from chronic gastritis, and 3 $\left(9.09 \pm 10.19 \%, \quad \chi^{2}=1.40 ; \quad p=0.237\right) \quad$ had chronic pancreatitis; functional bowels disorders (notably, irritable bowels syndrome) were detected in 1 patient $(3.03 \pm 6.08 \%)$, gall bladder disorders (including gall bladder dyskinesia and biliary tracts dyskinesia) were also detected in only 1 patient $(3.03 \pm 6.08 \%)$. We didn't detect any urinary system disorders (chronic pyelonephritis, cystitis, or urethritis), or thyroid gland disorders (hypothyroidism or hyperthyroidism) in women from the first group. We detected 2 cases $\left(6.06 \pm 8.46 \%, \chi^{2}=0.52\right.$; 
$\mathrm{p}=0.473$ ) of chronic respiratory tracts disorders (chronic pharyngitis, rhinitis, or rhinopharyngitis). More than half of them had food allergy or household chemicals allergy, $6\left(18.18 \pm 13.68 \%, \chi^{2}=4.52 ; p=0.003\right)$ women had broad spectrum antibiotics allergy.

Gastrointestinal tract diseases analysis in the 2nd group $(n=42)$ revealed that $57.14 \pm 15.42 \%$ had chronic gastritis, and $42.86 \pm 15.42 \%$ were healthy, $\chi^{2}=30.86$; $\mathrm{p}<0.001$; chronic pancreatitis was detected in $23.81 \pm 13.27 \%$ (10 women), $\chi^{2}=9,19$; $\mathrm{p}=0.002$; bowels functional disorders, in $64.29 \pm 14.93 \% \quad$ (27 patients), $\quad \chi^{2}=36.90$; $\mathrm{p}<0.001$; gall bladder disorders were detected in $61.9 \pm 15.13 \%$ (26) cases, $\chi^{2}=34.81 ; \quad \mathrm{p}<0.001 . \quad 21 \quad$ patients $(50 \pm 15.58 \%)$, had urinary system diseases $\chi^{2}=25.40 ; p<0.001$. Thyroid gland diseases were detected in $5(11.9 \pm 10.09 \%)$ women; chronic respiratory tract diseases, in particular, chronic rhinitis, in $19.05 \pm 12.24 \%$ patients, $\chi^{2}=6.77 ; p=0.009$, and chronic rhinopharyngitis, in $28.57 \pm 14.08 \%, \chi^{2}=11.76$, $\mathrm{p}<0.001 .15$ patients $\left(35.71 \pm 14.93 \%, \chi^{2}=\right.$ $15.91 ; \mathrm{p}<0.001)$ had broad spectrum antibiotics allergy.
We applied Mann-Whitney criterion and revealed statistically significant discrepancies between 2 groups as per blood analysis. Notably, women from the groups 2 (patients with chronic endometritis) had greater quantities of stab neutrophils, lymphocytes, and monocytes, as well as low erythrocytes sedimentation rates, which could possibly indicate their immune protection was weaker, and their non-specific body reactivity, lower (Table 2).

Comparison between patients from the 1 st and 2nd group allowed to reveal statistically significant discrepancies between occurrence frequency of such diseases as chronic gastritis, bowels functional disorders, gall bladder diseases, urinary system diseases, and chronic rhinopharyngitis. the above-mentioned pathologies occurred more frequently in patients suffering from chronic endometritis. We also detected statistically insignificant discrepancies between occurrence frequency of such parameters as body mass index deviations, chronic pancreatitis, chronic rhinitis, antibiotics allergy in groups of healthy and sick women. Comparative characteristics of the above-mentioned pathologies is given in Table 3.

Table 2

Comparative characteristics as per blood analysis between 2 groups

\begin{tabular}{|l|c|c|c|}
\hline \multicolumn{1}{|c|}{ Blood analysis parameters } & $\begin{array}{c}\text { group1 } \\
(\mathrm{n}=33) \\
\mathrm{Me} \\
(25 \%-75 \%)\end{array}$ & $\begin{array}{c}\text { group 2 } \\
(\mathrm{n}=42) \\
\mathrm{Me} \\
(25 \%-75 \%)\end{array}$ & p-level \\
\hline Leucocytes $\left(10^{*} 9\right)$ & $5,2(4,7-5,5)$ & $4,7(4,1-5,3)$ & $0,029^{*}$ \\
\hline Stab neutrophils (\%) & $2(1-2)$ & $2(2-3)$ & $0,005^{*}$ \\
\hline Monocytes (\%) & $9(6-10)$ & $11(9-12)$ & $0,003^{*}$ \\
\hline Lymphocytes (\%) & $31(27-35)$ & $36(33-40)$ & $0,001^{*}$ \\
\hline Thrombocytes $\left(10^{*}\right)$ & $244(226-286)$ & $221(211-267)$ & $0,024^{*}$ \\
\hline Erythrocytes sedimentation rate $(\mathrm{mm} / \mathrm{h})$ & $13(11-15)$ & $7(5-12)$ & $0,001^{*}$ \\
\hline Hemoglobin $\mathrm{g} / 1$ & $127(124-132)$ & $124(114-134)$ & 0,246 \\
\hline
\end{tabular}

Note:* - means Mann-Whitney criterion allowed to reveal statistically significant discrepancies between 2 groups. 
Table 3

Comparative characteristics of somatic pathologies between groups

\begin{tabular}{|l|c|c|c|c|c|c|}
\hline \multicolumn{1}{|c|}{ Parameter } & $\begin{array}{c}\text { Group } \\
1(\mathrm{n}=33) \\
\%\end{array}$ & $\begin{array}{c}\text { Group 2 } \\
(\mathrm{n}=42) \\
\%\end{array}$ & $\mathrm{Chi}^{2}$ & $\mathrm{P}$ & OR & CI 95\% \\
\hline BMI & $30,3 \pm 16,3$ & $30,95 \pm 14,4$ & 0,04 & 0,848 & 1,031 & 0,$38 ; 2,77$ \\
\hline Chronic gastritis & $12,5 \pm 11,9$ & $57,14 \pm 15,4$ & 13,6 & $0,001^{*}$ & 9,333 & 2,$78 ; 31,39$ \\
\hline Chronic pancreatitis & $9,09 \pm 1,01$ & $23,81 \pm 13,2$ & 1,9 & 0,172 & 3,125 & 0,$78 ; 12,46$ \\
\hline Bowels functional disorders & $3,03 \pm 6,0$ & $64,29 \pm 14,9$ & 27,1 & $0,001^{*}$ & 57,60 & 7,$14 ; 464,79$ \\
\hline Gall bladder diseases & $3,03 \pm 6,0$ & $61,9 \pm 15,1$ & 25,3 & $0,001^{*}$ & 52,00 & 6,$46 ; 418,55$ \\
\hline Urinary system diseases & 0 & $50,0 \pm 15,5$ & 12,2 & $0,001^{*}$ & - & - \\
\hline Thyroid gland diseases & 0 & $11,9 \pm 10,0$ & 1,1 & 0,300 & - & - \\
\hline Chronic rhinitis & $6,06 \pm 8,4$ & $19,05 \pm 12,2$ & 1,4 & 0,229 & 3,412 & 0,$67 ; 17,36$ \\
\hline Chronic rhinopharyngitis & $6,06 \pm 8,4$ & $28,27 \pm 14,0$ & 4,8 & $0,029 *$ & 6,200 & 1,$28 ; 30,07$ \\
\hline Antibiotics allergy & $18,18 \pm 13,0$ & $35,71 \pm 14,9$ & 2,015 & 0,156 & 2,500 & 0,$84 ; 7,41$ \\
\hline
\end{tabular}

Note: * - means that statistically significant discrepancies in a parameter occurrence frequency were detected between healthy women and those suffering from chronic endometritis.

When we calculated relative health disorders risk in terms of a significant somatic pathology in patients suffering from chronic endometritis, we obtained the following results: chronic gastritis risk (RR) was equal to 2.190 , OR $95 \% 1.48 ; 3.24$; bowels functional disorders (RR), 3.021, OR 95\% 1.98;4.62; gall bladder diseases (RR), 2.889, OR 95\% 1.92;4.34; urinary system diseases (RR), 2.571, OR 95\% 1.84;3.59; chronic rhinopharyngitis (RR) 1.743, OR 95\% 1.25;2.43 (correlation was thought to be significant at $\mathrm{p}<0.05)$, and it indicated that women from the 2nd group ran higher risks of somatic pathologies oc- currence. Bearing our research goals in mind, we analyzed women's questionnaires as per life quality and revealed statistically significant discrepancies between two groups as per two scales. We should highlight that patients suffering from chronic endometritis had lower Role-Emotional functioning capacities, greater anxiety, mental ill-being, lower health self-esteem and lower resistance to diseases, they assessed their treatment prospects skeptically, and all this undoubtedly meant life quality of these women was rather poor (comparison results are given in Table 4).

Table 4

Comparative characteristics of life quality between 2 groups

\begin{tabular}{|l|c|c|c|}
\hline \multicolumn{1}{|c|}{ Parameters } & $\begin{array}{c}\text { Group 1 (n=33) Me } \\
(25 \%-75 \%)\end{array}$ & $\begin{array}{c}\text { Group 2 (n=42) Me } \\
(25 \%-75 \%)\end{array}$ & p-level \\
\hline Physical functioning & $65(59-68)$ & $44(42-54)$ & $<0,001^{*}$ \\
\hline Role physical functioning & $68(67-71)$ & $47(44-49)$ & $<0,001^{*}$ \\
\hline Bodily pain & $71(69-74)$ & $43,5(38-47)$ & $<0,001^{*}$ \\
\hline Vitality & $71(70-73)$ & $48(45-51)$ & $<0,001^{*}$ \\
\hline Social functioning & $72(70-75)$ & $55(48-56)$ & $<0,001^{*}$ \\
\hline Role emotional state & $77(74-79)$ & $40,5(37-45)$ & $<0,001^{*}$ \\
\hline Mental health & $80(72-82)$ & $42(38-45)$ & $<0,001^{*}$ \\
\hline General health & $69(60-72)$ & $44,5(43-55)$ & $<0,001^{*}$ \\
\hline
\end{tabular}

Note: $\mathrm{p}<0.001 *$ - means Mann-Whitney criterion allowed to reveal statistically significant discrepancies between 2 groups. 
Conclusions. Health parameters of patients suffering from chronic endometritis differ greatly from those of healthy women. High somatic pathology parameters and fertility issues can cause low scores of each life quality scale. Analysis of life quality which patients with this diseases have will allow to develop relevant recommendations aimed at its improvement and exerting positive influence on efficiency of the basic pathology therapy. Allowing for poor health of women suffering from chronic endometritis, we assume that doctors with all specialties should pay greater attention to medical-preventive activities, and prescribe health-preserving treatment at all the stages when a woman applies for medical aid, and not only when she is getting ready for a pregnancy. It is necessary to apply individualized sets of pharmaceuticals, physiotherapeutic and balneal techniques, as well as diet therapy, for the recovery of basic metabolism types, antioxidant processes, immunologic protection factors and non-specific reactivity. Healthpreserving treatment for not only gynecological but also concomitant somatic pathologies can stimulate adaptation reserves recovery in organs and systems, neuro-vegetative regulation, and, accordingly, hormonal homeostasis recovery which becomes truly vital for maintaining proper reproductive system functioning.

\section{References}

1. Demin A.V. Populyatsionnye pokazateli kachestva zhizni zhenshchin 65-74 let, prozhivayushchikh na Evropeiskom Severe Rossii [Population parameters of life quality characteristic for women aged 65-74 living in the Northern European part of Russia]. Molodoi uchenyi, 2015, no. 21, pp. 261-269. Available at: https://moluch.ru/archive/101/22786/ (09.07.2017) (in Russian).

2. Dolgikh O.V., Zaitseva N.V., Dianova D.G. Analiz apoptoticheskoi aktivnosti limfotsitov u zhenshchin fertil'nogo vozrasta $\mathrm{v}$ usloviyakh vozdeistviya reprotoksikantov [In women of childbearing age under the conditions of reprotoxicants exposure]. Rossiiskii immunologicheskii zhurnal, 2015, vol. 9, no. 1, pp. 58 (in Russian).

3. Loranskaya I.D., Rakitskaya L.G., Malakhova E.V., Mamedova L.D. Lechenie khronicheskikh kholetsistitov [Chronic cholecystitis treatment]. Lechashchii vrach: meditsinskii nauchno-prakticheskii portal, 2006. Available at: https://www.lvrach.ru/2006/06/4534015/ (10.08.2017) (in Russian).

4. Minasyan A. M., Dubrovskaya M. V. Beremennost' na fone khronicheskogo pielonefrita (obzor) [Pregnancy of a woman suffering from chronic pyelonephritis (a review)]. Saratovskii nauchno-meditsinskii zhurnal, 2012, vol. 8, no. 4, pp. 920-925 (in Russian).

5. Orazmuradov A.A., Boltovskaya M.N., Shmel'kov A.V., Apresyan S.V., Nazimova S.V., Terent'eva S.L. Negativnoe vliyanie khronicheskogo pielonefrita na protsess gestatsii [Negative impact of chronic pyelonephritis on the gestation]. Vestnik Rossiiskogo universiteta druzhby narodov. Seriya: Meditsina, 2011, no. S5, pp. 14-18 (in Russian).

6. Ovchinnikov A.Yu., Slavskii A.N., Fetisov I.S. Khronicheskii tonzillit i sopryazhennye s nim zabolevaniya [Chronic tonsillitis and concomitant diseases]. Russkii meditsinskii zhurnal, 1999, no. 7, pp. 31-36 (in Russian).

7. Bubnova O.A., Dolgikh O.V., Sinitsyna O.O., Krivtsov A.V., Bezruchenko N.V., Mazunina A.A., Gusel'nikov M.A., Otavina E.A. Polimorfizm genov semeistva ppars, gena esr1 u zhenshchin $\mathrm{s}$ nevynashivaniem beremennosti $\mathrm{v}$ usloviyakh aerogennoi ekspozitsii fenolami [Polymorphism of ppars genes and esr1 gene in females with miscarriages under aerogenous exposure to phenols]. Okruzhayushchaya sreda i zdorov'e. Gigiena i ekologiya urbaniziro- 
vannykh territorii: materialy VI Vserossiiskoi nauchno-prakticheskoi konferentsii s mezhdunarodnym uchastiem molodykh uchenykh i spetsialistov, posvyashchennoi 85-letiyu FGBU NII ECh i GOS im. A.N. Sysina Minzdrava Rossii [Environment and health. Hygiene and ecology on urbanized territories: materials of the VI Russian theory and practical conference with international participation of young scientists and experts dedicated to 85-th anniversary of Sytin's Scientific Research Institute for Human Ecology and Environmental Hygiene of the RF Public Healthcare Ministry]. In: Yu.A. Rakhmanin, ed. 2016, pp. 93-98 (in Russian).

8. Amirdzhanova V.N., Goryachev D.V., Korshunov N.I., Rebrov A.P., Sorotskaya V.N. Populyatsionnye pokazateli kachestva zhizni po oprosniku SF-36 (rezul'taty mnogotsentrovogo issledovaniya kachestva zhizni «MIRAZh») [SF-36 questionnaire population quality of life indices Objective]. Nauchno-prakticheskaya revmatologiya, 2008, no. 1, pp. 36-48 (in Russian).

9. Radzinskii V.E. Reproduktivnaya infektologiya XXI veka [Reproductive infectology in the XXI century]. StatusPraesens, 2013, no.16-5, pp. 33-36 (in Russian).

10. Fen I., Sidorova I.S., Stanoevich I.V., Unanyan A.L., Kudrina E.A. Sochetanie giperplasticheskikh protsessov endometriya s khronicheskim endometritom [Combination of endometrial hyperplastic processes with chronic endometritis]. Akusherstvo, ginekologiya i reproduktsiya, 2012, vol. 6, no. 1, pp. 31-33 (in Russian).

11. Motovilova T.M., Grechkanev G.O., Kachalina T.S., [et al.]. Sravnitel'naya kharakteristika mikroflory polosti matki i nebnykh mindalin u patsientok s persistiruyushchim endometritom [Comparative characteristics of microflora of uterine cavity and palatal tonsils in the case of female patients having persistent endometritis]. Meditsinskii al'manakh, 2015, no. 4 (39), pp. 105-107 (in Russian).

12. Sukhikh G.T., Shurshalina A.V. Khronicheskii endometrit [Chronic endometritis]. Moscow, GEOTAR-Mediya, Publ., 2010, 64 p. (in Russian).

13. Styazhkina S.N., Chernenkova M.L., Krivenko P.A., Gailyamova L.I. Techenie i iskhody beremennosti $\mathrm{u}$ zhenshchin $\mathrm{s}$ khronicheskim pielonefritom [The course of pregnancy and outcome of labor in women with chronic pyelonephritis]. Sovremennye problem nauki i obrazovaniya: elektronnyi nauchnyi zhurnal, 2015, no. 1-1. Available at: https://www.scienceeducation.ru/ru/article/view?id=17394 (12.07.2017) (in Russian).

14. Tkachenko L.V., Sviridova N.I. Prognosticheskie faktory riska razvitiya giperplasticheskikh protsessov endometriya v perimenopauzal'nom periode [Prognostic factors for the development of hyperplastic processes in perimenopause]. Volgogradskii nauchno-meditsinskii zhurnal, 2013, no. 4, pp. 43-47 (in Russian).

15. Chereshnev V.A., Gusev E.Yu. Immunologiya vospaleniya: rol' tsitokinov [Immunology of Inflammation: The Role of Cytokines]. Meditsinskaya immunologiya, 2001, vol. 3, no. 3, pp. 361-368 (in Russian).

16. Ware J.E., Snow K.K., Kosinski M., Gandek B. SF-36 Health Survey. Manual and interpretation guide. Boston, Mass: The Health Institute, New England Medical Center, 1993.

17. Ware J.E., Kosinski M., Keller S.D. SF-36 Physical and Mental Health Summary Scales: A User`s Manual. Boston, Mass: The Health Institute, New England Medical Center, 1994.

Kobaidze E.G., Padrul M.M. High risks of somatic pathology in women with chronic endometritis. Health Risk Analysis, 2017, no. 4, pp. 57-65. DOI: 10.21668/health.risk/2017.4.06.eng

Received: 08.09.2017

Accepted: 11.12.2017

Published: 30.12 .2017 
UDC 316.64

DOI: $10.21668 /$ health.risk/2017.4.07.eng

\title{
SOCIAL HEALTH AND PERCEPTION OF RISKS BY STUDENTS LIVING IN SOUTHERN RUSSIAN REGIONS (BASED ON SOCIOLOGICAL QUESTIONING DATA OBTAINED IN ROSTOV-ON-DON)
}

\author{
N.Kh. Gafiatulina ${ }^{1}$, L.V. Tarasenko ${ }^{1}$, S.I. Samygin ${ }^{2}$, S.Yu. Eliseeva ${ }^{3}$ \\ ${ }^{1}$ Southern Federal University, 105/42 Bolshaya Sadovaya Str., Rostov-on-Don, 344006, Russian Federation \\ ${ }^{2}$ Rostov State University of Economics, 69 Bolshaya Sadovaya Str., Rostov-on-Don, 344002, Russian Federation \\ ${ }^{3}$ Perm State University, 15 Bukireva Str, Perm, 614990, Russian Federation
}

We chose young students as our research object as they represent a social-demographic group with a specific social health, lifestyle, social activity, and social well-being. Our research goal was to assess students' social health and to determine how they perceived risks for it. Analysis of social health risks perception by young students was performed within socio-centric and sociogenic approaches as well as risk-examining paradigm. We considered social activity, social networks involvement, and social well-being as key aspects of social health. It is shown that young students mostly have average social health as per its integral index. But here we detected low social activity, high social networks involvement, and average social well-being. We singled out 3 typical groups of young students: "socially active integrated optimists", "socially passive moderately integrated pessimists", and "socially passive integrated optimists". All three students groups mentioned difficulties related to employment as important social health risk factors; however, it were respondents with low social health who were most preoccupied with "future uncertainty". Young students with low social health are to a greater extent preoccupied with risk factors causing personal danger for themselves than for a society as a whole.

It is necessary to create complex activities in a contemporary education space; these activates are to aimed at minimizing and preventing risks for Russian students' social health. We should make for higher social activity as it will inevitably lead to higher social well-being and improve overall students' social health.

Key words: young Russian students, social health, risks, risks perception, social activity, social networks involvement, social well-being.

The World Health Organization treats health as a phenomenon with a rather complicated nature and determines it as triune physical, psychological, and social welfare of a person. So, social welfare can be and should be considered a feature of a person's individual state. In the WHO experts' opinion, social health is a degree to which a person is satisfied with his or her social status, social connections and relations, material welfare, and living conditions. An antipode to social health is social deadaptation, social neglect, and deviation [21].

It is vital to study social health of young students as its parameters are indicative for assessing overall health risks, and they have "the significance for making a

(C) Gafiatulina N.Kh., Tarasenko L.V., Samygin S.I., Eliseeva S.Yu., 2017

Natalia Kh. Gafiatulina - Candidate of Sociological Sciences, Associate Professor, at Regional Sociology and Social Processes Modeling Department of Sociology and Regional Studies Institute, working for a doctor's degree (e-mail: gafiatulina@yandex.ru; tel.: +7 (8632) 18-40-00).

Larisa V. Tarasenko - Doctor of Sociological Sciences, Professor, Head of Regional Sociology and Social Processes Modeling Department of Sociology and Regional Studies (e-mail: tis_monti@mail.ru; tel.: +7 (8632) 1840-00).

Sergey I. Samygin - Doctor of Sociological Sciences, Professor at Human Resources Management and Sociology (e-mail: samygin78_yandex.ru; tel.: +7 (8632) 69-50-85).

Sofya Yu. Eliseeva - first-year student at MA courses, "Sociology" specialty at Philosophy and Sociology Faculty (e-mail: sonia.eliseeva@bk.ru; tel.: +7 (963) 017-37-13). 
young person's sociality really healthy and for making this phenomenon a scientifically regulated object" [11, p. 74]. When we characterize "social health" as a category, it is necessary to highlight that its semantic field is very wide and has a lot of meanings; it comprises a wide range of social, economic, psychological, cultural, and other parameters. T.Parsons and E.Fromm interpreted health as a social phenomenon with a complicated structure which formed due to interactions between various social groups or individuals and the society as a whole and reflected this or that level of such interactions [16, 18]. We noted that foreign researchers focused their attention on social health as a certain state of a personality, group, and society $[23,26]$.

Overall, representation of youth's social health in the scientific sociological discourse is related to issues of social activity which transforms types and forms of a group's or an individual's social mobility and involvement into the society into various social relations and connections. These issues attracted attentions of foreign and Russian sociologists [3, 9, 11, 12, 18, 20, 22, 24]. Thus, L.A. Baikova considers youth's social health through the prism of harmony in social connections and relationships with other people, society, and culture, which make for satisfying social needs and self-actualization of a young man's personality [3].

Scientific research in the youth sociology sphere, as well as in the sphere of its social health was performed by a number of Russian scientists [2, 6, 9, 10, 13, 14, 19]. A common conclusion is that when there is uncertainty and riskiness in the society, young students face a problem which life style to pursue as a form of their social self-determination and their selfactualization in life [17].
Overall, population health risks [4, 14], including those for young students' social health, evolve in the social interactions and "become behavioral determinants" [8].

M. Tobias, a contemporary foreign researcher, has examined risk factors for a personality social development and young people's health; he stresses, among other factors, a low social rank (social-economic status of young people) as being one of the most important. The scientist comes to a just conclusion that low social rank results in unhealthy life style and risks of increase in social insecurity. To solve this problem, M. Tobias suggests to make material wealth more accessible and to provide social support [25]. Such an approach will make for decrease in risks for youth's social development and health.

This article treats social health as a state determined by social activity and involvement into social contacts and reflecting a certain level of a social state. "Young students" as a social category within the socio-centric approach is a heterogeneous community with a variety of life styles, risks as its essential property, and different levels of social health [5].

Our research goal was to assess social health and perception of risks for it by young students.

Our research tasks were to analyze an individual's social activity, his or her involvement into social networks, and social well-being of young Russian students.

Data and methods. We analyzed perception of risks for young students' social health within the socio-centric and sociogenic approaches as well as within the riskology paradigm. Our research empiric base was the results of sociological questioning conducted among young students in Rostov region (the sampling comprised 369 people). We questioned students from 
the Southern Federal University, 130 people $(35.2 \%$ of the sampling); Donskoy State Technical University, 186 people (50.4\%); Rostov State Medical University, 47 people (12.7\%); and Rostov Regional Sport School of the Olympic Reserve, 6 people $(1.7 \%)$. The questioning was conducted in September - October 2016.

Respondents' age varied from 16 to 26 years: 145 were $16-18(39.3 \%$ of the sampling); 183, 19-21 (49.6\%); and 41, 22 and older $(11.1 \%) .37 .9 \%$ were males and $62.1 \%$ females. More than a half $(58.3 \%)$ were first-years students from humanitarian, technical, and natural sciences faculties.

A medical-social trend, namely integration of socio-centric and sociogenic approaches, gave methodological grounds for social health research. Socio-centric approach implies examining characteristics of a young personality's involvement into the society which provides its selfactualization, the society development, and harmonious interaction between a personality and the society [1]. Sociogenic approach implies examining influence exerted on health by characteristics of a personality involvement into the society, physical and mental welfare being determined by social health [5]. A combination of sociocentric and sociogenic approaches (as per terms suggested by L.V. Kolpina [12]) allows to explain objective and subjective features of youth social health. Objective criteria give the possibility to assess involvement into social contacts; and subjective ones, satisfaction with one's own social status and social health.

Our basic methodological benchmark was the thesis that social health characterizes not only the society as a whole or a social group, but also separate individuals, that is, it can be described on an individual level together with physical and mental health. We spotted the following components of individual social health:

a) an individual's social activity (is measured via involvement into work, social and political, cultural, and other activities);

b) involvement into social networks (is measured via social contacts intensity and membership in various organizations);

в) social well-being (is measured via satisfaction with a social status, social networks, "life as a whole").

Students' social activity was assessed via their participation in the social life of their HEE and city, volunteer activities and social and political activities, participation in religious organizations activities. Activity in these spheres was considered to be "high" if a respondent got him or herself involved into it "often" or "from time to time"; it was considered to be "average" if respondents did it "rarely"; it was considered to be "low", if a respondent stated he or she "never did that". Analysis of answers simple distributions revealed that $73.4 \%$ respondents never took any part in social and political activities, and $83.2 \%$ students never participated in any religious organizations activities. As these activity types turned out to be rather alien for most students they were excluded from our further analysis.

Involvement into social networks was measured via frequency of a student's socializing with a) his or her family: b) his or her friends. Involvement into social networks was assessed as "high" if a respondent chose a variant "I socialize quite often"; it was assessed as "average" if they chose "socialize from time to time"; and it was assessed as "low", if the answers were "rarely" and "never".

Social well-being was characterized on the basis of assessments respondents gave to the quality of their social relations (in- 
teractions with such reference groups as families, friends, and fellow students). Social well-being was assessed as "high" ("good") for respondents who, when answering "How do you estimate your relations with various groups of people?" question, chose "excellent"; it was assessed as "average" for those who chose "good": and it was assessed as "low" ("bad") for those who chose "satisfactory" or "bad".

An index for each component of social health was calculated as per formula:

$$
I_{i}=\frac{a_{1}+a_{2}+a_{n}}{n},
$$

where $I_{i}-$ is and index for an i-th component of social health; $a_{n}-$ is a value of a $\mathrm{n}$-th variable characterizing a component (values are equal to "1", "2", or " $3 ") ; n-$ is a number of variables which characterize a component.

For example, social activity index $\left(I_{\text {акт }}\right)$ was calculated as a simple average of three components: participation in a city social life, participation in a HEE social life, and participation in volunteer activities. If a respondent stated he or she frequently participated in a HEE social life (variable value being equal to "1"), rarely participated in volunteer activities (variable value being equal to "2"), and almost never participated in a city social life (variable value being equal to "3"), then his or her $I_{\text {act }}$ amounted to "2".

Value of each index varied from 3 (a component evidence is minimal, that is, a respondent is socially passive / isolated from a social network / his social wellbeing is low) to 1 (a component evidence is maximum, that is, a respondent is socially active / he is integrated into social networks / his social well-being is high).

We performed a cluster analysis ( $\mathrm{k}$ averages techniques) basing on values of social health components indexes; it al- lowed us to distribute students into groups depending on their social health peculiarities. We also calculated an integral social health index as a simple mean of its three components. Index value from 1 to 1.25 indicated social health was good; from 1.26 to 1.75 , above average; from 1.76 to 2.25 , average; from 2.26 to 2.75 , below average; from 2.76 to 3 , poor social health and social insecurity risks for an individual. That is, the higher social health integral index is, the better and individual is integrated into social environment, adapted to it, and the higher his socio-cultural potential is.

We applied correlation analysis to characterize how young students perceived risks for their social health. We detected correlations between: a) an integral index of a student's social health, b) a respondent belonging to this or that cluster, and c) a respondent assessing this or that social problem as " dangerous".

To assess risk perception, students were offered a list of 12 factors causing social health disorders risk. Each respondent could choose not more than 6 factors which he or she considered to be "dangerous".

Results and discussion. The preformed analysis revealed that students' social health had the following features: low social activity, substantial involvement into social networks, and average social wellbeing.

A share of students who often took part in various social activities didn't exceed $10 \%$ per each type. Thus, only $4.3 \%$ respondents often participates in social life of their city, and $10.6 \%$ did it from time to time. $7.6 \%$ often participated in their HEE social life, $22.2 \%$ did it from time to time. This social activity was the most popular among students. Only 3.0\% respondents were often involved into volunteer activities, and $17.3 \%$, from time to time. $33.9 \%$ students were totally isolated from their 
HEE social life (chose "never participate" variant); $54.7 \%$, from their city social life; $52 \%$ never took part in any volunteer activities.

As we calculated students' social activity index, we got values ranging from "1" (maximum activity, $8.4 \%$ respondents) to "3" (minimum activity, 24.7\% respondents).

Students most frequently communicated with their friends as $85.9 \%$ respondents said they did it often. $12.7 \%$ chose "from time to time" variant; $1.4 \%$, rarely. The obtained data on high students' involvement into interaction with their peers are quite natural and reflect peculiarities of social connections and attitudes in this social group. Less than half students (48.2\%) noted that they "frequently communicated with their family members less than with their friends"; $36.3 \%$, "from time to time"; $14.1 \%$, "rarely"; and 1.4\%, "never".

Maximum value of index showing involvement into social networks ("1") was characteristic for $45.5 \%$ respondents; and minimum ("3"), for only $0.5 \%$ of the sampling.

Most students assessed their relations with friends quite positively: $63.7 \%$ said they were excellent, $28.2 \%$ stated they were good. $46.9 \%$ and $42 \%$ students correspondingly gave the same assessments for their relations with their family members.

Respondents' relations with their fellow students can be considered the least satisfactory as only $12.5 \%$ said "they were excellent", 48.8 stated "they were good", and $34.7 \%$, "satisfactory".

More than a half values of social wellbeing index (58.7\%) are concentrated in "high" zone ranging from 1 to 1.67 , the least possible value ("3") was fixed only for $2.7 \%$ students.

Clustering allowed to detect 3 clusters (Table 1). Students from the first cluster
(35.7\% of the sampling) had the best social health as the cluster end center as per social activity index was equal to 1.56 , social networks involvement index was equal to 1.21, and social well-being index was equal to 1.57. Students from this cluster can be called "socially active integrated optimists". Share of students belonging to this cluster was practically the same among male and females students, 37.2\% and $34.8 \%$ correspondingly.

Students from the second cluster (26.6\% of the sampling) - so called "socially passive moderately integrated pessimists" - have low social activity (the cluster end center is 2.55) combined with poor social well-being (the cluster end center as per this component is 2.27) and average involvement into social networks (index value is 1.92). Young male students authentically more frequently belong to this cluster than young females, $33.6 \%$ against $22.3 \%$ correspondingly.

Students from the third cluster $(37.7 \%$ of the sampling) are well involved into social networks just as students from the first cluster (the cluster end center as per social network involvement index is 1.23) and have good social well-being (the cluster end center as per this index is equal to 1.59). However, social activity level in this cluster is very low (the cluster end center as per social activity index is 2.7). This students' group can be called "socially passive integrated optimists" and there are more girls among them than boys. $42.9 \%$ female respondents belong to it and only $29.2 \%$ male respondents. Calculation of the integral index showing students' individual social health (index value ranging from 1 to 1.25 ) revealed that only $8.3 \%$ students had good social health, and $36.3 \%$, above average. $41.8 \%$ students had only average social health, and $13.6 \%$, below average. 
Table 1

Median values of social health components in the detected clusters

\begin{tabular}{|l|c|c|c|}
\hline \multirow{2}{*}{$\begin{array}{c}\text { Social health } \\
\text { components }\end{array}$} & \multicolumn{3}{|c|}{ Median value of a components in clusters } \\
\cline { 2 - 4 } & $\begin{array}{c}\text { 1 cluster (35.7\%) } \\
\text { "Socially active integrated } \\
\text { optimists" }\end{array}$ & $\begin{array}{c}\text { 2 cluster (26.6\%) } \\
\text { "Socially passive moderately } \\
\text { integrated pessimists" }\end{array}$ & $\begin{array}{c}3 \text { cluster (37.7\%) } \\
\text { "Socially passive } \\
\text { integrated optimists" }\end{array}$ \\
\hline Social activity & 1,56 & 2,55 & 2,7 \\
\hline $\begin{array}{l}\text { Social networks in- } \\
\text { volvement }\end{array}$ & 1,21 & 1,92 & 1,23 \\
\hline Social well-being & 1,57 & 2,27 & 1,59 \\
\hline
\end{tabular}

We detected statistically significant $(\mathrm{p}<0.001)$ weak positive correlation (Pearson correlation coefficient is equal to 0.22 ) between social health level and a respondent's self-esteem of his or her physical health. Respondents with different social health level perceived risk factors which were important for them in a different way.

We examined a correlation between an integral index showing individual social health and a respondent choosing this or that factor as a significant one and detected that respondents with low social health were more preoccupied with "future uncertainty" (Pearson correlation coefficient was equal to 0.117 with $\mathrm{p}<0.05)$. This group of respondents was also more preoccupied with social insecurity threat than other groups (Pearson correlation coefficient was equal to 0.1 with $\mathrm{p}<0.06$ ).

The obtained data are confirmed with the results of the research conducted by the Russian Public Opinion Research Center (VCIOM) in June 2017. As per this research results, health index and personal safety (security) nowadays holds the leading place among life priorities of Russians (Table 2). And as we can see from it, significance attributed to personal safety and health has been growing steadily according to comparative data analysis as per this parameters over previous years [7].
As per our research results, there was a statistically significant correlation (as per chi-square criterion) between belonging to a certain cluster and choice of increase in poverty $(0.14$ at $p<0.05)$ and future uncertainty $(0.14$ at $p<0.01)$ as disturbing troubles. The first threat was authentically more frequently mentioned by students from the most "socially healthy" cluster, and the second one, by those form the least "socially healthy".

Shares of respondents who perceived this or that risk factor as a significant one in different clusters are shown in Table 2.

Totally, we can note that respondents with lower social health are more preoccupied with threats for themselves than for the society as a whole as opposed to students with better social health parameters.

As can see from the Table 3, such factor as difficulties with recruitment is viewed as the most serious threat in all clusters; it was chosen as "a dangerous one" by $53 \%$ respondents from the first cluster, by $48 \%$, from the second, and by $54 \%$, from the third one. We didn't detect any authentic discrepancies between clusters. Students also had the same attitudes towards traditional values destruction; it was considered a threat by $39 \%$ respondents in the first cluster, by $37 \%$, in the second, and $36.8 \%$, in the third one. 
Table 2

"VCIOM-Sputnik" all-Russian pilot questioning results (14-15 May 2017)[7]

\begin{tabular}{|l|c|c|c|c|c|c|c|}
\hline \multicolumn{7}{|c|}{ How significant are the following aspects of your life for you personally? } \\
(closed question, one answer, index in scores) \\
\hline \multicolumn{1}{|c|}{ Параметр } & 2005 & 2006 & 2007 & 2008 & 2009 & 2014 & 2017 \\
\hline $\begin{array}{l}\text { Your own health and health of your } \\
\text { family members (index) }\end{array}$ & $98^{*}$ & 94 & 93 & 96 & 97 & 95 & $\mathbf{9 9}$ \\
\hline Family relations (index) & 97 & 94 & 94 & 96 & 97 & 97 & $\mathbf{9 8}$ \\
\hline $\begin{array}{l}\text { You personal safety and safety of your } \\
\text { family (index) }\end{array}$ & 96 & 94 & 93 & 96 & 97 & 97 & $\mathbf{9 6}$ \\
\hline
\end{tabular}

N o t e: * -Respondents could assess a factor significance as per scale from-100 (totally insignificant) to 100 (very significant)

Table 3

Risk perception by respondents with different social health levels

\begin{tabular}{|c|c|c|c|}
\hline \multirow{2}{*}{ Risks } & \multicolumn{3}{|l|}{ A share of respondents considering a threat to be signifi- } \\
\cline { 2 - 4 } & 1 cluster $(\%)$ & 2 cluster & 3 cluster \\
\hline Traditional values destruction & 39,5 & 37,5 & 36,8 \\
\hline Social stratification into poor and rich & 31,0 & 20,8 & 19,9 \\
\hline Poverty growth & 32,6 & 24 & 18,4 \\
\hline Difficulties with recruitment & 53,5 & 47,9 & 54,4 \\
\hline Unemployment growth & 27,9 & 20,8 & 19,9 \\
\hline Social insecurity & 13,2 & 20,8 & 19,9 \\
\hline Social and political instability & 20,9 & 14,6 & 15,4 \\
\hline National and religious conflicts & 23,3 & 21,9 & 22,8 \\
\hline Social injustice growth & 15,5 & 22,9 & 20,6 \\
\hline Soullessness and immorality & 26,4 & 26,0 & 36,0 \\
\hline Credibility crisis & 20,9 & 14,6 & 17,6 \\
\hline Future uncertainty & 22,5 & 33,3 & 18,4 \\
\hline
\end{tabular}

Besides all that, each fifth student from the second and the third cluster marked social injustice growth as a risk factor (as opposed to students from the first cluster who thought this factor was insignificant). Perhaps, ideas about injustice are rather personified. But still the same young people are much less preoccupied with overall unemployment growth (14.8 respondents from the third cluster thought it was significant as opposed to $27.9 \%$ respondents from the first cluster). Respondents from the third cluster are the least preoccupied with overall poverty growth (two times less than in the first cluster), social stratification in the society, and political 
instability. Therefore, we can say that a thesis on private problems priority for respondents from the "socially passive..." group.

\section{Conclusions and recommendations.}

Therefore, social health is a phenomenon which reflects different aspects of life and it requires comprehensive and profound scientific examination with obligatory generalization of theoretical and applied data related to contemporary practicalities in the sphere [15]. The sociological research which considered social activity, social networks involvement, and social well-being as key aspects of young students' social health revealed that:

- calculation of the integral index showing individual social health of young students proves that most respondents have average social health; young students' social health has the following features: low social activity, high social networks involvement, and average social well-being;

- we spotted out 3 typical groups of young students: "socially active integrated optimists", "socially passive moderately integrated pessimists", and "socially passive integrated optimists";
- all students' group mark difficulties with recruitment as significant social risk factors; however, "future uncertainty" preoccupies respondents with low social health more that those with high one;

- young students with low social health are more preoccupied with risk factors which are dangerous for themselves that for the society as a whole.

In contemporary educational environment it is necessary to work out complex activities aimed at minimization, prevention and prophylaxis of risks for young students' social health. In particular, it is necessary to make for greater social activity and decrease in social networks involvement as it will undoubtedly lead to better social well-being and better social health in general. As a social aspect of young people's health influences their overall health and is realized via social connection and relations, it is necessary to promote social health support both at regional and federal levels. This statement confirms all the results obtained in the previous research [22] and conclusions saying that societies with high social health has a distinctive feature of the highest informal support being given to all their members.

\section{References}

1. Anisimov A.I., Kireeva N.N. Psikhologicheskoe obespechenie sotsial'nogo zdorov'ya uchitelei [Psychological provision of teachers' social health]. Psikhologiya obucheniya, 2012, no. 4, pp. 100-114 (in Russian).

2. Babintsev V.P., Ushamirskii A.E. Rossiiskaya molodezh': sotsializatsiya kak sotsial'naya adaptatsiya [Russian youth: socialization as social adaptation]. Nauchny evedomosti Belgorodskogo gosudarstvennogo universiteta. Seriya: Filosofiya. Sotsiologiya. Pravo, 2016, vol. 37, no. 17 (238), pp. 85-89 (in Russian).

3. Baikova L.A. Sotsial'noe zdorov'e detei i molodezhi: metodologiya, teoriyaipraktika: monografiya [Social health of children and youth: methodology, theory, and practice: monograph]. Ryazan', 2011, 224 p. (in Russian).

4. Barg A.O., Lebedeva-Nesevrya N.A. Risk-kommunikatsiya kak mekhanizm formirovaniya adekvatnoi otsenki riskov dlya zdorov'ya naseleniya[Risk-communication as an effective way of producing the cumulative acceptability of human health risks]. Zdorov'e naseleniya $i$ sreda obitaniya, 2014, vol. 12, no. 261, pp. 9-11 (in Russian). 
5. Gafiatulina N.Kh. Sotsial'noe samochuvstvie molodezhi v usloviyakh riskogennosti rossiiskogo obshchestva [Social self sensitiveness of the youth in the terms of risk of the russian society]. Lichnost' $v$ ekstremal'nykh usloviyakh $i$ krizisnykh situatsiyakh zhiznedeyatel'nosti, 2011, no. 1, pp. 17-24 (in Russian).

6. Gorshkov M.K., Sheregi F.E. O zhiznennykh planakh rossiiskoi molodezhi: nastoyashchee I budushchee [On life plans of Russian youth: present and future]. Rossiya i Kitai: molodezh' XXI veka. In: M.K. Gorshkov, F.E. Sheregi [et al.], eds. Moscow, 2014, pp. 384-404 (in Russian).

7. Zhiznennye prioritety rossiyan: sem'ya, den'gi ili tvorchestvo? [Life priorities of Russians: family, wealth, or creation?]. Vserossiiskii tsentr izucheniya obshchestvennogo mneniya, 2017, Press-vypusk no. 3391. Available at: https://wciom.ru/index.php? id=236\&uid=116264 (24.08.2017) (in Russian).

8. Zaitseva N.V., Lebedeva-Nesevrya N.A. Podkhody k postroeniyu effektivnoi regional'noi sistemy informirovaniya o riskakh zdorov'yu [Methodological approaches to building of regional system of health risks information]. Zdorov'e sem'i - 21 vek, 2010, no. 4, pp. 8 (in Russian).

9. Zobov R.A., Kelas'ev V.N. Zhiznennyi uspekh i orientatsii sovremennoi rossiiskoi molodezhi [Success in life and orientations of contemporary Russian youth]. Molodezhnaya Galakti$k a, 2013$, no. 9, pp. 20-28 (in Russian).

10. Zubok Yu.A., Chuprov V.I. Sovremennaya sotsiologiya molodezhi: izmenyayushchayasya real'nost' i novye teoreticheskie podkhody [Modern sociology of youth: changing reality and theoretical approaches]. Rossiya reformiruyushchayasya, 2017, no. 15, pp. 12-48 (in Russian).

11. Kolpina L.V. Sotsial'noe zdorov'e: opredelenie i mekhanizmy vliyaniya na obshchee zdorov'e: obzor literatury [Social health: definition and mechanisms of influence on individual health: literature review]. Sinergiya, 2017, no. 2, pp. 73-81 (in Russian).

12. Kolpina L.V., Serbai I.N. K voprosu ob opredelenii ponyatiya «sotsial'noe zdorov'e» [On "social health" concept].Srednerusskii vestnik obshchestvennykh nauk, 2011, no. 1, pp. 4956 (in Russian).

13. Konstantinovskii D.L., Voznesenskaya E.D., Cherednichenko G.A. Rabochaya molodezh' segodnya: obrazovanie, professiya, sotsial'noe samochuvstvie [Workers Today: Education, Profession, Social Health]. Sotsiologicheskaya nauka i sotsial'naya praktika, 2013, no. 2, pp. 21-38 (in Russian).

14. Lebedeva-Nesevrya N.A. Sotsial'nye factory riska zdorov'yu kak ob"ekt upravleniya [Social health risk factors as an object of management]. Vestnik Permskogo universiteta. Seriya: Biologiya, 2010, no. 3, pp. 36-41 (in Russian).

15. Tarasenko L.V., Nor-Arevyan O.A., Kirik V.A. [et al.]. Modelirovanie professional'noi sotsializatsii studencheskoi molodezhi v usloviyakh sotsial'noi neopredelennosti [Modeling of students' professional socialization under social uncertainty]. Rostov on Don, 2016, 164 p. (in Russian).

16. O chem mechtayut rossiyane (razmyshleniya sotsiologov): Analiticheskii doklad [What Russians dream about (sociologists' thinking): analytical report]. Moscow, ISRAN, Publ., 2012, 106 p. (in Russian).

17. Parsons T. Sistema sovremennykh obshchestv [A system of modern societies]. Moscow, Aspekt-Press, Publ., 1997, 270 p. (in Russian).

18. Fromm E. Zdorovoe obshchestvo [A healthy society]. Moscow, Ast, Astrel', Publ., 2011, 314 p. (in Russian).

19. Shilkina N.E. Kontseptsiya tselevoi tsennosti deistviya kak teoretiko-metodologicheskoe osnovanie otsenki i prognoza sotsial'noi adaptatsii studencheskoi molodezhi v usloviyakh sotsial'noi neopredelennosti i riska [A target action value concept as theoretical and methodological 
grounds for assessing and predicting young students' social adaptation under social uncertainty and risks]. Devyatye Kovalevskie chteniya. Sotsiologiya i sotsiologicheskoe obrazovanie v Rossii: materialy konferentsii, posvyashchennoi 25-letiyu sotsiologicheskogo obrazovaniya $v$ Rossii $i$ Sankt-Peterburgskom gosudarstvennom universitete [The ninth Kovalev's readings. Sociology and sociological education in Russia: materials of the conference, dedicated to the 25th anniversary of sociological education in Russia and in saint Petersburg State University]. St. Peterburg, Skifiyaprint, Publ., 2014, pp. 229-231 (in Russian).

20. Berkman L.F., Kawachi I. Social epidemiology. New York, Oxford University Press, Publ., 2000, pp. 174-190.

21. Closing the gap in a generation: Health equity through action on the social determinants of health.World Health Organization: Commission on the Social Determinants of Health. Geneva, 2008, $256 \mathrm{p}$.

22. Hanefeld J., Vearey J., Lunt N. A global research agenda on migration, mobility, and health. The Lancet, 2017, vol. 389, no. 10087, pp. 2358-2359.

23. Herzman C., Boyce T. How experience gets under the skin to create gradients in developmental health. Annu. Rev. Public. Health, 2010, vol. 31, pp. 329-347.

24. Manor O., Matthews S. Power Health selection: The role of inter-and intragenerational mobility in social inequalities in health. Soc. Sci. Med., 2003, vol. 57, pp. 2217-2227.

25. Tobias M. Social rank: a risk factor whose time has come? The Lancet, 2017, vol. 389, no. 10075, pp. 1172-1174.

26. Trenton D. Mize Profile in health: Multiple roles and healthy lifestyles in early adulthood. Social Science \& Medicine, 2017, vol. 178, pp. 196-205.

Gafiatulina N.Kh., Tarasenko L.V., Samygin S.I., Eliseeva S.Yu. Social health and perception of risks by students living in southern russian regions (based on sociological questioning data obtained in Rostov-on-Don). Health Risk Analysis, 2017, no. 4, pp. 66-75. DOI: 10.21668/health.risk/2017.4.07.eng

Received: 10.07.2017

Accepted: 18.12.2017

Published: 30.12 .2017 


\title{
MEDICAL AND BIOLOGICAL ASPECTS OF THE ASSESSMENT OF THE RISK FACTORS
}

UDC 612.0-14.41-14.43

DOI: $10.21668 /$ health.risk/2017.4.08.eng

\section{INFLUENCE EXERTED BY RISK FACTORS OF SPACE AND ERATH WEATHER ON FREQUENCY OF EMERGENCY CALLS FROM PATIENTS WITH ACUTE CER- EBRAL CIRCULATION DISORDERS}

\author{
V.A. Belyaeva \\ Institute of Biomedical Research of Vladikavkaz Scientific Center of the Russian Academy of Sciences \\ and the Government of the Republic of North Ossetia-Alania, 47 Pushkinskaya Str., Vladikavkaz, 362025, \\ Russian Rederation
}

High morbidity with cardiovascular pathology increases loads on a public healthcare system and is not only social but also an economic problem. To optimize cardiovascular pathology prevention, it is necessary to thoroughly analyze risk factors which cause its occurrence. Our research goal was to examine a dynamics of acute cerebral circulation disorders depending on meteorological factors and heliofactors allowing for a seasonal component. We performed a retrospective analysis of morbidity with acute cerebral circulation disorders in winter, spring, and summer in 2012 on the basis of the archives obtained from an emergency station in Vladikavkaz. We analyzed 509 cases of the disease (294 women and 215 men). On the basis of our analysis results we assessed influence exerted by external factors on frequency of applications to emergency from patients with acute cerebral circulation disorders. We analyzed meteorological factors and heliofactors and their derivatives: average daily temperature, air pressure, relative humidity, wind speed, cloud coverage, weather pathogenicity, Sun radiation flux density at a wave length equal to 10.7, and a number of sunspots.

We detected that in winter negative influence was exerted by temperature; there was also a multi-factor dependence between frequency of acute cerebral circulation disorders and such predictors as temperature pathogenicity index and speed of changes in Sun radiation flux density during a day $\left(R_{\text {multi }}=0.50 ; R^{2}=0.25\right)$. Drastic temperature fluctuations make for increase in morbidity in spring. Morbidity cases frequency in women in this period correlates not only with temperature pathogenicity index but also with pathogenicity index of air pressure changes. Morbidity increase in summer is caused by simultaneous drop both in air pressure and relative humidity $\left(R_{\text {multi }}=0.59 ; R^{2}=0.35\right)$. Overall, correlation between external factors and morbidity with acute cerebral circulation disorder has seasonal specificity in different seasons. The obtained data make it possible to predict unfavorable influences exerted by meteorological factors and heliofactors allowing for seasonal dynamics and to plane prevention activities.

Key words: acute cerebral circulation disorders, seasonal morbidity, emergency, patient, risk factors, meteorological factors, heliofactors.

Cardiovascular diseases hold the first place in terms of worldwide prevalence and are the most widely spread mortality cause. Issues related to meteotropic reactions of a healthy and especially of a sick person have great medical and social sig- nificance due to the fact that the cardiovascular system is the basic target under exposure to external environmental factors [6, 14]. Various phenomena associated with solar physics are considered to be a stress factor for a body as they are able to cause

(C) Belyaeva V.A., 2017

Viktoriya A. Belyaeva - Candidate of Biological Sciences, researcher at New Medical Technologies and Regenerative Medicine Department (e-mail: pursh@inbox.ru, tel.: +7 (8672) 53-96-29). 
exacerbation of an already existing pathology [7, 9]. A number of hemorrhagic strokes, subarachnoid hemorrhages, and intra-cerebral hematomas is known to grow considerably during periods when the Sun is active $[4,8]$.

Seasonality factor plays a great role in cardiovascular pathology occurrence and evolvement. Seasonal changes in the nature are an integral part of the environment, and fluctuations in environmental factors which are attributable to them become conditioned reflex significant [5]. Some researchers note that morbidity with acute cerebral circulation disorder (ACCD) grows in autumn and winter [18, 20,21]. But some insist that a number of acute cerebral circulation disorders grows in spring and summer $[16,17]$. And, finally, there are works which don't contain any data on detected seasonal dynamics in morbidity with this pathology [13]. Such great differences in existing data require further research in the field and development of prevention techniques aimed at decreasing risks of such a grave disease as acute cerebral circulation disorder. It is necessary to examine and to predict influences exerted by meteorological and heliophysical factors on morbidity with acute cerebral circulation disorders when we plan emergency stations functioning in various geographical regions.

Our research goal was to examine dynamics in acute cerebral circulation disorders frequency depending on meteorological and heliofactors allowing for the seasonal component.

Data and methods. We performed a retrospective analysis of the archive data provided by an emergency station in Vladikavkaz in winter, spring, and summer 2012. We analyzed frequency of emergency calls related to acute cerebral circulation disorders depending on meteorolog- ical and heliofactors in the examined period. There were 509 acute cerebral circulation disorder cases fixed in the period (294 women and 215 men). Average daily emergency calls related to the examined pathology was equal to $3.2 \pm 0.22$ patient/day. There were more calls from women than from men $(1.8 \pm 0.14$ against $1.3 \pm 0.14 ; \mathrm{t}=2.56 ; \mathrm{p}=0.010)$. Average age of patients was $71.4 \pm 0.5$ (women were $72.6 \pm 0.7$; men, $69.7 \pm 0.7$ ). Correct and prompt diagnostics of acute cerebral circulation disorder as such is a basic task at the pre-hospital stage as it is extremely vital to render proper medical assistance within a "therapeutic window" [3]; therefore, our research tasks didn't include an exact determination of a stroke nature. Moreover, it is next to impossible to determine its nature when the first medical aid is rendered as there are no diagnostic signs which are characteristic only for ischemic or hemorrhagic acute cerebral circulation disorder. A stroke nature is usually determined only in hospital via computer tomography or magnetic resonance imaging of the brain [10].

Meteorological parameters (average daily temperature $(0 \mathrm{C})$, air pressure $(\mathrm{gPa})$, relative humidity $(\%)$, wind speed $(\mathrm{m} / \mathrm{sec})$, cloudiness (scores)) were obtained on the web-site "Weather Schedule" (http://www.rp5.ru) maintained by Vladikavkaz meteorological station.

Apart from the absolute parameters we determined certain weather pathogenicity indexes which reflected negative influence exerted by fluctuations in temperature (it), humidity (ih), wind speed (iv), cloudiness (in), and air pressure (ip), as well as changes in these parameters in different days.

Pathogenicity indexes show how pathogenic this or that specific meteorological situation is for patients; they are determined as a mathematical function of 
changes between days and deviations of basic meteorological parameters from their optimal values. Formulas for their calculation are given in the works by V.G. Boksh and B.V. Bogutskiy [2]. When meteorological parameters are at their optimal values or when pathogenic parameters are equal to zero, the weather doesn't cause any negative reactions in a body, and changes in any parameter in any direction lead to an increase in pathogenicity indexes and negative reactions risks which are proportionate to them.

We also analyzed the following heliofactors: the Sun radiation flux density at a wave length equal to $10.7 \mathrm{~cm}$ (s.r.f.), a number of sunspots (SSN), as well as their derivatives, namely parameters values which determined speed of their changes ($3,-2,-1$ days prior to measuring). Numeric values of the parameters were taken from SPIDR (Space Physics Interactive Data Resource) international database.

We performed statistical analysis of the data with the help of Statistica 6.0. To compare average values in two independent groups, we applied Student's t-criterion. We assessed influence exerted by external factors on frequency of emergency calls from patients with acute cerebral circulation disorders via correlation and regression analysis. Critical significance in statistical hypotheses verification was taken as equal to $\leq 0.05$.

Results and discussion. Analysis of all-season correlations between frequency of emergency calls from patients with acute cerebral circulation disorders and meteorological factors over the whole examined period revealed that there was a correlation on the whole ACCD sampling with average daily temperature $(\mathrm{r}=0.23$; $\mathrm{p}=0.008)$ and relative humidity $(\mathrm{r}=-0.20$; $\mathrm{p}=0.007)$. Having divided the sampling as per sex, we detected that correlation with the temperature factor in the whole sampling structure was caused by increase in ACCD morbidity in women when the temperature grew $(\mathrm{r}=0.19 ; \mathrm{p}=0.03)$; while correlation with relative humidity was caused by increasing morbidity of men when humidity dropped $(r=-0.19 ; p=0.023)$.

Further seasonal analysis of correlations between frequency of emergency calls and the examined factor reveled there was seasonal specificity, and correlation coefficients values were even higher. In winter we detected correlation between ACCD morbidity and speed of changes in the Sun radiation flux density during a day (s.r.f. $(-1))(\mathrm{r}=0.42 ; \mathrm{p}=0.009)$, and also average daily temperature $(\mathrm{r}=-0.39 ; \mathrm{p}=0.012)$. There was a growing trend in frequency of emergency calls when temperature pathogenicity index (it) grew $(\mathrm{r}=0.38 ; \mathrm{p}=0.06)$. Therefore, we can conclude, that morbidity with ACCD grows when temperature drops and also when there are drastic fluctuations in the Sun radiation density flux during a day.

Mechanisms of influences exerted by meteorological factors, heliofactors, and geomagnetic ones on a human body have not been fully examined so far since different levels of its structural and functional organization are involved into reactions evolving as a response to these influences. Increase in morbidity with cardiovascular pathology is supposed to result from adaptation desynchronosis [15]. In particular, when low temperatures exert their impacts on weakened patients with reduced body adaptation reserves and with already existing cardiovascular pathology, it leads to greater vasoconstrictors production and arterial stiffness as sympathetic nervous system becomes more active; consequently, hypertensive reactions occur. Due to it cardiovascular disasters risk increases considerably [19]. Increase in mortality caused by 
this pathology is usually detected in winter [12].

We should take into account that various meteorological and solar physics factors interact with each other and can act as synergists or antagonists thus changing body responses [1]. We performed multiple regression analysis which allowed us to detect multiple correlation $\left(R_{\text {mult }}=0,50\right.$; $\left.R_{\text {mult }}^{2}=0,25\right)$ between ACCD morbidity and the following predictors: it $(\mathrm{p}=0.016)$, s.r.f. $(-1)(\mathrm{p}=0.01)$, and to create ACCD morbidity model in winter time (Figure 1). (left axis: ACCD morbidity).

As we can see from the Figure 1, when weather pathogenicity index and speed of changes in the Sun radiation flux density grow simultaneously during a day, morbidity with acute cerebral circulation disorders, that is, these factors act as synergists in this case.

In spring we detected a positive correlation between ACCD morbidity and temperature pathogenicity index $(\mathrm{r}=0.26 ; \mathrm{p}=0.05)$. Drastic fluctuations in average daily temperature cause more frequent emergency calls from patients suffering from ACCD. We also detected that in spring ACCD morbidity in women correlated positively not only with temperature pathogenicity index (it) $(\mathrm{r}=0.29$; $\mathrm{p}=0.028$ ), but also with pathogenicity index of air pressure changes $(\mathrm{i} \Delta \mathrm{p}) \quad(\mathrm{r}=0.31$; $\mathrm{p}=0.019)$. As climate has been rather unstable over the last years, substantial differences in meteorological factors are detected in this region in spring and summer, and it causes greater information loads on a body and adaptation mechanisms stress [11].

We detected negative correlation between ACCD morbidity and the following meteorological factors: air pressure $(\mathrm{r}=-0.48 ; \mathrm{p}=0.0116)$ and relative humidity $(r=-0.34 ; p=0.047)$ in summer.

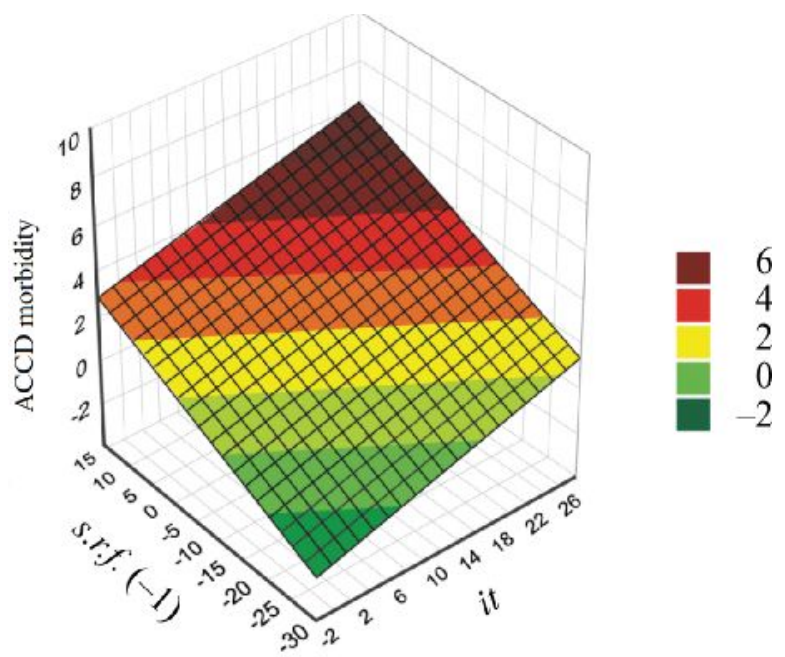

Figure 1. Correlation between ACCD morbidity and weather pathogenicity index (it) and speed of changes in the Sun radiation flux density during a day (s.r.f.(-1)) in winter

(3D ACCD surface graph (men/day) $=$ $1,374+0,113 * x+0,1081 * y)$.

Decrease in air pressure causes lower partial oxygen content in the air and it can cause hypoxic reactions in a body which become obvious via weakness, somnolence, dyspnea, and ischemic pains with different localization [2]. It is also known that as air pressure drops, a number of thrombocytes grows, and blood clotting period becomes shorter [1]. Allowing for the geographical position of Vladikavkaz which is located from 659 to 732 meters above sea level we can state that negative influence exerted by this factor is even more apparent and can cause increase in morbidity with cardiovascular pathology. Further multiple regression analysis revealed that dependence of emergency calls frequency on air pressure and humidity was a multi-factor one. Morbidity with ACCD grew at simultaneous decrease in air pressure $(\mathrm{p}=0.002)$ and relative humidity $(p=0.009)$ (Figure 2$)$. 


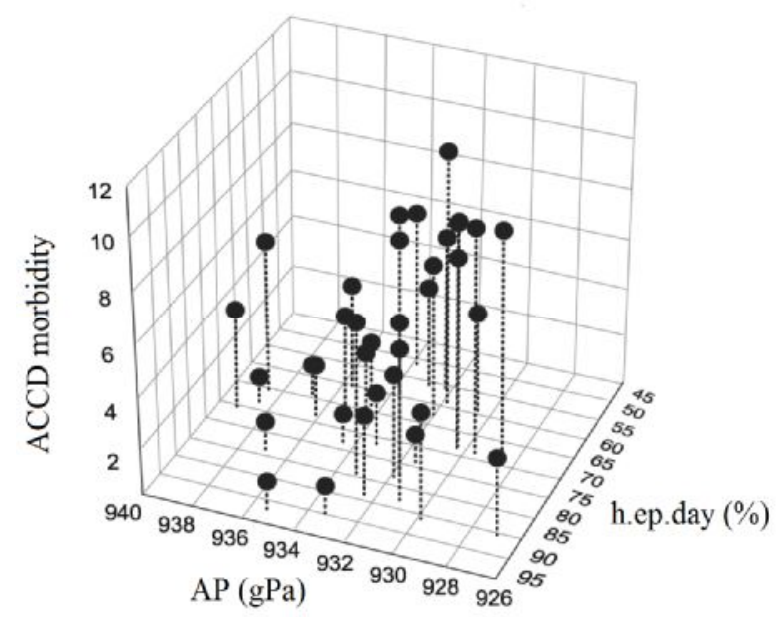

Figure 2. Correlation between ACCD morbidity with air pressure (AP) and relative humidity (h average daily) in summer (3D dispersion diagram: AP (gPa) and h.ep.day, $\%$ and ACCD morbidity (men/day))

Multiple correlation coefficient was $\mathrm{R}_{\text {mult }}=0.59$, multiple determination coefficient was $R_{\text {mult }} 2=0.35$ ( $\left.p=0.004\right)$, therefore, $35 \%$ ACCD cases were determined by a complex negative influence exerted by the above-mentioned factors in summer. As we divided our sampling as per sex, we detected that air pressure was the basic predictor influencing ACCD occurrence frequency in women in summer $(\mathrm{r}=-0.47 ; \mathrm{p}=0.004)$; as for men, relative humidity was the basic predictor in their case $(\mathrm{r}=-0.42 ; \mathrm{p}=0.013)$.
Conclusion. In winter emergency calls frequency related to ACCD grows when average air temperature drops and speed of changes in the Sun radiation flux density increases during a day. We detected a multi-factor dependence between ACCD occurrence frequency and the following predictors: temperature pathogenicity index and speed of changes in the Sun radiation flux density during a day.

In spring frequency of emergency calls related to ACCD correlates positively with temperature pathogenicity index regardless of patients' sex. Air pressure pathogenicity index is an additional predictor for women which determines ACCD morbidity growth.

In summer ACCD morbidity growth is caused by air pressure and relative humidity drops. Women are apparently more sensitive to air pressure fluctuations in terms of summer ACCD morbidity; men, to relative humidity fluctuations.

The obtained data help to plan prophylaxis activities aimed at ACCD prevention for people who are in risk groups allowing for external factors and season specificity.

\section{References}

1. Andronova T.I., Deryapa N.R., Solomatin A.P. Deryapa N.R., Solomatin A.P. Geliometeotropnye reaktsii zdorovogo i bol'nogo cheloveka [Helio- and meteotropic reactions of a healthy person and an ill person]. Leningrad, 1982, 232 p. (in Russian).

2. Boksha V.G., Bogutskii B.V. Meditsinskaya klimatologiya i klimatoterapiya [Medical climatology and climate therapy]. Kiev, 1982, 264 p. (in Russian).

3. Vedenie bol'nykh s ostrym narusheniem mozgovogo krovoobrashcheniya na dogospital'nom etape: Metodicheskie rekomendatsii [Observing patients with acute cerebral circulation disorders at pre-hospitalization stage: Methodical guidelines] In: V.I. Skvortsova, ed. Moscow, 2010, 35 p. (in Russian).

4. Zhuravlev V.M., Mashin V.V., Belova L.A. [i dr.] Vliyanie solnechnoi aktivnosti na risk razvitiya ostrogo narusheniya mozgovogo krovoobrashcheniya [Influence of solar activity on risk of 
development sharp violation of brain blood circulation]. Mezhdunarodnyi zhurnal prikladnykh i fundamental'nykh issledovanii, 2015, no. 2, pp. 38-41 (in Russian).

5. Voronin N.M. Osnovy biologicheskoi i meditsinskoi klimatologii [Basics of biological and medical climatology]. Moscow, Meditsina, Publ., 1981, 352 p. (in Russian).

6. Gurfinkel' Yu.I. Fiziologicheskie i patofiziologicheskie aspekty vliyaniya kosmicheskoi pogody na chelovecheskii organizm [Physiological and pathophysiological aspects of influence exerted by space weather on a human body]. Vliyanie kosmicheskoi pogody na cheloveka $v$ kosmose $i$ na zemle: materialy mezhdunarodnoi konferentsii [Influence exerted by space weather on a man both in space and on the Earth: materials of an international conference]. Moscow, IKIRAN, Publ., 2013, part 2, pp. 560-568 (in Russian).

7. Karelin A.O., Gederim V.V., Sokolovskii V.V., Shapovalov S.N. O vliyanii kosmogeofizicheskikh i meteorologicheskikh faktorov na pokazateli nespetsificheskoi rezistentnosti organizma [The influence of space geophysical and meteorological factors on the parameters of the body's nonspecific resistance]. Gigiena i sanitariya, 2008, no. 1, pp. 29-33 (in Russian).

8. Martirosyan V.V., Dolgusheva Yu.A. Veroyatnostnyi analiz vliyaniya ekzogennykh faktorov na chastotu vozniknoveniya gemorragicheskogo insul'ta $\mathrm{v}$ periody vysokoi i nizkoi solnechnoi aktivnosti [The probabilistic analysis of influence of exogenous risk factors on the frequency of developing of hemorrhagic stroke during the periods of high and low solar activity]. Zhurnal fundamental'noi meditsiny i biologii, 2016, no. 1, pp. 52-59 (in Russian).

9. Pizova N.V., Prozorovskaya S.D., Pizov A.V. Meteorologicheskie faktory riska insul'ta v Tsentral'nom regione Rossii [Weather risk factors for stroke in the Central Region of Russia]. Nevrologiya, neiropsikhiatriya, psikhosomatika, 2012, no. 1, pp. 63-67 (in Russian).

10. Rukovodstvo po skoroi meditsinskoi pomoshchi [Guidance on emergency]. In: A.L. Vertkin, S.F. Bagnenko, eds. Moscow, GEOTAR-Media, Publ., 2006, 820 p. (in Russian).

11. Botoeva N.K., Belyaeva V.A., Khetagurova L.G., Gonobobleva T.N. Sezonnaya dinamika nelineinykh pokazatelei variabel'nosti serdechnogo ritma i GRV-bioelektrogramm u lits, prozhivayushchikh v predgornoi zone Severnoi Osetii [Seasonal dynamics of nonlinear heart rate variability and gdvbioelektrogramm of the north Ossetia foothill area residents]. Vestnik novykh meditsinskikh technologii, 2013, vol. 20, no. 2, pp. 417-422 (in Russian).

12. Cold exposure and winter mortality from ischemic heart disease, cerebrovascular disease, respiratory disease, and all causes in warm and cold regions of Europe. The Eurowinter Group. Lancet, 1997, vol. 349, pp. 1341-1346.

13. Cowperthwaite M.C., Burnett M.G. An analysis of admissions from 155 United States hospitals to determine the influence of weather on stroke incidence. J. Clin. Neurosci., 2011, vol. 18, no. 5, pp. 618-623.

14. Feigin V.L., Parmar P.G., Barker-Collo S. [et al.]. Geomagnetic Storms Can Trigger Stroke. Evidence From 6 Large Population-Based Studies in Europe and Australasia. Stroke, 2014, vol. 45, pp. 1639-1645.

15. Feigin V.L., Wiebers D.O. Environmental factors and stroke. A selective review. $J$. Stroke Cerebrovasc. Dis, 1997, vol. 6, pp. 107-112.

16. Milosevic V., Zivkovic M., Djuric S., Vasic V., Tepavcevic D.K., Bumbasirevic L.B., [et al.] Hospitalizations due to spontaneous intracerebral hemorrhage in the region of Nis (Serbia): 11-year time-series analysis. Clin Neurol Neurosurg, 2011, vol. 113, no. 7, pp. 552-555.

17. Turin T.C., Kita Y., Murakami Y., Rumana N., Sugihara H., Morita Y., [et al.]. Higher stroke incidence in the spring season regardless of conventional risk factors: Takashima Stroke Registry, Japan, 1988-2001. Stroke, 2008, vol. 39, no. 3, pp. 745-752.

18. Frost L., Vukelic Andersen L., Mortensen L.S., Dethlefsen C. Seasonal variation in stroke and stroke-associated mortality in patients with a hospital diagnosis of nonvalvular atri- 
al fibrillation or flutter. A population-based study in Denmark. Neuroepidemiology, 2006, vol. 26, no. 4, pp. 220-225.

19. Charach G., Shochat M., Argov O. [et al.]. Seasonal changes in blood pressure: Cardiac and cerebrovascular morbidity and mortality. World J. Hypertens., 2013, vol. 3, no. 1, pp. 1-8.

20. Wang Y., Levi C.R., Attia J.R., D’Este C.A., Spratt N., Fisher J. Seasonal variation in stroke in the Hunter Region, Australia: A 5-year hospital-based study, 1995-2000. Stroke, 2003, vol. 34, no. 5, pp. 1144-1150.

21. J. Jimenez-Conde, A. Ois, M. Gomis, A. Rodriguez-Campello, E. Cuadrado-Godia, I. Subirana, [et al.]. Weather as a trigger of stroke. Daily meteorological factors and incidence of stroke subtypes. Cerebrovasc Dis, 2008, vol. 26, pp. 348-354.

Belyaeva V.A. Influence exerted by risk factors of space and erath weather on frequency of emergency calls from patients with acute cerebral circulation disorders. Health Risk Analysis, 2017, no. 4, pp. 76-82. DOI: 10.21668/health.risk/2017.4.08.eng

Received: 02.10.2017

Accepted: 20.12.2017

Published:30.12.2017 


\section{HEALTH RISK MANAGEMENT IN OCCUPATIONAL MEDICINE}

UDC 614.2: 613.62

DOI: $10.21668 /$ health.risk/2017.4.09.eng

\section{CONTEMPORARY PROBLEMS OF HEALTH PROTECTION FOR WORKERS EMPLOYED AT A LARGE INDUSTRIAL ENTERPRISE AND WORKING UNDER OCCUPATIONAL HAZARDS}

\section{E.Ya. Titova, S.A. Golub'}

Perm State Medical University named after Academician E.A. Wagner, 26 Petropavlovskaya Str., Perm, 614000, Russian Federation

We examined data provided by a healthcare facility at a large industrial enterprise focusing on occupational morbidity dynamics over 2013-2016 and periodical medical examinations results obtained in 2015 and 2016. We created a specialized program and applied it to conduct sociological research on health of workers who has a periodical medical examination. We detected that most questioned workers (50.48\%) whose occupations were associated with dangerous and hazardous occupational factors were poorly aware of occupational diseases prevention and needed relevant knowledge. It is shown that over 2013-2016 occupational morbidity decreased from 9.38 cases per 10,000 workers to 3.55 cases. However, it remained higher that in Russian and Perm region on average.

All occupational diseases were detected in workers older than 40 with their working record being longer than 15 years. A share of people able to work with certain limitations grew in 2016 in comparison with 2015 (from 7.35 to $9.31 \%$ ); a number of people who needed sanatorium-resort therapy also grew from 19.96 to $32.12 \%$; a number of people with general somatic diseases increased from 31.23 to $70.17 \%$ ); health index reduced from 38.77 to $29.82 \%$. Musculoskeletal system diseases, connective tissue diseases, circulatory system diseases, eye and its accessory apparatus diseases, respiratory organs diseases, and digestive organs diseases prevailed in general somatic morbidity structure. We registered a substantial growth in hearing organs diseases (mostly hearing loss, from 49.47 to 99.06 cases per 100 examined); skin and subcutaneous tissue diseases (from 7.73 to 36.3 cases per 100 examined); urinary system diseases (from 68.42 to 100.62 cases per 100 examined). We detected that most examined workers pursued unhealthy lifestyle. For example, $29.9 \%$ often consumed strong spirits (equally men and women), and $72.8 \%$ smoked. All the respondents tended to have low physical activity. We also revealed some drawbacks in periodical medical examinations procedure: $26.3 \%$ respondents mentioned medical staff were indifferent and even rude to them; $40.8 \%$ complained on having to wait for a long time to get to a specialist; $26.2 \%$ said they had to wait for a reception in rather unfavorable conditions; all the respondents mentioned untimely receipt of their "health passport".

The data we collected can be applied in assessing risks of health disorders occurrence in workers employed at industrial enterprises and in the process of creating prevention activities aimed at health risks minimization.

Key words: large industrial enterprise, occupational morbidity, periodical medical examination, morbidity, morbidity structure, workers' lifestyle, working conditions, medical examinations drawbacks.

A most important social and economic Strategy" which was approved by the RF task fixed in "The RF National security President Order No. $683^{1}$ dated December

(C) Titova E.Ya., Golub' S.A., 2017

Elena Ya. Titova - Associate Professor at Public Health and Healthcare Department, Candidate of Medical Sciences (e-mail: superoziz@yandex.ru; tel: +7 (342) 233-25-31).

Svetlana A. Golub' - Student (e-mail: superoziz@yandex.ru; tel: +7 (342) 233-25-31). 
$31 / 2015$ is to preserve and to improve working population health. Today, as our society is undergoing reforms in many spheres, safe working conditions in industry and workers' health protection are among factors securing economic development of our country [4,5,12-15]. All workers exposed to industrial hazardous factors existing at their workplaces run risks of occupationally-induced pathology evolvement [11].

Occupational risk concept was adopted in Russia and it became a significant stage in labor protection system improvement as it allowed to make activities aimed at workers' health preservation and improvement more prevention-oriented which was especially important for those workers who had to perform their tasks under hazardous conditions [3]. Safe working conditions and low risks of impacts exerted by unfavorable environmental factors on working population are the most important conditions for persistent social and economic development of any state. Prevention of health disorders in workers, first of all, occupational and occupationally induced ones, is among priority tasks occupational medicine has to solve [5].

Personnel health management is seen as a most important technique in economically developed countries; when we apply it, we can cut organizational costs due to decrease in morbidity and labor productivity growth. Countries which are able to do it are the most competitive [16, 17].

The RF Government issued the Order No. 2580-r on December 28, 2012 approving "Medical Science Development
Strategy in the RF up to $2025^{\prime 2}$; this strategy stresses the necessity to "change priorities in planning strategies aimed at population health improvement, namely, to make emphasis not on clinical approaches but on prevention programs". A priority task is to develop a set of activities which can help to prevent hazardous impacts exerted by working conditions on health. "Global Plan of Action on Workers' Health" was approved on the 60th WHO session (May 23, 2007); it contains the following: "workers' health is determined both by risk factors existing at a workplace and by social and individual factors, as well as by a free access to medical and sanitary service" [2].

As per data taken from official statistics contained in Rospotrebnadzor state reports, occupational morbidity in the RF still remains high despite a slight decrease which was detected in the parameter in 2016 against 2015, being equal to 1.47 cases per 10,000 workers (it was 1.76 cases in 2013; in 2014, 1.74 cases; in 2015, 1.65 случаев) [8-10]. Occupational morbidity in Perm region annually is higher than the average country level: 1.83 cases in 2013; 1.86 , in $2014 ; 1.37$, in $2015 ; 1.2$ cases per 10,000 workers in 2016 [6,7].

Our research goal was to examine certain contemporary problems related to health protection of workers employed at a large industrial enterprise.

Data and methods. We studied data on occupational morbidity taken from reports collected in 2013-2016 by a health station at a large industrial enterprise and

\footnotetext{
${ }^{1}$ On the Russian Federation National Security Strategy: The RF President Order dated December 31,2015 No. 683. ConsultantPlus. Available at: http://www.consultant.ru/document/cons_doc_LAW_191669/ (10.08. 2017)

${ }^{2}$ Medical Science Development Strategy in the RF up to 2025 / approved by the RF Government Order on December 28, 2012 No. 2580-r. Available at: https://www.rosminzdrav.ru/documents/5413-rasporyazheniepravitelstva-rossiyskoy-federatsii-ot-28-dekabrya-2012-g-n-2580-r (10.08. 2017)
} 
compared them with average country parameters and Perm region parameters. We also compared results of workers' medical examinations performed in 2015 and 2016. We found out how aware workers were on occupational hazards and occupational diseases prevention; to do that, we applied a specially designed sociological research program which also allowed us to analyze respondents' lifestyle and to examine their opinions on periodical medical examinations. We calculated relative and average values, assessed their validity, and determined dynamic series parameters (average chronological value and growth rate). When assessing validity of discrepancies in relative and average values, we applied Student's t-criterion.

Our research was performed at a large industrial enterprise; about 3,000 workers were employed at it. Basic hazard occupational factors there were noise, chemicals, labor hardness, increased air temperature, vibration, and ionizing radiation. According to the Order issued by the RF Labor Ministry on January 24, 2014 No. 33n "On approving a specialized working conditions assessment procedure" ${ }^{3}$, most working places at an enterprise correspond to 3.3 or 3.4 danger category as per working conditions existing at them.

Results and discussion. Our research revealed that 5,000 occupational diseases were registered at the examined enterprise in 2013-2016. Average working period for workers with a diagnosed occupational diseases was equal to $16.2 \pm 0.9$ years, their average age was $43.8 \pm 1.1$. In 20161 occupational disease case, namely chronic toxic bronchitis, was detected, just like in 2015.
Primary occupational morbidity frequency dropped by $62.15 \%$ in 2016 in comparison with 2013 and amounted to 3.55 cases per 10,000 workers. Average chronic diseases values in 2013-2016 amounted to $1.66 \pm 0.14$ cases per 10,000 workers in Russia; $1.57 \pm 0.16$ cases per 10,000 workers in Perm region; $4.14 \pm 1.95$ cases per 10,000 workers at the examined enterprise (Figure 1).

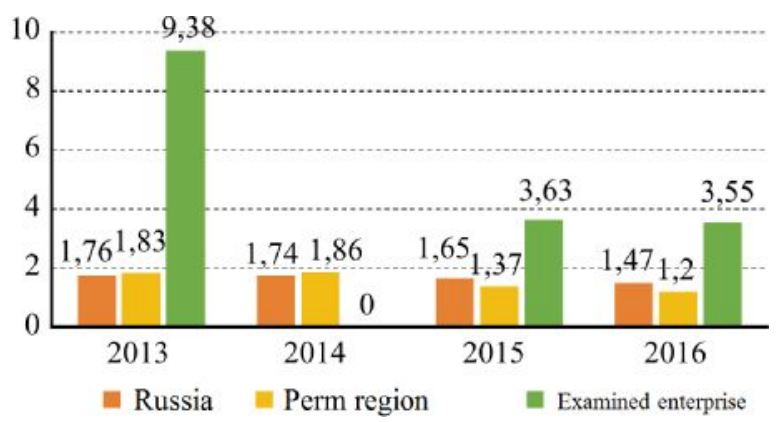

Figure 1. Occupational morbidity dynamics for workers employed at the examined enterprise, in Perm region, and in Russia (per 10,000 workers).

Table 1

Results of workers' periodical medical examinations

\begin{tabular}{|l|c|c|}
\hline \multicolumn{1}{|c|}{ Parameters } & 2015 & 2016 \\
\hline $\begin{array}{l}\text { A share of those who attended } \\
\text { PME from the overall number of } \\
\text { workers who had to attend it, \% }\end{array}$ & 99,30 & 99,10 \\
\hline $\begin{array}{l}\text { A share of people who needed ad- } \\
\text { ditional examinations (health report } \\
\text { not given) \% }\end{array}$ & 7,35 & 9,31 \\
\hline $\begin{array}{l}\text { A share of workers fit for work } \\
\text { with certain limitations, \% }\end{array}$ & 4,20 & 5,18 \\
\hline $\begin{array}{l}\text { A share of workers without any } \\
\text { medical contraindications for } \\
\text { work, \% }\end{array}$ & 88,51 & 84,75 \\
\hline $\begin{array}{l}\text { A share of workers who needed } \\
\text { sanatorium-resort treatment, \% }\end{array}$ & 19,96 & 32,12 \\
\hline $\begin{array}{l}\text { A share of workers with general } \\
\text { somatic diseases, \% }\end{array}$ & 61,23 & 70,17 \\
\hline "Health index", \% & 38,77 & 29,82 \\
\hline
\end{tabular}

\footnotetext{
${ }^{3}$ On approving a specialized working conditions assessment, Classifier of hazardous and (or) dangerous occupational factors, a reporting form for specialized working conditions assessment and an instruction on how to fill it in correctly": The Order by the RF Labor Ministry issued on January 24, 2014 No. 33n (edited on November 14, 2016). ConsultantPlus. Available at: http://www.consultant.ru/document/cons_doc_LAW_158398/ (08.08.2017).
} 
Analysis of periodical medical examinations (PME) results revealed that parameters deteriorated in 2016 in comparison with 2015 (Table 1):

- a share of workers without any medical contraindications for work decreased from $88.51 \%$ to $84.75 \%$, and a share of those fit for work only with limitations increased from $4.2 \%$ to $5.18 \%$;

- a share of workers who needed additional examinations increased from $7.35 \%$ to $9.31 \%$; and a share of those who needed sanatorium-resort treatment, from $19.96 \%$ to $32.12 \%$;

- a share of worker who had general somatic diseases grew from $61.23 \%$ to $70.17 \%$;

- health index fell from $38.77 \%$ to $29.82 \%$.

As per medical examinations data, morbidity frequency grew from $1,178.58$ cases to $1,564.3$ cases per 100 examined workers in 2016 (by $32.73 \%$, the difference is statistically authentic, $\mathrm{p} \leq 0.05)$. Morbidity grew practically as per each nosologic category: skin and subcutaneous tissue diseases grew by $369.6 \%$; ear and mastoid diseases, by $100.24 \%$; blood and blood making organs diseases, by $48.43 \%$; musculoskeletal system diseases, by $41.71 \%$; eye and its accessory apparatus diseases, by $34.68 \%$; neoplasms, by $33.33 \%$; circulatory system diseases, by $31.65 \%$; endocrine system diseases, nutrition disorders and metabolism disorders, by 5.84\% (Figure 2).

The same 5 nosologies prevailed in morbidity structure in 2015, as it was in 2015. Their share was equal to $77.37 \%$ in 2016 and to $73.98 \%$ in 2015. However, their ranking changed a bit.

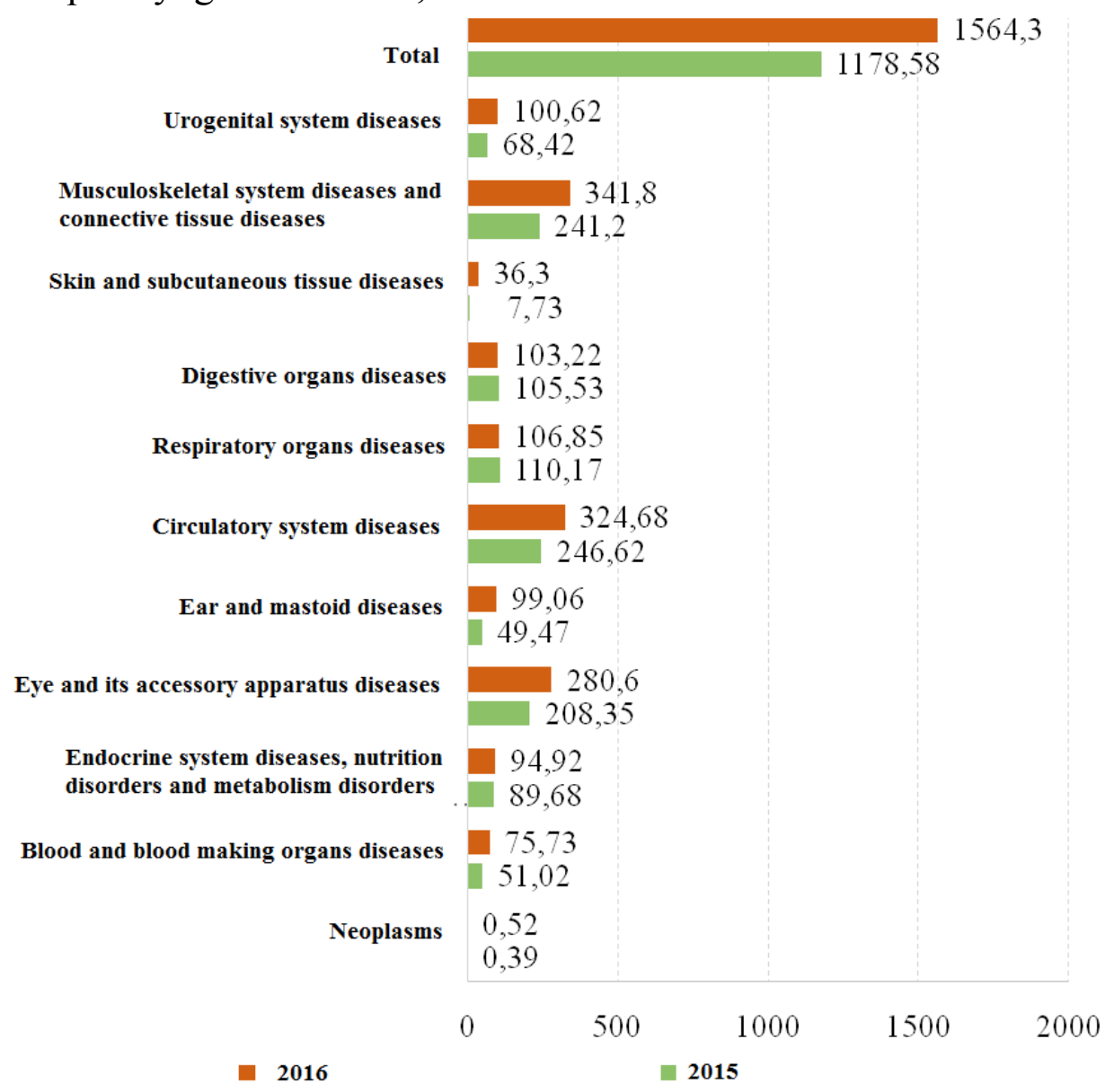

Figure 2. Morbidity frequency as per medical examinations data (per 100 examined) 
Thus, musculoskeletal system diseases and connective tissue diseases took the first place in $2016(21.85 \%)$, but this place belonged to circulatory system diseases in 2015 (20.92\%). Circulatory system diseases took the second place in $2016(20.76 \%)$, but in 2015 it belonged to musculoskeletal system diseases and connective tissue diseases $(20.47 \%)$. Eye and its accessory apparatus diseases held the third place both in 2016 and 2015 (17.94\% and 17.68\% correspondingly). The fourth place belonged to respiratory organs diseases $(6.83 \%$ and 9.35\% correspondingly). Digestive organs diseases took the fifth place both in 2015 and $2016(6.6 \%$ and $8.95 \%$ correspondingly) (Table 2).

Table 2

Morbidity structure as per medical examinations data in 2015 and $2016(\%)$

\begin{tabular}{|l|c|c|}
\hline \multicolumn{1}{|c|}{ Parameter } & 2015 & 2016 \\
\hline Neoplasms & 0,03 & 0,03 \\
\hline $\begin{array}{l}\text { Blood and blood making organs } \\
\text { diseases }\end{array}$ & 4,33 & 4,84 \\
\hline $\begin{array}{l}\text { Endocrine system diseases, nutri- } \\
\text { tion disorders and metabolism dis- } \\
\text { orders }\end{array}$ & 7,61 & 6,07 \\
\hline $\begin{array}{l}\text { Eye and its accessory apparatus dis- } \\
\text { eases }\end{array}$ & 17,68 & 17,94 \\
\hline $\begin{array}{l}\text { Ear and mastoid diseases (including } \\
\text { hearing loss) }\end{array}$ & 4,20 & 6,33 \\
\hline Circulatory system diseases & 20,92 & 20,76 \\
\hline Respiratory organs diseases & 9,35 & 6,83 \\
\hline Digestive organs diseases & 8,95 & 6,60 \\
\hline $\begin{array}{l}\text { Skin and subcutaneous tissue dis- } \\
\text { eases }\end{array}$ & 0,66 & 2,32 \\
\hline $\begin{array}{l}\text { Musculoskeletal system and con- } \\
\text { nective tissue diseases }\end{array}$ & 20,47 & 21,85 \\
\hline Urogenital system diseases & 5,81 & 6,43 \\
\hline Total morbidity & $\mathbf{1 0 0 , 0 0}$ & $\mathbf{1 0 0 , 0 0}$ \\
\hline
\end{tabular}

Sociological research performed on workers who attended a medical examination revealed that most respondents were $30-49$ years old $(46.6 \%)$ and $50-59$ years old (38.8\%); only $6.8 \%$ were 60 and older. Most respondents worked at the examined enterprise for a long time: $35.9 \%$ for 11 years and longer; $30.1 \%$, 6-10 years; $23,3 \%$, 4-5 years; only $1.0 \%$ respondents worked there less than 1 year. $87.3 \%$ respondents had secondary vocational education, $6.8 \%$ had higher education. $41.7 \%$ respondents were females, and $58.3 \%$ males.

We detected that $50.5 \%$ were poorly aware of hazardous occupational factors existing at their enterprise and of their influence on workers' health as well as of occupational diseases prevention; but they were eager to get this knowledge.

Nicotine addiction prevailed among workers as $72.8 \%$ of them smoked: $85.0 \%$ men and $56.0 \%$ women. Smoking prevalence among workers employed at various industrial enterprises in Perm region was also detected by other researchers [5]; they give data on a share of smoking workers varying from 56 to $78 \%$. And here there are no authentic discrepancies between men and women $(p \geq 0.05)$. We detected that $29.9 \%$ respondents drank strong spirits several times a month and even more often (discrepancies in alcohol intake between men and women are also statistically insignificant, $\mathrm{p} \geq 0.05$ ). These results are well in line with data obtained at other regional industrial enterprises [1]. And we should note here that, in spite of rather high prevalence of bad habits among workers, only half of respondents try to abandon them. All the respondents $(100 \%)$ told they had very little physical activity. All the above-mentioned exerts negative influence on workers' health.

Most respondents gave positive assessment of medical personnel work during medical examinations (73.79\%); however, $25.24 \%$ complained on indifferent attitudes towards a patient, and $0.97 \%$ told medical personnel were even rude to them. Time spent in waiting for a doctor's reception was mostly from 10 to 30 minutes as 
$59.22 \%$ mentioned exactly this waiting period; $34.954 \%$ said they had to wait for 31 60 minutes; $5.83 \%$ waited for more than 1 hour. $26.2 \%$ respondents complained on bad conditions in which they had to wait for a doctor's reception.

Besides, respondents were offered to assess certain criteria as per 5-score scale; these criteria characterized a medical examination quality (Table 3 ).

\section{Table 3}

Medical examinations quality assessment as per 5-score scale

\begin{tabular}{|l|c|}
\hline \multicolumn{1}{|c|}{ Criterion } & Average score \\
\hline $\begin{array}{l}\text { The main purpose of a medical exam- } \\
\text { ination is achieved - occupational } \\
\text { and chronic diseases prevention }\end{array}$ & 4,12 \\
\hline $\begin{array}{l}\text { Medical recommendations are given } \\
\text { after an examination }\end{array}$ & 4,15 \\
\hline $\begin{array}{l}\text { "Health report" is received on time } \\
\text { (during 30 days) }\end{array}$ & 2,4 \\
\hline
\end{tabular}

Rather low scores given to a timely receipt of a health report can be explained by a situation when workers have their tests and EEG taken exactly on a day when a medical examination takes place. As there are a lot of workers who have to attend it, research results are often received with a delay.

\section{Conclusions:}

1. Workers employed at the examined enterprise are influenced by dangerous and adverse occupational factors and it exerts negative impacts on their health. Most workplaces belong to 3.3 or 3.4 danger category. But most questioned workers $(50.48 \%)$ are poorly aware of occupational diseases prevention and need this knowledge.

2. In 2013-2016 a decrease in occupational morbidity was observed (from 9.38 to 3.55 per 10,000 workers); however, it still remains significantly higher than in the country or Perm region on average. All the detected occupational diseases during the examined period occurred in workers who worked for more than 15 years at the examined enterprise and was older than 40 .

3. As per medical examinations results obtained in 2016, we detected that a share of workers who were fit for work with certain limitations grew in comparison with 2015 (from 7.35\% to 9.31\%); a share of workers who needed sanatoriumresort treatment also grew (from 19.96\% to $32.12 \%$ ); a share of workers with general somatic diseases grew from $61.23 \%$ to $70.1 \%$ ); overall health index fell from $38.77 \%$ to $29.82 \%$ ).

4. As per medical examinations data, the same nosologic forms prevailed in the overall morbidity structure both in 2015 and 2016: musculoskeletal system and connective tissue diseases; circulatory system diseases; eye and its accessory apparatus diseases; respiratory organs diseases; digestive organs diseases. Their share is equal to $77.37 \%$ and $73.98 \%$ correspondingly. It is interesting to note a considerable frequency growth in such nosologic categories as ear and mastoid diseases represented by hearing loss (from 49.47 to 99.cases per 100 examined), skin and subcutaneous tissue diseases (from 7.73 to 36.3 cases per 100 examined), and urogenital system diseases (from 68.42 to 100.62 cases per 100 examined).

5. A great number of respondents pursue unhealthy life style: $72.8 \%$ of them smoke; $29.9 \%$, equally men and women, drink strong spirits; all the respondents tend to have insignificant physical activity.

6. There are some drawbacks in periodical medical examinations procedure: $26.3 \%$ respondents complained medical personnel were indifferent and even rude to them; $40.8 \%$ mentioned they had to wait for a doctor's receipt for a long time; 
$26.2 \%$ said they had to wait for a receipt in bad conditions; all the respondents said they didn't receive their health report on time.
The data we obtained can be applied in assessing health risks for workers employed at an enterprise and for developing prevention measures aimed at their minimization.

\section{References}

1. Barg A.O., Lebedeva-Nesevrya N.A. Risk-kommunikatsiya v sisteme analiza professional'nykh riskov zdorov'yu rabotnikov promyshlennogo predpriyatiya [Risk communication in analysis of occupational health risk for industrial workers]. Meditsinatruda i promyshlennayaekologiya, 2015, no. 8, pp. 28-33 (in Russian).

2. Zdorov'e rabotayushchikh: global'nyi plan deistvii (2008-2017 g.). Prinyat shestidesyatoi sessiei Vsemirnoi assamblei zdravookhraneniya 23.05.2007 g. [Workers' health: global plan of action (2008-2017.). Approved at the 60th session of the WHO on May 23, 2007]. Vsemirnaya organizatsiya zdravookhraneniya, Zheneva, 2007, pp.1-12. Available at: http://www.who.int/occupational_health/WHO_health_assembly_ru_web.pdf (03.09.2017) (in Russian).

3. Izmerov N.F. Aktualizatsiyavoprosovprofessional'noizabolevaemosti [Actualization of occupational morbidity issues]. Zdravookhranenie Rossiiskoi Federatsii, 2013, no.2, pp.14-17 (in Russian).

4. Izmerov N.F., Bukhtiyarov I.V., Prokopenko L.V. Voprosy professional'noi zabolevaemosti: retrospektiva i sovremennost' [Occupational morbidity issues: retrospect and contemporary situation]. Professiya i zdorov'e: Materialy XI Vserossiiskogo kongressa, Moskva, 27-29 noyabrya 2012 g. [Occupation and health: Materials of the XI Russian Congress, Moscow, November 27-29, 2012]. Moscow, FGBU «NII MT»RAMN, Publ., 2012, pp. 29-36 (in Russian).

5. MR 2.1.10.0033-11. Otsenka riska, svyazannogo s vozdeistviem faktorov obraza zhizni na zdorov'e naseleniya: Metodicheskie rekomendatsii / utv. Rospotrebnadzorom 31.07.2011 [Risk assessment related to the impact of lifestyle factors on human health: Methodical guidelines / approved by Rospotrebnadzor on July 31, 2011]. Available at: http://docs.cntd.ru/document/1200111974 (03.09.2017) (in Russian).

6. O sostoyaniisanitarno-epidemiologicheskogoblagopoluchiyanaseleniya v Permskom krae v 2015 godu: Gosudarstvennyi doklad [On sanitary-epidemiologic welfare of the population in Perm region in 2015: State report].Perm, Federal'naya sluzhba po nadzoru v sfere zashchity prav potrebitelei i blagopoluchiya cheloveka, Publ., 2016, 269 p. Available at: http://59.rospotrebnadzor.ru/c/document_library/get file?uuid=2e1fb575-f452-4f66-afee3255ed6e019c\&groupId=10156 (03.09.2017) (in Russian).

7. O sostoyanii sanitarno-epidemiologicheskogo blagopoluchiya naseleniya $\mathrm{v}$ Permskom krae v 2016 godu: Gosudarstvennyi doklad [On sanitary-epidemiologic welfare of the population in Perm region in 2016: State report]. Perm, Federal'naya sluzhba po nadzoru v sfere zashchity prav potrebitelei i blagopoluchiya cheloveka, Publ., 2017, 266 p. Available at: http://59.rospotrebnadzor.ru/c/document library/get file?uuid=1eb7862f-cd8a-4d9e-87dee687570fd5b8\&groupId=10156 (03.09.2017) (in Russian).

8. O sostoyanii sanitarno-epidemiologicheskogo blagopoluchiya naseleniya v Rossiiskoi Federatsii v 2015 godu: Gosudarstvennyi doklad [On sanitary-epidemiologic welfare of the population in the Russian Federation in 2015: State report]. Moscow, Federal'naya sluzhba po nadzoru v sfere zashchity prav potrebitelei i blagopoluchiya cheloveka, Publ., 2016, 200 p. Available at: http://docplayer.ru/28344531-Gosudarstvennyy-doklad-o-sostoyanii-sanitarno-epidemiologicheskogo-blagopoluchiya-naseleniya-v-rossiyskoy-federacii-v-2015-godu.html (03.09.2017) (in Russian). 
9. O sostoyanii sanitarno-epidemiologicheskogo blagopoluchiya naseleniya v Rossiiskoi Federatsii v 2016 godu: Gosudarstvennyi doklad [On sanitary-epidemiologic welfare of the population in the Russian Federation in 2016: State report]. Moscow, Federal'naya sluzhba po nadzoru v sfere zashchity prav potrebitelei i blagopoluchiya cheloveka, Publ., 2017, 216 p. Available at: http://rospotrebnadzor.ru/upload/iblock/0b3/gosudarstvennyy-doklad-2016.pdf (03.09.2017) (in Russian).

10. Onishchenko G.G. Sostoyanie uslovii truda i professional'naya zabolevaemost' rabotnikov $\mathrm{v}$ Rossiiskoi Federatsii [Working conditions and occupational morbidity in workers of the Russian Federation]. Gigiena i sanitariya, 2009, no. 3, pp. 66-70 (in Russian).

11. Professional'naya patologiya. Natsional'noe rukovodstvo [Occupational pathology. National guide]. In: N.F. Izmerov, ed. Moscow, GEOTAR-Media, Publ., 2012, 27 p. (in Russian).

12. Rakhmanin Yu.A., Sinitsyna O.O. Sostoyanie i aktualizatsiya zadach po sovershenstvovaniyu nauchno-metodologicheskikh i normativno-pravovykh osnov v oblasti ekologii cheloveka i gigieny okruzhayushchei sredy [Status and actualization of tasks to improve the scientific-methodological and regulatory frameworks in the field of human ecology and environmental hygiene]. Materialy Plenuma nauchnogo soveta po ekologii cheloveka i okruzhayushchei sredy Rossiiskoi Federatsii, Moskva, 1314 dekabrya $2012 \mathrm{~g}$. [Materials of the Scientific council plenary meeting on human ecology and environment in the Russian Federation, Moscow, December 13-14,2012]. Moscow, 2012, pp. 3-7 (in Russian).

13. Titov A.A., Titova E.Ya. O perspektivnykh napravleniyakh zheleznodorozhnoi meditsiny [Railway medicine prospects]. Problemy ekonomiki, organizatsii $i$ upravleniya $v$ Rossii $i$ mire: Materialy XY mezhdunarodnoi nauchno-prakticheskoi konferentsii [Issues of economics, organization and management in Russian and worldwide: Materials of the XY international theory and practical conference].Praga, 2017, pp. 65-68 (in Russian).

14. Titova E.Ya., Konovalova N.V. O nekotorykh aspektakh upravleniya zdorov'em personala [On certain aspects of managing personnel health]. Problemy ekonomiki, organizatsii i upravleniya $v$ Rossii i mire: Materialy YI mezhdunarodnoi nauchno-prakticheskoi konferentsii [Issues of economics, organization and management in Russian and worldwide: Materials of the YI international theory and practical conference]. Praga, 2014, pp. 224-225 (in Russian).

15. Khrupachev A.G., Khadartsev A.A., Kashintseva L.V., Sedova O.A Ekonomicheskie aspekty okhrany truda na osnove kolichestvennoi otsenki professional'nogo riska [Economic aspects of labor protection based on quantitative assessment of occupational risk]. Regional'naya ekonomika: teoriya i praktika, 2011, no. 19 (202), pp. 22-28 (in Russian).

16. Quality of the working environment and productivity: Research findings and case studies.Luxembourg, European Agency for Safety and Health at Work, 2004, 82 p. Available at: https://www.google.ru/url?sa=

t\&rct=j\&q=\&esrc $=$ s\&source=web\&cd=1\&ved=0ahUKEwjrq4_e24PYAhXEBZoKHajFBXM QFggoMAA\&url=

http\%3A\%2F\%2Fciteseerx.ist.psu.edu\%2Fviewdoc\%2Fdownload\%3Fdoi\%3D10.1.1.114.6196 \%26rep\%3Drep1\%26type\%3Dpdf\&usg=AOvVaw25cSJMKr2aqE4Xikt-1SOB (10.09.2017).

17. The Global Competitiveness Report 2010-2011. Geneva, World Economic Forum, $2010,516 \mathrm{p}$.

Titova E.Ya., Golub' S.A. Contemporary problems of health protection for workers employed at a large industrial enterprise and working under occupational hazards. Health Risk Analysis, 2017, no. 4, pp. 83-90. DOI: 10.21668/health.risk/2017.4.09.eng

Received: 12.09 .2017

Accepted: 22.12.2017

Published: 30.12.2017 
UDC 616.314-002: 613: 646

DOI: $10.21668 /$ health.risk/2017.4.10.eng

\section{FACTORS CAUSING RISKS OF CARIES EVOLVEMENT IN DENTAL SOLID TISSUES UNDER ACCLIMATIZATION}

\section{R.S. Rakhmanov, M.Kh. Alikberov, Z.A. Omarova}

Nizhegorodskiy Scientific Research Institute for Hygiene and Occupational Pathology, 20 Semashko Str., Nizhniy Novgorod, 603950, Russian Federation

We analyzed parameters characterizing mineral balance in a body and dental state in two groups of healthy men ( $n=15$ in each, aged $34.7 \pm 0.6)$ in hot and humid marine climate conditions; one group was made of people undergoing acclimatization, the second one consisted of local population.

We assessed working conditions and their category, and metrological data with determining environmental thermal load (ETL-index).

Both groups worked outdoors; their labor had IIb category; they had to work overtime and under increased psychoemotional loads; their working conditions differed as per nutrition and accommodation. When people from both groups had to work beyond their permanent location, their nutrition was represented by individual rations.

Labor hardness was assessed as 3.2; labor intensity, as 3.2. Daytime temperature reached $30,0{ }^{\circ} \mathrm{C}$, relative air humidity was $77.3 \pm 2.6 \%$, wind speed was $4.3 \pm 0.3 \mathrm{~m} / \mathrm{sec}$. Microclimate was assessed as having 3.1 hazard category. Overall, working conditions were assessed as hazardous (3.3 hazard category).

Electrolyte balance in a body was violated and it was proved by ower contents of $\mathrm{K}$, $\mathrm{Na}$, and $\mathrm{Cl}$ in blood serum; it was more apparent in people who were undergoing acclimatization. $70.0 \%$ of local people had Ca contents in blood serum lower than the physiological standard. Lower Ca and increased P contents in blood serum were also detected in those undergoing acclimatization which could be evidence that Ca was washed out of a body and greater risk of dental caries occurred. As per observation dynamics we detected the following processes in people undergoing acclimatization: $p H$ saliva and its mineralizing function shifting to acidity, salivation rate, and lower enamel resistance; they proved there was a growth in dental solid tissues demineralization. These parameters corresponded to those detected in local population. It calls for primary prevention activities aimed at fighting caries of dental solid tissues.

Key words: hot and humid marine climate, acclimatization, minerals, dental state, blood serum, risk, dental caries.

World practice has proved that prevention programs implementation leads to a drastic decrease in caries and teeth losses; prevention techniques are 20 times cheaper than treatment of already existing dental diseases $[5,19]$. Over the last three decades prevention programs implementation has resulted in decrease in caries prevalence in many regions all over the world and in all age groups. However, this trend hasn't occurred in all the social groups to the same extent: the disease risk turned out to be higher among population with low social-economic status (a substantial

(C) Rakhmanov R.S., Alikberov M.Kh., Omarova Z.A., 2017

Rofail' S. Rakhmanov - Doctor of Medical Sciences, Professor, Director (e-mail: raf53@mail.ru; tel.: +7 (831) 419-61-94).

Murat Kh. Alikberov - Junior Researcher at Laboratory for Assessing Actual Nutrition of Working Population (e-mail: recept@nniigp.ru; tel.: +7 (831) 419-61-94).

Zul'mira A. Omarova - A physician at Clinical-Diagnostic Laboratory (e-mail: recept@nniigp.ru; tel.: +7 (831) 419-61-94). 
growth was observed from 1990 to 2013) $[9,12,16-18]$.

One of the most important concepts underlying caries prevention is a fact that the carious process is simultaneously dynamic and reversible $[11,14]$. It happens due to demineralization and remineralization. Demineralization occurs when dental deposit acids on a tooth surface wash $\mathrm{Ca}$ ions and phosphate-ions out of enamel hydroxyapatites and it results in mineral substances losses out of teeth tissues. Remineralization occurs when acid effects are removed and free $\mathrm{Ca}$ and phosphate ions which are present in the saliva penetrate demineralized enamel areas and the mineral component in them grows.

Teeth caries has a multi-factor nature $[7,12]$. Interaction between the dental deposit, ration components and teeth tissues, as well as genetic and ecological factors, make the greatest contribution into teeth caries pathogenesis $[8,15,16]$. Other caries-inducing factors are the salivation quality and quantity, overall health, and extreme impacts on a body. The saliva, chronic systemic diseases, and weak immunity are thought to be basic internal factor which can cause caries evolvement [3, $6,10,11]$. Therefore, search for risk factors which can cause teeth tissues demineralization is an urgent theoretical and practical task $[2,11,19]$.

Our research goal was to assess risks of caries evolvement in teeth solid tissues among adult working population under acclimatization in a hot humid sea climate.

Our research tasks were:

1. To assess working conditions for adult men performing their work tasks dur- ing summer.

2. To assess dental state and mineral saturation of a body among local population.

3. To examine risks of caries evolvement in teeth solid tissues under acclimatization in a hot humid sea climate.

Data and methods. The examined region belonged to the IV climatic type in the I zone $^{1}$.

Our research objects were 2 groups of healthy males aged from 30 to 40 (34.7 \pm 0.6$)$. People from the first group resided permanently in the Central Russian regions ( $\mathrm{n}=15$ people); the second group was made up of local population $(\mathrm{n}=15)$. All the people took part in our research quite voluntarily (they gave their informative consent). Work category and working conditions were assessed as per their hazard degree and danger ${ }^{1}$.

Males from the first group were sent to the examined region to perform their work tasks. They were observed starting from the third acclimatization day in the hottest time of the year, in July.

Health risk, including that of caries evolvement, was determined as per dental state data: enamel resistance to effects exerted by a standard acid solution (ER-test), saliva $\mathrm{pH}$ determination, salivation rate, and saliva mineralizing potential [1], as well as per impacts exerted on mineral metabolism parameters in a body: determination of mineral substances $(\mathrm{Na}, \mathrm{K}, \mathrm{Ca}, \mathrm{P}$, $\mathrm{Mn}$, and $\mathrm{Cl}$ ) concentrations in blood serum [4]. Dental state was examined and blood tests taken twice, at the same moment of time, on an empty stomach, initially, and 20 days after.

${ }^{1}$ SER 2.2.4.3359-16. Sanitary-epidemiologic requirement to physical factors at workplaces / approved by the Order signed by the RF Chief Sanitary Inspector on June 21, 2016 года о. 81. Available at: http://docs.cntd.ru/document/420362948 (20.08.2017). 
We assessed the following meteorological data: ambient temperature (average, minimum, and maximum), air speed and air relative humidity. We also determined environment thermal load index, or ETLindex ${ }^{1}$.

The results were statistically treated with AtteStat software. Validity of discrepancy for independent samplings was determined as per Mann-Whitney

Results and discussion. Working conditions both group had to work in didn't have any discrepancies and belonged to 2.2 hazard category. Work tasks were performed outdoors, working hours were irregular, and there was high psychoemotional stress. Out-of-town workers, as opposed to local population, were staying at a hostel and received their meals at a catering facility. If any work tasks were to be performed outside the permanent deployment territories, people from both groups had individual meals.

Labor hardness was assessed as 3.2 hazard degree, labor intensity, as 3.2 hazard degree. Average daily outdoor temperature reached $27.40 \mathrm{C}$ on several days, and maximum one reached 30.00C. Relative air humidity was beyond standard $(77.3 \pm 2.6 \%)$, sometimes reaching $80.0 \%$ $100.0 \%$. Minimum wind speed amounted to $2.0 \mathrm{~m} / \mathrm{sec}$, maximum one, to $7,0 \mathrm{~m} / \mathrm{sec}$ $(4.3 \pm 0.3 \mathrm{~m} / \mathrm{sec})$. Microclimate as per ETLindex was assessed as 3.1 hazard degree. The final estimation was that working conditions were hazardous (3.3 hazard degree).

Assessment of mineral substances concentration in blood serum in both groups revealed that people who came to work in a hot humid sea climate had mineral substances in their blood serum in concentrations within reference limits. However, on the $23 \mathrm{rd}$ acclimatization day, we determined an authentic decrease in $\mathrm{K}$ and $\mathrm{Na}$ concentrations: on average, by $11.2 \%(p=0.0038)$ and by $5.0 \%(p=0.003)$ correspondingly in all the examined people. And here $\mathrm{Na}$ concentration was lower than the standard. $\mathrm{Cl}$ concentration decreased in $80.0 \%$ people, by $2.2 \%$ $(p=0.0028)$ on average. As per individual parameters, $46.7 \%$ had $\mathrm{K}$ concentrations lower than the standard, and $13.3 \%, \mathrm{Cl} ; \mathrm{Na}$ concentration was lower than the standard in all the examined people. It proved there was a disorder in a body electrolyte balance. Ca concentration didn't change authentically $(p=0.106)$; however, it fell in $53.3 \%$ of the examined people. Initially, it was lower than the standard in $53.3 \%$, and by the end of the ob-servations, in $66.7 \%$. $\mathrm{P}$ concentration, on the contrary, grew within the reference limits $(p=0.0104)$, which was detected in $86.7 \%$. It resulted in changes in $\mathrm{Ca}: \mathrm{P}$ ratio: initially, it was equal to 2.29 units; by the end of the observations, to 1.76 units. Only Mn concentration was within the same limits (0.95 against $0.92 \mu \mathrm{mol} / 1, \mathrm{p}=0.22$ ) (Table 1).

Table 1

Mineral substances concentrations un blood serum of people from both groups $(M \pm m)$

\begin{tabular}{|c|c|c|c|}
\hline \multirow{2}{*}{$\begin{array}{c}\text { Substance }(\mathrm{mol} / \mathrm{l}) \text {, } \\
\text { Reference limits }\end{array}$} & \multicolumn{2}{|c|}{ Examined groups } & \multirow[b]{2}{*}{$p$} \\
\hline & $\begin{array}{c}\text { Local } \\
\text { popula-tion }\end{array}$ & $\begin{array}{c}\text { Group 1 } \\
\text { (23-rd day) }\end{array}$ & \\
\hline $\mathrm{K}, 3,5-5,1$ & $4,04 \pm 0,08$ & $3,56 \pm 0,15$ & 0,0186 \\
\hline $\mathrm{Na}, 136-146$ & $\begin{array}{c}135,45 \pm \\
0,58\end{array}$ & $\begin{array}{c}128,5 \pm \\
1,33\end{array}$ & 0,0001 \\
\hline $\mathrm{Cl}, 97-107$ & $\begin{array}{c}104,26 \pm \\
1,04\end{array}$ & $\begin{array}{c}100,0 \pm \\
1,17\end{array}$ & 0,0137 \\
\hline $\mathrm{Ca}, 2,15-2,57$ & $2,12 \pm 0,02$ & $2,04 \pm 0,06$ & 0,076 \\
\hline $\mathrm{P}, 0,87-1,45$ & $0,93 \pm 0,03$ & $1,16 \pm 0,08$ & 0,0044 \\
\hline Mn, $0,80-1,00$ & $0,88 \pm 0,05$ & $0,95 \pm 0,05$ & 0,153 \\
\hline
\end{tabular}

All the assessed parameters, Ca excluded, were within the reference limits in local population. However, $40.0 \%$ had $\mathrm{Na}$ concentration lower than the standard; $6.7 \%, \mathrm{~K}$ and $\mathrm{P}$ concentrations; 26.7\%, Mn 
concentrations. Insufficient $\mathrm{K}$ concentrations parameters were the most significant: they were lower than the reference limits in $70.0 \%$ of the examined people which determined average value in the whole group.

Thermal load resulted in $\mathrm{K}$ concentrations (by 11.9\%), $\mathrm{Na}$ concentrations (by $5.1 \%$ ), and $\mathrm{Cl}$ concentrations (by $4.1 \%$ ) being authentically lower in people under acclimatization than in local population, and $\mathrm{P}$ concentration in them was by $24.7 \%$ higher. $\mathrm{Ca}$ and $\mathrm{Mn}$ concentrations didn't have any discrepancies.

We assessed dental state under acclimatization and revealed that saliva $\mathrm{pH}$ was shifting towards acidity with a $8.1 \%$ decrease $(p=0.0022)$ up to $6.66 \pm 0.08$ units. And changes in saliva $\mathrm{pH}$ were detected in $86.7 \%$ of the examined people. $\mathrm{pH}$ was lower than 6.5 units (average standard value), namely 6.2 units, in $20.0 \%$ of them [1]. Saliva $\mathrm{pH}$ in local population didn't have any authentic discrepancies with the same parameter in group 1 as also $20.0 \%$ had it lower than the average standard value (table 2).

Saliva mineralizing potential (SMP) also decreased authentically by $7.1 \%$ $(p=0.0014)$ to $2.6 \pm 0.18$ scores. Initially, it was estimated as satisfactory; by the end of the observations, it was estimated as low in $40.0 \%$ of the examined people. $26.7 \%$ of the local inhabitants had low SMP, and $6.7 \%$, high SMP. Average SMP values in both groups didn't have any authentic discrepancies.

Salivation rate also decreased authentically, by $5.5 \% \quad(p=0.007)$ to $23.92 \pm 1.36$ $\mathrm{ml} /$ hour. It was detected in $86.7 \%$ people. Average parameters in local population didn't have any authentic discrepancies.

We detected a 33.3\% decrease in enamel resistance as per ER-test, $\mathrm{p}=0.0017$ (the parameter grew to $5.1 \pm 0.17$ scores). Initially, it was lower than 3 scores in
$53.3 \%$ which was the evidence that their enamel was substantially resistant to caries; the rest ran some risks of caries evolvement. By the end of the observations, $100.0 \%$ of the examined people ran this risk. ER-test results for local population didn't have any authentic discrepancies with the data obtained in group 1: ER-test showed caries evolvement risk for $80.0 \%$ of them; as for the rest $20.0 \%$, they ran high risk of caries evolvement (Table 2).

Table 2

Dental state characteristics in both groups, $(M \pm m)$

\begin{tabular}{|c|c|c|c|}
\hline \multirow[b]{2}{*}{$\begin{array}{l}\text { Dental state parame- } \\
\text { ters, reference limits }\end{array}$} & \multicolumn{2}{|c|}{ Observation period } & \multirow[b]{2}{*}{$p$} \\
\hline & $\begin{array}{c}\text { Local } \\
\text { population }\end{array}$ & $\begin{array}{c}\text { Group 1 } \\
\text { (23-rd day) }\end{array}$ & \\
\hline $\begin{array}{l}\text { Saliva } \mathrm{pH}, 6.8-7.4 \\
\text { units }\end{array}$ & $6,61 \pm 0,08$ & $6,66 \pm 0,08$ & 0,352 \\
\hline $\begin{array}{l}\text { Saliva mineralizing } \\
\text { potential, } 1-5 \text { scores }\end{array}$ & $2,8 \pm 0,2$ & $2,6 \pm 0,16$ & 0,272 \\
\hline $\begin{array}{l}\text { Salivation rate, } 18- \\
111,0 \mathrm{ml} / \mathrm{h}\end{array}$ & $\begin{array}{c}25,02 \pm \\
1,22 \\
\end{array}$ & $\begin{array}{c}23,92 \pm \\
1,36 \\
\end{array}$ & 0,236 \\
\hline ER-test, 1-10 scores & $5,1 \pm 0,22$ & $5,1 \pm 0,17$ & 0,5 \\
\hline
\end{tabular}

Conclusions:

1. When people had to undergo acclimatization to hot humid sea climate conditions and simultaneously had to work under hazardous working conditions a disorder occurred in their electrolyte balance which was proved by lower $\mathrm{K}, \mathrm{Na}$, and $\mathrm{Cl}$ concentrations in their blood serum. Electrolyte imbalance was less apparent in local population.

2. $70.0 \%$ of local people had Ca concentration in their blood serum lower than the standard. We also detected a decrease in $\mathrm{Ca}$ concentration and an increase in $\mathrm{P}$ concentration in blood serum of people under acclimatization; and $\mathrm{Ca}: \mathrm{P}$ ratio in them changed until it reached the values detected in local population. These data were the evidence Ca was possibly washed out of a body and it led to higher teeth caries risk.

3. Dynamic observations performed on people who came to work in a hot humid 
sea climate revealed that processes related to teeth solid tissue demineralization occurred in them: saliva $\mathrm{pH}$ shifted towards acidity, saliva mineralizing function weakened, salivation rate fell, and enamel re- sistance deteriorated. Therefore, we can state that activities aimed at primary prevention of caries in teeth solid tissues are truly essential.

\section{References}

1. Alimova Z.A., Kurgul'skij A.G. Kriterii ocenki sostojanija stomato-logicheskogo zdorov'ja sotrudnikov specsluzhb: Metodicheskie rekomendacii [Assessment criteria for assessing dental health of special services staff: Methodological Guidelines]. N. Novgorod, izd-vo NGMA, Publ., 2008, 31 p. (in Russian).

2. Emelina G.V., Grinin V.M., Ivanov P.V., Kuznecov N.K., Zljul'kina L.A. Analiz stomatologicheskoj zabolevaemosti $\mathrm{v}$ vybore metodov i podhodov individual'noj profilaktiki kariesa zubov i zabolevanij parodonta [The analysis of dental disease in the choice of methods and approaches of individual prevention of individual prevention of dental caries and paradont diseases]. Sovremennye problemy nauki i obrazovanija, 2011, no. 2, pp. 9-10 (in Russian).

3. Borisenko L.G. Struktura zabolevaemosti slizistoj obolochki rta sredi naselenija starshih vozrastnyh grupp Respubliki Belarus' [Morbidity structure of mucous tunics diseases in oral cavity among elderly age groups in Belarus]. Studopedija, 2015. Available at: https://studopedia.su/18 158265 metodi-prognozirovaniya-kariesa-zubov-primenenieprogrammi-kariogramma-v-prognozirovanii-kariesa-zubov.html (26.06.2015) (in Russian).

4. Kishkun A.A. Rukovodstvo po laboratornym metodam diagnostiki [Guide on laboratory diagnostics techniques]. Moscow, GJeOTAR-Media, Publ., 2009, 800 p. Available at: http: //www.rosmedlib.ru/book/ISBN5970411728.html (24.08.2017) (in Russian).

5. Hafizov R.G., Azizova D.A., Hafizova F.A., Zaripova Je.M., Zhidko A.K. Sovremennye materialy i metody profilaktiki stomatologicheskih zabolevanij: uchebno-metodicheskoe posobie [Contemporary data and techniques for dental diseases prevention: a manual]. Kazan',

Kazanskij universitet, Publ., 2014, 52 p. Available at: http: //dspace.kpfu.ru/xmlui/handle/net/21514 (22.08.2017) (in Russian).

6. Anil S., Anand P.S. Early Childhood Caries: Prevalence, Risk Factors, and Prevention. Front. Pediatr, 2017, no. 5, pp. 157. DOI: 10.3389/fped.2017.00157.

7. Bowen WH. Do we need to be concerned about dental caries in the coming millennium? Crit. Rev. Oral. Biol. Med., 2002, vol. 13, no. 2, pp. 126-131.

8. Brambilla E., Garcia-Godoy F., Strohmenger L. Principles of diagnosis and treatment in high-caries-risk subjects. Dent. Clin. North Am, 2000, vol. 44, pp. 507-540.

9. Sälzer S., Alkilzy M., Slot D.E., Dörfer C.E., Schmoeckel J., Splieth C.H.; Chairs of Working Group 3; ORCA. Socio-behavioural aspects in the prevention and control of dental caries and periodontal diseases at an individual and population level. J. Clin. Periodontol., 2017, vol. 44, no. 18, pp. S106-S115.

10. Cummins D. Dental caries: a disease that remains an urgent public health and health problem in the 21 st century. The exploration of a breakthrough technology for caries prevention. Journal of Clinical Dentistry, 2013, vol. 24, Spec Iss. A, pp. A1-14.

11. Cummins D. The impact of research and development on the prevention of oral diseases in children and adolescents: an industry perspective. Pediatr. Dent., 2006, vol. 28, pp. 118-127.

12. Cummins D., Bowen WH. Biotechnology in oral care. Cosmetic Science and Technology Series. In: R. Lad, ed. New York, Taylor and Francis Ltd, 2006, vol. 29, Biotech in Personal Care, pp. 323-352. 
13. Hayes M.J., Cheng B., Musolino R., Rogers A.A. Dietary analysis and nutritional counselling for caries prevention in dental practise: a pilot study. Aust. Dent. J., 2017, vol. 64, no. 4, pp. 485-492. DOI: 10.1111/adj.12524.

14. Featherstone J.D. Caries prevention and reversal based on the caries balance. Pediatr. Dent., 2006, vol. 28, pp. 128-132.

15. Fejerskov O. Changing paradigms in concepts on dental caries: consequences for oral health care. Caries. Res., 2004, vol. 38, pp. 182-191.

16. Marsh P.D., Percival R.S. The oral microfl ora friend or foe? Can we decide? Int. Dent. J., 2006, vol. 56, no. 1, pp. 233-239.

17. Jepsen S., Blanco J., Buchalla W., Carvalho J.C., Dietrich T., Dörfer C., Eaton K.A., Figuero E., Frencken J.E., Graziani F. Prevention and control of dental caries and periodontal diseases at individual and population level: consensus report of group 3 of joint EFP/ORCA workshop on the boundaries between caries and periodontal diseases. J. Clin. Periodontol., 2017, vol. 44, no. 18, pp. S85-S93.

18. Jørgensen M.R., Castiblanco G., Twetman S., Keller M.K. Prevention of caries with probiotic bacteria during early childhood. Promising but inconsistent findings. Am. J. Dent., 2016, vol. 29, no. 3, pp. 127-131.

19. Reynolds E.C. Calcium phosphate-based remineralization systems: scientific evidence? Issue Australian Dental Journal, 2008, vol. 53, no. 3, pp. 268-273.

Rakhmanov R.S., Alikberov M.Kh., Omarova Z.A. Factors causing risks of caries evolvement in dental solid tissues under acclimatization. Health Risk Analysis, 2017, no. 4, pp. 91-96. DOI: 10.21668/health.risk/2017.4.10.eng

Received: 29.09.2017

Accepted: 18.12.2017

Published: 30.12.2017 
UDC 613.64

DOI: 10.21668/health.risk/2017.4.11.eng

\title{
ANALYSIS OF HAZARDOUS WORK ENVIRONMENT FACTORS AT A TRAIN CONDUCTOR WORKPLACE
}

\author{
M.F. Vil'k' , O.S. Yudaeva1, V.A. Aksenov², V.M. Ponomarev², V.I. Apattsev², \\ E.A. Sorokina ${ }^{2}$, V.B. Prostomolotova ${ }^{2}$, A.S. Kozlov ${ }^{2}$, E.O. Latynin ${ }^{1}$ \\ ${ }^{1}$ All-Russian Research Institute of Railway Hygiene, 1, Bldg. 1 Pakgauznoe Shosse Str., Moscow, 125438, \\ Russian Federation \\ ${ }^{2}$ Russian University of Transport (MIIT), 9, Bldg 9 Obrazcova Str., Moscow, 127994, Russian Federation
}

The paper dwells on generalized analysis of morbidity which is characteristic for conductors working in passenger carriages of locomotive-driven trains. Working conditions train conductors had to work in were examined as per results of sanitary-hygienic research on intra-carriage environment, specific working conditions assessment, and questioning. Hazards caused by working environment factors for train conductors to a certain extent depend on a carriage type, its technical and hygienic state, as well as on a route a train goes by.

Our research revealed that impacts exerted by various working environment factors, namely physical, chemical, biological, and psychophysical ones, caused respiratory diseases, increased allergic reactivity, changes in hearing sensitivity, and overall morbidity growth among people from this occupational group.

Unordered regime resulting from constant trips and unfavorable living conditions in a carriage lead to the following diseases: varix dilatation in legs, ischemic heart disease together with primary hypertension, and chronic rheumatic heart diseases. More precise classification of conductors' working conditions can be obtained via a mathematical model creation as it enables precise estimation of occupational diseases probability. Such models should be based on a relationship between diseases frequency (or probability) and working conditions as per specific hygienic factors.

We worked out methodical guidelines on providing safe working conditions at conductors' working places which include efficient activities aimed at prevention of hazardous impacts exerted by working environment factors. It will help to improve working conditions substantially, to preserve workers' health, and to ensure safe passengers traffic.

Safe working conditions for conductors can be secured due to a set of activities aimed at equipping new carriages and those after capital repair with air-conditioning, disinfection systems, heating, ecologically clean toilets, modern furnishing materials, as well as at improving sanitary and living conditions, providing comfortable uniforms, and better regulation of work and rest regimes.

Key words: conductor, passenger carriage, working environment factor, morbidity, sanitary-hygienic research, labor protection.

(C) Vil'k M.F., Yudaeva O.S., Aksenov V.A., Ponomarev V.M., Apattsev V.I., Sorokina E.A., Prostomolotova V.B., Kozlov A.S., Latynin E.O., 2017

Mikhail F. Vil'k - Doctor of Medical Sciences, Professor, Head (e-mail: info@vniijg.ru; tel.: +7 (499) 153-27-37).

Oksana S. Yudaeva - Doctor of Technical Sciences, Associate Professor, leading researcher at Communal Hygiene and Epidemiology Laboratory (e-mail: vniijg@yandex.ru; tel.: +7 (926) 899-73-06)

Vladimir A. Aksenov - Doctor of Technical Sciences, Professor, Head (e-mail: tu@miit.ru; tel.: +7 (495) 799-9559).

Valentin M. Ponomorev - Doctor of Technical Sciences, Professor, Head of "Safety Management in Technosphere" Department (e-mail: elozovskiy@miit.ru; tel.: +7 (985) 9985719). 01).

Vladimir I. Apattsev - Doctor of Technical Sciences, Professor, Head (e-mail: apatsev@rgotups.ru; tel.: +7 (495) 649-19-

Ekaterina A. Sorokina - postgraduate student at "Technosphere Safety" Department (e-mail: pingvin2800@gmail.com; tel.: +7 (916)904-87-54).

Viktoriya B. Prostomolotova - postgraduate student at "Technosphere Safety" Department (e-mail: vikieco@yandex.ru; tel.: +7 (917) 592-01-56).

Aleksandr S. Kozlov - postgraduate student at "Technosphere Safety" Department (e-mail: kozlovas@,rqst.ru; tel.: +7 (985) 777-05-05).

Evgenii O. Latynin - Deputy Director responsible for development (e-mail: jeckkk@rambler.ru; tel.: +7 (916) 624-2996). 
Russian Railways PLC pursues a consistent policy concerning labor protection; the policy is aimed at minimizing risks for occupational injuries and accidents and at maintaining maximum possible safety of all the technological processes in the company.

In 2009 Russian Railways PLC set a technical task to manufacture a range of twostorey passenger carriages for locomotivedriven trains; the main purpose was to implement innovative life support systems, to achieve greater labor productivity of train conductors, to increase constructional speed, to lower life cycle costs per one passengerplace, to decrease energy consumption, and to ensure high social and economic performance figures $[3,13]$.

"On railways rolling stock safety" Customs Union Technical Regulations (TP TC 001/2011) ${ }^{1}$ were based on the RF Federal law "Technical Regulations on fire safety requirements" dated July 22, 2008 No. 123-FL (last edited on July 02, 2013) ${ }^{2}$, these regulations set forth all the requirements to railway rolling stock and its components in order to ensure people's life and health safety. But provision of safety working conditions for train conductors involves working out and updating regulatory-technical and methodological grounds, sanitary-hygienic assessment of environmental factors inside a carriage, and developing recommendations on working conditions improvement.

It is known that carriages costs amount to $20 \%$ of all the railways fixed assets; personnel occupied with passenger carriages maintaining and technical support has approximately the same share among all the railway employees; $60-80 \%$ of this car- riages maintenance staff are women [8].

A train conductor is one of the most widely spread occupations in railway transport; their quantity amounts to approximately 41,000 employees. But still working conditions for these people, both in old and modern carriages, have not been given sufficient attention. Hazard caused by occupational factors for train conductors to a certain extent depends on a carriage type, its technical and hygienic state, as well as on a route a train goes by.

According to the existing data, impacts exerted on workers by physical, chemical, biological, and psychophysical occupational factors cause respiratory diseases, increased allergenic reactivity, changes in auditory sensitivity, and increase in overall morbidity among them. Female workers, beside all that, suffer from disorders in specific female body functions, namely gynecological diseases, and complications during pregnancy and childbirth. A train conductor occupation belongs to a group with the highest occupational risks $[5,6,9,10,12]$. All the above stated proves that a problem of providing safe working conditions for train conductors is truly vital.

As per research data, overall morbidity with temporary disability among train conductors is two times higher than in the branch on average.

Impacts exerted by occupational factors mostly depend on specificity of work tasks a train conductor has to perform as well as on peculiarities of labor organization and working conditions which are characteristic for this occupation only. And here a number of detected adverse occupational factors which exist at conductors' workplaces can't be elim-

\footnotetext{
${ }^{1}$ On railways rolling stock safety: Customs Union Technical Regulations (TP TC 001/2011). Available at: http://webportalsrv.gost.ru/portal/GostNews.nsf/acaf7051ec840948c22571290059c78f/31df4d876b7c282244257a3 7003e01d3/\$FILE/TR_TS_001-2011_text.pdf(07.08.2017).

${ }^{2}$ Federal law dated July 22, 2008 No. 123-FL. Available at: http://docs.cntd.ru/document/902111644 (07.08.2017).
} 
inated directly by any organizational or prevention activities $[7,17]$.

We should note that previous research on conductors' working conditions and morbidity didn't allow for properties of life support systems in up-to-date rolling stock, including two-storey passenger carriages.

Train conductors occupation involves constant travelling, and most conductors have to make long trips lasting from 3 to 7 days.

Experts at Russian Railways PLC perform specialized working conditions assessment as per established procedures in order to provide safe working conditions for train conductors $[1,4,14-16]$.

We can highlight the following basic hazardous and adverse factors related to train conductors occupation: vibration, noise, dustiness, adverse chemicals, luminance, unfavorable microclimate, labor hardness and intensity. Undoubtedly all these adverse occupational factors influence conductors' working conditions and cause their health deterioration $[2,8,18]$.

Experts at Russian Scientific Research Institute for Railway Hygiene conducted research on working conditions and morbidity of passenger carriages conductors. The research results revealed that their morbidity structure had certain peculiarities: conductors mostly suffered from respiratory organs diseases, circulatory system diseases, musculoskeletal system diseases, injuries, and allergy. Those parameters were related not only to age peculiarities of the examined worker but also to specific factors attributable to occupational activities of these railway transport workers.

We also noted that working conditions of passenger carriages conductors involved influence exerted on their bodies by a set of adverse occupational factors, namely overall transport vibration, noise, cooling and heating microclimate, and high neuro-emotional stress. Unfavorable sanitary-hygienic working conditions of train conductors were basically caused by the following: some carriages in operation were not fully equipped with all the necessary components of life support systems; work tasks were not automated enough and had to be performed by hand; carriages interior was not rationally planned and organized; ventilation wasn't efficient; sanitary and communal services were unsatisfactory; labor, rest, and nutrition regimes were not rational.

In 2011 "Tverskoy Carriage Works" PLC started manufacturing various prototypes of two-storey passenger carriages in order to conduct performance tests and to determine sanitary and hygienic standards for them.

Conductors' working conditions were analyzed as per sanitary-hygienic research data and questioning results. Tests were performed in old passenger carriages. Such carriages weren't equipped with air conditioning, water and air disinfection systems, and ecologically clean toilets; finishing and heatinsulating materials in them were of poor quality or even absent; the carriages didn't conform to sanitary-hygienic, toxicological, and fire safety requirements (Figure 1).

There was also comparative research on working environment conditions for train conductors, and their labor hardness and intensity in one-storey old carriages (2002) and two-storey new ones (2013). The research results are given in Figure 2. The results of specific working conditions assessment in the same carriages are shown in Figure 3.

Given all the working environment factors exerting their influence independently, we calculated an aggregated risk level and applied a model incorporating scores of working environment and labor hardness (Figure 4). 


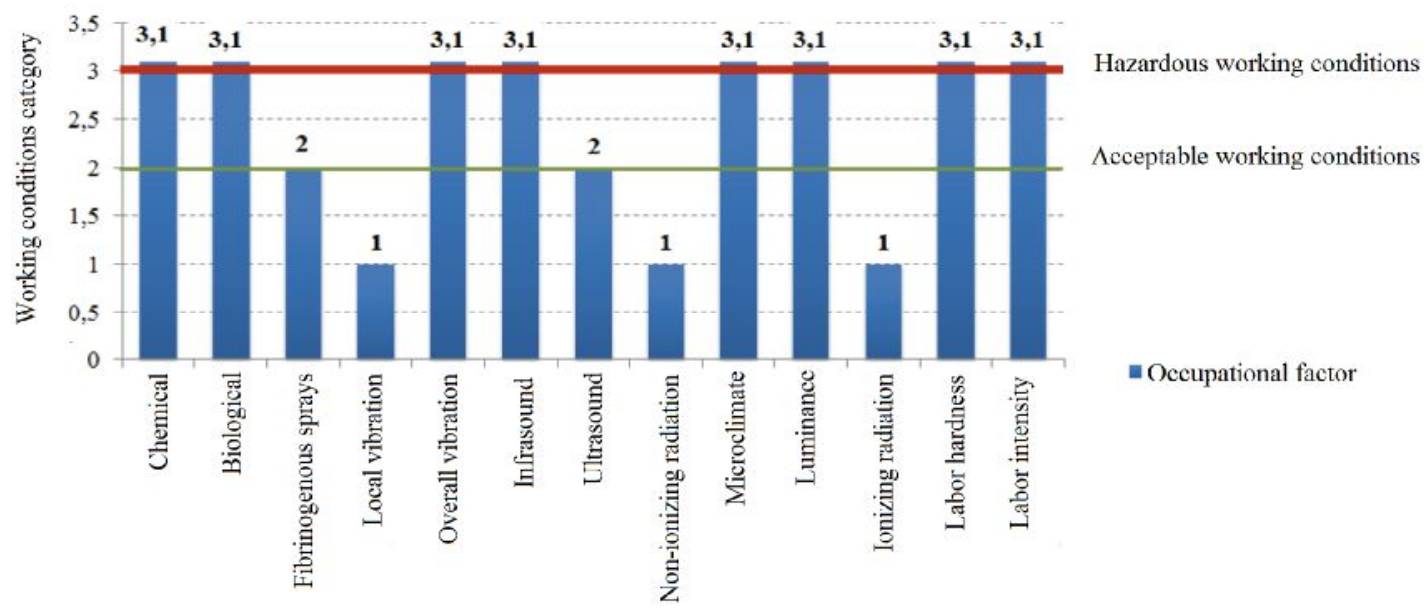

Figure 1. Working conditions at train conductors' workplace: analysis results

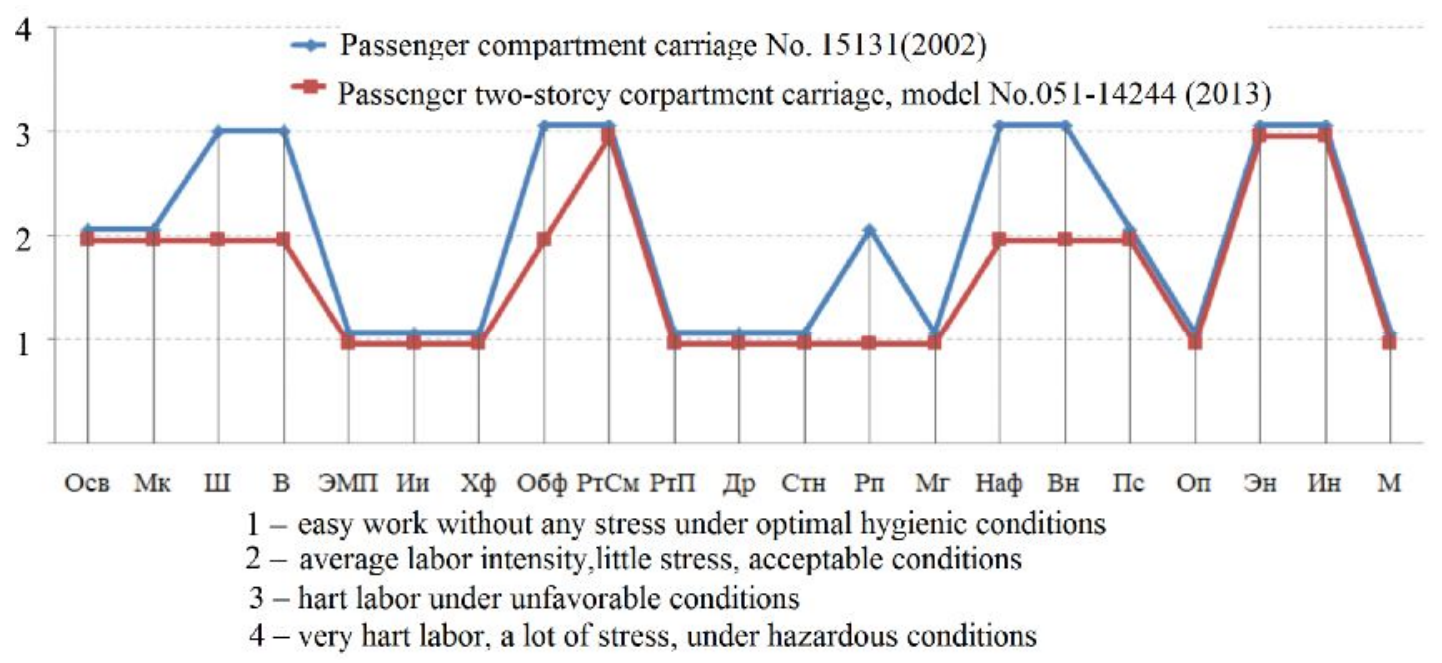

Figure 2. Description of working environment conditions, and labor hardness and intensity for train conductors

Note: here and in Fig. 3 conventions:

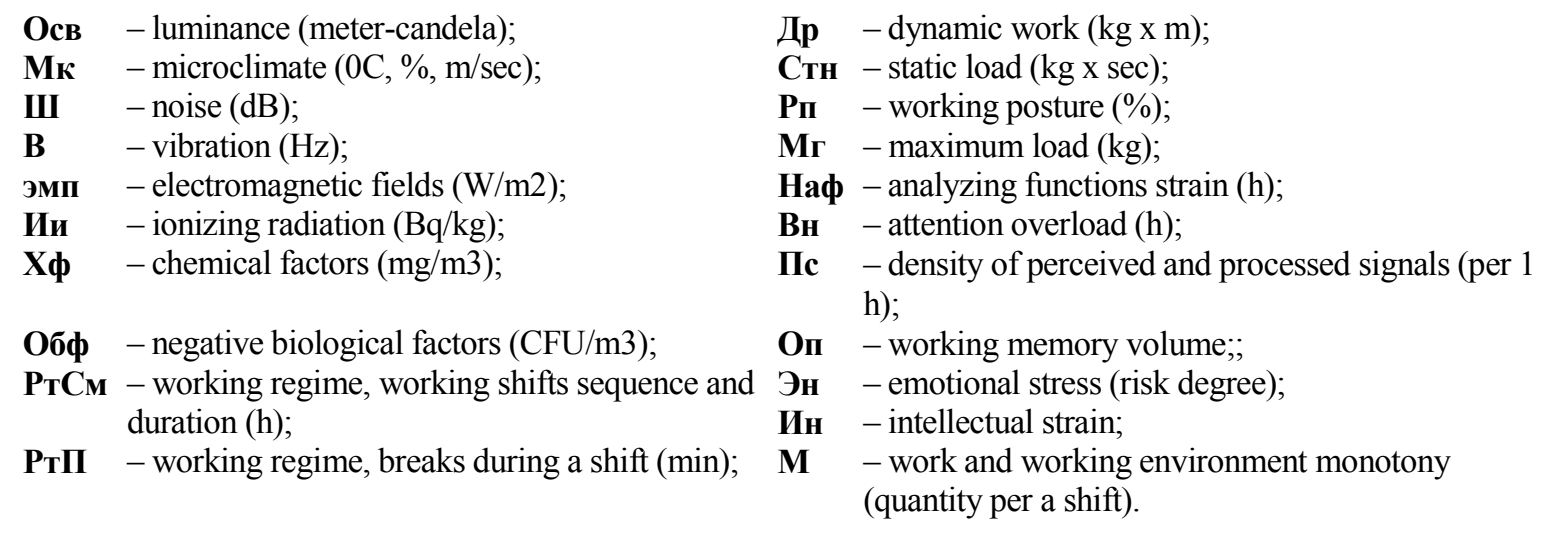




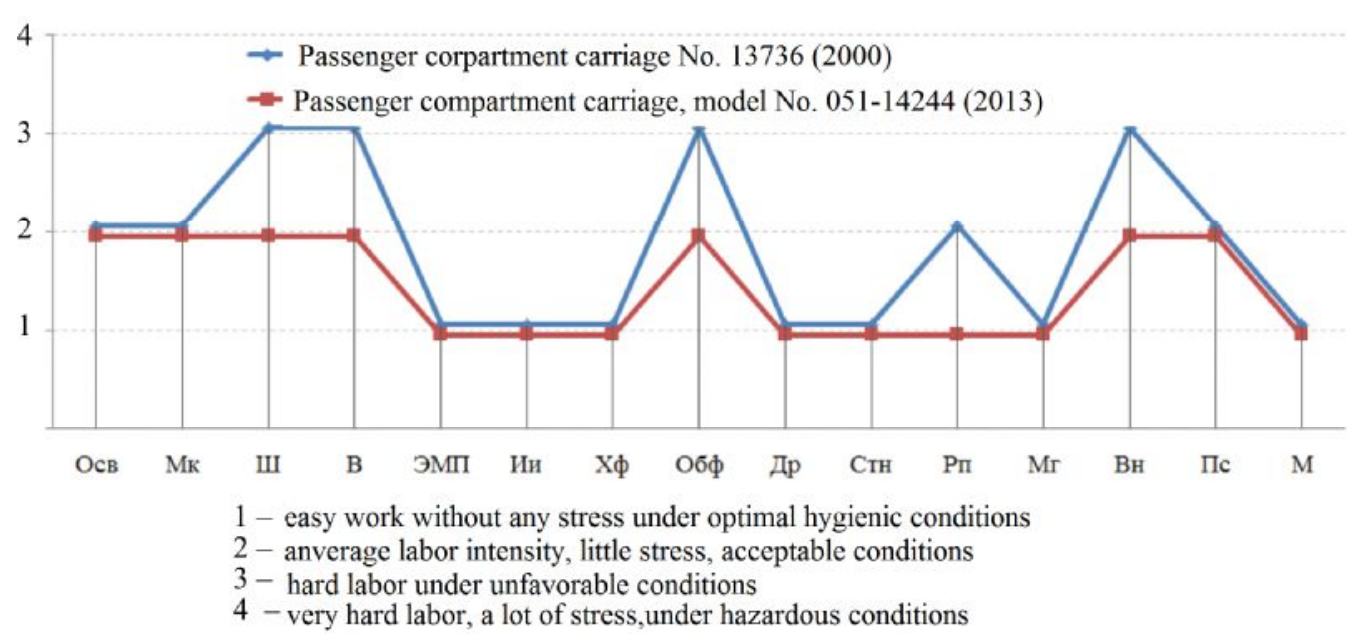

Figure 3. Specific assessment of working conditions for passenger carriages conductors
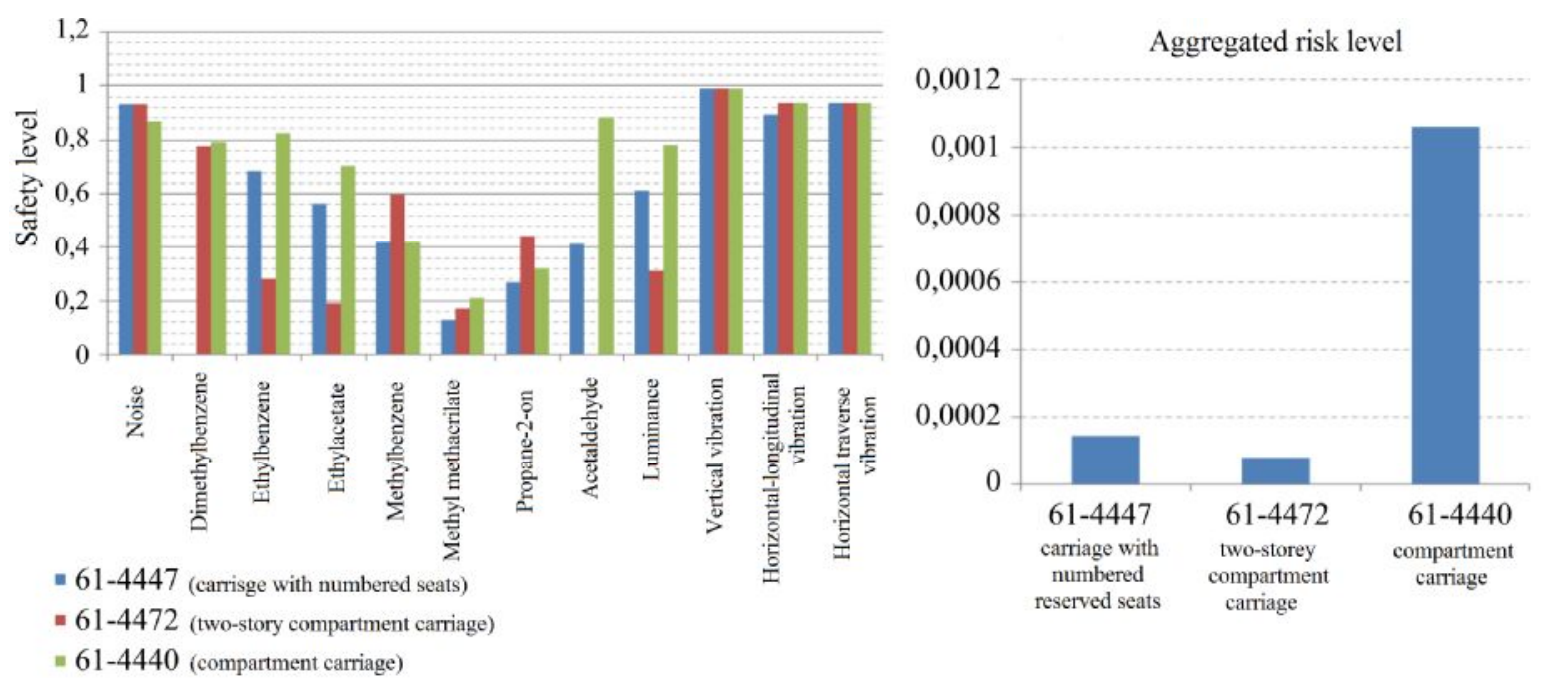

Figure 4. Occupational factors safety for passenger carriages conductors

Though all the scores given to the examined occupational factors correspond to acceptable working conditions category, an aggregated risk level is still rather high. So, the applied calculation model confirms that it is necessary to adopt a complex approach to occupational risk analysis as it allows to assess influence exerted on health simultaneously by several occupational factors.

Our paper also contains an aggregated analysis of passenger carriage conductors morbidity.

Morbidity with temporary disability amounts to 113.1 cases and 1,505.8 days per 100 conductors. Morbidity parameter related to taking care after a sick family member amounts to 13.4 cases per 100 workers; sick leaves related to childbirth are 15.3 cases per 100 workers. Overall morbidity with temporary disability among train conductors is two times higher than the same parameter in the branch as a whole. $89 \%$ of all morbidity cases belong to 7 basic nosologies: respiratory organs diseases, circulatory system diseases, nervous system and sense organs diseases, musculoskeletal system diseases, digestive organs diseases, and injuries.

Respiratory organs diseases among train conductors account for $56 \%$ of all the morbidity cases, and their share is the big- 
gest. Respiratory organs diseases cause more than a half of temporary disability cases; they are mostly acute respiratory diseases, rhinitis, bronchitis, and pneumonia; it is obviously related to influence exerted by hazardous temperature differences, especially during a cold season when train conductors have to exit from a warm carriage onto a platform. It all indicates that working conditions for train conductors need to be improved. Besides, respiratory organs diseases among train conductors cause loss of occupational fitness due to poor health authentically more frequently (by 12.5\%) in comparison with other railway workers. Most frequent diseases here are bronchial asthma and other recurrent bronchial-lungs system diseases caused by high bacterial contamination of the air inside a carriage, various chemicals contents in it, as well as by unfavorable microclimate.

A so called "share of workers who were ill" parameter prevails among train conductors and is equal to $46.8 \%$ (while an average branch one is equal to $40 \%$ only). Besides, a number of workers who have this occupation and can be included into a group of "frequently and long sick people" is also higher than in the branch on average ( $8 \%$ against $6.7 \%$ ).

Results of sociological questioning conducted among this occupational group reveal there are objective conditions and risk factors causing acute and chronic diseases in train conductors:

- influence exerted by a number of working environment factors during roundthe-clock staying inside a carriage (microclimate, noise, vibration, ultrasound, luminance, and chemicals);

- physical loads and significant neuroemotional stress;

- unordered working regime;

- night and day shifts;
- unfavorable sanitary and communal conditions (insufficient motor activity (hypokinesis), constant violation of nutrition, sleep, and rest regimes, absence of possibility to maintain personal hygiene). We also detected that possibilities for physiological and psychological functions recovery were not properly provided and this process organization had a number of drawbacks.

Results of research conducted by A.A. Prokhorov, and V.A. Kudrin [11], which considered conductors' health disorders in view of their occupational activity contain very interesting data on how fast conductors' biological ageing is; the data show that the speed of the process increases greatly at the age from 18 to 27 , and from 38 to 42 . The discrepancy between a true age and a calendar one amounts to 2-3 years during first 10 years of working as a train conductor; when working experience amounts to 16-20 years, this discrepancy grows up to 9 years and remains stable at 3 years when working experience is between 20 and 36 years.

As we studied morbidity structure as per various temporary disability causes taking data from the results of complex medical examinations conducted by experts from Russian Scientific Research Institute for Railway Hygiene, we were able to determine that morbidity among passenger carriages conductors was rather high. It was especially high among people aged 3039 and 40-49.

Respiratory organs diseases (ARVI, angina, laryngitis, tracheitis, and flu) had the greatest specific weight in all age groups.

Rank places in morbidity structure are as follows:

1 rank place belongs to respiratory organs diseases $(56 \%)$;

2 rank place belongs to circulatory system diseases $(6,9 \%)$; 
3 rank place, to musculoskeletal system and connective tissue diseases $(6,6 \%)$;

4 rank place, digestive organs diseases $(4,9 \%)$;

5-6 places are held by skin and subcutaneous tissue diseases, injuries and intoxications $(4,4 \%)$.

We can clearly determine a group of diseases which are closely related to peculiarities of train conductors work in the overall morbidity structure; these diseases are acute respiratory viral infections, flu, angina, nerve plexus diseases, osteoarthritis, radiculitis, stomach and duodenum ulcer, acute gastritis, pyoderma and fungus skin diseases.

Unordered working regime involving a lot of travelling and unfavorable communal conditions in a carriage obviously causes the following diseases: varix dilatation in legs (1.0 case per 100 workers), ischemic heart diseases with primary hypertension (1.1 cases per 100 workers), primary hypertension (4.4 cases per 100 workers), chronic rheumatic heart disease ( 1.1 cases per 100 workers). Skin diseases among train conductors occur 3 times more frequently than in the branch on average.

Circulatory system diseases include the following: primary hypertension, nonrheumatic heart diseases, atherosclerosis, phlebitis, and thrombophlebitis.

Morbidity analysis revealed that nervous system diseases and sense organs diseases occurred among train conductors authentically more frequently than among workers from the comparison group. As for specific nosologies, we detected that conductors more frequently suffered from such diseases as neuritis, neuralgia, inflammatory eyes diseases, and otitis.

We detected that such adverse occupational factors as vibration, dustiness, and neuro-emotional loads, caused disorders in normal adaptation, and activated regulatory mechanisms responsible for specific adaptation and non-specific stress syndrome.

Interesting data with a great practical significance were obtained in the course of research on a group of conductors who had to travel for a long time in different time zones as they went on a train Moscow Vladivostok - Moscow, 14 days overall. They travelled across 6 time zones during their whole trip. Basic age group was 21$33(76 \%$ of the examined workers), prevailing working experience was equal to 15 years $(69 \%)$. All the examined workers were practically healthy but before their trip they complained on considerable fatigability, tiredness, and low working capacity. Such complaints grew stronger after a trip. Besides, after a trip conductors also complained on sleep disorders related both to sleep and wake regime violations (night shifts) and to different time zones and break of daily biorhythms. Closer to an end of a trip eastward they had difficulty in falling asleep, or they fell asleep too fast and woke after a very short sleep (only 1-2 hours). Sleep didn't help to get needed rest and to recover psychological and physical working capacity. All the data on train conductors state before and after a trip revealed that long-term trips in equatorial direction exerted considerable negative influence on a body which caused substantial decrease in its adaptive abilities, antimicrobe protection, and anti-oxidant state; it all could eventually lead to various infectious and non-infectious diseases occurrence.

More than a half of all the questioned conductors were 40-50 years old. As per statistic data, in 2007 30-40 age group prevailed, and we can state that workers' average age grew. Duration of working experience as "passenger carriage conductor" also increased considerably: in $200745 \%$ 
workers had working experience equal to 10 and more years; in 2014 share of such workers grew up to $57 \%$. Such parameters as overall morbidity, and a share of workers who were sick among conductors, correlate with workers' age and working experience; therefore, such a trend can lead to growth in morbidity cases among workers.

Working experience in up-to-date rolling stock generally is not longer than 3 years ( $47 \%$ of the questioned).

Female conductors amounted to $72 \%$, and it was lower than in 2007 (83\%); still, a share of female workers among train conductors remains substantially high.

Workers gave their own assessment of how often they were sick: $47 \%$ on average 1 time a year; $26 \%$ were rarely sick; $24 \%$ were sick 2-3 times a year; $3 \%$, more than 5 times a year. A mathematical model can help to obtain more precise classification of conductors' working conditions; such a model precisely assesses occupational diseases probability. The model is based on a relationship between diseases frequency (or probability) and labor situation as per specific hygienic factors.

So, to sum up results of our work dedicated to analyzing functional and physiological peculiarities, state of a body, and occupational activities of train conductors, we should point out that we revealed grave strain in background parameters of psychophysiological functions used in conductors' occupational activities, as well as adaptation-compensatory reactions violation; all this makes health disorders among this occupational group much more probable. Data obtained by a number of researchers prove there is neuro-emotional stress in conductors, especially during long trips.

We can say that all the obtained data undeniably prove occupational causality of morbidity with temporary disability among passenger carriages conductors.

The performed analysis revealed that overall morbidity among train conductors was growing. But passenger carriages conductors who were younger than 50 fell sick less frequently in comparison with other occupational groups; morbidity escalated only among people older than 50 .

In the course of our research we developed a set of priority measures aimed at providing safe working conditions for train conductors (Figure 5). The suggested system should help to solve vital tasks on hygienic optimization and passenger transportation safety, occupational environment improvement, prevention of morbidity among passenger carriages conductors; today, it can be taken as a generic one in labor protection activities in passenger transportation sphere.

We developed methodical recommendations on providing safe working conditions at train conductors' workplaces; they include efficient activities aimed at prevention of unfavorable influence exerted by adverse occupational factors and will allow to improve working conditions considerably, to preserve health, and to provide safety (Figure 6). A set of measures was implemented in equipping new carriages and carriages after capital repair; the carriages were equipped with air-conditioning units, disinfection units, heating, ecologically clean toilets; up-to-date finishing materials were applied during repairing; sanitary and communal conditions in the carriages were improved. Conductors were provided with comfortable uniforms, their rest and work regimes were better regulated; all the above-mentioned helped to provide working conditions with 2 nd hazard degree (acceptable ones) additionally for $22 \%$ conductors over the last 5 years. 


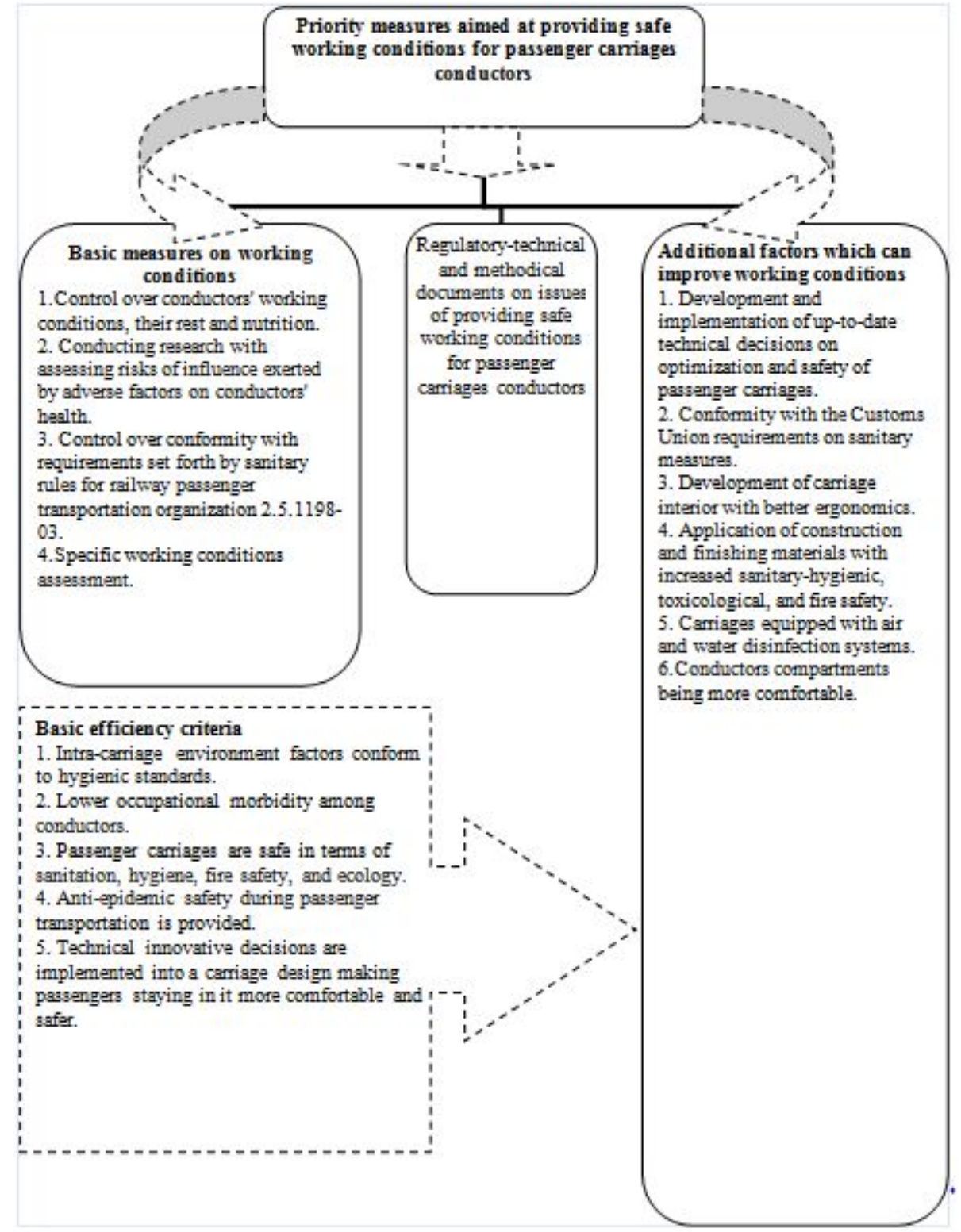

Figure 5. A set of priority measures aimed at providing safe working conditions for passenger carriages conductors

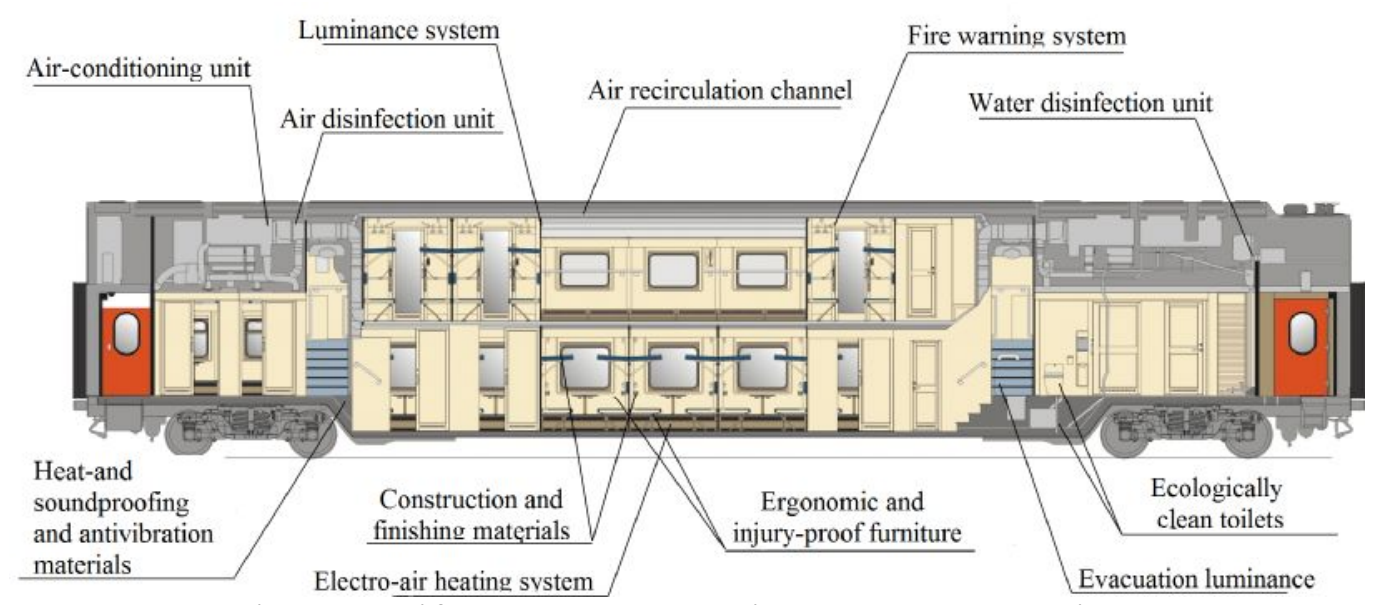

Figure 6. Life support systems in a two-storey carriage 


\section{References}

1. Belyakov G.I. Okhrana truda [Labor protection]. Moscow, Yurait, Publ., 2013, 572 p. (in Russian).

2. Gigiena truda [Occupational hygiene].In: N.F. Izmerov, V.F. Kirillov, eds. Moscow, GEOTAR-Media, Publ., 2008, 592 p. (in Russian).

3. Saikin A.M., Ryabchikov O.B., Yudaeva O.S., Zaikov G.E. K otsenke ekologichnosti i pozharobezopasnosti polimersoderzhashchikh materialov inter'era ATS [An assessment of ecological and fire safety of polymer-containing materials into vehicle interior]. Trudy NAMI, 2012, no. 248, pp.78-91(in Russian).

4. Klochkova E.A. Okhrana truda na zheleznodorozhnom transporte [Labor protection at railroad transport]. Moscow, Marshrut, Publ., 2004, 412 p. (in Russian).

5. Kommunal'naya gigiena [Communal hygiene]. In: V.T. Mazaev, ed. Moscow, GEOTAR-Media, Publ., 2005, part 2, 304 p. (in Russian).

6. Mel'nichenko P.I., Prokhorov N.I., Arkhangel'skii V.I. Obshchaya gigiena, sotsial'nogigienicheskii monitoring: rukovodstvo k prakticheskim zanyatiyam. Razdel «Obshchaya gigiena» [Common hygiene, social-hygienic monitoring: practical studies guide. "Common hygiene" section]. Moscow, Prakticheskaya meditsina, Publ., 2014, 332 p. (in Russian).

7. Ponomarev V.M., Ul'yanov V.A. Vliyanie motivatsii truda na povyshenie bezopasnosti proizvodstvennoi deyatel'nosti personala [Influence exerted by labor motivation on increasing safety of staff production activities]. Nauka i tekhnika transporta, 2012, no. 2, pp. 106-112 (in Russian).

8. Potapov A.I, Titova T.S. Ekologicheski bezopasnye tekhnologii na zheleznodorozhnom transporte [Environmentally safe technologies in railway transport]. Transport Rossiiskoi Federatsii, 2010, vol. 31, no. 6, pp. 72-77 (in Russian).

9. Professional'nye zabolevaniya: rukovodstvo [Occupational diseases: Guide]. In: N.F. Izmerov, ed. Moscow, Meditsina, Publ., 1996, vol. 1, 336 p. (in Russian).

10. Professional'nye zabolevaniya: rukovodstvo [Occupational diseases: Guide]. In: N.F. Izmerov, ed. Moscow, Meditsina, Publ., 1996, vol. 2, 480 p. (in Russian).

11. Prokhorov A.A., Kudrin V.A. Okhrana zdorov'ya rabotnikov lokomotivnykh brigad I obespechenie bezopasnosti dvizheniya poezdov na zheleznykh dorogakh: rukovodstvo [Protecting health of locomotive teams and providing railroad traffic safety: Guide]. Moscow, VNIIZhG MPS Rossii, Publ., 2000, 107 p. (in Russian).

12. Rossol'ko D.S. Osobennosti trudovoi deyatel'nosti i sostoyanie reproduktivnogo zdorov'ya zhenshchin-provodnikov zheleznodorozhnogo transporta: avtoref. dis.. kand. med. Nauk [Working activities peculiarities and reproductive health of female conductors at railroad transport: abstracts of a candidate's dissertation]. Sankt-Peterburg, 2005, 20 p. (in Russian).

13. SP 2.5.1198-03. Sanitarnye pravila po organizatsii passazhirskikh perevozok na zheleznodorozhnom transporte. Utv. Glavnym gosudarstvennym sanitarnym vrachom Rossiiskoi Federatsii [Sanitary rules for passenger traffic on railroad. Approved by the RF Chief State Sanitary Inspector]. 2003. Available at: https://ohranatruda.ru/ot_biblio/norma/249197/ (30.07.2017) (in Russian).

14. STO RZhD 1.15.003-2008. Proizvodstvennyi kontrol' uslovii truda v OAO «RZhD»: standart OAO «RZhD» [STORR 1.15.003-2008. Industrial surveillance over working conditions in Russian Railways PLC RR PLC Standard]. Available at: www.ttgdt.edu.ru/students/railway/sto/sto\%20rzd\%201.15.003-2008.pdf (08.08.2017) (in Russian).

15. STO RZhD 15.012-2014. Sistema upravleniya okhranoi truda v OAO «RZhD». Spetsial'naya otsenka uslovii truda: standart OAO «RZhD» [STORR 15.012-2014. Labor protection 
system in RR PLC. Specific assessment of working: PLC RR PLC Standard]. Available at: www.dorprof-kbsh.ru/wp-content/uploads/S-STO-RZhD-15.012-2014-SUOT.doc (08.08.2017) (in Russian).

16. STO RZhD 15.014-2012. Sistema upravleniya okhranoi truda v OAO «RZhD». Organizatsiya kontrolya i poryadok ego provedeniya: standart OAO «RZhD» [STORR 15.014-2012. Labor protection system in RR PLC. How surveillance is organized and performed: PLC RR PLC Standard]. Available at: http://docs.cntd.ru/document/1200102122 (08.08.2017) (in Russian).

17. Ul'yanov V.A. Analiz avariinosti i proizvodstvennogo travmatizma na OPO i faktory, vliyayushchie na sostoyanie bezopasnosti truda personala [Analysis of accidence and occupational traumatism at hazardous industrial objects and factors influencing staff labor safety]. Chelovek i trud, 2012, no. 6, pp. 47-51(in Russian).

18. Vil'k M.F., Ovechkina Zh.V., Sosnova T.L., Yudaeva O.S., Bukhareva E.A. Uchityvat' potrebnosti i osobennosti vsekh kategorii invalidov [To allow for needs and peculiarities of all disabled people]. Zheleznodorozhnyi transport, 2011, no. 6, pp. 30-31(in Russian).

Vil'k M.F., Yudaeva O.S., Aksenov V.A., Ponomarev V.M., Apattsev V.I., Sorokina E.A., Prostomolotova V.B., Kozlov A.S., Latynin E.O. Analysis of hazardous work environment factors at a train conductor workplace. Health Risk Analysis, 2017, no. 4, pp. 97-107. DOI: 10.21668/health.risk/2017.4.11.eng

Received: 14.09.2017

Accepted: 19.12.2017

Published: 30.12 .2017 


\title{
EXPERIMENTAL MODELS AND INSTRUMENTAL SURVEYS FOR RISK ASSESSMENT IN HYGIENE AND EPIDEMIOLOGY
}

UDC $613.6+665.71$

DOI: $10.21668 /$ health.risk/2017.4.12.eng

\section{CHANGES IN THE NERVOUS SYSTEM STATE AND PERIPHERAL BLOOD PARAMETERS UNDER BENZENE INTOXICATION DURING AN EXPERIMENT}

\author{
R.A. Orujov, R.E. Dzhafarova \\ Azerbaijan Medical University, 23 Bakikhanova Str., Baku, AZ1022, Azerbaijan
}

\begin{abstract}
Benzene is a widely spread chemical health risk factor. Our research goal was to examine the nervous system state and the blood system state under benzene intoxication during an experiment. An acute experiment was performed on 45 white mice with 5-fold poisoning with benzene; a chronic one was performed on 72 rabbits being under inhalation exposure to benzene during 4 months, its concentrations increasing and fluctuating. We determined the following blood parameters: number of reticulocytes, eosinophils, basocytes, and erythrocytes; erythrocytes sedimentation rate; blood clotting period; blood clot retraction; plasma re-calcification period; plasma tolerance to heparin; prothrombin time; prothrombin index; fibrinogen concentration; blood fibrinolytic activity; acetylcholine and choline esterase contents. We also determined adrenalin, noradrenalin, dopamine, and dihydroxyphenylalanine contents in urine.

Acute experiments results revealed that one-time exposure to benzene exerted a narcotic effect on the central nervous system which had an excitation phase and inhibition phase. Under a repeat exposure to benzene animals' drug intoxication was shorter. And here neutrophils / leucocytes gradient first increased to $139.5 \%$ from its standards value and then when down under consequent intoxications.

We detected relevant changes in morphological picture of animals' peripheral blood and their central and vegetative nervous system under chronic exposure to intermittent and increasing benzene concentrations.

So, our research revealed that effects exerted by benzene in small concentrations led to apparent shifts in white blood and catecholamines (adrenalin, noradrenalin, dopamine, and dihydroxyphenylalanine). We also detected certain signs that catecholamines endogenous reserves (dihydroxyphenylalanine) were depleted and, and also signs of eosinophils-basocytes dissociation; such prognostic signs were considered to be unfavorable as it was exactly at that moment of time (the 4th month of poisoning) when substantial changes (leucopenia, granulopenia, lymphopenia, and monocytopenia) occurred in blood. Fluctuating benzene concentrations exerted more apparent toxic effects in comparison with simply increasing toxicant concentrations.
\end{abstract}

Key words: benzene poisoning, intoxication, nervous system, drug intoxication, hemogram, catecholamines, acetylcholine, choline esterase.

Oil-refinery and petrochemical plants produced by petrochemical industry. Bentend to have a lot of potentially hazardous zene is the most toxic substance $[5,10]$. It chemicals in working areas air; these exerts effects close to those of drugs on the chemicals are chemical risk factors both central nervous system (CNS) when it is in for workers employed at these enterprises high concentrations; and it can become a and population in general $[12,15]$.

Petrol, acetone and benzene are the most widely used chemicals among those poison for blood and blood-making organs when it is introduced chronically in low doses $[13,14,17]$. It is also known, that,

(C) Orujov R.A., Dzhafarova R.E., 2017

Ragim A. Orujov - Candidate of Medical Sciences, Associate Professor at Children and Teenagers Hygiene and Occupational Hygiene Department (e-mail: rjafarova@bk.ru; tel.: +9 (9450) 551-68-32).

Rena E. Dzhafarova - Doctor of Medical Sciences, Head of the Department of Toxicology of the Scientific Research Center (e-mail: renaenver@gmail.com; tel.: +9 (9412) 594-54-16). 
depending on concentrations penetrating a body, benzene can cause various pathological reactions. And clinical signs can be absent during a long period of time but impacts exerted by benzene on a body are truly dangerous in terms of long-term effects as they can lead to leucosis, genetic disorders, and depletion of overall adaptive and protective responses complex $[12,15]$.

Nowadays, a correlation between the leukocytic reaction and neurohumoral and endocrine changes in a body is established $[9,14]$. Thus, when the sympathetic nervous system is excited, leukocytes, eosinophils, and neutrophils grow in number; and when adaptive adrenal cortex hormones are active, eosinophils number drops by $50 \%$ or more $[4,9]$. It is considered to be correct to make judgments on mineral corticoids activity as per value of neutrophils to leukocytes ratio $[9,17]$.

Allowing for this strong correlation between the neuro-endocrine system state and the peripheral blood, we set our research goal: to examine a state of these two systems under an acute and chronic intoxication with benzene

Data and methods. We performed acute and chronic experiments on two groups of laboratory animals (white mice and rabbits).

An acute experiment was performed on 45 non-linear white mice grown in the vivarium of the Scientific Research Center at Azerbaijan Medical University. Animals weighed 18-22 grams and were divided into 2 groups: the first one was intact animals, the second underwent inhalation poisoning with benzene with repeating 2-day breaks.

72 rabbits of "chinchilla" species underwent chronic benzene poisoning. The intoxication was done daily during 4 months, 4 hours a day with one day a week which was free from it, and there was 1month recovery period after the poisoning was over. Average poisoning benzene concentration in chambers was equal to $1240 \pm 82 \mathrm{mg} / \mathrm{m} 3$. The experimental animals were divided into 3 groups: group 1 was poisoned with growing benzene concentrations, group 2 was exposed to intermittent concentrations, and group 3 was a reference one, without any exposure to benzene.

We applied benzene PFA (pure for analysis) as our poisoning substance (State Standard 5055-75) ${ }^{1}$. Benzene concentrations in poisoning chambers were checked regularly via air analysis. Air in chambers was constantly mixed via ventilation systems.

We introduced 0.25 of threshold benzene concentration each 15 minutes to achieve growing concentrations mode allowing for benzene hazardous effects threshold being equal to $2000 \mathrm{mg} / \mathrm{m}^{3}$ [13].

To achieve benzene intermittent concentrations, we introduced benzene into chambers each 30 minutes in various quantities, to make concentrations fluctuate significantly. Sometimes a chamber was open for 20 minutes ventilating. And here concentrations sequences changed every day during 12 days (Table 1), and then were repeated in the same order during 4 months.

Blood tests were taken in the morning, before feeding, from an ear border vein (rabbits) and from a caudal vein (mice). Reticulocytes number was calculated in preparations dyed with brilliant cresyl-violet via Pappenheim technique. To make chamber calculation of eosinophils, we diluted blood with a liquid offered by I.S. Piralashvili, basocytes chamber calculation was performed as per M.P. Vilchinskiy's modification [2].

${ }^{1}$ State Standard 5955-75. BENZENE reagents: The USSR State Standard. Available at: http://docs.cntd.ru/document/gost-5955-75 (08.07.2017). 
Table 1 vertebrate animals used for experimental

Animals poisoning with intermittent benzene concentrations

\begin{tabular}{|c|c|c|c|c|c|c|c|c|c|}
\hline $\begin{array}{c}\text { Poisoning } \\
\text { days }\end{array}$ & \multicolumn{8}{|c|}{$\begin{array}{c}\text { Benzene concentrations in a chamber, } \\
\text { shares from threshold }\end{array}$} \\
\hline 1 & 0,25 & 2,0 & 0 & 5,25 & 0,5 & 0 & 6,0 & 0 & 2,0 \\
\hline 2 & 5,0 & 0 & 1,75 & 0 & 4,0 & 0,25 & 0 & 4,5 & 0,5 \\
\hline 3 & 4,5 & 0,25 & 0 & 3,75 & 0 & 0,5 & 0 & 1,5 & 5,5 \\
\hline 4 & 2,0 & 0 & 4,5 & 0 & 2,5 & 0 & 5,0 & 0,25 & 1,75 \\
\hline 5 & 1,75 & 0,25 & 0 & 4,75 & 0 & 1,25 & 0 & 6,0 & 2,0 \\
\hline 6 & 1,25 & 6,0 & 0 & 0,25 & 0 & 5,5 & 0 & 2,0 & 1,0 \\
\hline 7 & 0,25 & 0 & 2,5 & 0 & 4,75 & 1,5 & 0 & 3,75 & 3,25 \\
\hline 8 & 0,5 & 1,25 & 0 & 5,75 & 0 & 2,5 & 0 & 1,5 & 4,5 \\
\hline 9 & 4,75 & 0 & 1,25 & 0 & 4,5 & 0 & 1,5 & 2,25 & 1,75 \\
\hline 10 & 2,0 & 0,25 & 0 & 6,75 & 0 & 4,0 & 0 & 0,5 & 2,5 \\
\hline 11 & 4,0 & 0 & 0,25 & 0 & 5,75 & 0,5 & 1,5 & 0 & 4,0 \\
\hline 12 & 0,25 & 4,75 & 1,0 & 0 & 3,75 & 0 & 1,25 & 0 & 5,0 \\
\hline
\end{tabular}

We also examined erythrocytes sedimentation rate and erythrocytes acid resistance. The latter was determined as per I.A. Terskov and I.I.Gitelzon technique, modificaiton by A.I. Vorobiyov [2]; acetylcholine (AC), as per S.Hestrin technique [16], choline esterase (CE), as per E.Sh.Matlin technique [7]. We applied trioxyindole fluorimetric technique for determining adrenaline (A), noradrenalin (NA), dopamine (D), and dihydroxyphenylalanine (DHPA) in a single urine portion [13]. To get insight into the blood coagulating system state, we determined blood coagulation time (BCT), blood clot retraction (BCR), plasma re-calcification time (PRT), plasma tolerance to heparin $(\mathrm{PTH})$, prothrombin time and prothrombin index, fibrinogen concentration, and blood fibrinolytic activity (FA) $[1,6]$.

Beyond experiments, all the animals were kept and fed under the same conditions. All the experiments on the animals were performed in full conformity with "European Convention for the protection of and other scientific purposes" (Strasburg, March 18, 1986) ${ }^{2}$.

We detected statistically significant discrepancies between the compared groups with Student's parametric criterion. Causeand-effect relations between exposure factors and their effects were revealed via multi-factor correlation analysis and other mathematical statistics techniques.

Results and discussion. Results obtained in acute experiments revealed that a single exposure to benzene exerted a narcotic effect on the central nervous system which was characterized with excitation and inhibition phases. A repeated exposure to benzene involved shorter periods during which animals suffered from narcotic intoxication. For example, after the 5th exposure, intoxication time decreased from $34.60 \pm 3.05$ minutes to $12.27 \pm 3.71$ minutes and it can be considered signs of adaption to benzene effects which evolved in the animals [9, 10].

Table 2

Leuko-formula elements picture under single and repeated exposure to benzene (in \% of the background taken as 100)

\begin{tabular}{|c|c|c|}
\hline \multirow[b]{2}{*}{ Leukocytes } & \multicolumn{2}{|c|}{ Exposure mode } \\
\hline & $\begin{array}{l}\text { Single expo- } \\
\text { sure }\end{array}$ & $\begin{array}{l}\text { Repeated } \\
\text { exposure }\end{array}$ \\
\hline Leukocytes & 73,70 & 86,70 \\
\hline Eosinophils & 41,20 & 60,0 \\
\hline Neutrophils & 87,60 & 98,30 \\
\hline Lymphocytes & 62,80 & 86,30 \\
\hline $\begin{array}{l}\text { Neutrophils/Leukocytes } \\
\text { (N/L) }\end{array}$ & 139,50 & 81,10 \\
\hline
\end{tabular}

Table 2 comprises data reflecting changes in a blood picture under various benzene exposure modes; as we can see from it, after narcotic effects pass, an au-

${ }^{2}$ European convention for the protection of vertebrate animals used for experimental and other scientific purposes. Strasburg, March 18, 1986. 13 p. Available at: http://docs.cntd.ru/document/gost-5955-75 (10.06.2017). 
thentic decrease in leukocytes number and their specific forms occurs. A considerable decrease in leukocytes number makes for neutrophils/leukocyte $(\mathrm{N} / \mathrm{L})$ gradient growth up to $139.5 \%$ of the background level.

We detected changes in blood components after the repeated exposure to the toxicant; these changes were different from the initial parameters before the first poisoning. There was an increase in leukocytes number with simultaneous $\mathrm{N} / \mathrm{L}$ gradient fall. Absolute number of eosinophils returned to its initial value before the first poisoning (Table 2).

A significant decrease in erythrocytes number (Figure 1) and hemoglobin was detected in the morphological picture of animals (rabbits)' peripheral blood under chronic exposure to intermittent and increasing benzene concentrations. This decrease was more significant during the first month of chronic poisoning with intermittent concentrations.
By the end of the observations period the red blood composition somehow got back to normal as erythrocytes number was close to background values and to the same parameter in animals from the reference group (it as equal to $9.20 \pm 0.30 \times 10^{12} / 1$ in the experimental animals; $10,40 \pm 0,15 \times 10^{12} / 1$, in the reference group animals; background level was equal to $\left.11,30 \pm 0,40 \times 10^{12} / 1\right)$.

The animals from this group also had a decrease in overall erythrocytes sedimentation rate which became more apparent by the end of the fourth month under chronic exposure to benzene (Figure 2).

Together with certain quantitative changes, our research revealed a number of qualitative shifts in the red blood picture, their evidence being changes in erythrocytes acid resistance which can be seen in acid erythrograms deviations to the right. These changes appeared at the end of the second month and it proved young and more acid-resistant erythrocytes occurred in the peripheral blood.

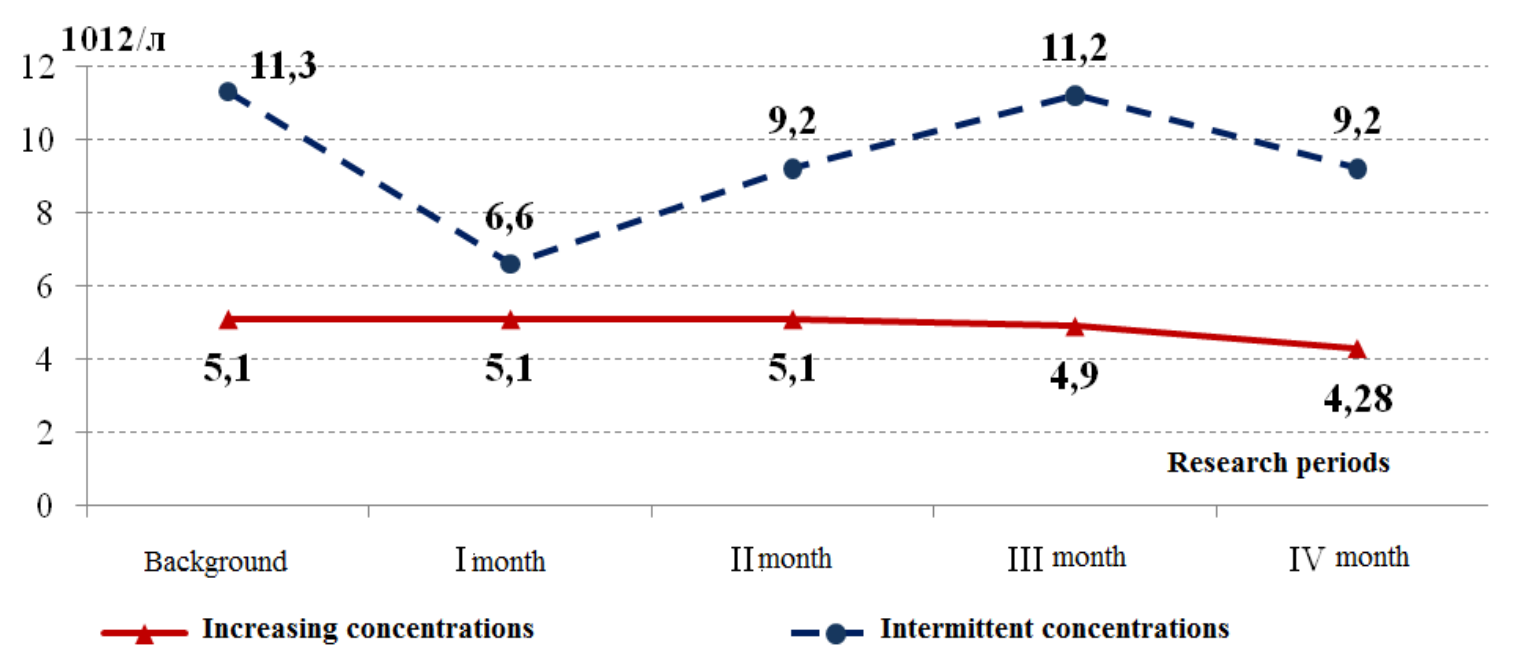

Figure 1. Dynamics of erythrocytes number changes in animals' peripheral blood under various modes of exposure to small benzene concentrations.

(Parameters are authentic against the reference group $(\mathrm{p}<0.01)$ 


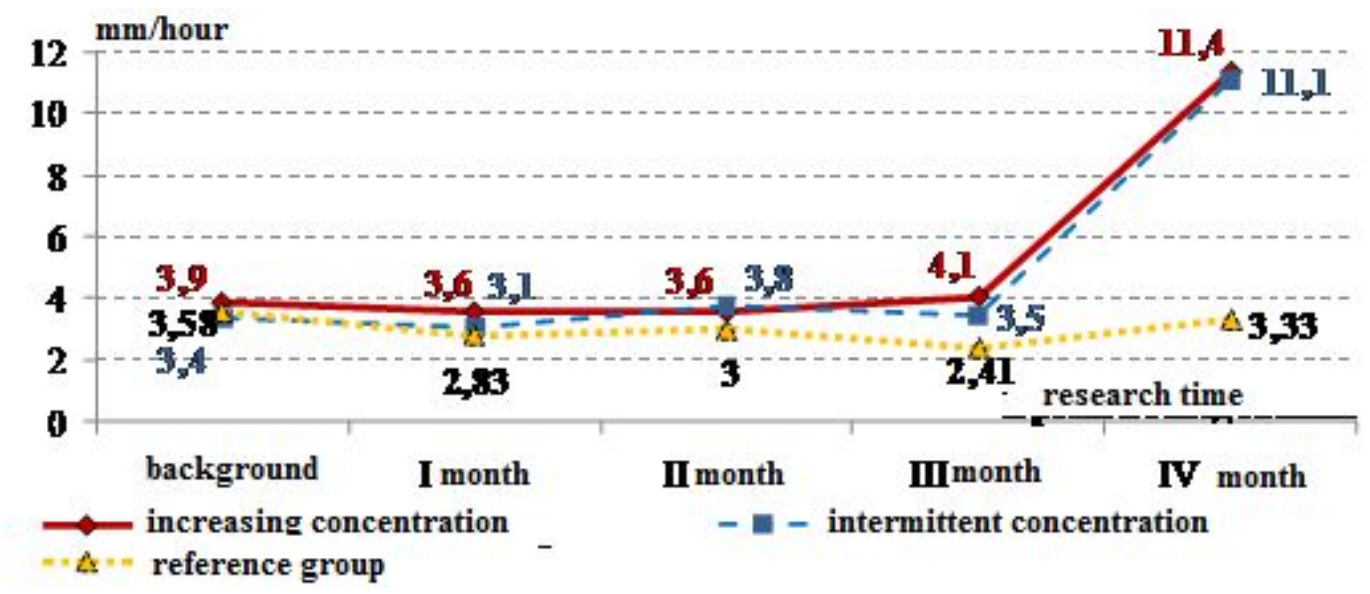

Figure 2. Dynamics of changes in overall erythrocytes sedimentation rate in animals' peripheral blood under chronic inhalation poisoning with benzene

(The parameters are authentic against the reference group $(p<0.05)$

As we can see from Table 3, a month animals' exposure to benzene caused a $61.8 \%$ decrease in eosinophils/basocytes gradient due to a drastic growth in basocytes number $(187.70 \%, \mathrm{p}<0.01)$, while eosinophils number increased only slightly $(107.70 \%, \mathrm{p}<0.05)$.

Table 3

Dynamics in blood coagulation system pa-

rameters and eosinophils/basocytes association

\begin{tabular}{|l|c|c|c|c|}
\hline \multirow{1}{*}{ Parameters } & \multicolumn{4}{|c|}{$\begin{array}{c}\text { Research periods and } \\
\text { parameters values } \\
\text { (in \% from the initial level) }\end{array}$} \\
\cline { 2 - 5 } & $\begin{array}{c}\text { I } \\
\text { month }\end{array}$ & $\begin{array}{c}\text { II } \\
\text { month }\end{array}$ & $\begin{array}{c}\text { III } \\
\text { month }\end{array}$ & $\begin{array}{c}\text { IV } \\
\text { month }\end{array}$ \\
\hline Eosinophils/basocyte & 61,80 & 110,20 & 100,0 & 112,40 \\
\hline Blood clot retraction & $123,1^{*}$ & $128,4^{*}$ & $140,4^{*}$ & $140,0^{*}$ \\
\hline $\begin{array}{l}\text { Blood coagulation } \\
\text { time }\end{array}$ & 112,70 & $125,50^{*}$ & $144,50^{*}$ & $147,50^{*}$ \\
\hline $\begin{array}{l}\text { Plasma re- } \\
\text { calcification time }\end{array}$ & 109,30 & 101,20 & 107,60 & 106,70 \\
\hline Prothrombin time & 04,50 & 94,0 & $97,80^{*}$ & 94,0 \\
\hline Prothrombin index & 94,10 & 102,30 & 99,30 & 101,20 \\
\hline $\begin{array}{l}\text { Plasma tolerance to } \\
\text { heparin }\end{array}$ & 115,40 & 97,60 & $145,9^{*}$ & $178,8^{*}$ \\
\hline
\end{tabular}

Note: *-means these parameters are authentically different from the reference group $(p<0,02)$.

The above-mentioned changes were mostly accompanied with blood clot retrac- tion growth $(123.1 \%, \mathrm{p}<0.02)$. We also observed a trend for longer blood coagulation time $(112.7 \%, \mathrm{p}<0.02)$ and plasma recalcification time $(109.3 \%, \mathrm{p}<0.02)$.During the subsequent experimental months, there was a gradual growth in blood coagulation time $(125.50-147.50 \%, \mathrm{p}<0.001)$ and blood clot retraction (128.4-140.0\%, $<<0.01)$, but plasma tolerance to heparin increased only after 3 months $(145.9 \%-178.8 \%, \mathrm{p}<0.02)$ (Table 3). These data prove that blood anticoagulation properties grow steadily. But still, we didn't detect any bleeding which was specific for benzene, given all the detected changes in the blood coagulation system; absence of eosinophils-basocytes dissociation fully corresponds to the situation. The latter can be explained by a growth in eosinophils number.

The biggest deviations in leukocytes number from the initial value occurred during the second month of exposure to increased benzene concentrations; the number grew from 9.95 to $13.08 \times 10^{3} \mu$ l (Figure 3 ). By the end of the 4th month of poisoning leukocytes number decreased to $5.95 \pm 0.49$ $\mathrm{x} 10^{3} \mu \mathrm{l}$. 


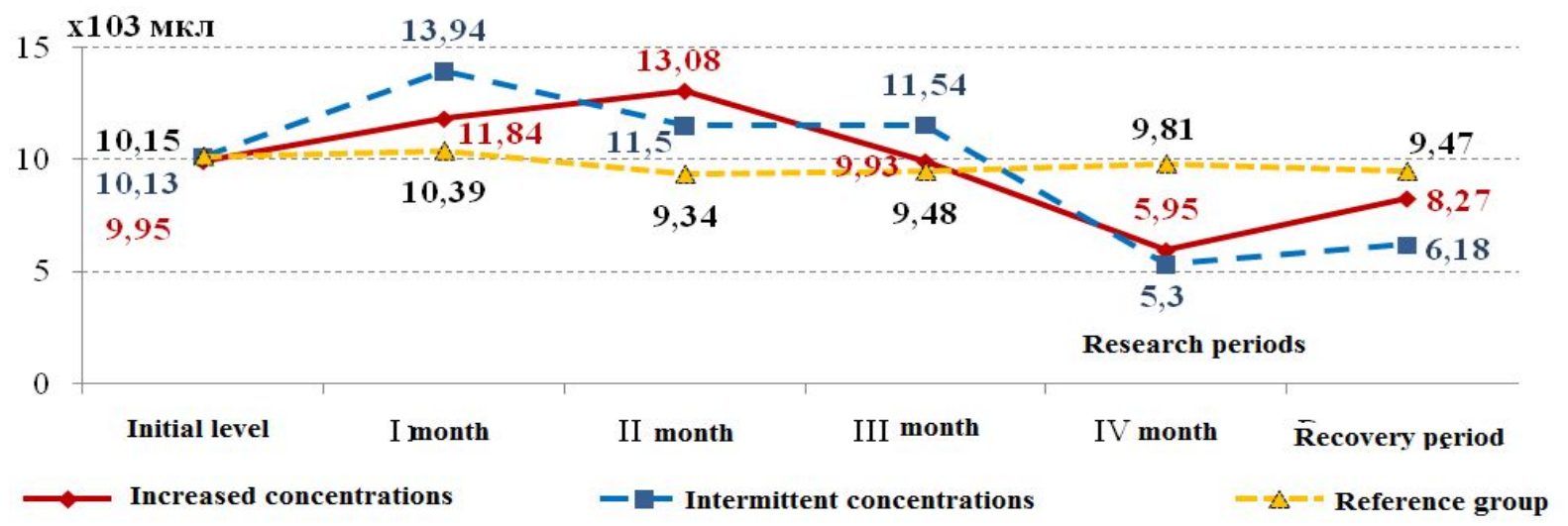

Figure 3. Dynamics of changes in animals' leukocytes in peripheral blood exposed to chronic benzene poisoning (The parameters are authentic against the reference group $(p<0.01)$

The parameters recovered up to their initial level during a month after poisoning stopped; it proves that all the occurred changes are reversible.

Shifts in leukocytic formula of the animals from the second group were more apparent. Thus, wave-like changes in leukocytes and their specific elements content under exposure to benzene in intermittent concentrations were accompanied with a growth in leukocytes number during the first month of poisoning (from 10.13 to $13.94 \times 10^{3}$ $\mu 1)$. By the end of the observations we detected a significant decrease in leukocytes number in the experimental rabbits $\left(5.30 \times 10^{3} \mu 1\right)$. We should note that statistically authentic low leukocytes level (against the reference one) at the end of a monthly recovery period (initial level was $10.13 \pm 0.60 \times 10^{3} \mu 1$, level during a recovery period was $6.18 \pm 0.73 \times 10^{3} \mu \mathrm{l}$ ) can be an evidence that animals body reactivity decreased considerably under exposure to intermittent benzene concentrations.

Changes in leukocytic formula parameters occurred at the end of the first month of poisoning. These changes were an increase in neutrophils number (neutrophilic leukocytosis with a shift to the left), as well as lymphocytosis and monocytosis. By the end of the poisoning period shifts in leukocytic formula of experimental ani- mals were quite the opposite: we detected absolute neutropenia, lymphocytopenia, and monocytopenia. 1 months after, when the animals no longer contacted benzene, we didn't detect full recovery in the parameters (they didn't return to their initial levels) and it could be an evidence that a recovery period was too short, or body reactivity decreased too significantly.

So, we examined leukocytic reaction which occurred in the experimental animals as a response to benzene impacts under various intoxications modes; our examination revealed that intermittent benzene concentrations exerted more apparent impacts in comparison with growing toxicant concentrations mode. Thus, authentic decrease in leukocytes number which corresponds to the 3rd and 4th months of poisoning under both intoxication modes didn't disappear in those animals which were exposed to intermittent benzene concentrations. Consequently, concentrations which fluctuated during poisoning caused more considerable changes in animals' bodies and it resulted in adaptation mechanisms depletion.

The results we obtained during our experimental research were analyzed as per catecholamines metabolism and the acetylcholine - choline esterase system. We de- 
tected that reactive changes in the sympathoadrenal system are characterized with a certain activity of catecholamines biosynthesis, secretion, elimination, and metabolism, which varies in different periods of exposure to intermittent benzene concentrations. The first stage in the reaction occurred during the 1 st experimental month and was characterized with a synchronous sympathoadrenal system (SAS) activation when adrenaline, noradrenalin, dopamine, and DHPA excretion with urine grew (Figure 4). Sympathetic nervous system activity in experimental rabbits grew more substantially at this stage as noradrenalin quantity (noradrenalin being a basic sympathetic nervous system mediator) grew faster than that of adrenaline and it led to a relative decrease in $\mathrm{A} / \mathrm{NA}$ ratio.

By the end of the exposure period we detected the second stage in the reaction which could be determined as secretorysympathetic activity dissociation phase. Here we detected a further growth in NA concentration, certain relative decrease in adrenalin, dopamine, and DHPA level in urine.

SAS reserves and precursors level in urine increased initially at the first stage but them at the second one we observed signs of DHPA (endogenous catecholamine reserve) depletion (Figure 4).

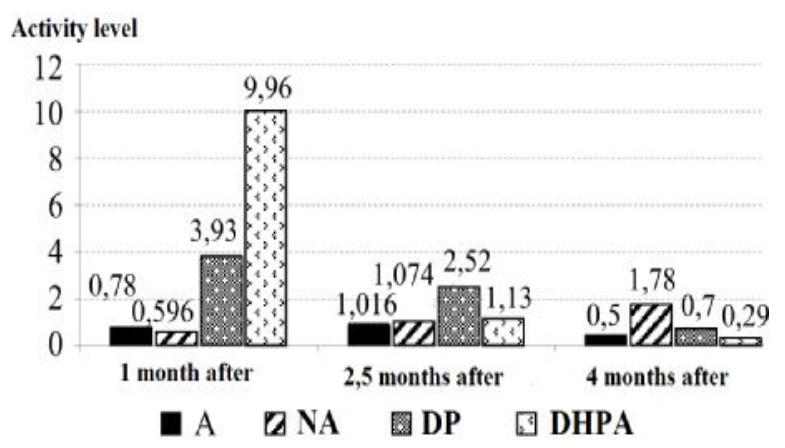

Figure 4. Contents of catecholamines and their precursors in daily rabbits' urine under chronic exposure to intermittent benzene concentrations ( $\mathrm{A}$ is adrenaline, NA is noradrenalin, DP is dopamine, DHPA is dihydroxyphenylalanine)

Table 4

Acetylcholine content and choline esterase activity in rabbits exposed

to small benzene concentrations

\begin{tabular}{|c|c|c|c|c|}
\hline $\begin{array}{c}\text { Animals groups and poi- } \\
\text { soning modes }\end{array}$ & $\begin{array}{c}\text { Observation periods, } \\
\text { months }\end{array}$ & \multicolumn{3}{|c|}{ Examined parameters and their values } \\
\cline { 2 - 5 } & In $\mu \mathrm{g} \%$ & $\mathrm{IC}, \mu \mathrm{g} / \mathrm{min}$ & $\mathrm{LC}, \mu \mathrm{g} / \mathrm{min}$ \\
\hline \multirow{4}{*}{\begin{tabular}{c} 
I. Increased concentrations \\
\cline { 2 - 4 }
\end{tabular}} & 1 month after & $0,33 \pm 0,04$ & $0,66 \pm 0,06$ & $0,38 \pm 0,10$ \\
\cline { 2 - 5 } & 2 months after & $0,46 \pm 0,03$ & $0,92 \pm 0,03$ & $0,32 \pm 0,02$ \\
\cline { 2 - 5 } & 3 months after & $0,49 \pm 0,03$ & $0,98 \pm 0,04$ & $0,20 \pm 0,01$ \\
\cline { 2 - 5 } & 4 months after & $0,40 \pm 0,02$ & $0,99 \pm 0,08$ & $0,19 \pm 0,01$ \\
\hline \multirow{4}{*}{$\begin{array}{c}\text { II. Intermittent concentra- } \\
\text { tions }\end{array}$} & Initial level (background) & $0,22 \pm 0,03$ & $0,94 \pm 0,14$ & $0,28 \pm 0,04$ \\
\cline { 2 - 5 } & 1 month after & $0,34 \pm 0,05$ & $0,69 \pm 0,09$ & $0,44 \pm 0,12$ \\
\cline { 2 - 5 } & 2 months after & $0,50 \pm 0,06$ & $1,14 \pm 0,04$ & $0,32 \pm 0,02$ \\
\cline { 2 - 5 } & 3 months after & $0,51 \pm 0,04$ & $1,26 \pm 0,08$ & $0,21 \pm 0,01$ \\
\cline { 2 - 5 } & 4 months after & $0,46 \pm 0,04$ & $1,08 \pm 0,12$ & $0,18 \pm 0,01$ \\
\hline \multirow{5}{*}{ Reference } & Initial level (background) & $0,21 \pm 0,01$ & $0,87 \pm 0,07$ & $0,27 \pm 0,03$ \\
\cline { 2 - 5 } & 1 month after & $0,22 \pm 0,02$ & $0,89 \pm 0,08$ & $0,26 \pm 0,03$ \\
\cline { 2 - 5 } & 2 months after & $0,20 \pm 0,02$ & $0,93 \pm 0,03$ & $0,27 \pm 0,03$ \\
\cline { 2 - 5 } & 3 months after & $0,22 \pm 0,02$ & $0,90 \pm 0,04$ & $0,26 \pm 0,04$ \\
\cline { 2 - 5 } & 4 months after & $0,21 \pm 0,02$ & $0,87 \pm 0,04$ & $0,25 \pm 0,03$ \\
\hline
\end{tabular}


We determined parasympathetic nervous system activity simultaneously with sympathetic nervous system activity as these two systems are interconnected. Parasympathetic nervous system activity became apparent through increase in acetylcholine concentration in blood, higher acetylcholine esterase and lower butyrylcholine esterase. By the end of the observation period butyrylcholine esterase activity fell but acetylcholine (AC) level still remained high (Table 4).

Our research results and other authors' works $[8,12,13,17]$ reveal that a primary body reaction to toxic effects exerted by benzene appears in the peripheral blood system which, in its turn, gives information on the sympathetic nervous system state. So, a primary body reaction to endogenous irritation can be seen in the sympathetic nervous system excitation with a corresponding increase in blood sympathetic activity. This primary increase in blood sympathetic activity gives an impulse to a compensatory reac- tion of the parasympathetic nervous system and other corrective systems $[9,15]$.

So, impacts exerted by benzene in small concentrations caused changes in some regulatory systems of experimental animals' bodies. The most apparent and earliest shifts were detected in the white blood and catecholamines (adrenaline, noradrenalin, dopamine, and DHPA). The detected signs of catecholamines and DHPA endogenous reserves depletion as well as eosinophilsbasocyte dissociation are unfavorable as it is exactly at this period (the 4th poisoning month) when significant changes in blood occur, namely leucopenia, neutropenia, lymph- and monocytopenia. And here intermittent benzene concentrations exert more apparent toxic effects in comparison with growing toxicant concentrations. Leukocytes quantity which decreased during the $3 \mathrm{rd}$ and 4th poisoning months didn't recover to its initial levels during a recovery period in animals who were exposed to intermittent benzene concentrations.

\section{References}

1. Balandina A.N., Panteleev M.A., Ataullakhanov F.I. Sistema svertyvaniya krovi I ee regulyatsiya [Blood clotting system and its regulation]. Priroda, 2011, no. 3, pp. 32-38 (in Russian).

2. Vil'chinskii M.P. Uproshchennaya metodika izbiratel'noi okraski bazofil'nykh granulotsitov krovi [Simplified methodology for selective stain of blood basocyte granulocytes]. Laboratornoe delo, 1972, no. 1, pp. 58-59 (in Russian).

3. Vorob'ev A.I. Izuchenie kislotoustoichivosti eritrotsitov $\mathrm{v}$ gematologicheskoi klinike [Examination of erythrocytes resistance to acid in a hematological clinic]. Aktual'nye voprosy gematologii, 1960, no. 2, pp. 314-316 (in Russian).

4. Zyubina L.Yu., Shpagina L.A., Panacheva L.A. Professional'no obuslovlennye gemopatii i professional'nye zabolevaniya krovi [Industrially mediated hemopathies and occupational diseases of blood]. Meditsinatruda i promyshlennayaekologiya, 2008, no. 11, pp. 15-20 (in Russian).

5. Kutsenko S.A. Osnovy toksikologii [Basics of toxicology]. St. Petersburg, 2004, 570 p. (in Russian).

6. Bokarev I.N., Doronina A.M., Kozlova T.V. [et al.]. Laboratornye metody issledovaniya sistemy svertyvaniya krovi: metodicheskie rekomendatsii [Laboratory techniques for blood clot- 
ting system examination: methodical guidelines]. Moscow, ATGPSS, Publ., 2011, 15 p. (in Russian).

7. Matlina E.Sh., Prikhozhan V.M. K metodike opredeleniya kholinesterazy v krovi [On methodology for choline esterase detection in blood]. Laboratornoe delo, 1961, no. 6, pp. 10-12 (in Russian).

8. Mikhailova I.V. Otsenka vozdeistviya benzola i khroma na faktory estestvennoi rezistentnosti $\mathrm{v}$ eksperimente [Impact assessment of benzene and chrome on the natural resistance factors in the experiment]. Rossiiskii immunologicheskii zhurnal, 2014, vol. 8, no. 3 (17), pp. 454-457 (in Russian).

9. Orujov R.A. Nekotorye pokazateli adaptatsionnykh sdvigov organizma pri povtornykh ostrykh intoksikatsiyakh uglevodorodami [Specific parameters of adaptation shifts in a body under repeat acute intoxications with hydrocarbons]. Zdorov'e, 2014, no. 3, pp.112-117 (in Russian).

10. Orujov R.A. Razlichie v deistvii promyshlennykh narkotikov na primere benzola, benzina $\mathrm{i}$ atsetona [Differences in effects exerted by industrial drugs on the examples of benzene, petrol, and acetone]. Azmedzhurnal, 2014, no. 2, pp. 95-98 (in Russian).

11. Piralashvili I.S. K metodike podscheta eozinofilov v perifericheskoi krovi [On methodology for calculating eosinophils in peripheral blood]. Laboratornoe delo, 1962, no. 3, pp. 20-22 (in Russian).

12. Yang J., Bai W.n, Niu P., Tian L., Gao A. Aberrant hypomethylated STAT3 was identified as a biomarker of chronic benzene poisoning through integrating DNA methylation and mRNA expression data. Experimental and Molecular Pathology, 2014, vol. 96, no. 3, pp. 346353.

13. Wen H., Yuan L., Wei C., Zhao Y., Qian Y., Ma P., Ding S., Yang X., Wang X. Effects of combined exposure to formaldehyde and benzene on immune cells in the blood and spleen in Balb/c mice. Environmental Toxicology and Pharmacology, 2016, vol. 45, pp. 265273.

14. Hestrin $\mathrm{S}$. The relation acetylcholine and other carbocholine acidi derivatwes with hydroxylamine and its analytical application. J. biol. Chem, 1949, vol.180, no.1, pp. 249-251.

15. Kerzic P.J. [et al.]. Analysis of hydroquinone and catechol in peripheral blood of benzene-exposed workers. Chemico-Biological Interactions, 2010, vol. 184, pp. 182-188.

16. Geering B., Stoeckle Ch.., Conus S., Hans-Uwe S. Living and dying for inflammation: neutrophils, eosinophils, basophils. Trends in Immunology, 2013, vol. 34, no. 8, pp. 398-409.

17. Rizzo M. [et al.]. Cortisol levels and leukocyte population values in transported and exercised horses after acupuncture needle stimulation. Journal of Veterinary Behavior: Clinical Applications and Research, 2017, vol. 18, pp. 56-61.

Orujov R.A., Dzhafarova R.E. Changes in the nervous system state and peripheral blood parameters under benzene intoxication during an experiment. Health Risk Analysis, 2017, no. 4, pp. 108-116. DOI: 10.21668/health.risk/2017.4.12.eng

Received: 11.07.2017

Accepted: 18.12.2017

Published: 30.12 .2017 
UDC 51-76

DOI: 10.21668/health.risk/2017.4.13.eng

\title{
MATHEMATICAL MODEL FOR DESCRIBING ANTI-VIRUS IMMUNE RESPONSE REGULATION ALLOWING FOR FUNCTIONAL DISORDERS IN A BODY*
}

\author{
P.V. Trusov ${ }^{1,2}$, N.V. Zaitseva ${ }^{1}$, V.M. Chigvintsev ${ }^{1,2}$, D.V. Lanin ${ }^{1,3}$ \\ ${ }^{1}$ Federal Scientific Center for Medical and Preventive Health Risk Management Technologies, 82 Monastyrskaya \\ Str., Perm, 614045, Russian Federation \\ ${ }^{2}$ Perm National Research Polytechnic University, 29 Komsomolskiy avenue, Perm, 614990, Russian Federation \\ ${ }^{3}$ Perm State University, 15 Bukireva Str., Perm, 614990, Russian Federation
}

Our task was to create a mathematical model which could describe anti-virus immune response regulation allowing for disorders in the adaptation (neuroendocrine and immune) systems caused by chemical factors of various genesis. We analyzed immune response allowing for immunity types (inborn and acquired one) with certain quantitative parameters chosen in order to characterize them, notably: interferon and NK-cells for inborn immunity, and virus-specific cytotoxic T-cells and antibodies-forming B-lymphocytes for acquired immunity. Regulatory mechanisms incorporated in the model comprise influences exerted by hypothalamushypophysis-adrenals system hormones (corticoliberin, adrenocorticotropic hormone, and hydrocortisone), and cytokines (interleukin-1 and interleukin-2) produced by various regulatory cells of the immune system. The suggested model also takes spatial organization of infection and immune processes in different organs and tissues into account as we introduced a time lag for components interaction into it.

The model includes a system of 18 ordinary differential equations with a retarded argument; its parameters characterize how fast various processes influencing an infection dynamics evolve in a body. The parameters are identified on the basis of published experimental data which describe a process of a body being infected with a virus. We calculated dynamics in the immune and neuroendocrine system parameters under a virus infection allowing for disorders in the marrow synthetic function. The model is developed within the framework of a concept viewing a human body as a multi-level model allowing for interactions between its systems and functional state of examined organs under influences exerted on them by hazardous factors of different genesis. The performed research gives a qualitative idea on biological factors which explain an infectious agent kinetics under a virus infection and impacts exerted by factors of various genesis. The results can be applied for adjusting parameters of existing population models, spread and clinical course of various infections, and for making long-term forecasts on an epidemiologic situation which is necessary when we analyze infectious diseases risks, including those which occur under impacts exerted on a human body by hazardous environmental factors.

Key words: mathematical model, dynamic system, virus disease, inborn immunity, acquired immunity, neuroendocrine regulation.

Nowadays an issue of describing inter- their functioning in order to preserve their relations in adaptive systems which change optimal state under changing conditions is

(C) Trusov P.V., Zaitseva N.V., Chigvintsev V.M., Lanin D.V., 2017

Petr V. Trusov - Doctor of Physical and Mathematical Sciences, Professor, Head of Mathematic Modeling of Systems and Processes Department, Chief Researcher (e-mail: tpv@matmod.pstu.ac.ru, tel.: +7 (342) 239-16-07).

Nina V. Zaitseva - Member of the Russian Academy of Sciences, Doctor of Medical Sciences, Professor, Director (e-mail: znv@,fcrisk.ru; tel.: +7 (342) 237-25-34).

Dmitrii V. Lanin - Doctor of Medical Sciences, Associate Professor, Leading Researcher at Immune Biological Diagnostic Techniques Department, Professor at Human Ecology and Life Safety Department (e-mail: dmlan@fcrisk.ru; tel.: +7 (342) 237-18-04).

Vladimir M. Chigvintsev - Researcher at Mathematic Modeling of Systems and Processes Department, post-graduate student at Mathematic Modeling of Systems and Processes Department (e-mail: cvm@fcrisk.ru; tel.: +7 (342) 237-18-04).

* The research was performed duevti funancial support by RFBR within the scientific project No 16-31-00333 mol_a. 
of great interest to researchers both in the sphere of neuroendocrine regulation and immune mechanisms $[25,30]$. Works published in the field focus on various sings of mutual regulatory influences [17, 41]. Some research dwells on neuroendocrine regulation of the immune system [4, 19, 29] and controlling influence exerted by the immune system, for example, via cytokines production, both on itself and on the neuroendocrine regulatory loop [37, 41]. Most experts believe neuroendocrine and immune regulatory loops are a unified "super"-regulatory meta-system $\quad[9,21]$, which coordinates a complicated multi-level controlling process in a living system. The immune system is responsible for various mechanisms aimed at a macro-organism protection, including those preventing from virus infections. Losses occurring due to infectious morbidity make a considerable contribution into overall damages done to population by various health disorders and are a great medical and social problem [44]. Thus, morbidity with children virus infections (measles, chicken pox, and rubella) is significant among children population [12]. Acute respiratory virus infections in the RF take the first place among reasons for a temporary disability among adult population. Increased morbidity with virus hepatitis [11], HIV-infection [1], etc. is another serious problem.

Technogenic environmental factors can cause pathomorphism and lead to deterioration of infectious diseases clinical course and outcome $[8,10,12,13]$. Technogenic processes exert influence on regulatory (immune and neuroendocrine) systems; thus, for example, it was shown [3], that technogenic chemical factors exerted negative impacts on the said systems functioning.

Observation techniques or an experimental approach which are conventionally applied in biology and medicine to assess functional disorders in the immune and neuroendocrine system usually involve consequent statistical processing of the results. In spite of all their significance, they don't fully allow to analyze mechanisms and assess consequences caused by an effect occurring when functional disorders accumulate in body systems. It is due to limitations which exist in choice of representative groups, complications related to identification and detection of basic factors, and substantial material costs which are required for organizing and conducting experiments.

Mathematical modeling seems to be one of the most efficient approaches to finding an optimal strategy for examining as well as predicting clinical course of virus diseases. To study regulatory systems influences, we previously suggested to apply a mathematical model of interaction between the immune and neuroendocrine system which we developed on the example of a bacterial infection [14]. This approach allows to save time and resources required for solving the set tasks. Mathematical models make it possible to analyze influence exerted by various factors and their combinations on an individual and population level. An example of such models is mathematical prediction models which describe correlation between human health and environmental factors [7].

Our research goal was to give a mathematical description of an interaction between the immune and neuroendocrine systems mechanisms which occurs under a virus infection; this description allowed for functional disorders caused by negative influences exerted by chemical environmental factors.

Data and methods. Structural scheme of our model given in Figure 1 is a set of interrelated immune and neuroendocrine system elements which are the most significant components in a body response to a virus invasion. The model allows for func- 
tional state of organs which are being considered. We can highlight such factors influencing changes in their state as natural ageing and negative impacts exerted by various chemicals penetrating a body from the environment.

As we describe interactions between the immune and endocrine system which are very complicated we introduce certain simplifying assumptions into the design of our model. Cells and viruses populations are assumed to be evenly spread over the epithelial layer of a target organ at any moment. We also assume that speed of changes in any variable in the model is determined by the current values of all the variables. At present we assume that the basic processes which regulate immune protection dynamics take place in three local volumes: brains (hypophysis and hypothalamus), abdominal cavity (adrenals), and a target organ. Interaction between these three local volumes occurs with a time lag.

Protection mechanisms are activated after macrophages have started interaction with dead cells of a target organ which were destroyed due to a virus life cycle. As macrophages remove cells damaged by a virus, simultaneously information molecules of (cytokine) interleukin-1 are synthesized [22].

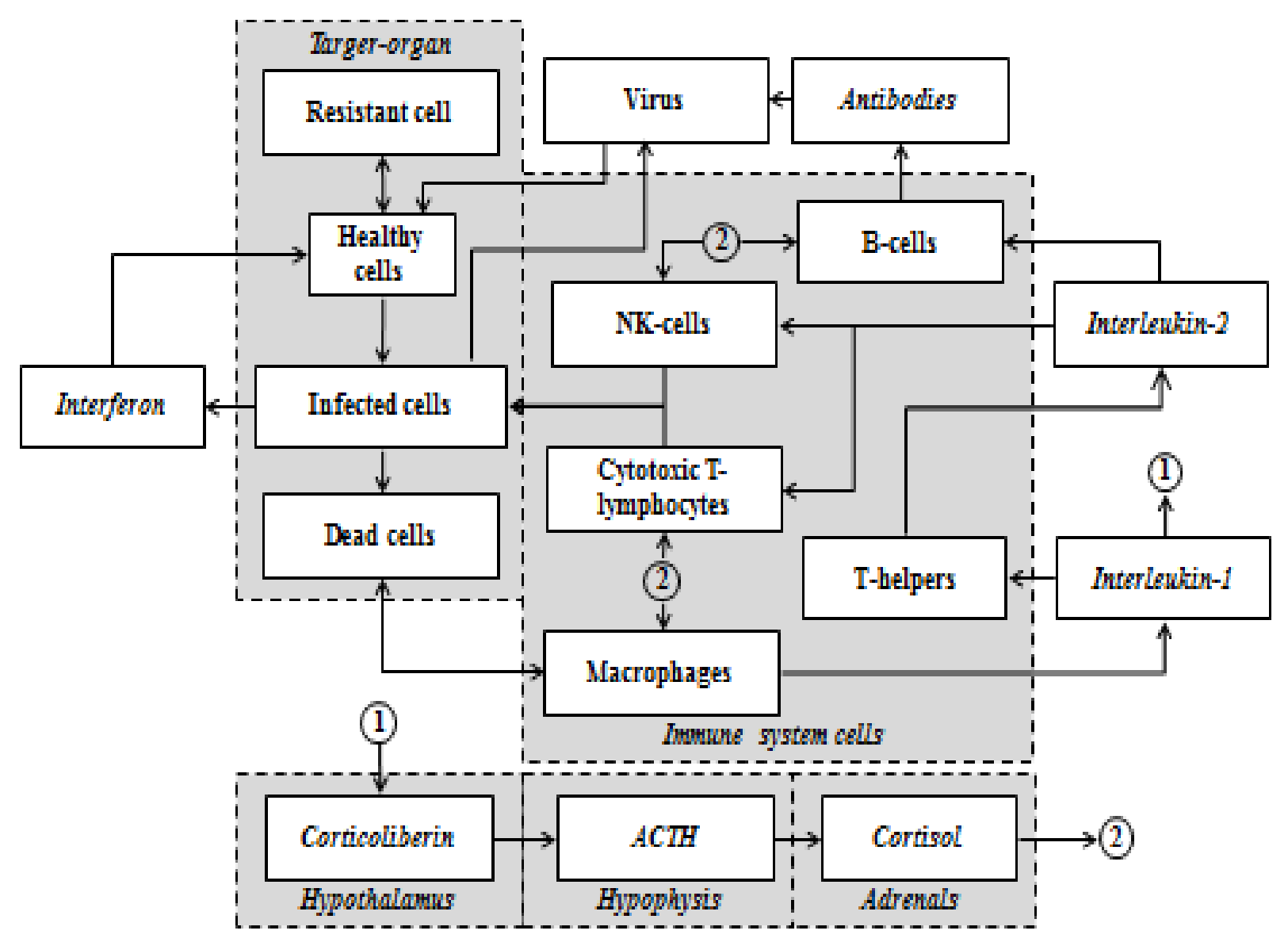

Figure 1. Immune and neuroendocrine system functioning in case virus infection occurs: a conceptual scheme 
As interleukin-1 concentration in blood increases, it makes for T-helpers producing interleukin-2 and stimulates specific receptors in the hypothalamus to produce corticoliberin, a release hormone. Corticoliberin influences the adenohypophysis and causes adrenocorticotropic hormone (ACTH) secretion [18], When penetrating blood, ACTH stimulates the adrenals to produce hydrocortisone; increased concentration of this hormone inhibits ACTH secretions and blocks interleukin-1 production as per negative feedback mechanism.

Regulatory impacts exerted by interleukin2 are aimed at NK-cells cytotoxic Tlymphocytes and B-cells [15, 32, 35]. Basic NK-cells function is related to infected cells elimination at early stages of a body protecting against virus infections. NKcells are produced by the marrow. NKcells activity is influenced by various cytokines and hormones produced by a body. In our work we allow for inhibiting effects exerted by hydrocortisone and stimulating influence by interleukin-2 [24, 28, 36].

Infected cells produce interferon and it is another mechanism of primary anti-virus body protection $[31,39,40]$. Interferon influences neighboring uninfected cells and invokes resistance to virus infection in them [20]. This resistance is temporary and then cells transfer into adiaphoria thus becoming resistant to interferon influence for a while [33]. There are basic mechanisms of specific acquired immune response: Bcells produce antibodies [16], which bind free viruses, and cytotoxic T-lymphocytes destroy cells infected with viruses [36]. Active reproduction of the abovementioned immune response cells starts after a body gives its first signals that a virus infection has occurred; these signals are given via stimulating effects by interleukin2. Activation of antibodies production by Bcells and T-killers entering the circulatory and lymphatic systems occurs only when a number of specific cells reaches a certain level. Hydrocortisone inhibits antiviral activity of the examined cells. The initial number of acquired immune response cells depends on the marrow functional state and previous case history of a body being infected with this virus.

Basing on the above-given interaction scheme we can describe a mathematical model of the regulation mechanism comprising elements of the immune and endocrine system with the help of the designed model which is a system consisting of 18 ordinary first-order differential equations with a retarded argument (1): 


$$
\begin{aligned}
& \int \frac{d C_{H E}}{d t}=k_{1}\left(C_{H E}+C_{R}\right) C_{D}+k_{2} C_{R}-k_{3} C_{H E} C_{I F N}-k_{4} C_{H E} C_{V} \\
& \frac{d C_{I}}{d t}=k_{4} C_{H E} C_{V}-k_{5} C_{N K} C_{I} C_{I L 2}\left(1-k_{8} \frac{C_{K}(t-T)}{\mathrm{k}_{47}+C_{K}(t-T)}\right)- \\
& -k_{6} C_{C T L} C_{I}\left(1-k_{9} \frac{C_{K}(t-T)}{\mathrm{k}_{47}+C_{K}(t-T)}\right) H\left(C_{C T L}-k_{46}\right)-k_{7} C_{I} \\
& \frac{d C_{R}}{d t}=k_{3} C_{H E} C_{I F N}-k_{2} C_{R} \\
& \frac{d C_{I F N}}{d t}=k_{10} C_{I}-k_{11} C_{H E} C_{I F N}-k_{12} C_{I F N} \\
& \frac{d C_{D}}{d t}=k_{7} C_{I}+k_{5} C_{N K} C_{I} C_{I L 2}\left(1-k_{8} \frac{C_{K}(t-T)}{\mathrm{k}_{47}+C_{K}\left(t-T_{2}\right)}\right)+ \\
& +k_{6} C_{C T L} C_{I}\left(1-k_{9} \frac{C_{K}(t-T)}{\mathrm{k}_{47}+C_{K}(t-T)}\right) H\left(C_{C T L}-k_{46}\right)-k_{13} C_{D} C_{M} \\
& \frac{d C_{V}}{d t}=k_{14} C_{I}-k_{15} C_{V} C_{A}-k_{16} C_{V} C_{H E}-k_{17} C_{V} \\
& \frac{d C_{M}}{d t}=k_{18} F_{b}-k_{19} C_{M} \\
& \left\{\frac{d C_{I L 1}}{d t}=k_{20} C_{M} C_{D}\left(1-k_{21} \frac{C_{K}(t-T)}{\mathrm{k}_{47}+C_{K}(t-T)}\right)-k_{22} C_{I L 1}\right. \\
& \frac{d C_{T H}}{d t}=k_{23} F_{b}-k_{24} C_{T H} \\
& \frac{d C_{I L 2}}{d t}=k_{25} C_{T H} C_{I L 1}-k_{26} C_{I L 2} \\
& \frac{d C_{N K}}{d t}=k_{27} F_{b}-k_{28} C_{N K} \\
& \frac{d C_{C T L}}{d t}=k_{29}+k_{30} C_{C T L} C_{I L 2}-k_{32} C_{C T L}-k_{31} C_{C T L} C_{I}\left(1-k_{9} \frac{C_{K}(t-T)}{\mathrm{k}_{47}+C_{K}(t-T)}\right) H\left(C_{C T L}-k_{46}\right) \\
& \frac{d C_{B}}{d t}=k_{46}+k_{33} C_{B} C_{I L 2}-k_{34} C_{B} \\
& \frac{d C_{A}}{d t}=k_{35} C_{B}\left(1-k_{36} \frac{C_{K}(t-T)}{\mathrm{k}_{47}+C_{K}(t-T)}\right) H\left(C_{B}-k_{45}\right)-k_{37} C_{V} C_{A}-k_{38} C_{A} \\
& \frac{d C_{C R H}}{d t}=\mathrm{k}_{48} F_{h}\left(1-k_{39} \frac{C_{K}(t-T)}{\mathrm{k}_{47}+C_{K}(t-T)}\right)\left(1+k_{40} C_{I L 1}\right)-k_{41} C_{C R H} \\
& \frac{d C_{A C T H}}{d t}=\mathrm{k}_{49} F_{p}\left(1-k_{42} \frac{C_{K}(t-T)}{\mathrm{k}_{47}+C_{K}(t-T)}\right) C_{C R H}-k_{43} C_{A C T H} \\
& \frac{d C_{K}}{d t}=\mathrm{k}_{50} F_{a} C_{A C T H}(t-T)-k_{44} C_{K}
\end{aligned}
$$


were $C_{A}-$ antibodies concentration, $[\mathrm{mIU} / \mathrm{ml}]$

$C_{A C T H}-$ is adrenocorticotropic hormone (ACTH) concentration, $[\mathrm{picogram} / \mathrm{ml}(\mathrm{pg} / \mathrm{ml})]$;

$C_{B}-$ is B-cells concentration, [cells $/ \mathrm{ml}$;

$C_{C T L}-$ is cytotoxic T-lymphocytes concentration, [cells $/ \mathrm{ml}$;

$C_{C R H}-$ is corticoliberin concentration, $[\mathrm{pg} / \mathrm{ml}]$

$C_{D}$ - is number of dead cells in a target organ, [cells];

$C_{H E}$ - is number of healthy cells in a target organ, [cells];

$C_{I}-$ is number of infected cells in a target organ, [cells];

$C_{I L 1}-$ is interleukin-1 concentration, $[\mathrm{pg} / \mathrm{ml}]$

$C_{I L 2}-$ is interleukin-2 concentration, $[\mathrm{pg} / \mathrm{ml}]$

$C_{I F N}-$ is interferon concentration, $[\mathrm{ME} / \mathrm{ml}]$;

$C_{K}-$ is hydrocortisone concentration, [nanogram $/ \mathrm{ml}$;

$C_{M}-$ is macrophages (monocytes) concentration, [cells $/ \mathrm{ml}$;

$C_{N K}-$ is NK-cells (natural killers) concentration, [cells $/ \mathrm{ml}$;

$C_{R}$ - is number of resistant cells in a target organ, [cells];

$C_{T H}-$ is T-helpers concentration, [cells $/ \mathrm{ml}]$;

$C_{V}-$ is antigens concentrations, [cop$\mathrm{ies} / \mathrm{ml}]$

$F_{a}-$ is adrenals functional capacity, synthesizing function, [dimensionless value];

$F_{b}-$ is marrow functional capacity, synthesizing function, [dimensionless value];

$F_{h}$ - is hypothalamus functional capacity, synthesizing function, [dimensionless value];
$F_{p}$ - is hypophysis functional capacity, synthesizing function, [dimensionless value].

The model parameters were indentified on the basis of experimental data obtained during research on a process of a body being infected with a flu virus; parameters values are given in Table.

We suggest to consider functional disorders in the immune system on the example of the marrow which produces immunocytes. Functional changes in the marrow occurring due to various reasons, chemical contamination included, influence rates at which various inborn and acquired immunity cells are produced. In future it leads both to quantitative (immunocytes and auxiliary immune system cells number dynamics) and qualitative (lower functional activity of immune-competent and auxiliary cells) changes in the immunity, including those evolving due to autoregulation mechanisms disorders. Functional disorders in the neuroendocrine system elements which we described earlier and which can be caused by chemical environmental factors $[3,5]$, in their turn, are able to result in the "outer" immune system failure and lower immune response efficiency.

To describe this factor, we apply a mathematical model which allows to predict functional disorders evolution under exposure to environmental factors. The model allows for body age-related peculiarities, and functional disorders accumulation due to natural processes occurring in a body and environmental factors impacts.

Disorders in each organ's functional abilities is characterized with a functional damage parameter . ; means an organ functions properly (perfectly). means an organ is unable to fulfill its functions. 
Parameters of the mathematical model describing interactions between the immune and endocrine systems under a virus infection

\begin{tabular}{|c|c|c|c|c|c|}
\hline Parameter & Value & Source & Parameter & Value & Source \\
\hline $\mathrm{k}_{1}$ & $2.35^{*} 10^{-11}[1 /$ cells*day $]$ & [34] & $\mathrm{k}_{27}$ & $1.1 * 10^{14}[$ cells $/ \mathrm{ml} *$ day $]$ & \\
\hline $\mathrm{k}_{2}$ & $0.98[1 /$ day $]$ & [36] & $\mathrm{k}_{28}$ & $0.11[1 /$ day $]$ & \\
\hline $\mathrm{k}_{3}$ & $1.1 * 10^{-17}[\mathrm{ml} / \mathrm{IU} * \mathrm{day}]$ & [21] & $\mathrm{k}_{29}$ & $4 * 10^{15}[$ cells $/ \mathrm{ml} *$ day $]$ & [36] \\
\hline $\mathrm{k}_{4}$ & $2 * 10^{-12}[\mathrm{ml} /$ copies*day $]$ & [36] & $\mathrm{k}_{30}$ & $4.15[\mathrm{ml} / \mathrm{pg} *$ day $]$ & [36] \\
\hline $\mathrm{k}_{5}$ & $2.5 * 10^{-17}\left[\mathrm{ml}^{2} /\right.$ cells*pg*day $]$ & & $\mathrm{k}_{31}$ & $1.6 * 10^{-111}[1 /$ cells $*$ day $]$ & [21] \\
\hline $\mathrm{k}_{6}$ & $6.6^{*} 10^{-18}[\mathrm{ml} / \mathrm{pg} *$ day $]$ & [21] & $\mathrm{k}_{32}$ & $0.4[1 / \mathrm{day}]$ & [36] \\
\hline $\mathrm{k}_{7}$ & $1.5[1 / \mathrm{day}]$ & [2] & $\mathrm{k}_{33}$ & $5.75[\mathrm{ml} / \mathrm{pg} *$ day $]$ & [36] \\
\hline $\mathrm{k}_{8}$ & 0.5 [dimensionless] & & $\mathrm{k}_{34}$ & $0.4[1 /$ day $]$ & [36] \\
\hline $\mathrm{k}_{9}$ & 0.5 [dimensionless] & & $\mathrm{k}_{35}$ & $7.56 * 10^{12}[\mathrm{mIU} / \mathrm{cellls}]$ & [36] \\
\hline $\mathrm{k}_{10}$ & $3.2 * 10^{6}[\mathrm{IU} / \mathrm{cells} * \mathrm{ml} *$ day $]$ & & $\mathrm{k}_{36}$ & 0.5 [dimensionless] & \\
\hline $\mathrm{k}_{11}$ & $1.01 * 10^{-10}[1 /$ cells $*$ day $]$ & [21] & $\mathrm{k}_{37}$ & $8.6^{*} 10^{-10}\left[\mathrm{ml} /\right.$ copies $^{*}$ day $]$ & [21] \\
\hline $\mathrm{k}_{12}$ & $8[1 /$ day $]$ & [21] & $\mathrm{k}_{38}$ & $0.043[1 /$ day $]$ & [36] \\
\hline $\mathrm{k}_{13}$ & $10^{-14}[\mathrm{ml} /$ cells*day $]$ & & $\mathrm{k}_{39}$ & 0.5 [dimensionless] & \\
\hline $\mathrm{k}_{14}$ & $510\left[\right.$ copies $/ \mathrm{ml}^{*}$ cells*day] & [2] & $\mathrm{k}_{40}$ & $0.002[\mathrm{ml} / \mathrm{pg}]$ & \\
\hline $\mathrm{k}_{15}$ & $8.6^{*} 10^{-10}\left[\mathrm{ml} / \mathrm{mIU}^{*}\right.$ day $]$ & [43] & $\mathrm{k}_{41}$ & $3.767[1 / \mathrm{day}]$ & [26] \\
\hline $\mathrm{k}_{16}$ & $6.1 * 10^{-12}[1 /$ cells*day $]$ & [21] & $\mathrm{k}_{42}$ & 0.5 [dimensionless] & \\
\hline $\mathrm{k}_{17}$ & $1.7[1 /$ day $]$ & [21] & $\mathrm{k}_{43}$ & $0.7572[1 /$ day $]$ & [38] \\
\hline $\mathrm{k}_{18}$ & $3 * 10^{9}[\mathrm{cells} / \mathrm{ml} *$ day $]$ & [36] & $\mathrm{k}_{44}$ & $0.1972[1 /$ day $]$ & [38] \\
\hline $\mathrm{k}_{19}$ & $0.03[1 /$ day $]$ & [36] & $\mathrm{k}_{45}$ & $1.8139 * 10^{20}[$ cells $/ \mathrm{ml}]$ & \\
\hline $\mathrm{k}_{20}$ & $2.94 * 10^{-19}\left[\mathrm{pg} / \mathrm{cells}^{2} *\right.$ day $]$ & [20] & $\mathrm{k}_{46}$ & $0.4 * 10^{16}[\mathrm{cells} / \mathrm{ml}]$ & [36] \\
\hline $\mathrm{k}_{21}$ & 0.5 [dimensionless] & & $\mathrm{k}_{47}$ & $3.055[\mathrm{ng} / \mathrm{ml}]$ & [42] \\
\hline $\mathrm{k}_{22}$ & $0.1245[1 / \mathrm{day}]$ & [27] & $\mathrm{k}_{48}$ & $7.659[\mathrm{pg} / \mathrm{ml}]$ & [26] \\
\hline $\mathrm{k}_{23}$ & $5.8 * 10^{3}[$ cells $/ \mathrm{ml} *$ day $]$ & & $\mathrm{k}_{49}$ & $21[\mathrm{pg} / \mathrm{ml}]$ & [38] \\
\hline $\mathrm{k}_{24}$ & $0.0058[1 /$ day $]$ & & $\mathrm{k}_{50}$ & $3.055[\mathrm{ng} / \mathrm{ml}]$ & [42] \\
\hline $\mathrm{k}_{25}$ & $3.28 * 10^{-7}[\mathrm{ml} / \mathrm{cellls} *$ day $]$ & & $\mathrm{T}$ & 0.0132 [day] & [42] \\
\hline $\mathrm{k}_{26}$ & $0.248[1 /$ day $]$ & & & $1.1 * 10^{14}[$ cells $/ \mathrm{ml} *$ day $]$ & \\
\hline
\end{tabular}

Outer (for an organ being considered) impacts and internal degradation (ageing) are basic reasons for damages in it. Outer impacts are hazardous substances penetrating into a body and influencing damages to an organ.

Assuming that damages speeds depend on various factors, we suggest the following structure of equations describing evolution of functional damages to human organs (2):

$$
\frac{d F}{d t}=\alpha F+\sum_{i=1}^{n} \beta_{i}\left\langle\frac{p_{i}}{p_{i}^{N}}-1\right\rangle,
$$

where $\alpha-$ is a coefficient which characterizes a speed at which an organ grows older [1/year];

$\beta_{i}$ - is a coefficient which characterizes a value of impacts exerted by $i$-th hazardous factors on functional damages to an organ [1/ year]; $p_{i}$ - is i-th hazardous substance introduction into a human body;

$p_{i}^{N}$ - is standard (maximum permissible) value of $i$-th substance introduction for an organ being considered.

So called McCauley brackets are given as $\langle x\rangle$ будут обозначаться так называемые скобки Мак-Кейли (McCauley): $\langle x\rangle=0$ при $x<0$ и $\langle x\rangle=x$ при $x \geq 0$.

The first summand in the equation (2) makes an additional contribution into functional damages due to an increase in the intensity an undamaged part of an organ functions with in case any structural damages disorders occur; this increased intensity results from the necessity for a healthy part of an organ to enter an enhanced mode required for proper organ functioning. This enhanced functioning mode decreases cells life and causes faster organ destruction. 
The second summand characterizes damages caused by environmental factors which can occur due to excessive hazardous substances introduction. The suggested structure describes the overall picture of damages evolution and allows for selfdestruction (natural ageing) and damages accumulation caused by hazardous substances introduction which is beyond the set standards.

As all the equations in the model are complicated and non-linear, it becomes more difficult to obtain analytical solution with its application. To solve the differential equation system, we apply implicit numerical technique by Runge-Kutta of the third order.

Results and discussion. To test our model, we performed a numerical experiment and implemented three possible scenarios of the system behavior. The difference between them was related to the degree of disorders in the marrow synthesizing function, and this degree was determined by the intensity of impacts exerted by negative chemical factors. Each scenario involved breaking the system balance by setting up the initial viruses level. The results are given in Figures 2.

Our first scenario modeled virus invasion and a body successful fighting against it $\left(F_{b}=1\right)$. Initially macrophages produced interleukin-1 which stimulated interleukin2 production. The latter in its turn activated NK-cells which were already present in a body; they rapidly inhibited infected cells thus preventing viruses from being released. After all viruses were successfully destroyed, interleukin-1 concentration went down to zero. Tentatively speaking, we can assume that it will correspond either to absence of any clinical signs of a disease or to a very mild form of it which will result in complete and fast recovery.

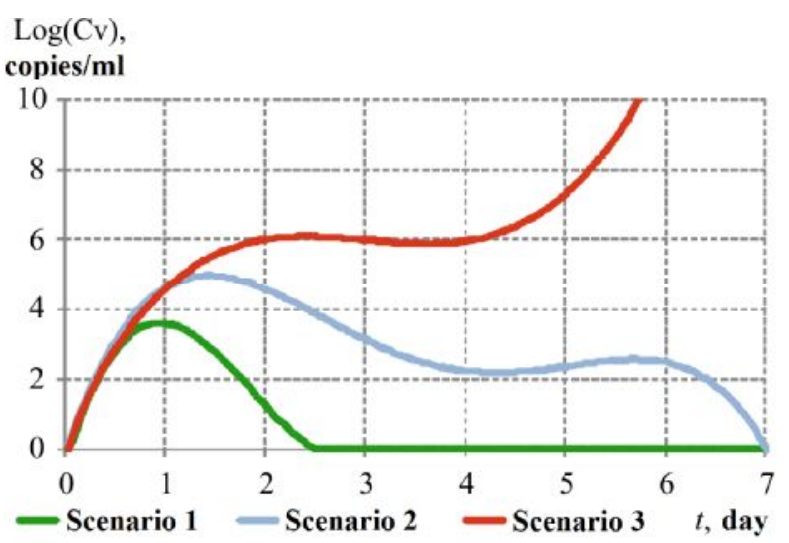

$a$

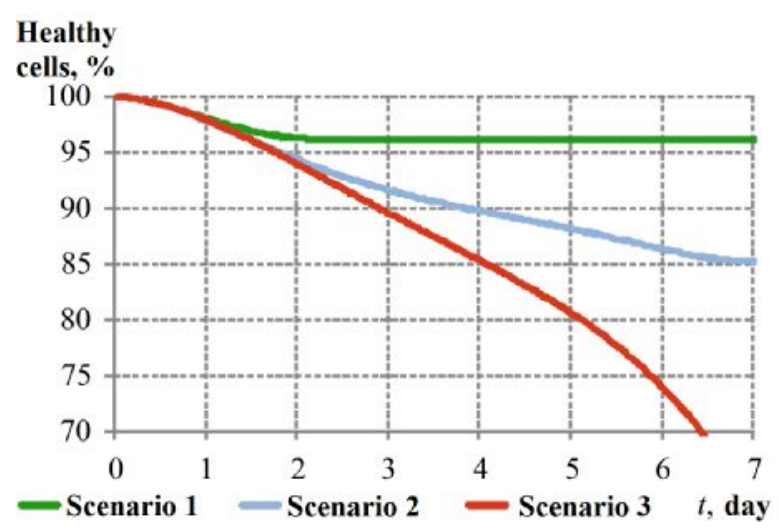

$b$

Figure. 2. $a-$ Graph showing changes in number of virus copies in a body over time and depending on damages to the marrow synthesizing function Graph showing changes in number of virus copies in a body over time and depending on damages to the marrow synthesizing function; $b$ - Graph showing changes in $\%$ of healthy cells quantity against their initial level

The second scenario describes activation of not only inborn immunity but also acquired one $\left(F_{b}=0,85\right)$. If we take clinical practices, a disease with average gravity can be an example of such a scenario. At initial stages fighting against a virus is based on inborn immunity. But a body can't overcome it and viruses continue to reproduce themselves. Acquired immunity activations occurs on the fifth day and a number of viruses goes down rapidly. We can observe this scenario when the marrow 
synthesizing function is a bit weakened, when virus load is substantial, or when there is no immune memory about this concrete type of viruses.

The third scenario concentrates on virus invasion in case when the marrow synthesizing function is significantly reduced $\left(F_{b}=0,7\right)$ as a result of adverse impacts exerted by the environment. These impacts cause initially low levels of macrophages, NK-cells, B-cells, and cytotoxic Tlymphocytes in a body. As a result a number of viruses in a body grows continuously. It can correspond to a very serious disease or even lethal outcome of it.

When an infection occurs, a number of healthy cells in a target organ gradually goes down due to negative impacts exerted by viruses. There are the following gradations for damages to a target organ tissue corresponding to a disease clinical form: damage to less than $8-10 \%$ of a tissue corresponds to a mild disease; $10-20 \%$, an av- erage disease; $20-25 \%$, a grave disease; when more than $25-30 \%$ of a target organ tissue is damaged, lethal outcome is rather probable [6].

Conclusions. So, the suggested predictive mathematical model of regulatory systems functioning under virus invasion and under exposure to chemical factors represents the occurring processes quite qualitatively and sufficiently. This model is a simplified variant of a complicated multicomponent process of interaction between regulatory systems under chemical contamination when virus invasion occurs. However, it allows to show mechanics of multicomponent interaction between regulatory systems when inflammatory reactions of viral genesis evolve. Basing on it, in future we plan to expand the model component structure possibly performing population analysis of dependence between infectious morbidity and chemical contamination.

\section{References}

1. Voronin E.E., Latysheva I.B. VICh-infektsiya v Rossiiskoi Federatsii [HIV in the Russian Federation]. Ural'skii meditsinskii zhurnal, 2016, no. 9 (142), pp. 6-8 (in Russian).

2. Zhdanov V.M., Bukrinskaya A.G. Reproduktsiya miksovirusov (virusov grippa i skhodnykh s nimi) [Mixoviruses reproduction (influenza viruses and those similar to them)]. Moscow, Meditsina, Publ., 1969, 280 p. (in Russian).

3. Zaitseva N.V., Lanin D.V., Chereshnev V.A. Immunnaya i neiroendokrinnaya regulyatsiya $\mathrm{v}$ usloviyakh vozdeistviya khimicheskikh faktorov razlichnogo geneza [Immune and neuroendocrine regulation under exposure to chemical factors of various genesis]. Perm', Izdatel'stvo Permskogo natsional'nogo issledovatel'skogo politekhnicheskogo universiteta, Publ., 2016, 236 p. (in Russian).

4. Lanin D.V., Zaitseva N.V., Dolgikh O.V. Neiroendokrinnye mekhanizmy regulyatsii funktsii immunnoi sistemy [Neuroendocrine Mechanisms for Regulation of Immune System]. Uspekhi sovremennoi biologii, 2011, no. 2, pp. 122-134 (in Russian).

5. Lanin D.V., Lebedeva T.M. Vozdeistvie khimicheskikh faktorov sredy obitaniya na funktsii i vzaimosvyazi regulyatornykh sistem u detei [The influence of chemical environmental factors on functions and interrelationships of regulatory systems in children]. Gigiena i sanitariya, 2016, vol. 95, no. 1, pp. 94-96 (in Russian). 
6. Marchuk G.I., Berbentsova E.P. Ostrye pnevmonii. Immunologiya, otsenka tyazhesti, klinika, lechenie [Acute pneumonias. Immunology, gravity assessment, clinical course, and treatment]. Moscow, Nauka,Publ., 1989, 304 p. (in Russian).

7. Zaitseva N.V., Shur P.Z., May I.V., Kiryanov D.A. Metodicheskie podkhody k otsenke integral'nogo riska zdorov'yu naseleniya na osnove evolyutsionnykh matematicheskikh modelei [Approaches to the assessment of integrated health risk population based on evolution of mathematical models]. Zdorov'e naseleniya i sreda obitaniya, 2011, no. 10, pp. 6-9 (in Russian).

8. Stepanenko L.A., Savchenkov M.F., Il'ina S.V., Anganova E.V., Savilov E.D. Otsenka sostoyaniya immunnoi sistemy detskogo naseleniya kak markera tekhnogennogo zagryazneniya okruzhayushchei sredy [An assessment of the immune status of the children population as a marker of technogenic pollution of the environment]. Gigiena i sanitariya, 2016, vol. 95, no.12, pp. 1129-1133 (in Russian).

9. Poletaev A.B., Morozov S.G., Kovalev I.E. Regulyatornaya metasistema (immunoneiroendokrinnaya regulyatsiya gomeostaza) [Regulatory meta-system (immuneneuroendocrine homeostasis regulation)]. Moscow, Meditsina, Publ., 2002, 166 p. (in Russian).

10. Savilov E.D., Il'ina S.V. Osobennosti infektsionnoi patologii detskogo naseleniya v usloviyakh tekhnogennogo zagryazneniya okruzhayushchei sredy [Features of Infectious Pathology in the Child Population in the Conditions of Technogenic Pollution of the Environment]. Epidemiologiya i vaktsinoprofilaktika, 2012, no. 1 (62), pp. 58-63 (in Russian).

11. Savilov E.D., Mal'tsev M.V. Epidemiologicheskaya kharakteristika virusnogo gepatita $\mathrm{S} \mathrm{v}$ usloviyakh krupnogo promyshlennogo goroda [Epidemiological characteristic of viral hepatitis $\mathrm{c}$ in large industrial city settings]. Zhurnal mikrobiologii, epidemiologii $i$ immunobiologii, 2007, no. 1, pp. 70-71 (in Russian).

12. Stepanenko L.A., Il'ina S.V., Savilov E.D. Osobennosti sostoyaniya spetsificheskogo immuniteta $\mathrm{k}$ upravlyaemym infektsiyam u detei (na primere kori i poliomielita) $\mathrm{v}$ usloviyakh vozdeistviya tekhnogennoi nagruzki [Peculiarities of specific immunity to manageable infections in children (on the examples of measles and polyomielitis) under impacts exerted by technogenic loads]. Byulleten' Vostochno-Sibirskogo nauchnogo tsentra Sibirskogo otdeleniya Rossiiskoi akademii meditsinskikh nauk, 2007, no. S3, pp. 66-68 (in Russian).

13. Savilov E.D., Anganova E.V., Il'ina S.V., Stepanenko L.A. Tekhnogennoe zagryaznenie okruzhayushchei sredy i zdorov'e naseleniya: analiz situatsii i prognoz [Technogenic environmental pollution and the public health: analysis and prognosis]. Gigiena $i$ sanitariya, 2016, vol. 95, no. 6, pp. 507-512 (in Russian).

14. Zaitseva N.V., Kiryanov D.A., Lanin D.V., Chigvintsev V.M. A mathematical model of the immune and neuroendocrine systems mutual regulation under the technogenic chemical factors impact. Computational and Mathematical Methods in Medicine, 2014. Available at: https://www.hindawi.com/journals/cmmm/2014/492489/abs/ (18.04.2017)

15. Andrew M.E., Churilla A.M., Malek T.R., Braciale V.L., Braciale T.J. Activation of virus specific CTL clones: antigen-dependent regulation of interleukin 2 receptor expression. $J \mathrm{Im}$ munol, 1985, no. 134 (2), pp. 920-925.

16. Tamura S.I., Iwasaki T., Thompson A.H., Asanuma H., Chen Z., Suzuki Y., Aizawa C., Kurata T. Antibody-forming cells in the nasal-associated lymphoid tissue during primary influenza virus infection. Journal of General Virology, 1998, vol.79, no. 2, pp. 291-299.

17. Ashley N.T., Demas G.E. Neuroendocrine-immune circuits, phenotypes, and interactions. Hormones and Behavior, 2017, vol. 87, pp. 25-34.

18. Bairagi N., Chatterjee S., Chattopadhyay J. Variability in the secretion of corticotropin-releasing hormone, adrenocorticotropic hormone and cortisol and understandability of the hypothalamic-pituitary-adrenal axis dynamics - a mathematical study based on clinical evidence. Mathematical Medicine and Biology, 2008, vol. 25, no. 1, pp. 37-63. 
19. Bellavance M., Rivest S. The neuroendocrine control of the innate immune system in health and brain diseases. Immunological Reviews, 2012, vol. 248, no. 1, pp. 36-55.

20. Bocharov G.A., Romanyukha A.A. Mathematical model of antiviral immune response III. Influenza A virus infection. Journal of Theoretical Biology, 1994, vol. 167, no. 4, pp. 323360 .

21. Chapman C.R., Tuckett R.P., Song C.W. Pain and Stress in a Systems Perspective: Reciprocal Neural, Endocrine, and Immune Interactions. Journal of Pain, 2008, vol. 9, no. 2, pp. $122-145$.

22. Zabel P., Horst H.J., Kreiker C., Schlaak M. Circadian rhythm of interleukin-1 production of monocytes and the influence of endogenous and exogenous glucocorticoids in man. Klinische Wochenschrift, 1990, vol. 68, no. 24, pp. 1217-1221.

23. Bergeron Y., Ouellet N., Deslauriers A., Simard M., Olivier M., Bergeron M. Cytokine kinetics and other host factors in response to pneumococcal pulmonary infection in mice. Infect. Immun, 1998, vol. 66, no. 3, pp. 912-922.

24. Demas G.E., Adamo S.A., French S.S. Neuroendocrine-immune crosstalk in vertebrates and invertebrates: Implications for host defence. Functional Ecology, 2011, vol. 25, no. 1, pp. 29-39.

25. Pace T.W., Negi L.T., Adame D.D., Cole S.P., Sivilli T.I., Brown T.D., Issa M.J., Raison C.L. Effect of compassion meditation on neuroendocrine, innate immune and behavioral responses to psychosocial stress. Psychoneuroendocrinology, 2009, no. 34, pp. 87-98.

26. Felig P., Frohman L. Endocrinology and metabolism, 4er ed. New York, McGraw-Hill, Publ., 2001, 1562 p.

27. Gloff C., Wills R. Pharmacokinetics and Metabolism of Therapeutic Cytokines. In B. Ferraiolo, M. Mohler, C. Gloff, eds. New York, Plenum Press, Publ., 1992, pp. 127-150.

28. Haus E., Smolensky M.H. Biologic rhythms in the immune system. Chronobiology international, 1999, vol. 16, no. 5, pp. 581-622.

29. Heffner K.L. Neuroendocrine Effects of Stress on Immunity in the Elderly: Implications for Inflammatory Disease. Immunology and Allergy Clinics of North America, 2011, vol. 31, no. 1, pp. 95-108.

30. Heijnen C.J. Receptor regulation in neuroendocrine-immune communication: current knowledge and future perspectives. Brain, behavior, and immunity, 2007, vol. 21, no. 1, pp. 1-8.

31. Julkunen I., Melen K., Nyqvist M., Pirhonen J., Sareneva T., Matikainen S. Inflammatory responses in influenza A virus infection. Vaccine, 2000, vol. 19, no. 1, pp. 32-37.

32. Muraguchi A., Kehrl J.H., Longo D.L., Volkman D.J., Smith K.A., Fauci A.S. Interleukin 2 receptors on human B cells. Implications for the role of interleukin 2 in human B cell function. The Journal of experimental medicine, 1985, vol. 161, no. 1, pp. 181-97.

33. Joklik W.K. Interferons. In: B.N. Fields, ed. New York, Raven Press, Publ., 1985, pp. 281-307.

34. Keenan K.P., Combs J.W., McDowell E.M. Regeneration of hamster tracheal epithelium after mechanical injury. Virchows Archiv B Cell Pathology Including Molecular Pathology, 1983, vol. 42, no. 1, pp. 231-252.

35. Kerdiles Y., Ugolini S., Vivier E. T cell regulation of natural killer cells. The Journal of Experimental Medicine, 2013, vol. 210, no. 6, pp. 1065-1068.

36. Marchuk G.I., Petrov R.V., Romanyukha A.A., Bocharov G.A. Mathematical model of antiviral immune response. I. Data analysis, generalized picture construction and parameters evaluation for hepatitis B. Journal of Theoretical Biology, 1991, vol. 151, no. 1, pp. 1-40.

37. Miyake S. Mind over cytokines: Crosstalk and regulation between the neuroendocrine and immune systems. Clinical and Experimental Neuroimmunology, 2012, vol. 3, no. 1, pp. 115. 
38. Carroll B.J., Cassidy F., Naftolowitz D., Tatham N.E., Wilson W.H., Iranmanesh A., Liu P.Y., Veldhuis J.D. Pathophysiology of hypercortisolism in depression. Acta Psychiatrica Scandinavica, 2007, vol. 115, pp. 90-103.

39. Ronni T., Sareneva T., Pirhonen J., Julkunen I. Activation of IFN-alpha, IFN-gamma, $\mathrm{MxA}$, and IFN regulatory factor 1 genes in influenza A virus-infected human peripheral blood mononuclear cells. Journal of immunology, 1995, vol. 154, no. 6, pp. 2764-2774.

40. Sareneva T., Matikainen S., Kurimoto M., Julkunen I. Influenza A virus-induced IFNalpha/beta and IL-18 synergistically enhance IFN-gamma gene expression in human T cells. Journal of immunology, 1998, vol. 160, no. 12, pp. 6032-6038.

41. Suarez E.C., Sundy J.S., Erkanli A. Depressogenic vulnerability and gender-specific patterns of neuro-immune dysregulation: What the ratio of cortisol to C-reactive protein can tell us about loss of normal regulatory control. Brain, Behavior, and Immunity, 2015, no. 44, pp. $137-147$.

42. Vinther F., Andersen M., Ottesen J.T. The minimal model of the hypothalamicpituitary-adrenal axis. Journal of Mathematical Biology, 2011, vol. 63, no. 4, pp. 663-690.

43. Wohlfartt C. Neutralization of Adenoviruses: Kinetics, Stoichiometry, and Mechanisms. J Immunol, 1988, vol. 62, no. 7, pp. 2321-2328.

44. World Health Organization World Health Organization. World health statistics 2016: monitoring health for the SDGs, sustainable development goals. World Health Organization, 2016, $121 \mathrm{p}$.

Trusov P.V., Zaitseva N.V., Chigvintsev V.M., Lanin D.V. Mathematical model for describing anti-virus immune response regulation allowing for functional disorders in a body. Health Risk Analysis, 2017, no. 4, pp. 117-128. DOI: 10.21668/health.risk/2017.4.13.eng

Received: 18.08 .2017

Accepted: 20.12.2017

Published: 30.12.2017 


\title{
SCIENTIFIC REVIEWS
}

UDC 614/5: 644.36

DOI: $10.21668 /$ health.risk/2017.4.14.eng

\section{RISKS OF AGE RELATED MACULAR DEGENERATION AND LED LIGHTING}

\author{
V.A. Kaptsov" ${ }^{1}$, V.N. Deinego ${ }^{2}$ \\ ${ }^{1}$ All-Russian Research Institute of Railway Hygiene, 1 Pakgauznoe Shosse Str., Bldg. 1, Moscow, 125438, \\ Russian Federation \\ ${ }^{2}$ Scientific-Production Company «ELTAN LTD», 2 Zavodskoy avenue, Fryazino, 141190, Russian Federation
}

Spectral structure of environmental light can have significant influence on risks of various eye diseases which can evolve quite early. The paper dwells on how age-related macular degeneration evolves and on a part which eye age pigment plays in the process. We discuss predictive models for age pigment accumulation and methodology of their creation. We created a predictive mathematical model for accumulated A2E age pigment quantity allowing for LED lighting peculiarities and its age-related perception. The model encompasses active oxygen forms generation evolving due to decrease in antioxidant cellular protection efficiency in a lighting environment with a higher blue light dose. It is shown that superoxide dismutase, catalase and glutathione peroxidase 1 (GRX 1) efficiency within 445 (plus minus 10 nanometers) range drops substantially in blue light; it increases risks of lower cellular resistance to effects exerted by non-compensated active oxygen forms. These processes which are rather long-term can lead to early age-related macular degeneration. Mathematical calculations prove that in the nearest future a share of patients aged 30-40 who suffer from age-related macular degeneration will grow drastically; it will eventually lead to an increased number of disabled people aged 50-60 whose disability is caused by eyesight disorders. It is shown that if we fail to discover any mechanisms aimed at lowering risks of early age-related macular degeneration evolvement in the nearest future, total costs required for solving eyesight disorders issue will grow substantially. Thus, in 2012 about 140 billion dollars were spent on the eyesight disorders issue all over the world; the sum is likely to reach 377 billion dollars in 2050.

Key words: age-related macular degeneration, age pigment, antioxidant cellular protection, eye pathology prevention, lighting environment, LED lighting, blue light.

Age-related macular degeneration (AMD) is a degenerative progressive disease of the retina macular area which plays the leading role in central vision loss among elderly people in developed countries who spend $80-90 \%$ of their time under artificial lighting. AMD holds the first place among diseases causing poor vision and, as a rule, leads to two-side damage (both eyes are damaged in $60 \%$ cases). As per data given by the WTO, this pathology prevalence amounts to 300 people per 100 thousand, 25-30 million people all over the world suffer from
AMD. $25-40 \%$ of people older than 40 have this disease. This pathology is detected in $58 \%$ people who are older than 60. AMD evolvement becomes a more vital issue due to growth in elderly people share among overall population as well as due to the disease itself getting "younger", this process being induced by new computer and television technologies entering our lives and lives of your children [2]. Another problem here is overall lighting created mostly by artificial light sources. In Russia AMD is detected in more than 100 thousand people an-

(C) Kaptsov V.A., Deinego V.N., 2017

Valeriy A. Kaptsov - Corresponding Member of Russian Academy of Sciences, Doctor of Medical Sciences, professor, Head of the Occupational Health Department (e-mail: kapcovva39@mail.ru; tel.: + 7 (499) 15-33-628).

Vitaly N. Deinego - Lighting Technology Project Supervisor (e-mail: aet@aetechnologies.ru; tel.: + 7 (495) 280-76-07). 
nually; $20 \%$ out of them suffer from the disease evolving into "wet" ("neovascular") form.

Economic consequences which neovascular AMD evolvement has are significant for patients, their families, and the public healthcare system (lower life quality, loss of independence, and disability). Assessment of economic losses caused by population disability is stated in the Orders by the RF Economic Development Ministry, the RF Social Development Ministry, the RF Ministry of Finance, as well as in the Order by the Federal State Statistic Service No. 113 dated April 10, 2012 "On Approval of methodology for calculating economic losses caused by population mortality, morbidity, and disability" ${ }^{1}$.

AMD pathogenesis is known to be based on oxidation-reduction balance disorders in the eye retina. The main role in the process belongs to free radicals which appear in the retina structures under constant impacts exerted by active oxygen forms and light. Active oxygen forms appear due to influence exerted by external factors and the visual cycle as A2E (pyridinium bisretinoid) generates active oxygen forms under blue light influence when a certain pigment epithelium concentration is accumulated in the tissue culture [20]. ]. In the end the process causes cells death and age-related degradation evolvement in the eye retina, Stargardt disease, various retinopathies, and other dangerous eyesight diseases [9].

We can find lipofuscin in epithelium retinal pigment in the form of spherical particles of micron size; it has its own yellow fluorescence when being excited by blue light; this excitation leads to active intermediate oxygen forms occurrence.

Figure 1 shows the results of lipofuscin fluorescence distribution in the retina of people from various age groups.

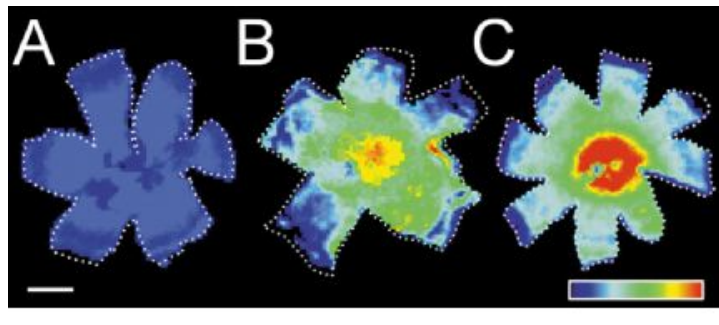

$a$

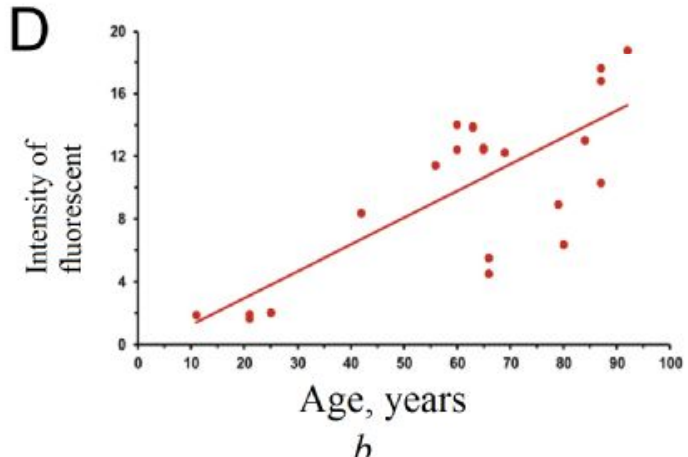

Figure. 1. Spatial distribution of lipofuscin

fluorescence in a human eye:

a) fluorescent images of the overall retina pigment epithelium in patients from various age groups: A - 21-year old, B-41-year old and $\mathrm{C}-65$-year old; images were taken via bio-luminescence system of image creation with radiation filter ranging from 575 to 650 nanometers (DC is red filter); b) measured overall intensity of lipofuscin fluorescence (DC red filter) grows with age ( $\mathrm{x}$ axis is age (years); $y$-axis is fluorescence intensi-

$$
\text { ty [19] }
$$

A group of researchers estimated some risks calculated via multiple logistic regression analysis and considered genetic and ecological risk factors (smoking, primary hypertension, body mass index, and diabetes) for various age groups [14]. The scientists analyzed various age groups $(<70$, 70-79 and 80-89 years, and neogenetics as well) for risk variants with $\mathrm{CFH}$ genes (hu-

\footnotetext{
${ }^{1}$ On Approval of methodology for calculating economic losses caused by population mortality, morbidity, and disability: The Order by the RF Economic Development Ministry No. 192, the Order by the RF Social Development Ministry No. 323n, the RF Ministry of Finance No. 45n, The Federal State Statistic Service No. 113 dated April 10, 2012 (registered by the RF Ministry of Justice on April 28, 2012 No. 23983). Available at: http://www.consultant.ru/document/cons doc LAW 129302/ (06.07.2017).
} 
man complement factor with genetic susceptibility to AMD and ARMS2 with age susceptibility). AMD probability is considered to increase due to three basic factors: $\mathrm{CFH}$ gene polymorphism (genetic marker is T1204C), $43 \%$; ARMS2 gene polymorphism (genetic marker is G205T), $36 \%$; and smoking, $20 \%$. Homozygotes as per changed (minor) alleles of CFH and ARMS2 genes run 50 times greater risk of AMD than basic alleles carriers [14].

The experts calculated AMD risks basing on stepwise logistic regression for genetic and ecological risk factors applying three interrelated logistic regression equations:

$$
\begin{aligned}
& \operatorname{logit}\left(p^{1}\right)=\log \left(p^{1} /\left[1-p^{1}\right]\right)= \\
& =b 0+b 1 \cdot \mathrm{ARMS} 2+b 2 \cdot \mathrm{CFH}
\end{aligned}
$$

$\operatorname{logit}\left(p^{2}\right)=\log \left(p^{2} /\left[1-p^{1}\right]\right)=b 0+$ $b 1 \cdot$ smoking +

$+b 2 \cdot$ bepertension $+b 3 \cdot \mathrm{BMI}+b 4 \cdot$ diabetes + $b 5 \cdot \operatorname{sex}$,

$$
\operatorname{logit}\left(p^{3}\right)=\log \left(p^{3} /\left[1-p^{2}\right]\right)=b 0+
$$
$b 1 \cdot \mathrm{ARMS} 2+$

$+b 2 \cdot \mathrm{CFH}+b 1 \cdot$ smoking $+b 2 \cdot$ bepertension

$$
+b 3 \cdot \mathrm{BMI}+b 4 \cdot \operatorname{diabetes}+b 5 \cdot \operatorname{sex}
$$

where $p^{1}-$ is AMD risk allowing for genetic influence;

$p^{2}-$ is AMD risk allowing for environmental factors;

$p^{3}$ - is AMD risk allowing for both genetic and ecological impacts.

AMD probability for each risk parameter was calculated with the following equation: $\mathrm{P}$ $=\exp (\operatorname{logit}[\mathrm{P}]) /(1+\exp [\operatorname{logit}\{\mathrm{P}\}])$ allowing for the extent to which external factors could influence it. The authors gave a profound description of their risk assessment procedure; each factor significance was determined o the basis of the following patients data: 2,737 people (1204 were the control group; 1433, the focus one), including 166 neogenetics (52 were the control group; 114, the focus one). Single nucleotide polymorphisms (SNP) were detected in ARMS2 and CFH genes. The authors consider genetic and age risk factors to exert much less significant influence on AMD evolvement in neogenetics while environmental factors exert the same effect in people from senior age groups [20].

F.C. Delori et al. suggested mathematical models for assessing lipofuscin accumulation with age, rate of its accumulation, and spatial distribution in the retina allowing for melanin [12]. The researchers revealed that melanin concentration in pigment epithelium cells changes with age. Generalized results of their assessment are given in Figure 2.

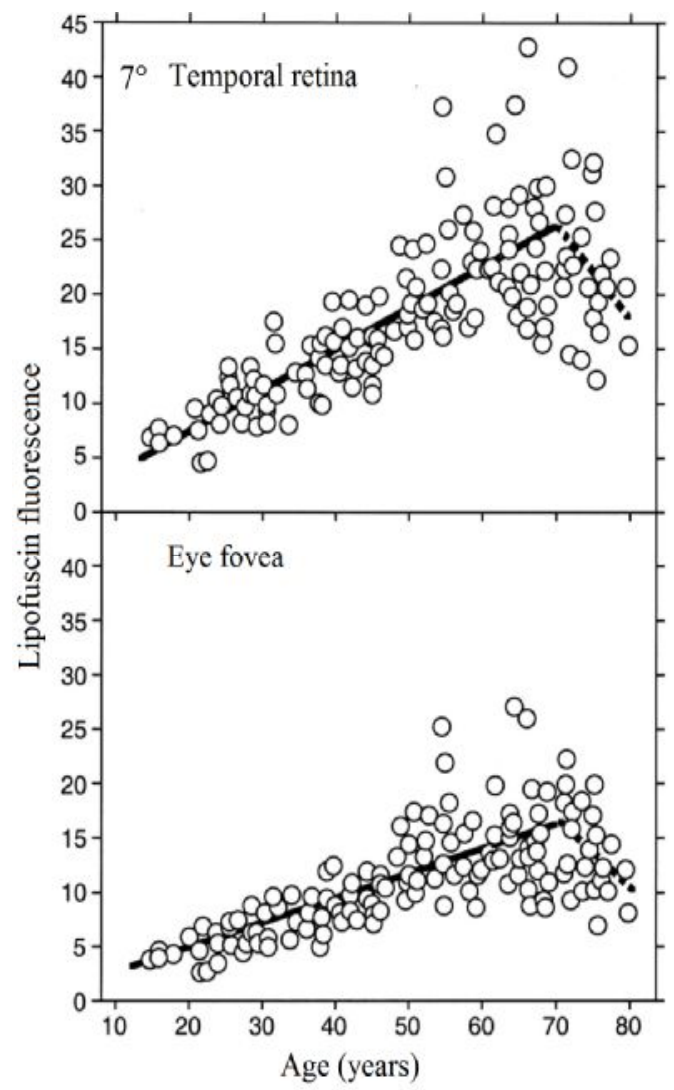

Figure 2. Lipofuscin fluorescence depending on age.Solid lines show linear regression equations at the age from 20 to 70 years $(\mathrm{P}<0.0001)$; broken lines show linear regression equations at the age from 70 to 80 years

$$
(\mathrm{p}<0.12)
$$

The following functional dependences for each age are suggested on the basis of regression analysis given in the paper [12]: 
-F15 is fluorescence in young patients (starting from 15), with all the melanin located apically to lipofuscin;

-F65 is fluorescence in old people (older than 65), with their melanin evenly mixing with lipofuscin over the whole cell.

These fluorescences are calculated as per the following formulas:

$$
F_{15}=\zeta d 10^{-\left[K_{\Lambda}+K_{\lambda}\right] D_{500}}
$$

or

$$
F_{65}=\frac{\zeta d\left\{1-10^{-\left[K_{\Lambda}+K_{\lambda}\right] D_{500}}\right\}}{\ln (10)\left[K_{\Lambda}+K_{\lambda}\right] D_{500}} .
$$

Lipofuscin fluorescence grew linearly up to 70 years, but then it decreased. Accumulation rate was significantly slower in the fossa than on the temporal area; accumulations rates in vivo were higher than it was previously observed in microscope examinations. Fluorescence was by $40 \%$ lower in the fossa than at the $7^{\circ}$ eccentricity and was asymmetrically distributed around the fossa. Fluorescence was maximum at $" 11^{\circ}$ at the temple", $7^{\circ}$ at the nose, "13 ${ }^{\circ}$ and higher", and "9 ${ }^{\circ}$ lower". Fluorescence at the same eccentricity was always lower as per the bottom meridian than as per any other one. Light absorption by melanin in pigment epithelium can explain differences between lipofuscin rates assessments in vivo and ex vivo. Decreasing fluorescence in older ages can be related to removal of atrophic cells in retinal pigment epithelium (RPE). Overall, spatial lipofuscin distribution coincides with rods spatial distribution and reflects, but does not predict, an age loss picture [12]. This statement has a very important consequence, namely, retina flare spot square which depends on a pupil diameter in this light environment should be smaller than a square of the macula with cones which are reliably protected with the yellow spot [5].

J.P. Greenberg in his work measured a qAF auto-fluorescence quantitative param- eter of the retina ground in a healthy patient with the use of the standardized approach [25]. His goal was to detect standard data and determine factors which can influence lipofuscin accumulation in pigment epithelium cells and/or simulate AF observed signal in the retina ground images. AF images were obtained in 277 healthy people (age ranging from 5 to 60 years) using Spectralis confocal scanning ophthalmoscope (cSLO, 488 nanometers excitation, $30^{\circ}$ ) equipped with an internal fluorescent etalon. Average level of grey for each image was calculated as a mean of eight pre-set areas and was gauged as per etalon zero light, optical carriers magnification and density as per standard data on lens transmission spectra. He also estimated correlation between $\mathrm{qAF}$ and age, sex, race/ethnic group, eyes color, refraction/axial length, and smoking status; he also examined measurement repeatability and qAF spatial distribution. The research involved application of linear regression equations for mixed effects which allowed for inter-subject correlations between eyes (Stata, College Station, TX). After tasting various models, he obtained the best linear diagram with the following exponential model:

$$
\begin{gathered}
\log (\mathrm{qAFs})=\mathrm{B} 0+\mathrm{B} 1 \text { factor }_{1}+\ldots+ \\
+ \text { Bn factor }_{\mathrm{n}}+\text { Bage log }(\text { age }),
\end{gathered}
$$

where factor $_{1}$ и factor $_{\mathrm{n}}$ were a combination of binary and contiguous factors. Binary factors in the model included sex, race, and ethnic group.

Calculations revealed that qAF levels grew substantially with age; grew with the eccentricity rising from 108 to 158; were higher in women; were substantially higher in whites than in Latin Americans; were lowers in Asian people and Negros than in Latin Americans. There were no relations between an eye axis length and smoking. The authors came to the conclusion that $\mathrm{qAF}$ standard levels were a reference tool neces- 
sary for interpreting qAF measurements in case of eyes diseases.

The above-mentioned models are true for predicting $\mathrm{A} 2 \mathrm{E}$, eye lipofuscin component, which starts to accumulate in pigment epithelium cells from the first visual cycle and the first sight. If we want to predict further AMD evolvement, it is very important to know lipofuscin primary accumulation over the first five years of life while the protective yellow spot and the ciliary muscle are developing.

In Figure 3 we can see age groups of patients examined in 1978. Patients were divided into two groups as per color temperature of a light environment which they were born in and spent their first five years of life.

The first group comprised people who were born and spent their first 5 years in a light environment with color temperature equal to $2700 \mathrm{~K}$ (a light source being an incandescent lamp with a small blue light dose).

The second group were people who were born in a light environment with color temperature being equal to $4000 \mathrm{~K}-6000 \mathrm{~K}$ (luminescent lamps with great blue light dose) and spent their first 5 years of life under luminescent and incandescent lamps.

Nowadays children are born in a light environment with color temperature being more than $4000 \mathrm{~K}$, and they spend their first 5 years of life with LED toys and LED visual display units. They all get increased blue light dose at early stages of their life, and, consequently, high accumulated lipofuscin level which causes risks of early AMD occurrence.

E. Kitchel and M. Ed give an overview of evolution stages in causes for increased risks of AMD occurrence and an excessive dose of blue light in the sunlight spectrum here is considered to be an indentified risk factor for cataract and AMD [18]. Thus, 838 boatmen in Chesapeake bay who spent most of their time under bright sunlight on the

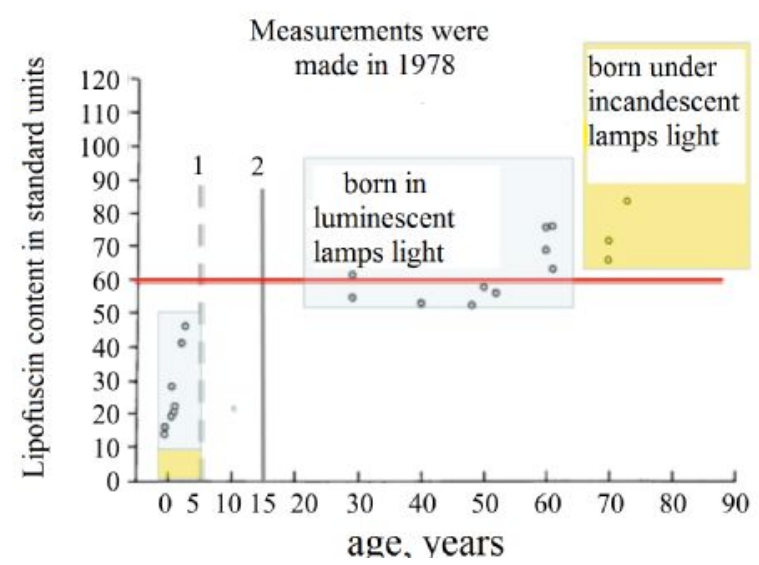

Figure 3. Lipofuscin content in overall RPE quantity depending on age [32]

(1: yellow spot develops by the age of 5, 2 is a moment when the ciliary muscle becomes fully developed).

water were examined, and scientists detected a significant correlation $(\mathrm{p}=0.05)$ between their work during previous 20 years and grave cataract and yellow spot degradation. Patients suffering from AMD were much more susceptible to blue light than people from control groups but they were equally susceptible to ultraviolet radiation $[13,18]$.

Eye grounds were examined in 5,000 people aged from 43 to 84 and it allowed to detect a correlation between time spent outdoors (during age periods 13-19 years and 30 -39 years from 13 to 19 and from 30 to 39) and both early and "late" AMD occurrence [31].

To detect a correlation between blue light influence and wet AMD in patients with lower antioxidants level, researchers examined 4,753 people aged 65 and older (Figure 4). The eye retina was photographed in all the examined people. Participants were also asked how much time they usually spent under exposure to sunlight and gave their blood for antioxidant analysis. Blue light measuring was assessed via combination of meteorological data and questioning [26].

4,753 people aged 65 and older took part in the following research and data on 
sunrays influence and antioxidants were available for 101 people with neovascular AMD among them and 218 with early AMD. The control group consisted of 2,117 people. Experts detected no correlations between blue light and neovascular or early AMD during the research. However, they detected a considerable dependence between blue light influence and a higher risk of wet AMD occurrence at low levels of vitamin $\mathrm{C}$, zeaxanthin, and vitamin $\mathrm{E}$, which were also related to early AMD stages with OR being about 1.4 or $40 \%$ [29]. Although it was impossible to detect causality between exposure to sunlight and neovascular AMD. Research results revealed that people in the general population should protect their eyes and follow the recommendations aimed at obtaining basic antioxidant nutrients.

Epidemiologists constantly argue over sunlight as a risk factor for yellow spot agerelated degeneration. Meta-analysis of 14 integrated research revealed that experts came to a conclusion on a higher AMD risk under exposure to sunlight in 12 of them (OD 1.379). In six works researchers reported on significant risks but some experts consider they are not proven properly and not validated [17]. Some authors think that natural blue filtration loss after cataract surgery can be related to higher AMD prevalence [31]. All the above-said proves that experts create their models to predict

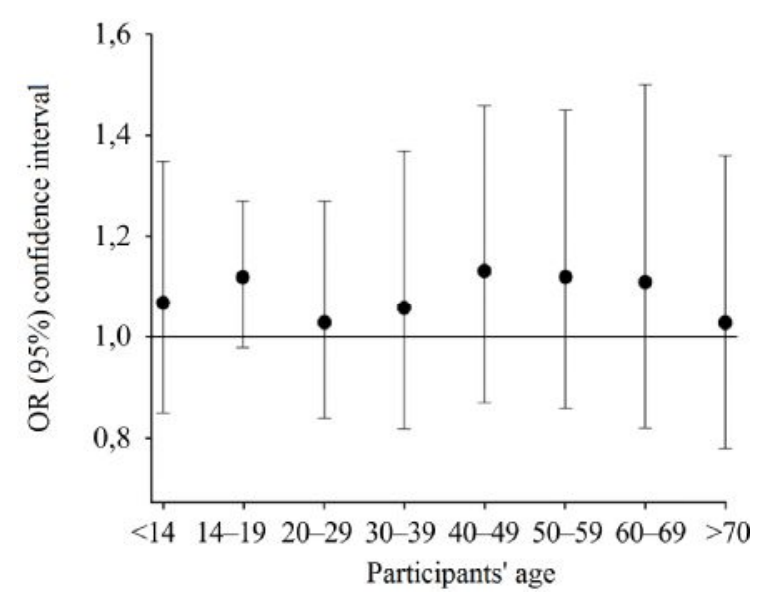

Figure 4. Odds ratio and confidence intervals of blue light exposure [29].
Characteristics of stages in age-related macular degeneration evolvement $[12,14,18,25,32]$

\begin{tabular}{|c|l|}
\hline Parameter & \multicolumn{1}{c|}{ Characteristics } \\
\hline $\begin{array}{c}\text { Time stages in } \\
\text { the process }\end{array}$ & $\begin{array}{l}\text { The overall human lifecycle is } \\
\text { divided into time stages as per } \\
\text { criteria determined by AMD pro- } \\
\text { cesses researchers }\end{array}$ \\
\hline $\begin{array}{c}\text { Stages particu- } \\
\text { larity and se- } \\
\text { quence }\end{array}$ & $\begin{array}{l}\text { Each stage is characterized with } \\
\text { its particular amount of A2E ac- } \\
\text { cumulated amount. Accumulation } \\
\text { rate is described with mathemati- } \\
\text { cal models on the basis of current } \\
\text { time stage peculiarities }\end{array}$ \\
\hline $\begin{array}{c}\text { The process } \\
\text { continuity }\end{array}$ & $\begin{array}{l}\text { Results of the previous stage are } \\
\text { the initial conditions for the next } \\
\text { stage. A2E accumulation at a cur- } \\
\text { rent stage is summed with A2E } \\
\text { amount accumulated at the previ- } \\
\text { ous time stage }\end{array}$ \\
\hline
\end{tabular}

AMD evolvement at each stage of a person life cycle and also note what factors play significant role in the risk of its occurrence (table). Analysis of various models and AMD evolvement mechanisms allowed to reveal common methodological approaches to their design. Bearing hygienic science interests in mind (which hygienic measures are necessary for preventing negative trends in this or that process?), we can suggest a model which illustrates that AMD risks (with various gravity) occur at younger ages.

Given the determined target function of the hygienic approach, a mathematic model describing A2E stage accumulation for AMD prediction can be given as follows:

$$
K_{\Sigma \mathrm{A} 2 \mathrm{E}}=\Sigma\left(A_{i}+B_{i} \Delta t_{i}\right),
$$

where $i-$ is a current stage number from the row: $1,2,3 \ldots$. ; $n$ - is a number of stages in a human lifecycle as per certain criteria (duration of being in a light environment of a maternity hospital, light environment at home, pre-school children facilities, school, educational establishments, working environment). From a hygienic point of view these criteria are: a) a time moment when protective elements in 
the visual analyzer structure are fully formed which is related to age peculiarities (yellow spot and the muscle system of the accommodation apparatus are fully formed and functional); b) a time moment when age-related degradation processes occur;;

$A_{i}-$ is $\mathrm{A} 2 \mathrm{E}$ amount accumulated by a moment when i-stage starts; it is calculated as per the following formula

$$
A_{i}=\Sigma\left(A_{i-1}+B_{i-1} \Delta t_{i-1}\right)
$$

$\Delta t_{i-1}-$ is an i-stage duration;

$B_{i}-$ is $\mathrm{A} 2 \mathrm{E}$ accumulation rate at an istage.

A2E evolvement generates active oxygen forms under exposure to blue light. Antioxidant protection efficiency is especially important at this stage (yellow spot formation for retina macula protection and superoxide dismutase efficient synthesis under exposure to excessive active oxygen forms). Thus, J.M. McCord et al. explains in his work that cells with insufficient superoxide dismutase content are extremely sensitive to oxygen intoxication [30].

Given all the above-stated, we suggest a model for predicting AMD evolvement at younger ages under exposure to excessive blue light dose in a light spectrum. This dose increases nowadays due to mass LED lighting implementation and its negative impacts only grow as it is installed now in maternity hospitals, pres-school children facilities, schools, at workplaces, and in private houses. The generalized model is given in Figure 5.

Potential functional resources of human organs are at least two times greater than our usual 60-80 years. But when hygienic rules are violated a human body degrades considerably faster in the contemporary environment. The brain can function for 200 years; eyes, lungs, and heart, up to 140 years; liver, up to 120 years; kidneys, up to 130 years; muscles, up to 150 year [8].

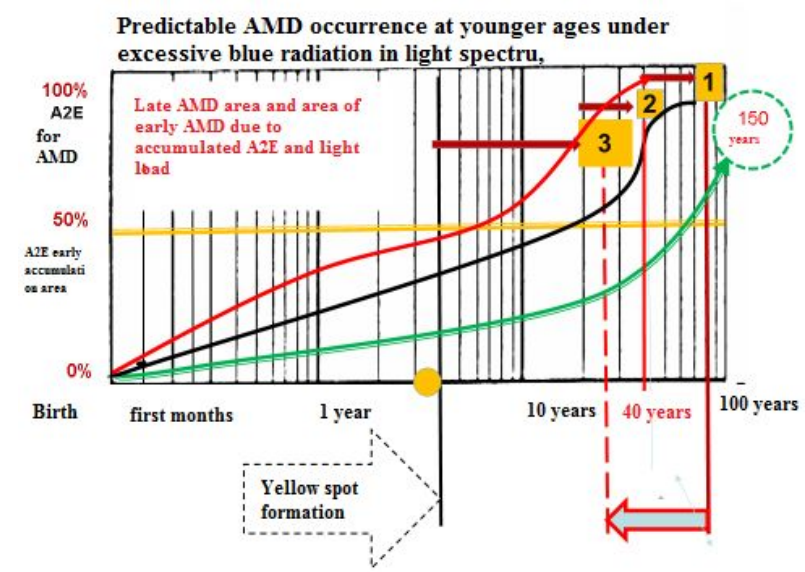

Figure 5. AMD occurrence rate.

A human body grows older because each its interaction with the environment causes a stress at this or that level. Stresses result in active oxygen forms which are to be compensated by antioxidant system.

Our model for A2E accumulation and predicting early AMD occurrence focuses on antioxidant system state as per its functional efficiency in a specific light environment. Mathematical models allowed for many influencing factors but they didn't contain calculations of antioxidant system state (superoxide dismutase and catalase) and its functional efficiency in a light environment created by artificial light sources with their spectra being different from the sunlight [12, $14,18,25,32]$. Let's expand on this point as it is important for getting better insight into AMD occurrence under LED light environment conditions.

Contemporary artificial lighting environment is created by lighting devices and visual display units. To detect regularities and crucial wave lengths (blue light doses) influencing the visual analyzed (A2E occurrence), we should consider overall spectra images of artificial light sources which create contemporary light environment (Figure $6)$.

As we can see from these graphs, all the contemporary artificial light sources have excessive radiation in blue light area (460 nanometers), a dip in blue-turquoise area (480 - 
500 nanometers), as well as absence of light (380 nanometers), which participate in the visual cycle and rhodopsin production out of vitamin A.

Nowadays LED lighting is being implemented without any approval from ophthalmologists but it is even more alarming that lighting with the same spectra is used in visual display units and its "cyanotic" light influences faces and eyes of almost all children in Russia. And while chief Russian ophthalmologists are keeping their silence,

LED lighting producers claim that, as per SCHEER experts, low-intensity radiation levels are below a threshold of possible
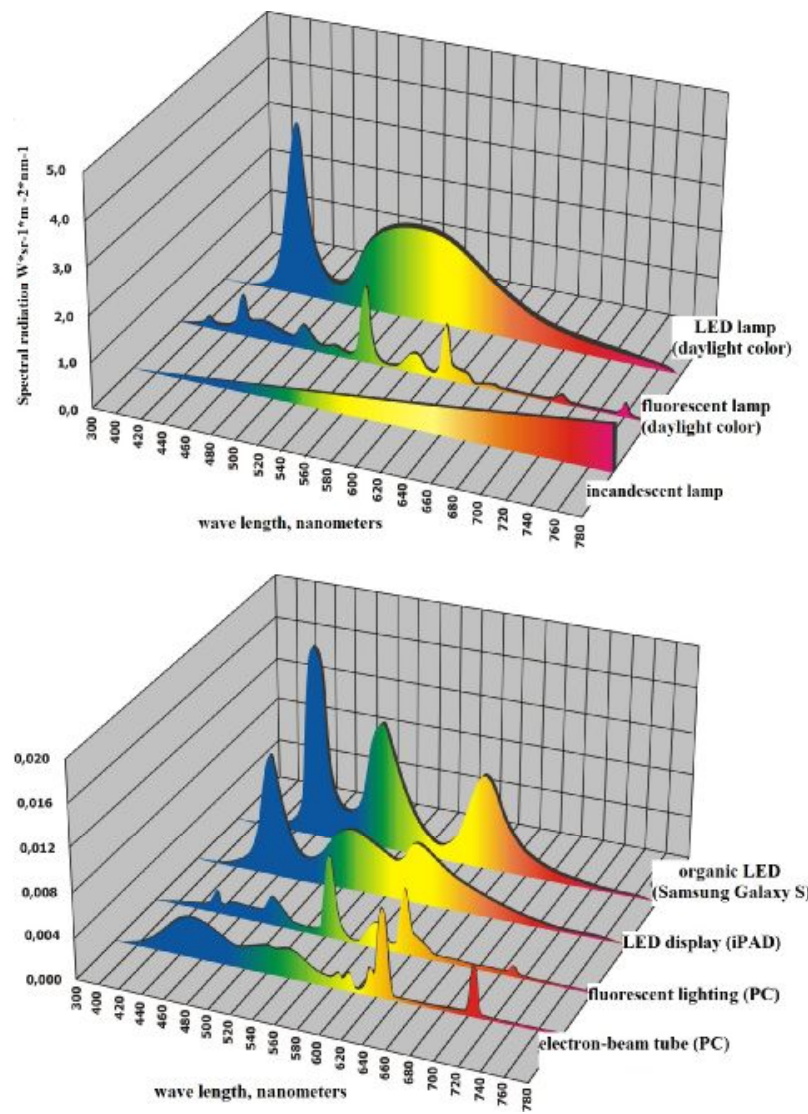

Figure 6. Overall light spectra images of various light devices. damage to the retina which is determined as per Icnirp Guidelines: On limits of exposure to laser radiation of wavelengths between 180 $\mathrm{nm}$ and $1,000 \mu \mathrm{m}^{2}$ and Icnirp Statement: On Light-Emitting Diodes (Leds) And Laser Diodes: Implications For Hazard Assessment ${ }^{3}$.

Nowadays Scientific Committee on Health, Environmental, and Emerging Risks (SCHEER) has published a preliminary report " Potential risks to human health of Light Emitting Diodes (LEDs)" dated July 6, $2017^{4}$. The section 6.5. "Basics of eye optics" contains the following conclusion: "Despite we don't have any reliable data for assessing risks to life safety when LED light sources are applied we can still be preoccupied with potential negative consequences caused by LED emissions especially in case of a susceptible population who already have early signs of the macula pathologic ageing. However, we should highlight that these problems arise due to the results obtained in experiments on animals or cells cultures models during which experts applied higher exposure levels than those which can possibly occur when LED light sources are used in everyday life. Impacts exerted by optical radiation coming from white LEDs can cause serious damage to the outer retina under high exposure levels. Spectral power distribution (SPD) and irradiation are risk factors which contribute into photochemical damage to the retina. To prevent this damage or to at least decrease it, one should use lower blue components for indoor lighting". The section 6.5.2.3 of the report titled "An eye posterior segment" contains the following experts' opinion: "A spectrum emitted by white LEDs has photons with energies which are higher than the enzymes threshold which

\footnotetext{
${ }^{2}$ Icnirp Guidelines:

On limits of exposure to laser radiation of wavelengths between $180 \mathrm{~nm}$ and $1,000 \mu \mathrm{m}$. Health Physics, 2013, Vol. 105, no. 3, pp. 271-295.

${ }^{3}$ Icnirp Statement: On Light-Emitting Diodes (Leds) And Laser Diodes: Implications For Hazard Assessment. Health Physics, 2000, vol. 78, no. 6, pp.744-752.

${ }^{4}$ Potential risks to human health of Light Emitting Diodes (LEDs): Preliminary Opinion. Scientific Committee on Health, Environmental and Emerging Risks (SCHEER). 6 July 2017. Available at: https://ec.europa.eu/ health/scientific_committees (10.09.2017).
} 
protect from stress ${ }^{\prime \prime}$.

Professor John Marshall in his new book "The Blue Light Paradox: Problem or Panacea", notes that:

- low-level long-term LED lighting (hours, days or months) causes damages to the retina;

- blue-violet light is more dangerous than other wave lengths;

- LEDs have high spectral peaks in blue range at levels which can exert cumulative impacts during human life;

- retina phototoxicity was shown in several research on wave lengths with high energy, blue-violet light, up to 455 nanometers [22].

Artificial light sources do exert malign impacts on the visual analyzer and it is clearly shown by new ophthalmologists' research on assessing myopia evolvement rate in countries where energy-saving lighting sources and computer technologies are implemented everywhere. Research performed in South Korea where compact luminescent and LED lamps are used everywhere had awful results: $96.5 \%$ of all the 19-year old men of call-up age suffered from myopia [24]. And it is only one step from myopia to early AMD occurrence as both these diseases evolve under low-intensive light. If light intensity doesn't do any damage to the retina, then "cyanotic" light spectrum can cause lower efficiency of the visual analyzer antioxidant protection.

Several researchers revealed that lowtemperature $4,000 \mathrm{~K}$ LED light is equal to $6,500 \mathrm{~K}$ sunlight as per blue light dose [7]. Visual display units with $7,000 \mathrm{~K}$ LED lighting are equal to $1,000 \mathrm{~K}$ sunlight as per blue light. M.A. Ostrovskiy, the Russian Academy of Sciences Member (N.M. Emmanuel's RAS Biochemical Physics Institute) describes these processes as an eye-sight pho- tobiological paradox which is that light carries visual information and is simultaneously a risk factor [6]. A combination of light and oxygen is a necessary condition for normal photoreceptor process functioning. But at the same time these are classic conditions, necessary and sufficient for occurrence and evolvement of destructive photochemical reactions in eyes structures as per free radical oxidation mechanism.

In M.A. Ostrovskiy's opinion, it is correct to spot out two functional eye systems: photoreception itself and protection from photo-damage danger. Focusing on an eyesight photobiological paradox, we should point out that retinal is a key section in both photoreception and light damaging mechanisms. the visual cycle shown in Figure 7 underlies visual processes.

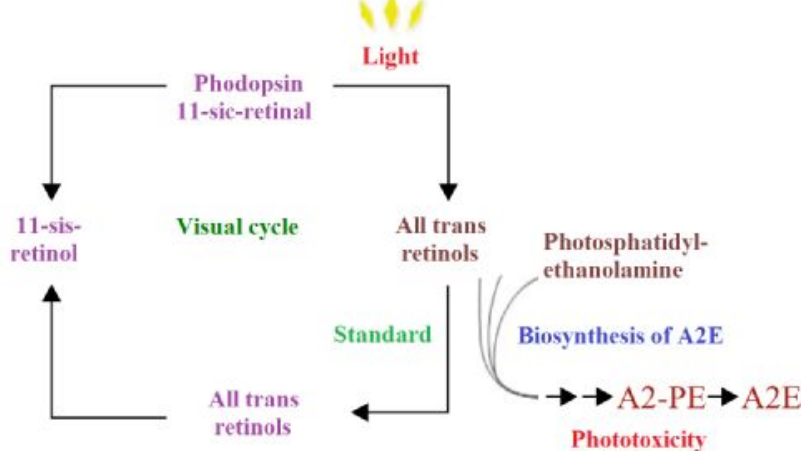

Figure 7. Visual cycle and photopathy danger

The visual cycle completely removes trans-retinal out of the photoreceptor membrane and then returns it back there but in 11-sic isomer form (Figure 7). Only this isomer is able to penetrate the chromophore center in a molecule protein section (opsin) and again create a covalent chemical bond with 296-lysine amino-acid residue in its seventh $\alpha$-helix. All the above-said explains how rhodopsin regenerates, that is, returns

\footnotetext{
${ }^{5}$ Potential risks to human health of Light Emitting Diodes (LEDs): Preliminary Opinion. Scientific Committee on Health, Environmental and Emerging Risks (SCHEER). 6 July 2017. Available at: https://ec.europa.eu/health/ scientific committees/scheer/opinions en\#fragment1 (10.09.2017).
} 
into its initial dark state with maximum optical photons absorption at a wave length equal to 500 nanometers and other lengths in the blue-turquoise spectrum part. Photon flux has a dip (minimal value at 500 nanometers) in this wave lengths range in case of LED light in comparison with the sunlight. Rhodopsin regeneration cycle is one of the key events in the retina dark adaptation process [6].

P.P Zak together with M.A. Ostrovskiy note that "Visual cycle results in so called A2E-phosphatidylethanolamine (A2EPE) formation in the membrane. Apparently, it is phototoxic by itself, but what is more important, it is just a predecessor of the next extremely toxic compound, namely pyridinium bisretinoid or A2E for short" [4]. Under exposure to blue light ( $<455$ nanometers) this phototoxic compound, A2E, generates active oxygen forms. Phototoxicity mechanisms and a significant role which blue light plays in them are described in depths in M.A, Ostrovskiy's works.

The retina is a medium with great oxygen strain close to $70 \mathrm{~mm} \mathrm{Hg} \mathrm{[11],} \mathrm{and} \mathrm{it}$ creates perfect conditions for ROS oxidative stress evolvement (damage done to a cell due to oxidation). A spectrum (blue/turquoise balance) starts up the visual cycle during which rhodopsin decays and recovers with certain efficiency and A2E phototoxic compound occurs as a phosphor of lipofuscin granules which accumulate in pigment epithelium tissue culture. Under exposure to blue light and having reached certain concentrations, A2E is able to, on the one hand, develop detergent properties when it, for example, damages the outer mitochondrial membranes and activates cells apoptosis, and, on the other hand, to act as a photosensitizer of cell free-radical damage which can also led to its apoptosis. This paradox of light being both an information carrier and a potentially dangerous damaging factor, was solved as a sufficiently reliable multi-level system which protects against photopathy was created in the process of evolution. This system includes:

- photoreceptor membranes renewal;

- a set of endogenous antioxidants;

- a mechanism for the promptest free retinal removal out of a visual cell;

- eye optical filters system with a key role in it belonging to the lens which yellows with age in human and primates' eyes.

The next protection line is antioxidant. It includes vitamins $\mathrm{E}$ ( $\alpha$-tocopherol) and $\mathrm{C}$ (ascorbic acid), taurine, several antioxidant enzymes (superoxide dismutase, catalase, and peroxidase). Eye shielding pigments, or melanosomas, enhance this effect. A melanosoma is an organelle which consists of melanin and other light-absorbing pigments.

Superoxide dismutase transforms active oxygen forms into hydrogen peroxide and then catalase transforms it into water. Undoubtedly, any disorders in the system "light spectrum - rhodopsin - antioxidant system" cause increased risks of light damage to the retina and pigment epithelium. SCHEER reports, section 6.5.2.3 "Posterior eye segment" contains experts' opinion that "a spectrum emitted by white LEDs has photons with energies higher than enzymatic threshold which protects from stress" ${ }^{6}$. We can also find a comprehensive analysis there which dwells on potential risks caused by white LEDs allowing for pre-clinic knowledge as well as epidemiologic research and reports by the French Agency for Preventing potential hazards for the retina via three systems [21]:

1) non-enzymatic molecules such as thiols, vitamins (E and $\mathrm{C}$ ), carotinoids (vitamin

\footnotetext{
${ }^{6}$ Potential risks to human health of Light Emitting Diodes (LEDs): Preliminary Opinion. Scientific Committee on Health, Environmental and Emerging Risks (SCHEER). 6 July 2017. Available at: https://ec.europa.eu/health/ scientific_committees/scheer/opinions_en\#fragment1 (10.09.2017).
} 
A);

2) metals ions absorbers;

3) specific enzymes such as superoxide dismutase (SOD) and catalase.

Superoxide dismutase (SOD) molecules can be found in all living cells exposed to oxygen-containing environment including epithelial retina cells (retinal pigment epithelium or RPE). Pigment epithelium in the human retina contains two different superoxide dismutase types [24]. Both $\mathrm{CuZn}$ - and Mn-containing SOD play their own role and can contribute greatly into removal of superoxide radicals which evolve in mitochondrias as an oxygen metabolism by-product [23].

1. Cytoplasmic (or cytosolic) superoxide dismutase (or SOD-1). It functions inside cells. A gene which is responsible for cytoplasmatic superoxide dismutase synthesis is located in the $21 \mathrm{st}$ chromosome, in $21 \mathrm{q} 22.1$ locus.

2. Mitochondrial superoxide dismutase (SOD-2). It is located in the mitochondrial matrix. A gene responsible for its synthesizing and functioning is in the 6th chromosome, 6q25.3 locus.

3. Extracellular superoxide dismutase (SOD-3). It can be found in the intercellular substance; a gene responsible for its synthesis and functioning is located in the 4th chromosome, 4p15.3-p15.1 locus.

Superoxide dismutases keep steady-state concentration of superoxide radicals at a certain level thus protecting cellular structures from their hazardous impacts. SOD-1 is in cytoplasm, SOD-2, in mitochondrias, and SOD-3 is an extracellular (intercellular) type. The first type is dimeric, while the two others are tetrameric (consisting of 4 equal sub-units). SOD-1 and SOD-2 contain copper in their active center and zinc as their structural component, while SOD-2 contains manganese in its active center. Genes responsible for these types are located correspondingly in the chromosomes 21,6 and 4 (21q22.1, 6q25.3 and 4p15.3-p15.1). Cytoplasmic SOD-1 is a small protein with mo- lecular weight $32.5 \mathrm{kDa}$, but molecular weight of mitochondrial SOD-2 is about 86$88 \mathrm{kDa}$. Extracellular SOD is the greatest superoxide dismutase, its molecular weight being $135 \mathrm{kDa}$.

As Hassan and Fridovich detected in 1977, enhanced superoxide dismutase synthesis occurred under increased facultative organisms exposure to oxygen when there was excessive peroxide radicals evolvement inside a cell. Intracellular superoxide dismutase concentration correlates with a cell resistance to oxygen intoxication [15].

A reaction catalyzed by SOD consists of two stages and involves transfer of an electron from one superoxide radical to another. A copper atom located in the SOD active center is an intermediate acceptor for this electron:

$$
\begin{gathered}
\text { СОД- } \mathrm{Cu}^{2+}+\mathrm{HO}^{*}=>\mathrm{CO}-\mathrm{Cu}^{+}+\mathrm{O}_{2} \\
\text { СОД-Cu}+\mathrm{HO}^{2 *}=>\mathrm{CO}-\mathrm{Cu}^{2+}+\mathrm{H}_{2} \mathrm{O}_{2} .
\end{gathered}
$$

Hydrogen peroxide $\left(\mathrm{H}_{2} \mathrm{O}_{2}\right)$ is a basic source of the most toxic radicals in living systems, namely $\mathrm{HO}$ radicals. So, decrease in $\mathrm{H}_{2} \mathrm{O}_{2}$ will lead to lower $\mathrm{HO}$ radicals concentrations. $\mathrm{H}_{2} \mathrm{O}_{2}$, is removed by two enzymes: catalase and peroxidase.

Catalase enzyme cycle consists of the following stages:

$$
\begin{gathered}
\text { Cat-Fe }{ }^{3+}+\mathrm{H}_{2} \mathrm{O}_{2}=>\text { Cat-Fe }{ }^{5+}+2 \mathrm{H}_{2} \mathrm{O} \\
\text { Cat-Fe } \mathrm{Fe}^{5+}+\mathrm{H}_{2} \mathrm{O}_{2}=>\text { Cat-Fe }{ }^{3+}+\mathrm{O}_{2} .
\end{gathered}
$$

Experts from the Institute for Biophysics and Cellular Engineering of the Belarus National Academy of Science assessed influence exerted by blue light on superoxide dismutase (SOD) activity and revealed that this activity aimed at active oxygen forms compensating in cells was significantly inhibited by it [3].

Figure 8 shows ranked results of the research. These data prove that photom flux in blue light range $(450-465 \mathrm{~nm})$ exerts significant influence on (SOD) activity aimed at active oxygen forms neutralization. Superoxide dismutase (SOD) activity grows drastically under irradiation by light coming from a spectrally managed LED lamp with 
blue+light blue $(465-485 \mathrm{~nm})+$ yellow + red LEDs in its structure. As color temperature grows, superoxide dismutase (SOD) activity decreases.

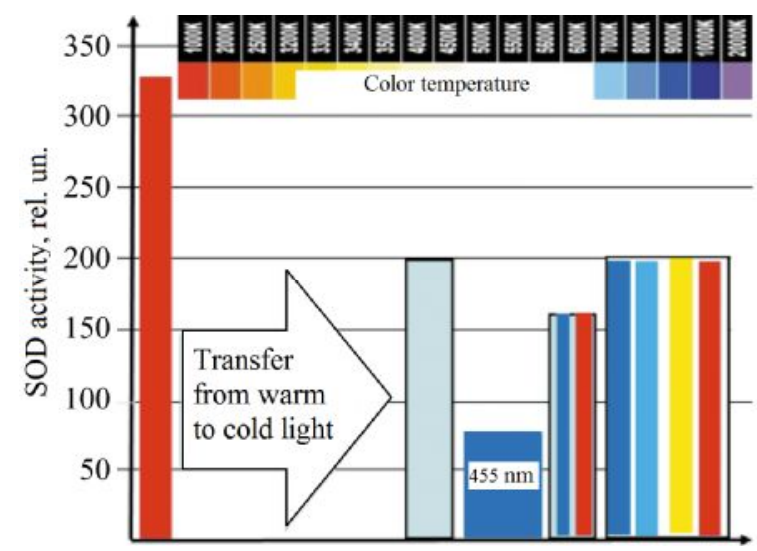

Figure 8. Changes in overall SOD activity in an organic object under lighting:

red LED 630nm-650nm; white light from lu-

minescent lamp Philips TL-D36W/765

(6200K); blue LED 450nm-465nm; blue + red LEDs; blue + light blue (465nm-485nm) + yellow $(590 \mathrm{~nm}-595 \mathrm{~nm})+$ red LEDs.

Experiments made on laboratory animals are also interesting. Thus they revealed that if mice had SOD-2 deficiency, A2E level and lipofuscin accumulated in their RPE were high [28]. Some experts think SOD-2 is likely to play a positive role in early AMD prevention as it protects a mouse pigment epithelium from apoptosis caused by oxidation [27].

On May 1-5, 2016 at ARVO annual meeting in Seattle, Washington, there was a report entitled "Blue light decreases oxidative stress defenses in an in vitro model of AMD" [10]. Experts applied a specially designed lighting system which provided 10 $\mathrm{nm}$ wide lighting ranges in a blue-green range; they revealed that a narrow 415-455 $\mathrm{nm}$ range was the most toxic for EE-loaded RPE cells and was a sign of high oxidative stress (damage to a cell caused by oxidation). To get further insight into mechanisms related to this phototoxicity, experts then ex- amined photomodulation of basic oxidative stress protections in the blue-green range of the visible spectrum. Light irradiation was standardized as per natural sunlight $(6500 \mathrm{~K})$ which reached the retina after it had been filtrated by ocular structures $\left(\mathrm{E}_{\max }<1.5 \mathrm{~mW}\right.$ $/ \mathrm{cm}^{2}$ ).

When this AMD model was applied in vitro, it was detected that antioxidant protection deteriorated after exposure to blue light and it could make for concomitant increase in active oxygen forms quantity. These results prove that blue light can act as ROS inductor and ROS elimination process inhibitor which will result in greater oxidative stress and, consequently, cells death. These results give better knowledge needed for preventing oxidative stress caused by blue light during retina photo-adjustment and AMD.

Figure $9(\mathrm{a}, \mathrm{b}, \mathrm{c}, \mathrm{d}$, and e) shows generalized results of influence exerted by blue light on:

- hydrogen peroxide from A2E concentration;

- mitochondria potential;

- superoxide dismutase (SOD-2);

- catalase;

- glutathione peroxidase 1, also known as GPX1.

Glutathione peroxidase functions at hydrogen peroxide detoxification and is one of the most important human antioxidant enzymes; it is expressed everywhere in many tissues where it protects cells from oxidative stress. It is located inside cells, in cytoplasm and mitochondrias and catalyzes reduction of other organic hydroperoxides such as lipid peroxides, to corresponding spirits. GPX1 usually uses glutathione (GSH) as a reducing agent, but glutathione synthetase (GSS), just as in cerebral mitochondrias, can also act as a reducing agent instead of $\gamma$ glutamylcysteine. A protein coded by this gene protects from CD95-inducted apoptosis in cultivated breast cancer cells and inhibits 5-lipoxygenase in blood cells, and its 


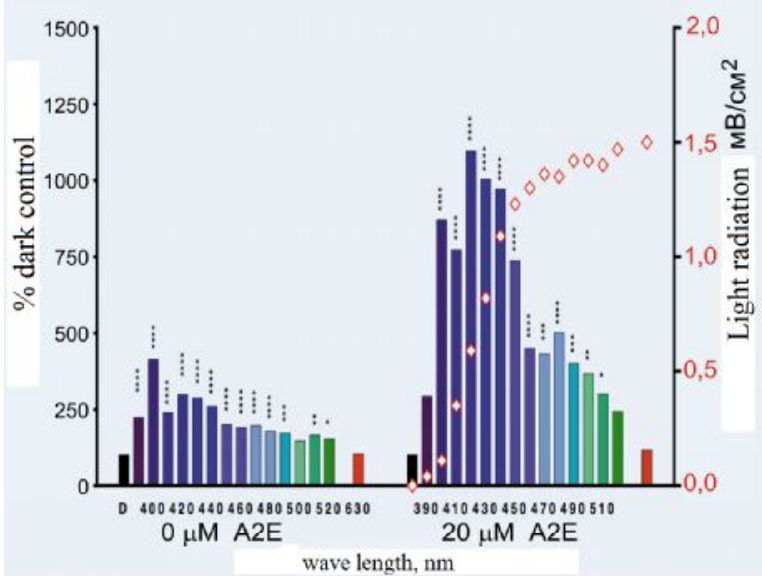

$a$

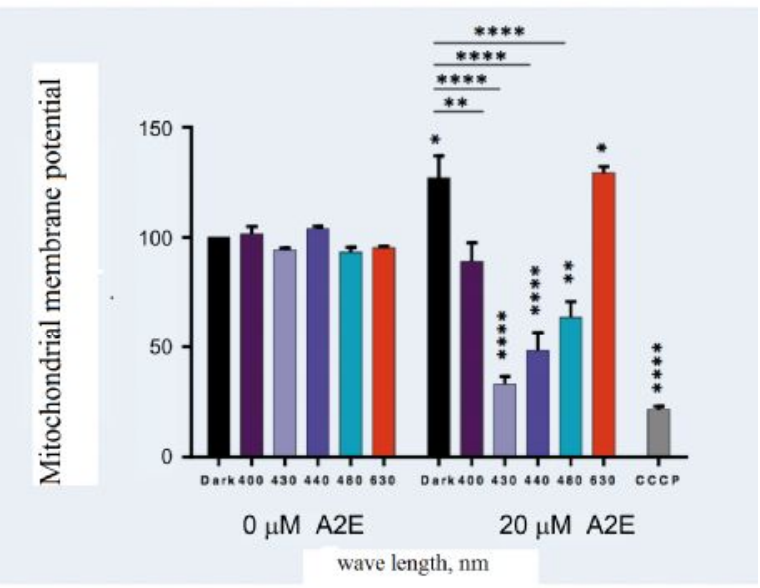

$b$

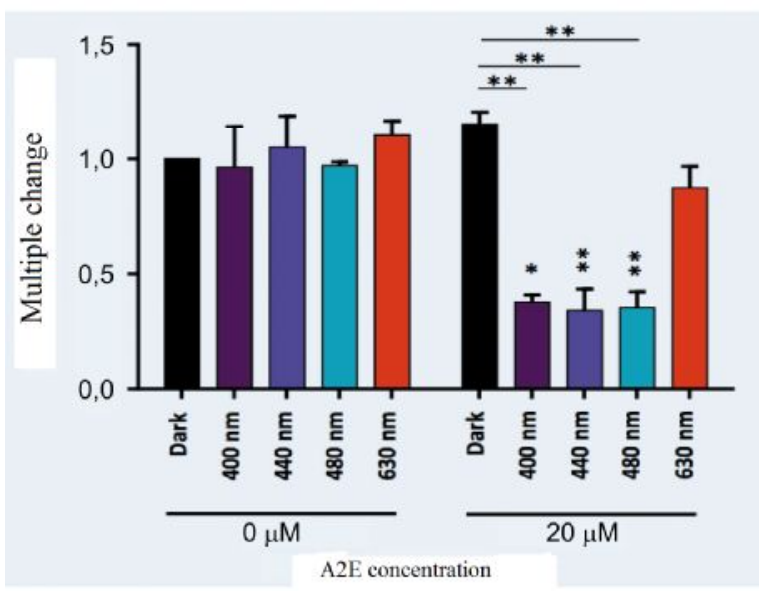

$c$
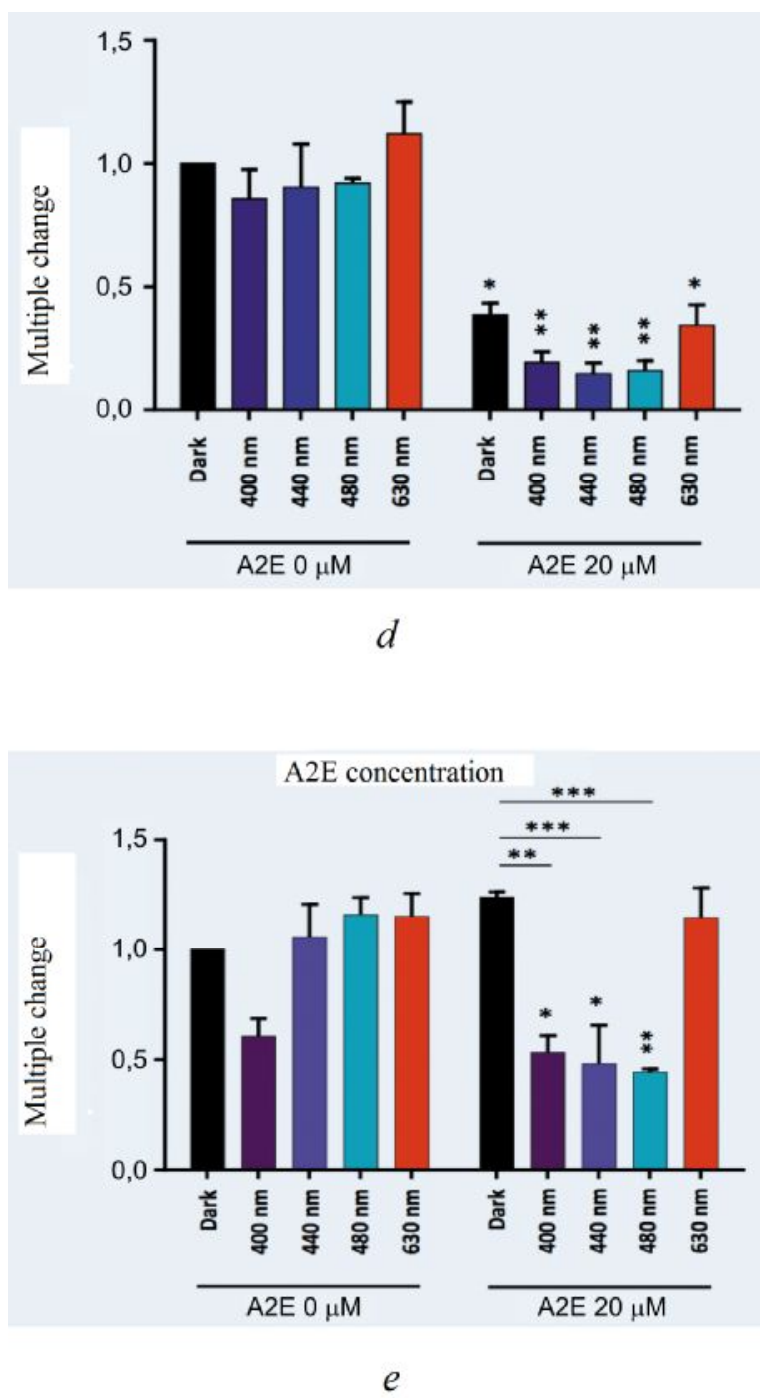

Figure 9 (a, b, c, d, and e). Influence exerted by blue light on hydrogen peroxide from $\mathrm{A} 2 \mathrm{E}$ concentration; mitochondrial potential; superoxide dismutase (SOD-2); catalase; glutathione peroxidase 1: $a$ - high hydrogen peroxide content was detected in blue-violet spectrum after 15-hour irradiation with A2E presence in comparison with dark control and red lighting, especially between $415-455 \mathrm{~nm}$ (average \pm s.e.m, $\mathrm{n}=4) ; b$ - mitochondrial membrane potential decerased significantly after blueviolet light impacts at $440 \mathrm{~nm}$ in cells loaded with A2E (average \pm s.e.m, $\mathrm{n}=3$ ); $c$ - Low

SOD-2 antioxidant protection expression СОД-2; $d$ - catalase; $e$ - glutathione peroxidase-1 
excessive expression postpones endothelial cells death and increases resistance to toxic problems, especially oxidative stress.

Lower SOD-2 mRNA, catalase, and GPX1 expression was observed after 15-hour exposure to blue light in cells loaded with $\mathrm{A} 2 \mathrm{E}$ in comparison with untreated control elements or cells loaded with A2E which were exposed to red light (average \pm s.e.m, $n=3$ ).

Peri-nuclear clustering and globular forms were observed in mitochondrias of cells irradiated with blue-violet light (430-400nm) and their membrane potential became significantly lower in RPE cells falling down to nearly mitochondrial dysfunction. Low expression of basic antioxidant enzymes was detected after exposure to blue light at $\mathrm{A} 2 \mathrm{E}$ presence, and high hydrogen peroxide content was detected in cells exposed to blue light between 415 and 455 $\mathrm{nm}$, and it allows to consider blue light an indentified AMD risk factor.

O.V. Basharina states in her work that impacts exerted by ultraviolet light (240-390 $\mathrm{nm})$ in specific doses (4.5-15.1) * $10^{2} \mathrm{~J} / \mathrm{m} 2$ at $\mathrm{pH} 6.3,(1, .5-45, .3) * 10^{2} \mathrm{~J} / \mathrm{m} 2$ at $\mathrm{pH} 9.0$ and $(1.5-\mathrm{i}-22,6) * 10^{2} \mathrm{~J} / \mathrm{m} 2$ at $\left.\mathrm{pH} 11.5\right)$ cause higher superoxide dismutase activity. greater ultraviolet light doses induce the enzyme inactivation [1].

Analysis of all the above-mentioned data proves that antioxidant protection (superoxide dismutase) reaches its maximum efficiency under certain light doses and when this level is exceeded, metalcontaining protective enzymes become inactive.

So, spectral structure of the environment adults and children live in can have significant influence on early AMD occurrence risks and other eye diseases risks.

Excessive blue light dose is a difference between doses under LED lighting against hygienically safe sunlight at a preset lighting level. Given all the detected drawbacks in white LEDs (a blue crystal covered with yellow phosphor) and their negative influence on the human visual analyzer [7], no wonder, that Russian experts have already designed a concept of semi-conductor white light sources with a biologically adequate radiation spectrum.

A biologically adequate light spectrum is a set of photon fluxes which form a controlling signals matrix providing harmonized functioning of the visual analyzer cells, human hormonal system, and normal brain functioning.

Biologically adequate lighting environment is an environment created by semiconductor white light sources with a biologically adequate light spectrum aimed at minimizing human health risks at all the stages in his or her life cycle. This definition is created on the basis of all the above-stated and working experience in formulating scientific grounds for the design of semi-conductor white light sources with biologically adequate light spectrum. As experts from "ELTAN" Ltd worked on a project " Development of an industrial technology for manufacturing energy-efficient LED white light sources with biologically adequate radiation spectrum", they synthesized a white light spectrum without any peaks within $460 \mathrm{~nm}$ range and dips within $480 \mathrm{~nm}$ range. Figure 10 shows a measured spectrum of the designed lamp.

This spectrum doesn't have any drawbacks detected in a standards white LED spectrum. The developed technology is protected by patents issued in Russia, Europe, Korea, the USA, and China, and it has made foreign LED manufactures to increase quality of light coming from their LEDs. And countries where teenagers myopia has the highest levels have reached certain success in synthesizing semi-conductor white light emitters with a spectrum which is equal to a spectrum of hygienically safe sunlight.

This spectrum doesn't have any drawbacks detected in a standards white LED spectrum. The developed technology is protected by patents issued in Russia, Europe, Korea, the USA, and China, and it has made 


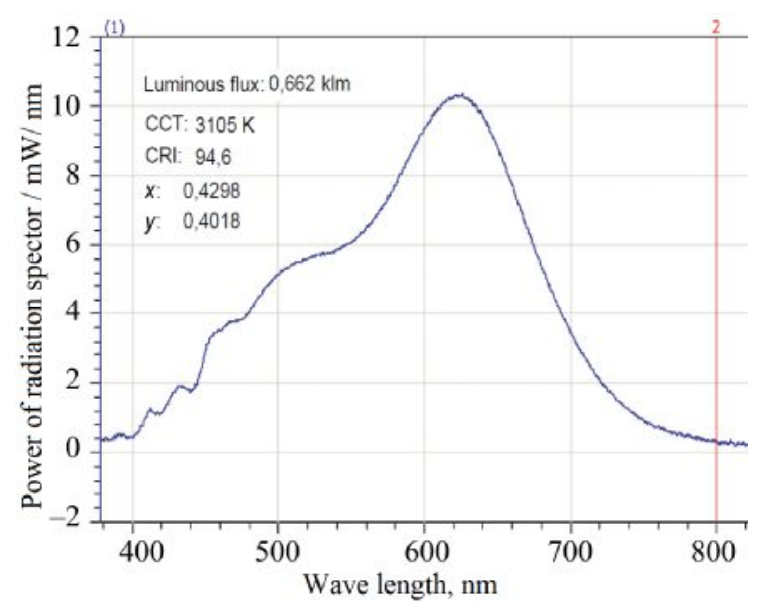

Figure 10. A light spectrum of a semiconductor source with biologically adequate white light spectrum $-3105 \mathrm{~K}$, designed by "ELTAN" Ltd experts.

foreign LED manufactures to increase quality of light coming from their LEDs. And countries where teenagers myopia has the highest levels have reached certain success in synthesizing semi-conductor white light emitters with a spectrum which is equal to a spectrum of hygienically safe sunlight. LEDs belonging to the second generation and developed in Japan and Korea (with blue light dips and peaks in their spectrum not exceeding parameters of hygienically safe sunlight) are now penetrating European light techniques market. EuroLighting GmbH (Germany) increases its activities in selling ALLIX LEDs manufactured in Korea. White LEDs with sunlight spectrum are protected with patents in Europe, Korea, the USA, and China. This new LED is available in two ranges: Xenoled I and Xenoled II. The difference between them is that Xenoled I has a blue chip as its base but LEDs from Xenoled II range employ a crystal which emits violet light and phosphors of many colors. These SMD LEDs have high CRI up to 98, and there are no blue peaks in their spectrum within 450nm-460nm and dips within $480 \mathrm{~nm}$ range (Figure 11).

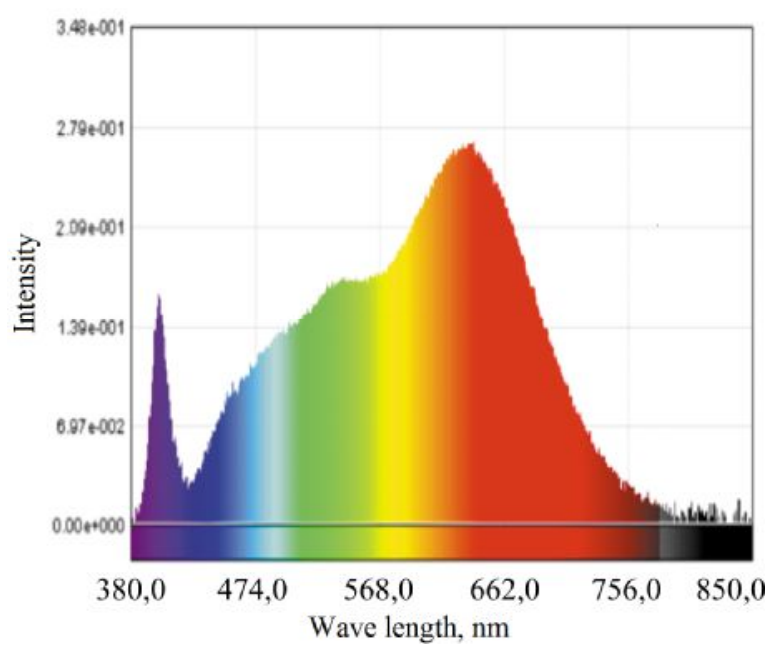

Figure 11. White light spectrum at $3000 \mathrm{~K}$ emitted by a LED from Xenoled II range.

A peak occurrence in the spectrum of the LEDs from Xenoled II range requires providing additional constructional protection in the LED lamp. But all in all LEDs from this range emit almost sunlight and blue peaks hazard is significantly reduced in them. Semi-conductor light sources which emit white light with a biologically adequate spectrum can be applied as light sources creating healthy lighting environment for children and adults provided that they are given relevant hygienic certificates with ophthalmologists participating in the procedure.

Conclusions: 1 . To make advance predictions for early AMD occurrence risks it is advisable to create mathematical models aimed at assessing safety of new artificial light sources which are to be installed in educational and medical facilities. 2. Existing mathematical models for predicting A2E eye lipofuscin level don't allow for impacts exerted by blue light on antioxidant protection efficiency and color temperature of the lighting environment starting from birth and over the first 5 years of life. 3 . We should allow for peculiarities and a period of being in a lighting environment with various artificial sources which differ as per spectra and color temperature when we create a set of prevention activities for people from different age groups. 4. Mass implementation of LED 
lighting and visual display units with lighting having excessive blue light dose with peaks within $450 \mathrm{~nm}-460 \mathrm{~nm}$ range and dips within $480 \mathrm{~nm}$ range will lead to greater risks of AMD occurrence by the age of 30-
40 years already, and it in its turn will cause greater expenses of state budgets in the nearest future due to population disability related to eye diseases and eyesight loss.

\section{References}

1. Basharina O.V., Artyukhov V.G. Analiz fotoindutsirovannykh strukturno-funktsional'nykh izmenenii superoksiddismutazy [Analysis of photo-induced structural-functional changes in superoxide dismutase]. I Vserossiiskaya konferentsiya fotobiologov: tezisy doklada na konferentsii. Pushchino, ONTI, Publ., 1996, pp. 62-63 (in Russian).

2. Bolbas Z.V., Vasilevskaya N.A., Chikun E.A. Vozrastnaya makulyarnaya degeneratsiya: faktor rosta endoteliya sosudov VEGF, shaperon RPE65 i retseptory semeistva ppar kak perspektivnye misheni lekarstvennoi terapii [Age-related macular involution: vascular endothelium growth factor VEGF, chaperone RPE65 and receptors of PPAR family as perspective targets of pharmacological therapy]. Internet sessiya: vserossiiskaya obrazovatel'naya internetprogramma dlya vrachei, 2011. Available at: https://internist.ru/publications/detail/vozrastnayamakulyarnaya-degeneraciya:-faktor-rosta-endoteliya-sosudov-vegf,-shaperon-rpe65-ireceptory-semeystva-ppar-kak-perspektivnye-misheni-lekarstvennoy-terapii/ (18.04.2017) (in Russian).

3. Vyazov E.V., Shalygo N.V. Vliyanie spektral'nogo sostava svetodiodnogo izlucheniya na aktivnost' antioksidantnykh fermentov i nakopleniya zashchitnykh belkov $\mathrm{v}$ rasteniyakh ogurtsa [Effect of the spectral composition of LED lighting on the activity of antioxidant enzymes and the defensive protein content in cucumber plants (Cucumis sativus L.) ]. Doklady natsional'noi akademii nauk Belorusi, 2015, vol. 59, no. 2, pp. 87-92 (in Russian).

4. Zak P.P., Ostrovskii M.A. Potentsial'naya opasnost' osveshcheniya svetodiodami dlya glaz detei i podrostkov [Potential danger of light emitting diode illumination to the eye, in children and teenagers]. Svetotekhnika, 2012, no. 3, pp. 4-6 (in Russian).

5. Kaptsov V.A., Deinego V.N. Sinii svet svetodiodov - novaya gigienicheskaya problema [Blue LED light as a new hygienic problem]. Health Risk Analysis, 2016, no. 1, pp. 15-25. DOI: 10.21668/health.risk/2016.1.02.eng (in Russian).

6. Ostrovskii M.A. Fotobiologicheskii paradoks zreniya [Photo-biological eyesight paradox]. Available at: http: //www.library.biophys.msu.ru/PDF/3353.pdf (17.08.2017) (in Russian).

7. Deinego V.N., Kaptsov V.A., Balashevich L.I., Svetlova O.V., Makarov F.N., Guseva M.G., Koshits I.N. Profilaktika glaznykh zabolevanii u detei i podrostkov v uchebnykh pomeshcheniyakh so svetodiodnymi istochnikami sveta pervogo pokoleniya [Prevention of ocular diseases in children and teenager in classrooms with led light sources of the first generation]. Rossiiskaya detskaya oftal'mologiya, 2016, no. 2, pp. 57-72 (in Russian).

8. Smagin V.A. Gerontologiya i teoriya nadezhnosti o dolgovechnosti cheloveka [Gerontology and reliability theory on human durability]. Kompaniya otkrytykh sistem. Available at: http: //sir35.narod.ru/Cmagin/K015/Ger.htm (12.05.2017) (in Russian).

9. Sokolov A.V. Izuchenie vozdeistviya produktov zritel'nogo tsikla na bisloinye lipidnye membrany: dis. ... kand. biol. nauk: 03.00.02 [Research on effects exerted by visual cycle products on bi-layer lipid membranes: Thesis ... Candidate of Biological Sciences: 03.00.02]. Moscow, 2009, 143 p. (in Russian).

10. Marie M., Barrau C., Gondouin P., Villette Th., Cohen-Tannoudji D., Sahel J., Picaud S. Blue light decreases oxidative stress defenses in an in vitro model of AMD. Available at: 
https://www.google.ru/url?sa=t\&rct=j\&q=\&esrc=s\&source=web\&cd=4\&ved=0ahUKEwjToM maqd7XAhWIHpoKHRMMAskQFghDMAM\&url=http $\% 3 \mathrm{~A} \% 2 \mathrm{~F} \% 2 \mathrm{Fwww}$.pointsdevue.com $\%$ 2Fsites\%2Fdefault\%2Ffiles\%2Fposter-arvo-2016.pdf\&usg=AOv

Vaw0zmMf5q4uBHkebESmEebMH (18.06.2017).

11. Boulton M., Rozanowska M., Rozanowski B. Retinal photodamage. Journal of Photochemistry and Photobiology, 2001, vol. 64, no. 2-3, pp. 144-161.

12. Delori F.C., Goger D.G., Dorey C.K. Age-Related Accumulation and Spatial Distribution of Lipofuscin in RPE of Normal Subjects. Investigative Ophthalmology \& Visual Science, 2001, vol. 42, no. 8, pp. 1855-1866.

13. Taylor H.R., West S.K., Rosenthal F.S., Munoz B., Newland H.S., Abbey H., Emmett E.A. Effect of Ultraviolet Radiation on Cataract Formation. The New England Journal of Medicine, 1988, vol. 319, pp. 1429-1433. DOI: 10.1056/NEJM198812013192201

14. Ersoy L., Ristau T., Hahn M., Karlstetter M., Langmann T., Droge K., Caramoy A., den Hollander A.I., Faus S. Genetic and Environmental Risk Factors for Age-Related Macular Degeneration in Persons 90 Years and Older. Investigative Ophthalmology \& Visual Science, 2014, vol. 55, no. 3, pp. 1842-1847. DOI: 10.1167/iovs.13-13420.

15. Hassan H.M., Fridovich I. Regulation of the synthesis of superoxide dismutase in Escherichia coli. Induction by methyl viologen. J. Biol. Chem., 1977, vol. 252, no. 21, pp. 76677672.

16. Newsome D.A., Dobard E.P., Liles M.R., Oliver P.D. Human retinal pigment epithelium contains two distinct species of superoxide dismutase. Investigative Ophthalmology \& Visual Science, 1990, vol. 31, pp. 2508-2513.

17. Guo-Yuan Sui, Guang-Cong Liu, Guang-Ying Liu, Yan-Yan Gao, Yan Deng, Wen-Ying Wang, Shu-Hui Tong, Lie Wang. Is sunlight exposure a risk factor for age-related macular degeneration? A systematic review and meta-analysis. British Journal of Ophthalmology, 2013, vol. 97, no. 4. Available at: http://bjo.bmj.com/content/97/4/389 (07.07.2017).

18. Kitchel E., Ed M. The Effects of Blue Light on Ocular Health. Texas School for the Blind and Visually Impaired. Available at: http: //www.tsbvi.edu/instructional-resources/62family-engagement/3654-effects-of-blue-light (26.06.2017).

19. Ablonczy Z., Higbee D., Anderson D.M., Dahrouj M., Grey A.C., Gutierrez D., Koutalos Y., Schey K.L., Hanneken A., Crouch R.K. Lack of Correlation Between the Spatial Distribution of A2E and Lipofuscin Fluorescence in the Human Retinal Pigment Epithelium. Investigative Ophthalmology \& Visual Science, 2013, vol. 54, no. 8, pp. 5535-5542.

20. Lamb L.E., Simon J.D.. A2E: A Component of Ocular Lipofuscin. Photochemistry and Photobiology, 2004, vol. 79, no. 2, pp. 127-136.

21. Behar-Cohen F., Martinsons C., Viénot F., Zissis G., Barlier-Salsi A., Cesarini J.P., Enouf O., Garcia M., Picaud S., Attia D. Light-emitting diodes (LED) for domestic lighting: Any risks for the eye? Prog. Retin. Eye. Res., 2011, vol. 30, no. 4, pp. 239-257. DOI: 10.1016/j.preteyeres.2011.04.002/

22. Marshall J. The Blue Light Paradox: Problem or Panacea. Mivision: Bringing Optics into Focus, 2017. Available at: https://www.mivision.com.au/the-blue-light-paradox-problemor-panacea (12.08.2017).

23. Oliver P.D., Newsom D.A. Mitochondrial Superoxide Dismutase in Mature and Developing Human Retinal Pigment Epithelium. Investigative Ophthalmology \& Visual Science, 1992, vol. 33, no. 6, pp. 1909-1918.

24. Jung S.-K., Lee J.H., Kakizaki H., Jee D. Prevalence of Myopia and its Association with Body Stature and Educational Level in 19-Year-Old Male Conscripts in Seoul, South Korea. Invest. Ophthalmol. Vis. Sci., 2012, vol. 53, no. 9, pp. 5579-5583. DOI: 10.1167/iovs.1210106. 
25. Greenberg J.P., Duncker T., Woods R.L., Smith R.T., Sparrow J.R., Delori F.C. Quantitative Fundus Autofluorescence in Healthy Eyes. Investigative Ophthalmology \& Visual Science, 2013, vol. 54, no. 8, pp. 5684-5693. DOI: $10.1167 /$ iovs.13-12445

26. Retina is Vulnerable to Effects of Blue Light. Science Based Health. Available at:http://www.sciencebasedhealth.com/EUREYE-Study-Blue-Light-Exposure-Low-AntioxidantsIncrease-AMD-Risk-W27.aspx (07.07.2017).

27. Justilien V., Pang J.J., Renganathan K., Zhan X., Crabb J.W., Kim S.R., [et al]. SOD2 knockdown mouse model of early AMD. Investigative Ophthalmology \& Visual Science, 2007, vol. 48, pp. 4407-4420.

28. Kasahara E., Lin L.R., Ho Y.S., Reddy V.N. SOD-2 protects against oxidation-induced apoptosis in mouse retinal pigment epithelium: implications for age-related macular degeneration. Investigative Ophthalmology \& Visual Science, 2005, vol. 46, pp. 3426-3434.

29. Fletcher A.E. [et al]. Sunlight exposure, antioxidants, and age-related macular degeneration. Archives Ophthalmology, 2008, vol. 126, pp. 1396-1403.

30. McCord J.M., Beauchamp C.O., Goscin S., Misra H.P., Fridovich I. Superoxide and superoxide dismutase. Oxidases and Related Redox Systems; In: T.E. King, H.S. Mason, M. Morrison, eds. Baltimore: University Park Press, 1973, vol. 1, pp. 51-76.

31. Villette Th., Lawrenson J. BLUE LIGHT: A review of the evidence on the potential benefits and harms of blue-filtering lenses. London, 2016. Available at: https://www.google.ru/url? $\quad s a=t \& r c t=j \& q=\&$ esrc $=$ s\&source $=-$ web\&cd=1\&ved=0ahUKEwjXuu2y_93XAhWpNpoKHZcrD8AQFggnMAA\&url=https \%3A\% 2F\%2Fwww.college-optometrists.org\%2Fasset\%2F08136AA5-480B-46DE98375A2DD001B8C7\%2F\&usg=AOvVaw3UH48Iykc SdwSfWosX0V7R (10.07.2017).

32. Wing G.L., Blanchard G.C., Weiter J.J. The topography and age relationship of lipofuscin concentration in the retinal pigment epithelium. Invest. Ophthalmol. Vis. Sci., 1978, vol. 17, no. 7, pp. 601-607.

Kaptsov V.A., Deinego V.N. Risks of age related macular degeneration and led lighting. Health Risk Analysis, 2017, no. 4, pp. 129-146. DOI: 10.21668/health.risk/2017.4.14.eng

Received: 31.08 .2017

Accepted: 15.12 .2017

Published: 30.12 .2017 
UDC 613.81

DOI: $10.21668 /$ health.risk/2017.4.15.eng

\title{
ALCOHOL CONSUMPTION AS A FACTOR CAUSING RISKS FOR POPULATION HEALTH (RUSSIAN RESEARCH REVIEW)*
}

\author{
N.A. Lebedeva-Nesevrya ${ }^{1}$, I.G. Zhdanova-Zaplesvichko ${ }^{2}$, V.I. Rerke ${ }^{3}$, A.O. Barg ${ }^{1}$ \\ ${ }^{1}$ Federal Scientific Center for Medical and Preventive Health Risk Management Technologies, 82 Monastyrskaya \\ Str., Perm, 614045, Russian Federation \\ ${ }^{2}$ Federal Service for Surveillance over Consumer Rights protection and Human Well-being, Irkutsk region office, \\ 8 Karla Marksa Str., Irkutsk, 664003, Russian Federation \\ ${ }^{3}$ Irkutsk State University, 1 Karla Marksa Str., Irkutsk, 664003, Russian Federation
}

Our review comprises medical and sociological research conducted over the last 20 years and dedicated to examining reasons and consequences of alcohol consumption in the Russian Federation. We detected that this research covered a wide range of issues starting from analyzing social contexts of alcohol consumption, microsocial, psychological, and biological factors causing alcohol-associated behavior in specific population groups, and then moving on to examining prevalence and gravity of medical and economic consequences which alcohol consumption usually leads to. We dwell on research results which explain reasons for alcohol consumption in various social and age population groups. We also describe different approaches to risk assessment procedure, assessment techniques and criteria applied for characterizing risks. We give concrete data on this bad habit prevalence in a number of the RF regions as well as data on medical-demographic losses caused by alcohol consumption.

It is shown that the issue is recognized at the federal level and a number of political and administrative steps are taken to minimize it. We stress the necessity of closer cooperation between experts, authorities, and population in the process of solving tasks aimed at making our society healthier. We also reveal that risk-communication as a dialogue model is replaced with an information model; and the absence of "feedback" from risk recipients doesn't allow to adequately adjust information flows or to assess their efficiency. In our opinion, the most important task is to build up relevant risk-communications in the society as they will provide searching for most efficient dialogue techniques in the risk-communication system on alcohol addiction reasons and consequences. New riskcommunication technologies should make for better risk awareness among population, above all among young people, as well as for creation of persistent attitude towards giving up alcohol as self-preserving behavior.

Key words: alcohol consumption, population, reasons, health risk, risk assessment, risk-communications, health recovery.

Alcohol abuse is one of the gravest medical and social problems not only in Russia but all over the world. Alcohol holds the third place among risk factors for untimely death, disability, and health loss $[22,58]$. In 2012 DALY index, a parameter which shows aggregate "load with diseases" and which is a linear sum of potential years of life lost due to untimely death and disability, calculated for disorders caused by alcohol abuse, amounted to 32.03 million person-years $(1.2 \%$ of the total load with diseases). The share of economically developed countries (including the Russian Federation) in this value amounts to more than 35\% (11.4 million person-years lost).
For comparison, in 2000 this parameter value was equal to 28.98 million personyears ( $1 \%$ of the total load with diseases) worldwide, and 11.32 million years $(3 \%$ of the total load with diseases) in economically developed countries. For the latter, disorders caused by alcohol abuse are on the seventh place among leading reasons for loss of years due to untimely deaths and disability for people living with a disease or its consequences.

In conformity with "The Russian Federation National Security Strategy for the period up to 2020" approved by the Presidential Order No. 537 on May 12, $2009^{1}$ alcoholism is acknowledged to be a 
threat to the national security in the public healthcare and national health sphere. The significance of this medical and social problem is confirmed by multiple scientific publications which focus on examining impacts exerted on health by alcohol consumption. Thus, target search as per such key words as "alcohol", "consumption", "abuse", "risk", and "health" in titles of papers stored in eLIBRARY.RU scientific elibrary (https://elibrary.ru/) revealed that in 2000-2006 Russian scientists published more than 2,000 works on various issues and aspects related to alcohol consumption and its impacts on somatic, mental, and social health.

Medical research mostly dwells on clinical pictures of alcohol-associated pathologies, and ways how to diagnose and to treat them. Sociological research concentrates on alcohol consumption prevalence in various social groups, among men and women, youth and working population, school children and students, people living in various municipal districts and RF subjects. Experts in the field study life quality dynamics in these groups in relation to alcohol-associated practices as well as social perceptions about alcohol, attitudes towards it and proneness to consume it. Psychological research focuses on analyzing personal peculiarities of individuals who have positive, neutral, on negative attitude towards alcohol, on behavioral consequences of alcohol consumption in various age groups, and on psychological reasons for alcohol consumption.

Our research goal was to systematize and generalize domestic scientific research works published in 2000-2016 and dedicated to alcohol consumption as a health risk factor.

Results and discussion. Problems related to influences exerted by alcohol on individual and population health have traditionally attracted attention not only of Russian medical experts but also of sociologists and psychologists. So, a great number of works have been published in the sphere over the examined period and they are mostly dedicated to analyzing social contexts of alcohol consumption prevalence as well as micro-social, psychological, and biological factors causing alcoholassociated behavior in specific social groups, notably, among young people $[1,7$, 39]. A.V. Golenkov et al. (2009), S.S. Gordeeva (2016) and others pay special attention to social attitudes, standards, and values promoting alcohol consumption prevalence among population as a whole and in specific groups [13, 14]. For example, S.S. Gordeeva states that wide spread of information about alcohol consumption in mass media, hidden beer advertising and hidden advertising of other spirits makes teenagers think that alcohol is truly attractive. This research results correlate well with the data obtained in the course of the examination performed by the Federal State Statistic Service in 2013 and entitled "Sampling observation of behavioral factors influencing population health" ${ }^{2}$ [10]. When asked "Why do you drink alcohol?", 79\% respondents answered it was a tradition to hold celebrations with spirits. Russian teenagers and young people aged 15-19 chose such answers as "a tradition

\footnotetext{
${ }^{1}$ The Russian Federation National Security Strategy for the period up to 2020: The RF President Order No. 537 dated May 12 2009. Available at: http://www.consultant.ru/document/cons doc LAW 87685/ (26.02.2017)

${ }^{2}$ Sampling observation of behavioral factors influencing population health 2013 . Federal State Statistic Service, 2013. Available at: http://www.gks.ru/free_doc/new_site/ZDOR/Sdp2013.Bfs.Publisher/index.html (09.09.2014).
} 
to hold celebrations with spirits" (67\%), "it makes holidays brighter and helps to have a great time" $(29 \%)$, "it helps me to calm down and brings me pleasure" $(15 \%)$, "most people do it" (13\%).

Domestic researchers pay special attention to alcohol consumption models (N.V. Goryacheva, 2003; V.V. Radaev, 2016). They came to conclusion that "strong spirits consumption" pattern dominated in Russia in the early 2000 [15], as well as on transformation of this typical model nowadays and changes in a "several alcohol consumption style", traditional in our country $[36,49]$.

There is also interesting research combining social and medical approaches to analysis of correlation between alcohol and health. Thus, experts from Saratov State Medical University examined influence exerted by various alcohol consumption models on cardiovascular risk evolvement in working population of Saratov and Engels. Cardiovascular risk was shown to go down when a consumption model aimed at low alcohol spirits was implemented [35].

Actual medical research works focusing on examining alcohol consumption as a health risk factor can be divided into four groups.

The first group comprises works devoted to determining and proving correlations between alcohol consumption and negative effects (responses) from health on an individual level. Thus, M.V. Markina in her works (2016) states that alcohol consumption is one of the basic causes for psychoneurological disorders [32], V.O. Generalov et al. (2009), and M. Leone at al. (2012) consider it one of the basic causes for epilepsy $[11,28]$. There are works describing a significant role alcohol plays in evolvement of some non-infectious diseases, for example, cardiovascular ones $[12,37,50]$, and liver cirrhosis [2, 24]. Sanitary-Epidemiologic

Requirements No.1.2.2353-08 "Carcinogenic factors and basic requirements to carcinogenic threats prevention» ${ }^{3}$ enlists alcohol among chemical factors which are hazardous for people and thus stresses alcohol significance as a carcinogenic risk factor. Some researchers rightfully state there is a correlation between some types of cancer and alcohol abuse (I.L. Klyaritskaya, 2007; N.A. Malofeevskaya, 2015; O.V. Reshetnikov at al., 2016 and others.). Thus, there is a positive correlation between alcoholism, alcoholic psychosis and increased morbidity and mortality caused by tumors in the stomach, esophagus, colon, rectum, liver, and lungs [26,31,51].

Research performed in Izhevsk in 2002 revealed that male mortality among working population was to a great extent determined by "hazardous alcohol consumption", notably, non-drinkable alcohol consumption [6].

The second group comprises research on negative influence exerted by alcohol consumption on specific social risk groups which are especially vulnerable, notably, children in perinatal period of their development and newborns [16,54,55].

Influence exerted by a mother's behavioral addiction on a fetus development was examined by Yakut scientists who described alcohol teratogenic effects, intrauterine growth retardation, scull development dismorphism, and irreversible changes in the central nervous system [16, 29,30]. A.B. Palchik and N.P Shabalov et al. $[43,44]$, highlight intrauterine exogenous intoxication as a cause for intrauterine

\footnotetext{
${ }^{3}$ Sanitary-Epidemiologic Requirements 1.2.2353-08. Carcinogenic factors and basic requirements to carcinogenic threats prevention. Available at: http://docs.cntd.ru/document/902101545 (25.07.2016)
} 
teratogenic effects and such their consequences as congenital malformations and minor maldevelopment. Their works are well in line with data obtained in other research, including by foreign experts, where fetal alcohol syndrome is also shown to be a consequence of intrauterine ethanol effects on a fetus. And this syndrome is, among other reasons, a leading one for mental retardation (J.Bertrand,2004; V.I. Shilko et al., 2009; S.M. Zimatkin, 2013) $[21,63,67]$.

Young people (teenagers under 18 and young people aged 18-24) are considered by most scientists to be another population group prone to alcohol addiction evolvement. An issue of alcoholism getting "younger" has been discussed by Russian scientists for a long time (B.A. Ruchkin, 1998) [52]. Research performed in the recent years prove that age of people who systematically drink alcohol has become substantially younger [22]. In 2010 mortality analysis performed on young people revealed that $6 \%$ of overall deaths were caused by psychoactive substances abuse or intoxication, and $5 \%$, by alcohol intoxication [3]. Teenagers and young people are unprotected, first of all, due to medical and psychological age peculiarities of a body and personality development. G.A, Novikova described peculiarities of effects exerted by low alcohol drinks, notably beer, on teenagers and proved there were negative shifts in sensory-motor and psychodynamic processes and changes in functional asymmetry and cerebral biorhythms at various levels of beer alcoholization [39]. A.A. Kirpichenko and I.A. Uvarov showed in their works that systematic alcohol drinking at younger ages, including young females drinking, was one of predisposing factors for alcoholism and tended to turn into chronic alcoholism earlier and faster, apparent alcohol depend- ence and asocial actions, crimes, and lower social status which were usual by-effects of chronic alcoholism [25, 62]. Alcoholism, in addition to all that, causes menstrual cycle disorders and increased risk of unwanted pregnancy for young women [27, 41]. M.S. Ponomareva stated in her work (2013) that damage done by alcohol abuse to young people was twice as high than in case of other age groups. Besides, drunken young people got into car accidents or behaved dangerously more frequently than drunken adults [46].

The third group comprises research related to population health which often deteriorates due to high alcohol consumption prevalence [33, 60, 64]. Authors of such research mostly analyze statistical parameters which characterize population health and calculate economic losses of countries or specific regions caused by health losses associated with alcohol abuse by population. For example, shorter life span in Russian in comparison with most developed countries and high population mortality are closely related to alcohol addiction considered in works by E.M. Andreev, A.A. Korneshov, E.A. Koshkina, A.N. Perezhogin et al. and others $[4,5,6,23,27$, 33]. Experts also dwell on considerable share of overall load with diseases caused by incidental and deliberate injuries, including car accidents (overall number of accidents caused by drunk drivers amounted to 15,344 in 2015, and to 15,669 , in 2016), violence, and suicides [53, 60]. For example, M.Leone and A.Ivashinko stated that "in Russia in 2016 a number of people who committed crimes under alcoholic intoxication amounted to 395.3 thousand people that was $11.5 \%$ higher than in the previous year" [28].

This group of works also includes local (municipal or regional) research [19, $38,47,48,57]$. As a rule, such research 
concentrates on alcohol consumption prevalence or alcohol-associated mortality and morbidity on a specific territory and on highlighting their impacts on this territory economy. For example, research conducted in Irkutsk region $[4,5,18]$ revealed that there was a correlation between alcohol consumption and population health. The authors detected an authentic correlation between alcohol consumption and average life span of Irkutsk region population $(\mathrm{r}=$ $0.5)$, congenital malformations $(\mathrm{r}=0.72), 0$ 1 year old children mortality caused by congenital malformations $(\mathrm{r}=0.71)$, and population mortality caused by accidental alcohol intoxications $(\mathrm{r}=0.8)$. The authors also detected an authentic direct and strong correlation between such a parameter as "population mortality in Irkutsk region caused by accidental alcohol intoxications" (as a parameter characterizing a poor situation with alcohol consumption), and parameters of mortality due to specific nosologies and death causes including injuries and intoxications $(\mathrm{r}=0.94, \mathrm{p}<0.001)$, vascular brain damages $(\mathrm{r}=0.8, \mathrm{p}<0.05)$, and cardiovascular system diseases $(\mathrm{r}=0.8$, $\mathrm{p}<0.05)$. So it was proved that alcoholization level and hazardous consequences related to it was determined by alcohol consumption volumes.

Experts from Murmansk region analyzed statistical parameters and revealed that if mortality caused by alcohol intoxications among population older than 15 increased by 1 case per 100,000 people, then mortality caused by injuries increased by $1.8 \%$ among men and by $1.7 \%$ among women. On average, additional share of mortality caused by injuries and related to alcohol consumption amounts to $24.6 \%$ among men and to $23.4 \%$ among women
[65].

Retrospective analysis of 1,000 morbidity cases with circulatory system diseases in Chuvash Republic conducted in 2000-2010 allowed to prove alcohol abuse was a significant risk factor for such diseases evolvement [66].

Alcohol consumption volume is considered to be one of the most significant factors influencing decrease in average life span and mortality growth among Moscow population [40].

And finally, the fourth group dwells on quantitative predictive estimate of risk associated with alcohol effects on people health [8, 42]. Some research is based on algorithms and risk assessment techniques stated in the methodological Guidelines entitled "Assessment of risk related to impacts exerted by life style factors on population health" (MG 2.1.10.0033-11) ${ }^{4}$. Thus, R.V. Buzinov and T.N. Unguryanu assessed alcohol-associated individual risk for ischemic heart disease (IHD) evolvement among adult population in Arkhangelsk region [9]. They detected than IHD risk related to alcohol consumption among the population living on the examined territory was "alerting" (4.1 E-04) in the age group from 40 to 49 , and "high" in the age group "50 and older" (1.6 E-03 for 50-59 age group and $1.5 \mathrm{E}-02$ for 60 and older). D.M. Shlyapnikov et al. examined workers employed at industrial enterprises and showed that workers who consumed alcohol and who were exposed to industrial factors (the focus group) ran authentically higher risk of digestive organs diseases than workers from the control group [59].

We should note that a number of works concentrating on profound examination of reasons for individual and popula-

${ }^{4}$ MR 2.1.10.0033-11. Assessment of risk related to impacts exerted by life style factors on population health. Available at: http://36.rospotrebnadzor.ru/documents/rekdoc1/9539 (20.04.2017) 
tion alcoholism and on ways how to minimize risks for society alcoholization is substantially lower than a number of research works dwelling on the phenomenon itself (that is, experts examine "alcoholism as a reason and risk factor..." but not "reasons and risk factors which cause alcoholism").

Overall, researchers state that alcoholism results from destruction of a family as a social institution and old habit of domestic hard drinking which is considered to be "harmless". A.V. Merinov (2010)[34], A.V. Nemtsov (2008) [38], and M.V. Pastukhova (2010) [45] state that domestic hard drinking and stressful situation in a family are risk factors causing alcoholism evolvement among teenagers and children. Some researchers mention that alcoholism results from poor leisure culture which young people have [57]. N.V. Romanova et al. (2008) note that a certain "negative contribution is made by modern literature, mostly translated one, which, together with cinema, praises those who are being relaxed and have free-thinking but such behavior turns out to be just permissiveness..." [56]. A. Yu, Efremov and L.A. Kazaryan showed that alcoholism prevalence was promoted by social insecurity, loss of life goals by young people, their value disorientation, and their life being meaningless [17].

A.Yu. Bushkova (2013) also gives some well-grounded reasons for alcoholism. Examining historical roots of alcoholism in Russia, she cites baron Ginzburg, an owner of large industrial enterprises, who said, "I get more gold from vodka deliveries to state wine stores and from industrial distillation than from all my gold mines ... state sales of hard drinks should be preserved at any costs and it should be somehow justified in public opinion's eyes... ". The author also reminds that the country rulers in 90ties last century strove to in- crease state budget earning by alcohol sales growth and privatization of alcoholproducing plants, and it caused drastic increase in population alcoholization [10].

The state officials nowadays fully understand the problem is serious and they take on the responsibility for finding solutions; so legislative and administrative measures are taken to achieve decrease in the country population alcoholization. In recent years, punishments for drunk driving have become substantially harder; alcohol products advertising has been prohibited; struggle against counterfeit products has also intensified as the country budget has lost more than 31 billion rubles due to them. The state continues to develop and implement anti-alcohol policy [61]. In 2015 The Unified State Automated Information System was implemented into wholesale and retail alcohol trade as one of a key measures aimed at alcohol market stabilization. Extrajudicial blocking of web-sites which sell alcohol illegally is now permitted. The government issued a decree allowing to destroy all the production equipment right there where alcohol was illegally manufactured. However, such measures require active support by the civil society. In relation to that, we see healthy life-style propaganda and promotion as one of the most significant trends in minimization of alcohol-associated demographic losses (death cases, disability, and morbidity). But it undoubtedly requires search for new types and techniques of riskcommunications. Alcohol products variety is constantly growing, trade barriers are being removed, state surveillance and control functions are becoming more liberal, and other social-economic processes are developing, and it all calls for transfer to a new paradigm for discussing health risks caused by alcohol consumption (riskcommunications). 
Strategically a risk-communication means a special interaction between "all the involved parties" (risk manufactures and risk consumers, as well as mediators) concerning a risk and this interaction should be based on openness, trust, and equality. Decision-making in risk management sphere and plans how to implement all the taken decisions are to be developed and performed by experts, authorities, and the society together. Solutions to these tasks involve clear perception that a risk is not exceptionally an objective and cognizable fact; it is always mediated by social and cultural stereotypes and processes [20].

At present, this model is often replaced by its "prototype" and we have simple informing instead of a true riskcommunication. And here absence of a feedback from risk recipients doesn't allow to adjust information flows correctly or to assess how efficient they are. Sociological questioning conducted in the RF usually prove these hypotheses. Consequently, we have to face risk underestimation by consumers. Risk-communication issues and attempts to find new ways and techniques are being discussed by the country scientific society, however, foreign research works on the topic have much larger scales and are much more diverse.

A way to build an efficient multi-sided communication system on alcohol evolvement risks and its consequences is to increase information activity of the population and to raise their interest in safety matters; to achieve not only high population awareness about risks but also to create persistent attitudes towards self-preserving behavior; to improve the state system of risk-communications in the population health sphere. It is greatly important to fully use information spread channels which are in demand among a target audience (for example, active social media incorporation), to create conditions for public discussions about risks. A tactic task is to provide methodical support for all the concerned parties in terms of ways and media applied for presenting data on health risks; these ways and media should be relevant for a specific target audience. Another significant way to increase riskcommunications efficiency is more active involvement of the experts society into a constructive discussion about risks. As population tends to trust experts, scientists, or doctors more than they trust public authorities, representatives from these groups are to play their important social role in an efficient data exchange system.

Conclusions. Contemporary research works on alcohol consumption as a health risk factor are numerous and diverse. There are medical examinations dwelling on analyzing "factor - response" relationships (where alcohol consumption is a factor, and a somatic or a mental pathology is a health response); but there are also works which concentrate on micro-social, socialdemographic and socio-cultural consequences of alcohol consumption at a country, regional, or a local level, or on a contribution which alcohol makes into "social ill-being" of a person and a nation as a whole.

A specific research field is where experts deal with alcohol consumption factors which have biological, psychological, or social nature, as well as with alcohol consumption models in various age, ethnic, territorial, and other groups. Methodological issues related to assessing risks associated with alcohol consumption impacts on population health are being discussed in Russian scientific publications: experts describe different approaches to risk assessment procedure implementation, risk assessment techniques, and risk assessment 
criteria. At the same time, suggested theoretical and methodological approaches still don't find sufficient practice implementation. It partially happens due to weak integration of actual results obtained in examining correlations between alcohol consumption and health into the existing techniques for assessing alcohol-associated risks.

Examination of most efficient tech- niques in a risk-communication dialogue system devoted to reasons and consequences of alcohol addiction in the society should become a separate important trend in scientific research in the field, together with searching for new ways and techniques aimed at supporting "selfpreserving" and "low-risk" behavior among young people.

\section{References}

1. Aleinikova T.V. Predstavleniya o vozrastnoi periodizatsii ontogeneza cheloveka [Views on age periodization of human ontogenesis].Vozrastnaya psikhofiziologiya. Moscow, Feniks, Publ., 2007, Chapter1, pp. 5-10 (in Russian).

2. Alkogol'naya bolezn' pecheni i alkogolizm - dve bolezni i odna problema / A.A. Samsonov, E.Yu. Plotnikova, I.N. Nikushkina, E.A. Talitskaya, M.V. Krasnova, O.A. Krasnov [Alcoholic liver disease and alcoholism: two diseases, one problem]. Meditsinskii sovet, 2013, no. 10, pp. 38-41(in Russian).

3. Al'bitskii V.Yu., Ivanova A.E., Il'in A.G. Smertnost' podrostkov v Rossiiskoi Federatsii [Teenagers mortality on the Russian Federation]. Moscow, 2010, 61 p. (in Russian).

4. Perezhogin A.N., Luzhnov M.V., Zhdanova-Zaplesvichko I.G., Dubrovina O.A., Tarbeeva E.A., Kuz'mina M.V., Shpakova N.L. Analiz dinamiki zabolevaemosti khronicheskim alkogolizmom, alkogol'nymi psikhozami i narkomaniei v Irkutskoi oblasti: Informatsionno-analiticheskii byulleten' za 2014 god [Analysis of mortality from chronic alcoholism, alcoholic psychosis, and drug addiction in Irkutsk region: Information-analytical bulletin for 2014]. Irkutsk, 2015, 26 p. (in Russian).

5. Perezhogin A.N., Luzhnov M.V., Zhdanova-Zaplesvichko I.G., Zaikova Z.A., Bas'ko E.V., Tarbeeva E.A. Analiz dinamiki zabolevaemosti khronicheskim alkogolizmom, alkogol'nymi psikhozami i narkomaniei v Irkutskoi oblasti v 2013 g.[ Analysis of mortality from chronic alcoholism, alcoholic psychosis, and drug addiction in Irkutsk region in 2014]. Irkutsk, 2014, 48 p. (in Russian).

6. Andreev E.M. Vozmozhnye prichiny kolebanii prodolzhitel'nosti zhizni v Rossii v 90-e gg. [Possible reasons for fluctuations in life interval in Russia in 90-ies last century]. Voprosy statistiki, 2002, no. 11, pp. 3-15 (inRussian).

7. Bezrukikh M.M., Dubrovinskaya N.V., Farber D.A. Psikhofiziologiya rebenka [A child psychophysiology]. Moscow, MPSI, Publ., 2008, 495 p. (in Russian).

8. Belikova M.Sh., Zakharova M.A., Sartakov P.G. Otsenka riska, svyazannogo s vozdeistviem tabakokureniya i alkogolya, dlya zdorov'ya kursantov voennogo instituta i metodika profilaktiki [Assessment of risk associated with exposure to tobacco and alcohol on health of the cadets of military institute and its prevention methodology]. Analiz riska zdorov'yu, 2015, no. 2, pp. 24-30.DOI: 10.21668/health.risk/2015.2.03.eng. 
9. Buzinov R.V., Unguryanu T.N. Otsenka riska, svyazannogo s povedencheskimi faktorami obraza zhizni [An assessment of the risk associated with behavioral lifestyle factors]. Analiz riska zdorov'yu, 2013, no. 2, pp. 45-48. DOI: 10.21668/health.risk/2013.2.05.eng.

10. Bushkova A.Yu. Sotsial'no-politicheskie prichiny i posledstviya alkogolizma v Rossii [Social and political reasons and consequences of alcoholism in Russia]. Molodezhnyi nauchno-tekhnicheskii vestnik, 2013, no. 4, pp. 44-50 (in Russian).

11. Generalov V.O., Sadykov T.R. Alkogol'naya epilepsiya [Alcoholic epilepsy]. Zdorov'e - osnova chelovecheskogo potentsiala: problemy i puti ikh resheniya, 2009, vol. 4, no. 1, pp. 12-13 (in Russian).

12. Gertsen M.A., Kozlov I.D. Svyaz' upotrebleniya alkogolya so smertnost'yu ot serdechno-sosudistykh zabolevanii u muzhchin s ishemicheskoi bolezn'yu serdtsa: rezul'taty 25-letnego prospektivnogo nablyudeniya [A correlation between alcohol consumption and mortality caused by cardiovascular diseases in men with ischemic heart disease: results of 25-year prospective observation]. Kardiovaskulyarnaya terapiya i profilaktika, 2008, vol. 7, no. 6S1, pp. 88. - S. 88 (in Russian).

13. Golenkov A.V., Andreeva A.P., Bulygina I.E. Chastotno-kolichestvennye pokazateli i motivy potrebleniya alkogol'nykh napitkov studentami-medikami [Quantitative and qualitative measures and motives for alcohol use in medical students]. Narkologiya, 2009, vol. 8, no. 10, pp. 25-29 (in Russian).

14. Gordeeva S.S. Sotsiologicheskii analiz funktsii ustanovki na potreblenie alkogolya u podrostkov [Sociological analysis of set function for alcohol consumption by teenagers]. Diskussiya, 2016, no. 6 (69), pp. 57-63 (in Russian).

15. Goryacheva N.V. Model' potrebleniya alkogolya v Rossii [A model of alcohol consumption in Russia]. Sotsiologicheskii zhurnal, 2003, no. 4, pp. 101-107 (in Russian).

16. Kershengol'ts B.M., Chernobrovkina T.V., Nebrat V.V., Rabinovich E.V., Khlebnyi E.S., Shein A.A., Kershengol'ts E.B. Deistvievodnospirtovykhsistemnadissipativnyesostoyaniyacheloveka. Gipoteticheskaya model' biogennosti i narkogennosti spirtsoderzhashchikh produktov [Impacts exerted by water-alcoholic systems on a human dissipative state. A hypothetical mode; of biogenicity and narcogenic potential of alcohol-containing substances]. Narkologiya, 2004, no. 8, pp. 64-76 (in Russian).

17. Efremov A.Yu., Kazaryan L.A. Sotsial'no-psikhologicheskie aspekty prichin podrostkovogo alkogolizma [Social and psychological aspects of reasons for teenagers alcoholism]. Vospitanie $i$ obuchenie: teoriya, metodika $i$ praktika: sbornik materialov VI Mezhdunarodnoi nauchno-prakticheskoi konferentsii [Education and teaching: theory, methodology and practice: materials of the VI International theory and practical conference]. 2016, pp. 57-59 (in Russian).

18. Zhdanova-Zaplesvichko I.G., Zaikova Z.A. Analiz meditsinskikh i sotsial'noekonomicheskikh posledstvii potrebleniya alkogolya, tabaka i narkotikov v Irkutskoi oblasti [Analysis of medical and social-economic consequences of alcohol, tobacco, and drugs consumption in Irkutsk region]. Metodologiya profilakticheskoi meditsiny i formirovaniya zdorovogo obraza zhizni: Sbornik nauchnykh statei [Prevention medicine methodology and healthy life-style formation: Scientific papers collection]. In: A.E. Agapitov, ed. Irkutsk, RIOGBOUDPOIGMAPO, Publ., 2012, pp. 15-18 (in Russian).

19. Bukin V.N., Terkulov R.I., Kormilina O.M., Shamsutdinov Ya.V., Sosnina V.S. Zabolevaemost' naseleniya Novosibirskoi oblasti narkologicheskimi rasstroistvami v $2010 \mathrm{~g}$. 
[The Novosibirsk region population morbidity of narcology diseases in 2010 year]. Narkologiya, 2011, vol. 10, no. 7, pp. 57-60 (in Russian).

20. Zaitseva N.V., Lebedeva-Nesevrya N.A. Podkhody k postroeniyu effektivnoi regional'noi sistemy informirovaniya o riskakh zdorov'yu [Methodological approaches to building of regional system of health risks information]. Zdorov'esem'i- 21 vek, 2010, no. 4, pp. 8 (in Russian).

21. Zimatkin S.M., Bon' E.I. Fetal'nyi alkogol'nyi sindrom: povedencheskie i nevrologicheskie narusheniya [Fetal alcohol syndrome: behavioral and neurological disorders]. Zhurnal Grodnenskogo gosudarstvennogo meditsinskogo universiteta, 2013, vol. 42, no. 2, pp. 14-17(in Russian).

22. Zloupotreblenie alkogolem v Rossiiskoi Federatsii: sotsial'no-ekonomicheskie posledstviya i mery protivodeistviya: Doklad Soveta Obshchestvennoi palaty RF ot 13 maya 2009 g. [Alcohol abuse in the Russian Federation: social-economic consequences and resistance to it: A report made by the RF Civic Chamber Council on May 13, 2009]. Moscow, 2009, 84 p. (in Russian).

23. Andreev E.M., Kir'yanov N.A., Leon D., Makki M., Tomkins S., Shkol'nikov V.M. Zloupotreblenie alkogolem i prezhdevremennaya smertnost' v Rossii na primere Izhevska [Hazardous alcohol drinking and premature mortality in russia: a population based case-control study]. Narkologiya, 2008, vol. 7, no. 7, pp. 38-52 (in Russian).

24. Zloupotreblenie psikhoaktivnymi veshchestvami [Management of substance abuse]. World Health Organization. Available at: http://www.who.int/substance abuse/facts/alcohol/ru/ (26.02.2017) (in Russian).

25. Kirpichenko A.A. Alkogol'naya zavisimost' u zhenshchin s razlichnymi formami sotsial'nogo funktsionirovaniya: avtoref. dis. ... d-ra med.nauk [Alcohol addiction in females with various social functions: abstracts of the thesis. ... for Doctor of Medical Sciences]. Moscow, 2008, 34 p. Available at: http://www.dissercat.com/content/alkogolnayazavisimost-u-zhenshchin-s-razlichnymi-formami-sotsialnogo-funktsionirovaniya (21.04.2016) (in Russian).

26. Klyaritskaya I.L., Is'kova I.A. Rol' alkogolya v vozniknovenii raka zheludochnokishechnogo trakta [Role of alcohol in occurrence of a cancer of a gastrointestinal tract]. Krymskii terapevticheskii zhurnal, 2007, vol. 2, no. 2 (9), pp. 18-23 (in Russian).

27. Korneshov A.A. Sovremennyi obraz zhizni naseleniya, kak faktor razrusheniya demograficheskogo potentsiala Rossii: avtoref. dis. ... d-ra ekonomich. nauk [Contemporary population lifestyle as a factor causing destruction of the RF demographic potential: abstracts of the thesis. ... for Doctor of Economics]. Moscow, 2010, 45 p. (in Russian).

28. Leone M., Ivashinko A. Epilepticheskie pripadki i alkogol' [Epileptic seizures and alcohol]. Nevrologiya i neirokhirurgiya Vostochnaya Evropa, 2012, no. 1, pp. 109-132 (in Russian).

29. Malakhova Zh.L. Kliniko-patogeneticheskie osnovy fetal'nogo alkogol'nogo sindroma $u$ detei rannego vozrasta: avtoref. dis. ... d-ra med nauk [Clinical and pathogenetical grounds for fetal alcohol syndrome in infants: abstracts of the thesis. ... for Doctor of Medical Sciences]. Ekaterinburg, 2012, 47 p. (in Russian).

30. Malakhova Zh.L., ShilkoV.I., Shukshina L.A. Fetal'nyi alkogol'nyi spektr narushenii sredi vospitannikov sotsial'nykh uchrezhdenii [Fetal alcohol disorders among the inmates of social institutions]. Kazanskii meditsinskii zhurnal, 2009, no. 5, pp. 647-650 (in Russian). 
31. Malofeevskaya N.A. Zlokachestvennye obrazovaniya: vliyanie upotrebleniya alkogolya i ego posledstvii [Cancer: the impact of alcohol consumption and its consequences]. Upravlenie megapolisom, 2015, vol. 2, no. 6 (48), pp. 97-103(in Russian).

32. Markina M.V. Nevrologicheskie rasstroistva pri khronicheskom alkogolizme [Neurological disorders associated with chronic alcoholism]. Tsentral'nyi nauchnyi vestnik, 2016, vol. 1, no. 13, pp. 24-26 (in Russian).

33. Koshkina E.A., Pavlovskaya N.I., Yagudina R.I., Kulikov A.Yu., Usenko K.Yu. Mediko-sotsial'nye i ekonomicheskie posledstviya zloupotrebleniya alkogolem v Rossiiskoi Federatsii [Health and social and also economic consequences of alcohol abuse in the Russian Federation]. Sotsial'nye aspekty zdorov'ya naseleniya: elektronnyi nauchnyi zhurnal, 2010, no. 2 (14). Available at: http://vestnik.mednet.ru/content/view/189/30/lang,ru/ (11.04.2014) (in Russian).

34. Merinov A.V., Shustov D.I. Autoagressiya v sem'yakh bol'nykh alkogolizmom [Autoaggression in alcoholics' families]. Narkologiya, 2010, vol. 9, no. 9, pp. 26-30 (in Russian).

35. Malinova L.I., Furman N.V., Klochkov V.A., Dolotovskaya P.V., Podbolotov R.A. Model' potrebleniya alkogolya $\mathrm{i}$ obshchii serdechno-sosudistyi risk u lits trudosposobnogo vozrasta [Alcohol drinking pattern and total cardiovascular risk in able-bodied people]. Profilakticheskaya meditsina, 2015, vol. 18, no. 3, pp. 24-30 (in Russian).

36. Nemtsov A.V. Alkogolizm v Rossii: istoriyavoprosa, sovremennye tendentsii [A1coholism in Russia: history and contemporary trends]. Zhurnal nevrologii i psikhiatrii im. C.C. Korsakova, 2007, vol. 107, no. S1, pp. 3-7 (in Russian).

37. Nemtsov A.V., Terekhin A.T. Cvyazannaya s alkogolem serdechno-sosudistaya smertnost'

[Alcohol-associated cardiovascular mortality in Russia]. Profilakticheskaya meditsina, 2008, vol. 11, no. 2, pp. 23-31 (in Russian).

38. Nemtsov A.V., Shelygin K.V. Zavisimye ot alkogolya yavleniya. Situatsiya v severo-zapadnom federal'nom okruge [Alcohol related issues. Situation in the NorthWestern Federal District]. Narkologiya, 2009, vol. 8, no. 12, pp. 44-52 (in Russian).

39. Novikova G.A. Psikhofiziologicheskie osobennosti podrostkov v zavisimosti ot intensivnosti pivnoi alkogolizatsii: avtoref. dis. ... kand. biol. Nauk [Psychophysiological peculiarities of teenagers depending on beer alcoholization intensity: abstracts of the thesis. ... for Candidate of Biological Sciences]. Arkhangel'sk, 2009, 18 p. (in Russian).

40. Novoselova E.N. Osnovnye faktory prodolzhitel'nosti zhizni zhitelei megapolisa (na primere Moskvy) [Main factors of megalopolis citizens' life expectancy (example of Moscow)]. Vestnik Moskovskogo universiteta. Seriya 18: Sotsiologiya i politologiya, 2016, vol. 22, no. 2, pp. 176-200 (in Russian).

41. Osmanov E.M., Pyshkina A.S. Vliyanie alkogolya na reproduktivnoe zdorov'e zhenshchin [Influence exerted by alcohol on female reproductive health]. Vestnik Tambovskogo universiteta. Seriya: Estestvennye i tekhnicheskie nauki, 2010, vol. 15, no. 1, pp. 59-62 (in Russian).

42. Indutnyi A.V., Novikov D.G., Khodosevich A.A., Gorbunova L.V., Borzenok G.A., Trofimovich N.A. Otsenka kardiovaskulyarnogo riska pri razlichnom urovne potrebleniya alkogolya [Cardiovascular risk assessment in patients with different level of alcohol consumption]. Sovremennye problemy nauki i obrazovaniya, 2016, no. 2, pp. 146 (in Russian). 
43. Pal'chik A.B., Fedorova L.A., Legon'kova C.B. Fetal'nyi alkogol'nyi sindrom: metodicheskie rekomendatsii [Fetal alcohol syndrome: methodical guidelines]. St. Petersburg, 2006, pp. 1-24 (in Russian).

44. Pal'chik A.B., Shabalov N.P. Toksicheskie entsefalopatii novorozhdennykh [Toxic encephalopathy in newborns]. Moscow, MEDpressinform, Publ., 2009, pp. 12-56 (in Russian).

45. Pastukhova M.V. Problema razvitiya i vospitaniya rebenka v sem'e pri alkogolizme ottsa [An issue of developing and educating a child in a family with an alcohol-dependent father]. Prikladnaya psikhologiya i psikhoanaliz, 2010, no. 2, pp. 4 (in Russian).

46. Ponomareva M.S. Zloupotreblenie alkogolem molodymi lyud'mi kak ugroza natsional'noi bezopasnosti Rossii [Alcohol abuse among young people as a threat to the RF national security]. Natsional'nye interesy: prioritety $i$ bezopasnost', 2013, no. 7, pp. 52-63 (in Russian).

47. Pochitaeva I.P., Golubeva A.P. Sotsial'no-epidemiologicheskaya kharakteristika alkogol'nykh rasstroistv v Kostromskoi oblasti [Social and epidemiological characteristics of alcohol use disorders in the Kostroma region]. Kazanskii meditsinskii zhurnal, 2014, vol. 95, no. 3, pp. 426-433 (in Russian).

48. Izergina E.V., Lozovskaya S.A., Kosolapov A.B., Shevtsova S.P. Predotvratimaya smertnost' muzhskogo naseleniya Dal'nevostochnogo Federal'nogo okruga Rossii [Preventable mortality of the male population of the far Eastern Federal District of Russia]. Fundamental'nye issledovaniya, 2015, no. 1-9, pp. 1836-1841 (in Russian).

49. Radaev V.V., Kotel'nikova Z.V. Izmenenie struktury potrebleniya alkogolya v kontekste gosudarstvennoi alkogol'noi politiki v Rossii [Changes in alcohol consumption structure within the context of the state alcohol politics in the RF]. Ekonomicheskaya politi$k a, 2016$, vol. 11, no. 5, pp. 92-117(inRussian).

50. Razvodovskii Yu.E. Alkogol' kak faktor riska serdechno-sosudistoi smertnosti [Alcohol as a risk factor of cardiovascular mortality]. Narkologiya, 2013, vol. 12, no. 2 (134), pp. 38-42 (in Russian).

51. Reshetnikov O.V., T Openko.G., Kurilovich S.A., Khryanin A.A., Malyutina S.K. Rak pecheni i ego faktory riska $\mathrm{v}$ Novosibirske [Hepatic cancer and its risk factors in novosibirsk]. Sibirskii onkologicheskii zhurnal, 2016, vol. 15, no. 3, pp. 19-27 (in Russian).

52. Ruchkin B.A. Molodezh' i stanovlenie novoi Rossii [Youth and formation of a new Russia]. Sotsiologicheskie issledovaniya, 1998, no. 5, pp. 90-98 (in Russian).

53. Sakharov A.V., Govorin N.V. Suitsidal'noe povedenie i potreblenie alkogolya: otsenka vzaimosvyazei na populyatsionnom urovne [Suicidal behavior and alcohol: estimation of correlations at the population level]. Suitsidologiya, 2015, vol.6, no. 2, pp. 35-46 (in Russian).

54. Sakharova E.A. Vozdeistvie alkogolya na plod [Alcohol impacts on a fetus]. Problemy sovremennoi meditsiny: aktual'nye voprosy: Sbornik nauchnykh trudov po itogam mezhdunarodnoi nauchno-prakticheskoi konferentsii [Vital issues of contemporary medicine: a collection of scientific papers as per results of an international theory and practical conference]. 2016, pp. 233-236 (in Russian).

55. Sokolovskaya T.A., Azarko V.E., Dmitrieva O.V. Vliyanie alkogolizma roditelei na formirovanie invalidnosti u detei [Influence of parents' alcoholism on formation of physical inability at children]. Sotsial'nye aspekty zdorov'ya naseleniya, 2009, vol. 9, no. 1, pp. 9 (in Russian). 
56. Romanova N.M., Davidson E.M., Kasterina I.A., Voronov S.E. Sotsial'nopsikhologicheskie faktory zhenskoi prestupnosti [Social and psychological factors of female criminality]. Saratov, Izd-vo Saratovskogo Universiteta, Publ., 2008, 80 p. (in Russian).

57. Leshchenko Ya.A., Boeva A.V., Dorogova V.B., Golubev V.Yu. Sotsial'noekologicheskie aspekty zhiznedeyatel'nosti i zdorov'ya naseleniya promyshlennogo goroda Sibiri [Social and economic aspects of population life and health in a Siberian industrial city]. Novosibirsk, 2014, 280 p. (in Russian).

58. Sotsial'no-ekonomicheskoe polozhenie Rossii 2016 [Social and economic situation in Russia in 2016]. Federal'nayasluzhbagosudarstvennoistatistiki (Rosstat). Moscow, 2016, 371 p. Available at: http://www.gks.ru/wps/ $\mathrm{wcm} /$ connect/rosstat_main/rosstat/ru/statistics/publications/catalog/doc_1140086922125 (25.06.2017) (in Russian).

59. Shlyapnikov D.M., Shur P.Z., Ryazanova E.A., Alekseev V.B., Kostarev V.G. Sochetannoe deistvie proizvodstvennykh faktorov i faktorov obraza zhizni na razvitie nekotorykh proizvodstvenno obuslovlennykh zabolevanii $\mathrm{u}$ rabotnikov mashinostroeniya [Combined action of the production factors and lifestyle factors on development of some occupation caused diseases at workers of mechanical engineering]. Izvestiya Samarskogo nauchnogo tsentra Rossiiskoi akademii nauk, 2013, vol. 15, no. 3-6, pp. 2021-2023 (in Russian).

60. Soshnikov S.S. Rol' alkogol'nogo faktora v formirovanii poter' zdorov'ya naseleniya v rezul'tate dorozhno-transportnykh proisshestvii (na primere Moskvy): avtoref. dis. ... kand. med nauk [A role which the alcohol factor plays in population health losses caused by road accidents (on the example of Moscow): abstracts of the thesis. ... for Candidate of Medical Sciences]. Moscow, 2008, 27 p. (in Russian).

61. Soshnikov S.S., Kaigorodova T.V. Strategiya VOZ po bor'be chrezmernym upotrebleniem alkogolya i ee ispol'zovanie pri formirovanii alkogol'noi politiki Rossii [The WHO strategy on fighting alcohol abuse and its application in working out Russian alcohol policy]. Obshchestvennoe zdorov'e i profilaktika zabolevanii, 2006, pp. $42-47$ (in Russian).

62. Uvarov I.A. Epidemiologiya, klinika, techenie i lechenie alkogol'nykh psikhozov): avtoref. dis. ... d-ra med nauk [Epidemiology, clinical course and treatment of alcohol psychosis: abstracts of the thesis. ... for Doctor of Medical Sciences]. Moscow, 2009, 38 p. (in Russian).

63. Shilko V.I., Malakhova Zh.L., Bubnov A.A., Bazarnyi V.V., Klein A.V. Fetal'nyi alkogol'nyi sindrom: kliniko-eksperimental'nye sopostavleniya [Fetal alcohol syndrome: clinical and experimental comparison]. Narkologiya, 2009, vol. 8, no. 8, pp. 38-40 (in Russian).

64. Khalturina D.A., Korotaev A.V. Russkii krest. Faktory, mekhanizmy i puti preodoleniya demograficheskogo krizisa v Rossii [The Russian cross. Factors, mechanisms and ways to overcome a demographic crisis in Russia]. Moscow, URSS, Publ., 2006, 111 p. (in Russian).

65. Shelygin K.V., Lozhkina L.I. Travmaticheskaya smertnost' i potreblenie alkogolya $\mathrm{v}$ Murmanskoi oblasti [Traumatic mortality and alcohol consumption in Murmansk region]. Sotsial'nye aspekty zdorov'ya naseleniya, 2016, vol. 47, no. 1, pp. 4 (in Russian).

66. Shuvalova N.V. Mediko-biologicheskie faktory riska zabolevaemosti boleznyami sistemy krovoobrashcheniya v Chuvashii [Medical and biolog risk factors of blood system 
diseases in the Chuvash republic]. Sovremennye problemy nauki i obrazovaniya, 2012, no. 4, pp. 70 (in Russian).

67. Bertrand J., Floyd R.L., Weber M.K., O’Connor M., Riley E.P., Johnson K.A., Cohen D.E., National Task Force on FAS/FAE. Fetal Alcohol Syndrome: Guidelines for Referral and Diagnosis. Atlanta, GA: Centers for Disease Control and Prevention, 2004, 62 p.

Lebedeva-Nesevrya N.A., Zhdanova-Zaplesvichko I.G., Rerke V.I., Barg A.O. Alcohol consumption as a factor causing risks for population health (Russian research review). Health Risk Analysis, 2017, no. 4, pp. 147-160. DOI: 10.21668/health.risk/2017.4.15.eng

Received: 25.09.2017

Accepted: 11.12 .2017

Published: 30.12 .2017 
